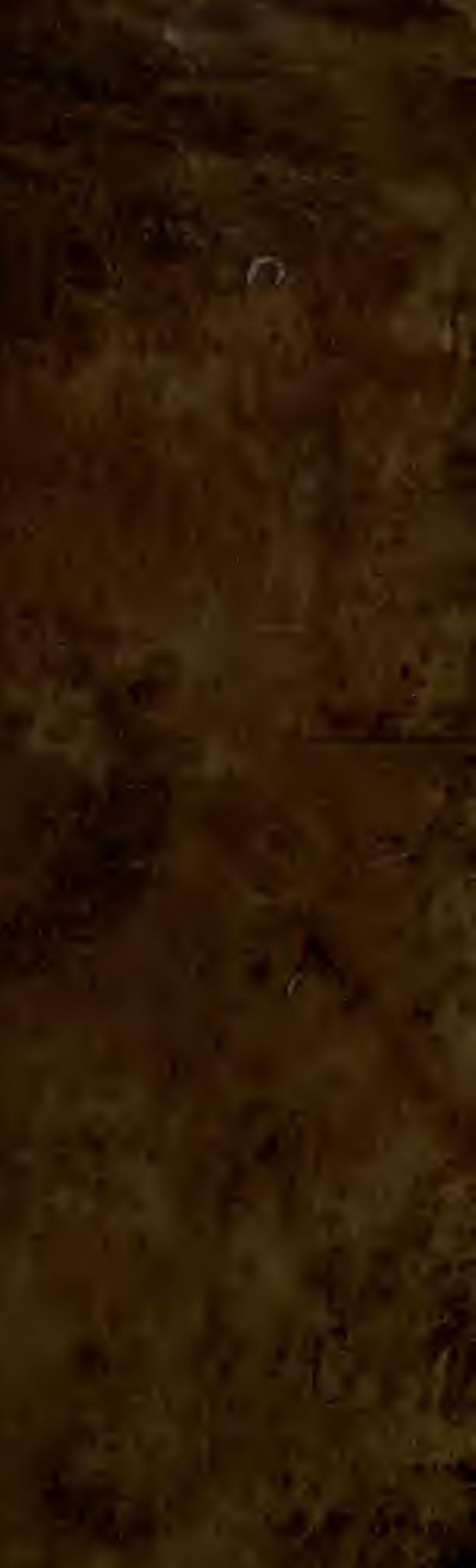




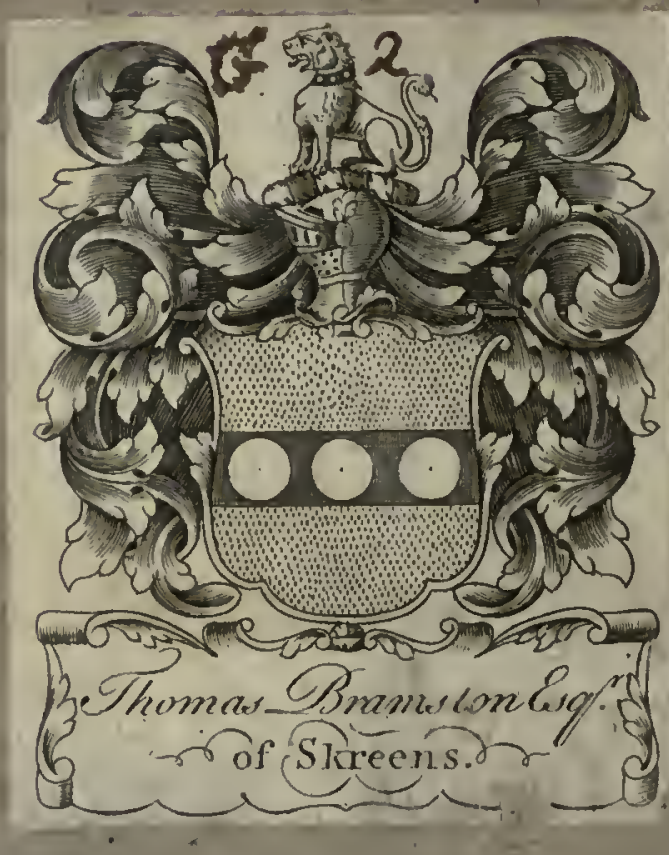

(t)

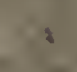




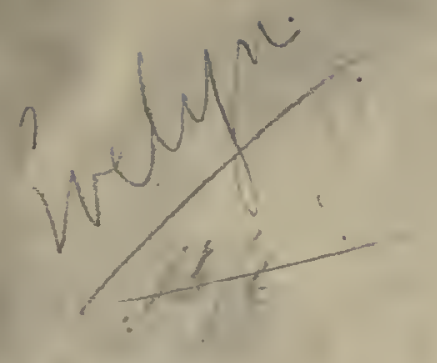

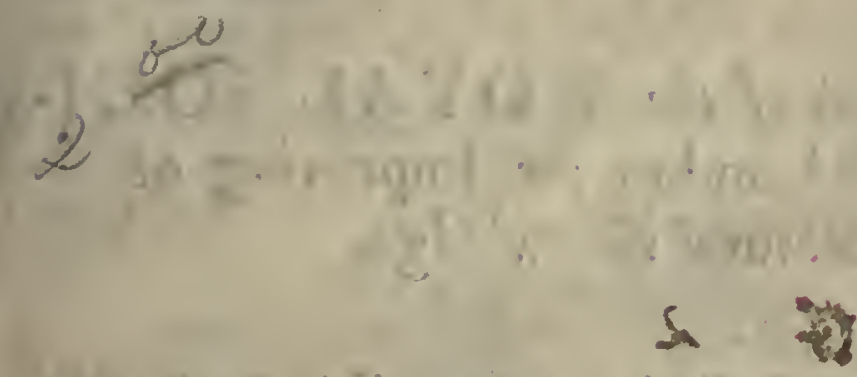

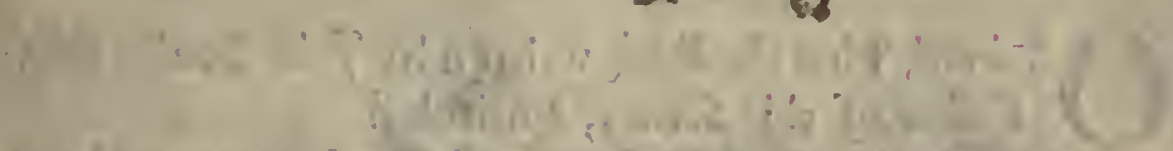

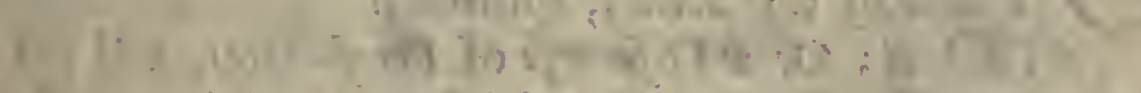

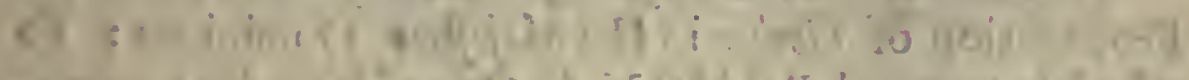

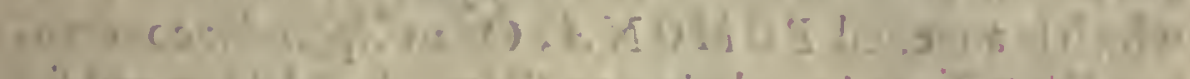

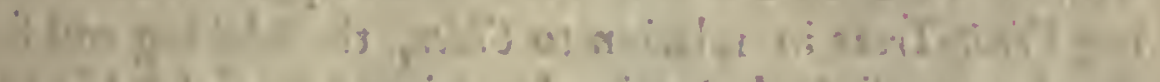

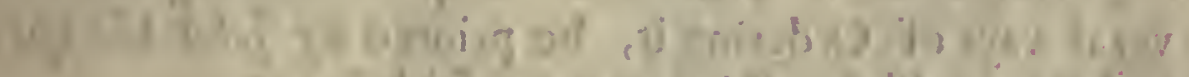

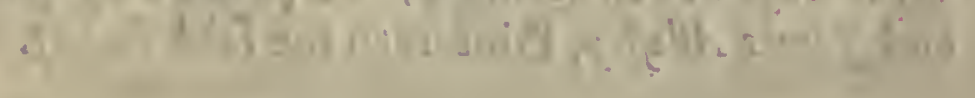

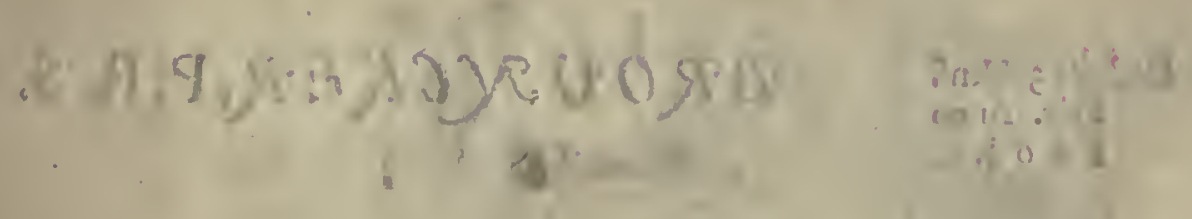


By the Council of the ROYAL SOCIETY of London for Improving of Natural Knowledge.

Rdered, That the Book written by fobn Evelyn Efq; Fellow of this Society, Entitulcd

$S Y L V A$; Or a Difcourfe of Foreft-Trees, and the Propagation of Timber in His Majefties Dominions: To which is annexed POMONA; Or an Appendix concerning Fruit-Trees in relation to Cider, the Making and feveral ways of Ordering it, be printed by Fobn Martyn and 7 ames Alleftry, Printers to the faid Society. 


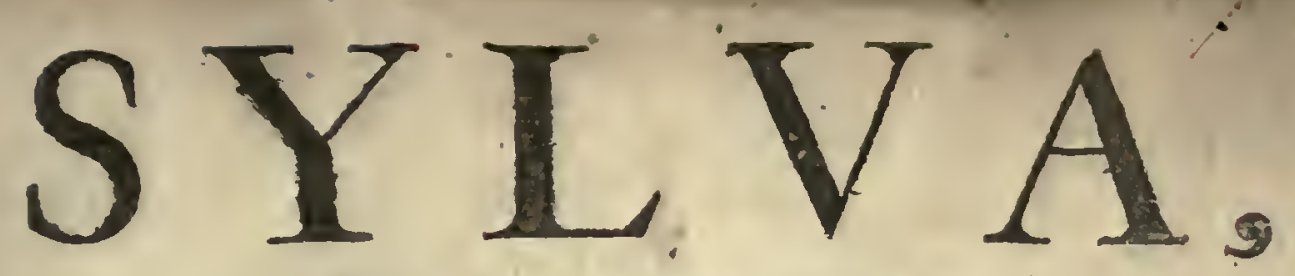

Or A DISCOUIRSE of

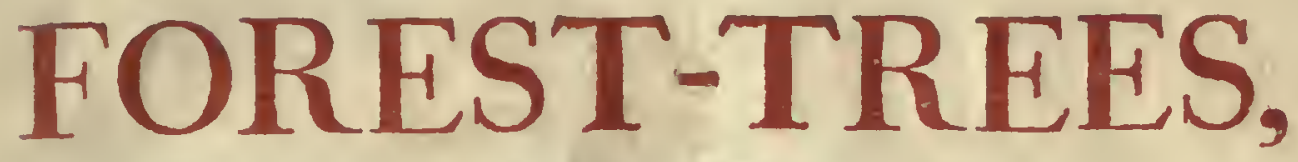

A N D.THE

Propagation of Timber

In His MA JESTIES Dominions.

$$
\text { By } \mathcal{F} \text { : E. Efq; }
$$

As it was Deliver'd in the ROY AL SOCIETY the $\mathrm{xv}^{\text {th }}$ of odtober, CIDIJ CLXII. upon Occafion of certain Quaries

Propounded to that Iliuflious $A \int \mathrm{f} m b l y$, by the Honorable the Principal Officers, and Commiffoners of the Navy.

To which is annexed

POMONA Or,An Appendix concerning Fruit-Trees in relation to CIDER;

The Making and fevcral ways of Ordering it.

Publifhed by exprefs Order of the ROYAL SOCIETY.

A L SO

KALENDARIVM HORTENSE; Or; Gard'ners Almanac

Direting $w$ bat he is to do Monetbly throughout the $\Upsilon_{\text {car }}$.

Ingredior, tantos anfus reciudere fonteis. Virg.

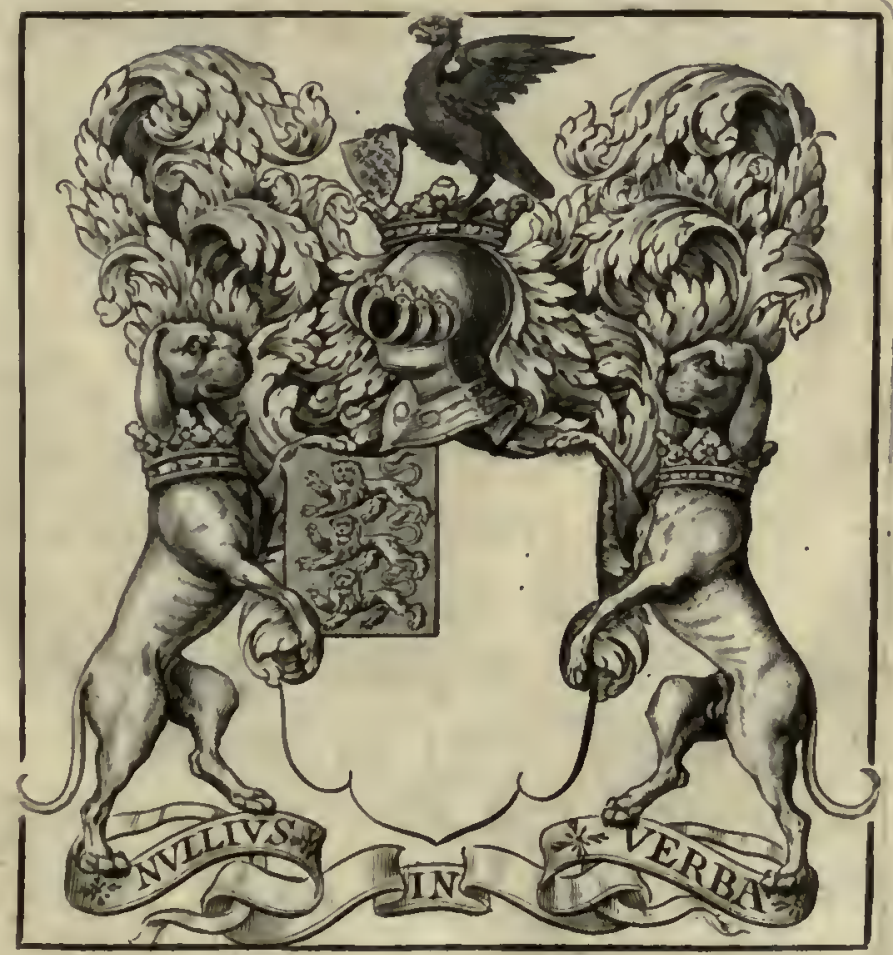

LONDON, Printed by Fo. Martym, and Fa. Allestry, Printers to the Royal Society, and are to be fold at their Shop at the Beth in S. Paul's Church-yard, MDCLXIV. 


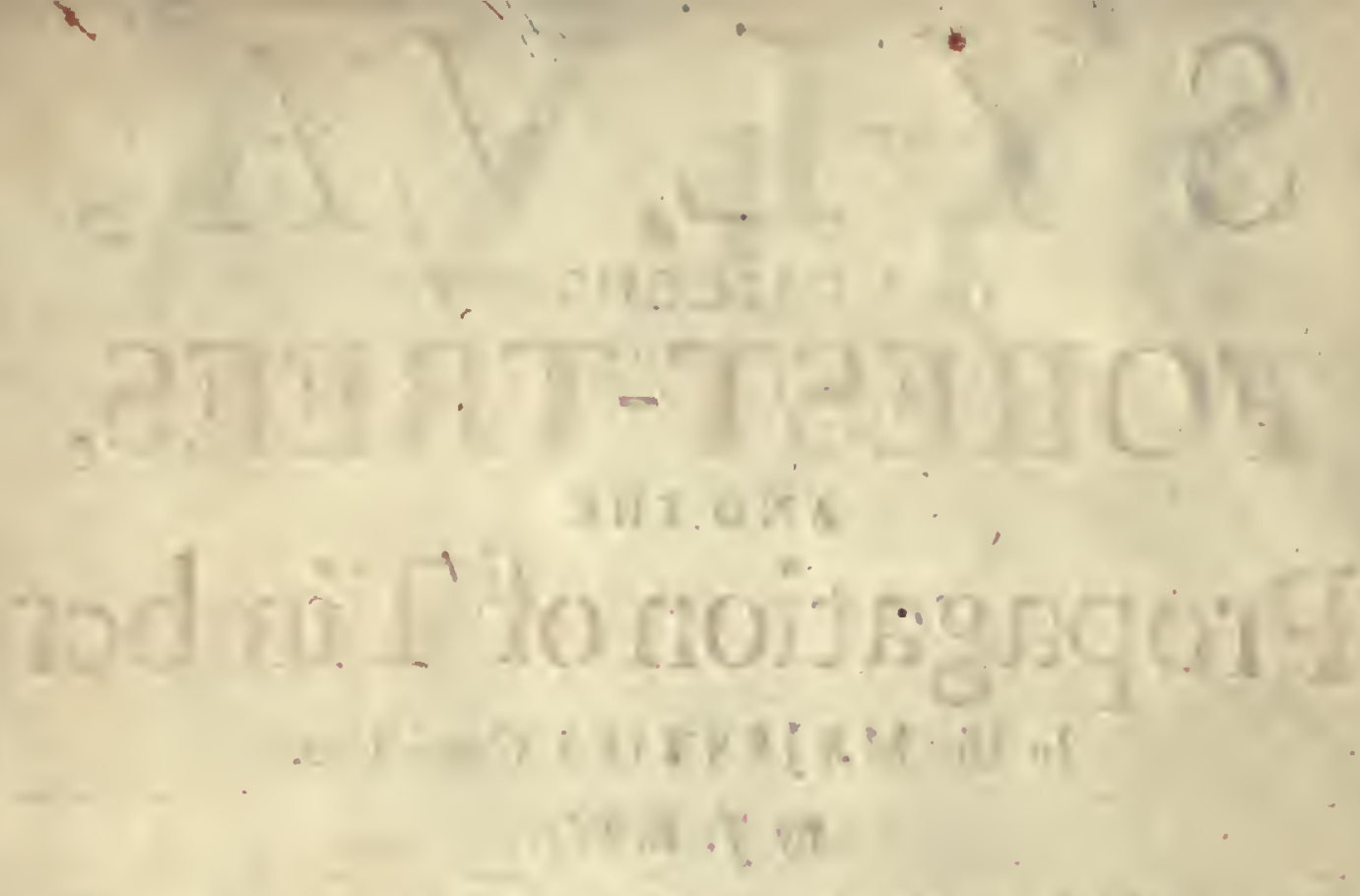

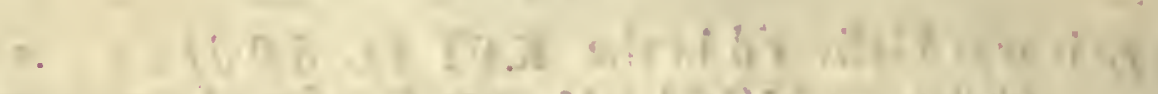

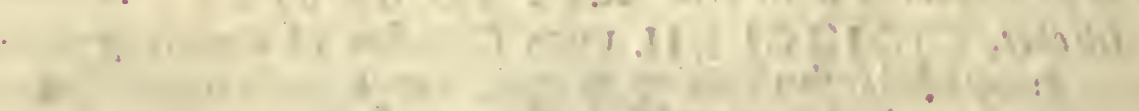

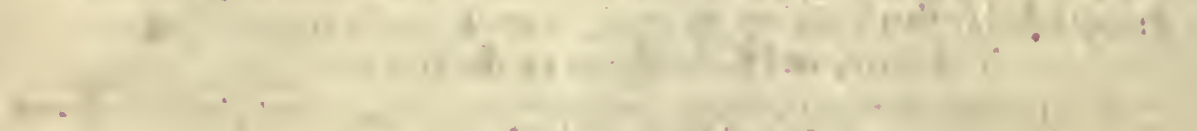

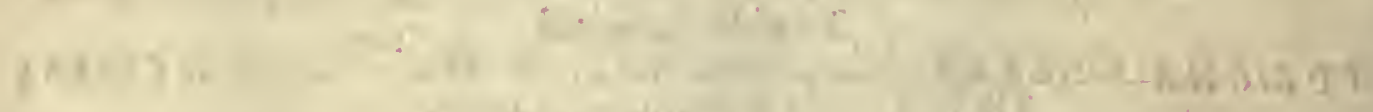

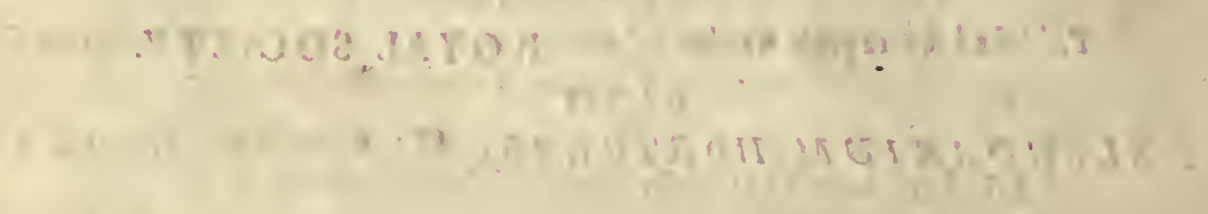

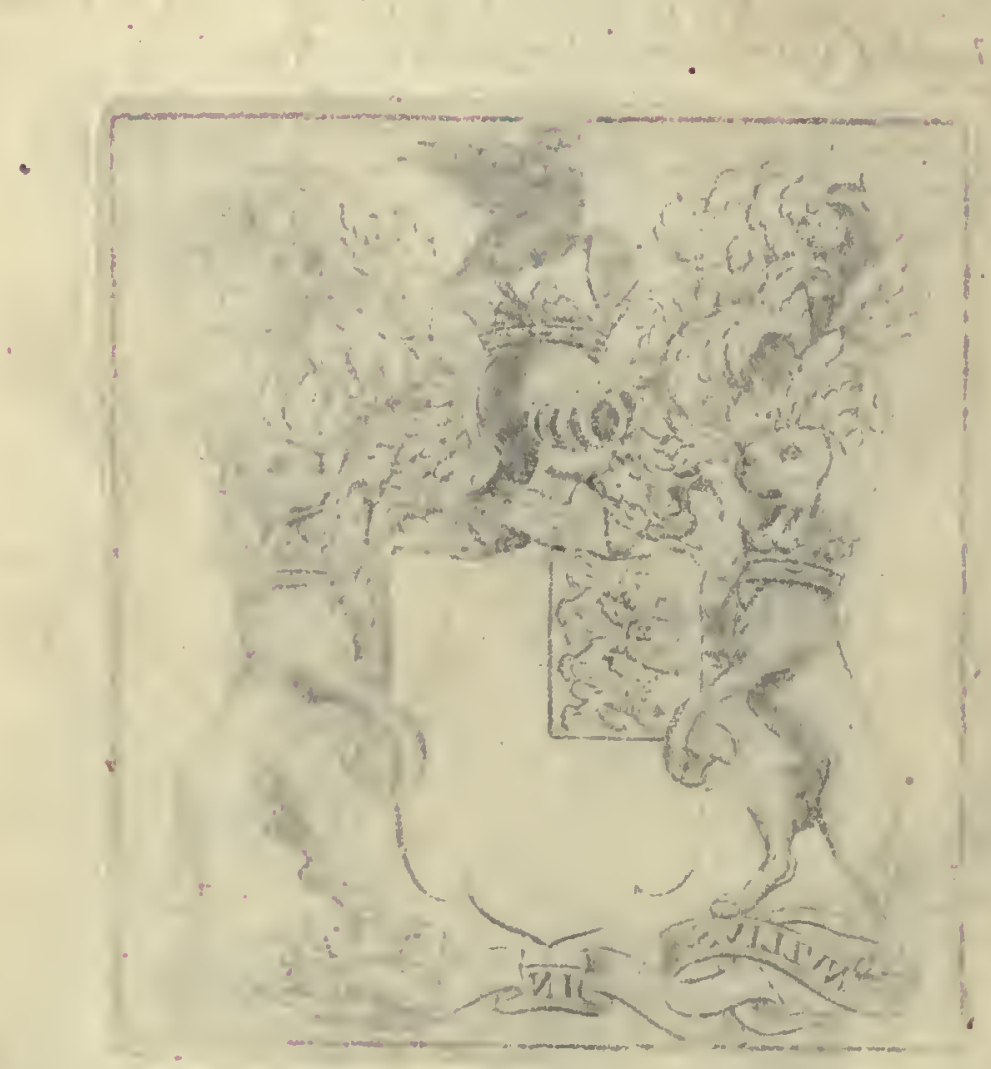

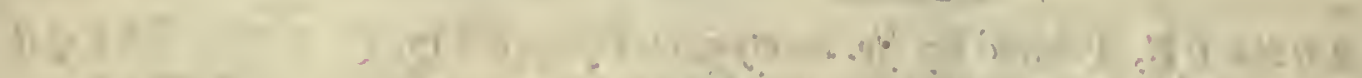
$=-5$ - 
TO THE

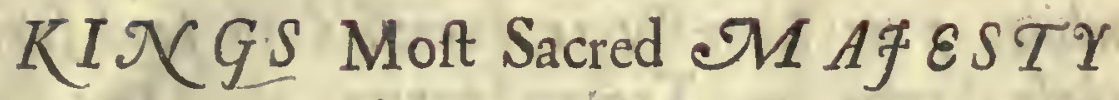

$\eta P_{2}$

\section{Charles the Second.}

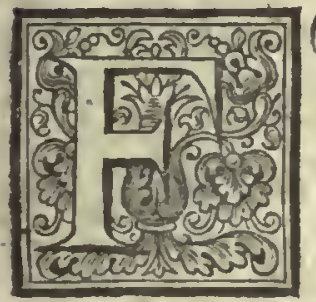

$R$ To whom, Sir, with equal right ought I to Prefent this Publique Fruit of your R O Y A L S O C B T Y, then to its Royal FOVN (DER? and this Difcourfe of Trees, then to your Sacred Majelty, tanquam NEMORUM cato de RR. VINDICI? As of old they pay'd their Devoti- Aurel. ons HER CULI \& S Y L A NO; fince Glop. Phill. You are our ois inaxis,s, Nemorenfis Rex, as bas quill. And fo ving once your Temple; and Court too under that Deus NemeHoly-Oak which you Con/ecrated with your Pre- ibib.4. fence, and We celebrate with juft Acknowledgment to God' for your Prefervation.

Zut-your Majefty bas yet anotber Title to this Work, and to all it pretends to; as baving (like anotber Cyrus) by your own Royal Example, exceeded all yiur. Predecelfors in the Plantations which you bave already made, and now defign, beyond (I dare affirm ii) all the Monarchs of this Nation fince the Conqueft of it. And indeed, what is there more Auguit, more worthy of your Majefty, or more becoming our Imitation? then whilf you are thus folicitous for our. Inftruction, we pur. ue your Majefties great Example with that Veneration which is due to it? and by culti-

$$
\text { A } 3 \text { varing }
$$




\section{The Epiftle Dedicatory.}

vating our decaying Woods, contribute to your Power, as to our greate/ Wealth and Safety; frnce, mbiles your Majenty is furnifb'd to fend forith Arron, I.I. ship built of Inland, we are to fear notbing from without it; and
the Dodone${ }_{a n} 0_{a x}$ whone- whleft We remain obedient to your Commands and great Example, notbing from witbin it: For, as no Jew el in your Majefties reeplendent Crown can render you fo much Luftre and Glory as your regards to Navigation; fo, nor can any tbing im. peach your Navigation, and the Reputation of That, whiles you continue tbus.careful of your Woods and Forefts. I Ball add no more Sir to This, then to Jupplicate your Majefties gracious Acceptance of $m y$ Obedience to the Commands of your S OCI ETY, who impos'd this Province on,

Says-Court May 29. 1663 .

\section{SIR,}

Your Majefties ever Loyal, moft Obedient, and Faithful Subject, and Servant 


\section{TO THE}

\section{R E A D E R.}

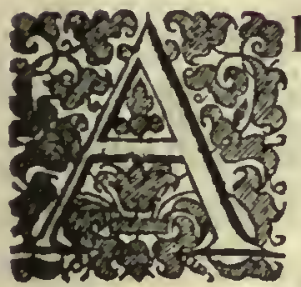

Fter what the Frontipece and Porch of this Wooden Edifice prefents you, I thall need no farther to repeat the Orcafion of this following Difcourse : I am only to acquaint you, That as it was deliver'd to the R OYAL SOCIETY by an unworthy Member thereof, in obedience to their Commands, by the fame it is now publifh'd without any further Profpect. And the Reader is to know, That if thele dry ficks afford him any Sap, it is one of the leaft and meaneft of thofe Pieces which are every day produc'd by that Illuftrious 'Affembly, and which enrich their Collections, as fo many Monuments of their accurate Experiments, and Publique Endeavours, in order to the production of real and ufeful Theories, the Propagation of Natural Science, and the honour of their Inftitution. If to this there be any thing fubjoyn'd bere, which may a while befpeak the patience of the Reader, it is only for the Encouragement of an Induffry, and worthy Labour, too much in our days neglected, as haply efteem'd a confideration of too fordid and vulgar a nature' for Noble Perfons and Gemtlemen to bufic themfelves withal, and who oftner find ways to fell down and deftroy their Trees and Plantations, then cither to repair or improve them.

But what fhall I then fay of our late prodigious Spoilers, whofe furious devaftation of fo many goodly Woods and Forefts liave left an Infamy on their Names and Memories not quickly to be forgotten! I mean our unhappy $v$ Surpers, and injurious Sequeftrators; Not here to mention the deplorable neceffities of a Gallant and Loyal Gentry, who for their Compofitions were (many of them) compell'd to add yet to this Wafte, by an inhumane and unparallel'd Tyranny over them, to preferve the poor remainder of their Fortunes; and to find them Bread. 


\section{To the Reader.}

Nor was it here they defifted, when, after the fate of that beautiful Grove under Green-woich Caftle, the Royal Walk of Elms in ' $S^{\text {' }}$ ames's Park,

Mr. Waller's Poem of St. Famcs's Park.

Tafjo, Cant. 18.

\section{- That living Gallery of aged Trees,}

(as our excellent Poet calls it) was once propofing to the late Council of State to be cut down and fold, that with the reft of His Majefties Houfes already demolith'd; and mark'd out for deftruction, His Trees might likewife undergo the fame deftine, and no footfeps of Monarchy remain unviolated. This is a Truth; which coming by chance to hear of, I fo conjur'd a powerful Member of it (and one who was to ftrike a principal ftroake in this barbarous Execution) that if my Autbority did not refcue thoof Trees from the $A x$, fure I am, my Arguments did abate the Edge of it; nor do I ever pafs under that Majeftical fbade but methinks I bear it falute me as once the Hamadryad did the good Rinaldo,

Ben caro ginngi in quefte cbioftre amene.

$$
\begin{aligned}
& \text { Ouefta Selva, che dianzi era fi negra, } \\
& \text { Vedicbe tutto al tuo venir s' allegre, } \\
& \text { E'n più leggiadre forme è reveftita. }
\end{aligned}
$$

It is from hence you may calculate what were the Defigns of thofe excellent Reformers, and the carc thefe great States-men took for the prefervation of their Countrey, when being Parties in the Booty themfelves; they gave way to fo difhonourable and impolitic a wafte of that Material, which being left intire, or husbanded with difcretion, had prov'd the beft fuppore and defence of it. But this (fay they) was the effect of War, and in the heighth of our Contentions: No, it was a late and cold deliberation, and long after all had been fubdu'd to them; nor could the moft implacable of Enemies have exprefs'd a more barbarous Refolution.

We read of the great Xerxes, that paffing Conqueroin through Achaia, he would not fufter his Army to violate fo much as a Tree of his Advorfaries; it being obferv'd 


\section{To the Reader.}

by the Ancients, that the Gods did never permit him to efcape unpunifh'd who was injurious to Groves, tanquam facros ex vetuftate: What became of Agamemnons Hoft after his fpoil of the Woods at Aulis? Hiftories tell us Cleomenes died mad; the Tamaffean Genius became pro-Temefseus verbial ; and the Mighty. Crefar himfelf carried ('tis. Genius ade' thought) the malediction of the incenfed. Gauls to his Funeral Pile, for the havock he committed at Mafjilia, when he fell'd down thofe goodly Oaks before the face of the fuppliant Priefts, and the curfing People:

$$
\text { Ede Deos? }
$$

But left this be charg'd with'Superftition, becaufe the Inftances are beatben; It was a more noble and remarkable, as well as recent Example, when at the Siege of Breda, the late famous General Spinola commanded his Army not to violate a Tree of a $W$ ood belonging to the Prince of Orange there, though a reputed Traytor, and in open defiance with his Mafter. To be hort, we read, That when Mitbridates but deliberated about the cutting down of fome ftately Trees which grew neer Patara, a City of Lycia, though neceffitated to it for the building of $W$ arlike Engines with them, being terrified in a $V i f i o n$, he defifted from his purpofe. It were to be wihed The fe, or the like Exampler, might have wrought fome Effects upon the facrilegious Purchafers, and dilloyal Invaders, in this Iron-age amongft us, who have lately made fo prodigious a $\int$ piol of thole goodly Forefts, Woods, and Trees (to fatisfie an impious and unworthy Avarice) which being once the Treafure and Ornament of this Nation, were doubtlefs referv'd by our more prudent Ariceftors for the repairs of our floating Caftles, the $\int$ afeguard and boaft of this renouned I Lland, when Neceffity, or fome imminent Peril hould threaten it, or call for their Affiltance; and not to be devour'd by thefe Improvident $W$ retches, who, to their eternal Reproach, did (with the Royal Patrimony) fwallow likewife Gods omn Inberitance; but whofe Sons and Nepheros we have liv'd to fee as haftily difgorge 


\section{To the Reader.}

Qnatibi fa- then again; and with it all the reft of their Purchafes, carum Panas which otherwife they might fecurely have enjoy'd: But infare tno- this in terrorem only, and for caution to Pofterity $;$ whiles Vaticinor:- I leave the Guilty to their proper Scorpions, and to their Vide Met.1.8. Erificbthonian fate, or that of the inexorable Parabius, Apollon.1.2. Argoraut.

\section{Profternit Quercum funeftam quam fibi Nympba Pignoribüsque fuis fecit-.......-}

the vengeance of the Dryads, and to their Tutelar better Genizs, if any yet remain, who love the folid Honour and Ornament of their Country: For what could I fay lefs, * At Wot- 'racyuss, and * Wood-born as I am, in behalf of thofe facred ton in Sur- Sbades, which both grace our Droellings, and protect our rey.

Nation?

But to turn this juft Indignation into Prayers, and addrefs my felf to our better-natur'd Country-men: May fuch Woods as do yet remain intire be carefully Preferv'd, and fuch as are deftroy'd, fedulouly Repair'd. It is what every Perfon who is $O$ woner of Land may contribute to, and with infinite delight, who are touch'd with that laudable Ambition of imitating their moft illuftrious Anceftors, whofe Names we find mingl'd amongft Kings and Pbilofophers, Patriots and Vi. Petrarcb. good Commonwealths-Men: For fuch were of old Solode Remed. mon, Cyrus, and Numa; Licinius fir-named Stolo, Cato, and forrune, li.r. Cincinnatus; the Pifoes, Fabii, Cicero, Plinies, and a thoudial. 57. fand more whom I could ennumerate, that difdain'd not to exercife themfelves in thefe Rufficities, as efteeming it the greateft acceffion of Honour to dignifie their lafting Names with fuch Rural marks as have confecrated their Memories, and tranfmitted them to us through fo many Ages and Viciffitudes of the World.

Let none therefore repute this Induftry beneath him, or as the leaft indignity to the reft of his Qualities, which fo great PerSons have honour'd and cultivated with that afMulre etiam fection and ingenuity.

iffarum $A$ ro The famous Anfwer. which Cyrus gave to Ly fander will

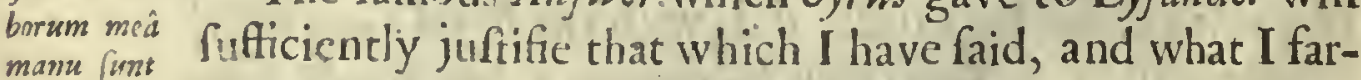
mans: Cyrus ther recommend to fuch Gentlemen as refolve to be Planad Lysand. ters, ouz. That they do not cafily commit themfelves to
Cicir.cx Xenoph.

the 


\section{To the Reader.}

fole Ditlates of their ignorant Hinds and Servants, who Vides Cura are (generally fpeaking) more fit to Learn then to In- tium, $1.7 . \mho_{c}$ : fruê. Male agitur cum Domino quem Villicus. docet, was was an Oblervation of old Cato's; and 'twas Ifchomiachus who told Socrates (difcourfing one day upon a like fúbjeç) That it was far eafier to Make then to Find a good Husband-man: I have often prov'd it fo in Gard'ners; and I believe it will hold in moft of our Country Employments: We are to exact Labour, not Conduct and Reafon, from the greateft part of them; and the bufinefs of Planting is an Art or Science (for fo Varro has folemnly $D_{e} R_{0} \dot{R}_{\text {; }}$ defin'd it) and That excecdingly wide of Truth, which (it feems) many in his time accounted of it; facillimanz effe; nec ulliws acuminis Rufticationem, an eafie and infipid Study. It was the fimple Culture only, with fo much difficulty retriv'd from the late confufion of an inteftine and bloody $W$ ar like Ours, and now put in Reputation again, which made the noble Poet write

\section{$V$ erbis ea vincere magnum}

Georg. 1:

Quam fit, or anguftis bunc addere rebus bonorem.

Séeing, as the Orator does himfelf exprefs it, Nibil eft Inagriserant bomino libero dignius; There is nothing more becoming rus. Cic. de and worthy of a Gentleman.

Senect.

And thus you have in part what I had to produce in extenuation of this my Adventure, that Animated with a Command, and Aflifted by divers Wortby Perfons (whofe Names I am prone to celebrate with all juft Refpects) I have prefumed to caft in my Symbol; and which, with the reft that are to follow, may (I hope) be in fome degree ferviceable to bim (who e're the happy Perfon be) which fhall oblige the World with that compleat Syfteme of Agriculture, which as yet feems a defiderate, and wanting to its perfection. It is (I affure you) what is one of the Principal Defigns of the ROY AL SOCIET, not in this Particular only, but through all the Liberal and more ufeful Arts; and for which (in the eftimation of all equal Fudges) it will merir the greateft of Encouragements; that fo at laft wiat the Learned Columella has 


\section{To the Reader:}

wittily reproach'd, and complain'd of, as a defeet in that Age of bis, concerning Agriculture in general, and is applicable bere, may attain its defired Remedy and Confummation in This of Ours.

Prefat. ad P.

Sylvium;

Sola enim Res Ruftica, qua fine dubitatione proxima, d which I ear- quafi confanguinea Sapientic eft, tam difcentibus egeat, nefly re- to quam magiftris: Adbuc in Scholis R betorum, co Geometrathe ferious rum, Muficorimque; Vel quod inacis mirandum eft, contemperufal of our Gentry. Et mibi ad fapicntis vividetar acce-colationis neque Doctores qui fe profiterentur, néque Difcidere. Cicide pulos cognovi. But this I leave for our Gallants to Interptiffimorum vitiorum officincts, gulofiùs condiendi cibos, ob luxiriofiùs fercula fruendi, capitumque or capillormm concinnatores non folum effe audivi, fed or ipfe vidi; Agricolationis neque Doctores qui fe profiterentur, néque Difcipret, and hould now apply my felf to the Directive Part, which I am all this while befpeaking, if after what I have faid in the feveral Paragraphs of the enfuing Difcourfe upon the Argument of Wood, it might not feem fuperfluous to have premifed any thing here for the Encouragement of fo becoming an Induftry: Let me be permitred to fay, There is fufficient for Inftruction, and more then is extant in any Collection whatfoever ( $a b f i t$ verbo insidia) upon this Jubject; abftracting things Practicable, of folid $u e_{e}$, and material, from the Ostentation and impertinences of Writers; who receiving all that came to hand on truft, to fwell their monftrous Volumes, have hitherco impos'd upon the credulous World, without confcience or bonefty. I will not exafperate the Adorers of our ancient and late Naturalifts, by repeating of what our I'erulam has juftly pronounc'd concerning their $R$ bap odies (becaufe I likewife honor their painful Endeavours. and am oblig'd to them for much of that I know)nor will I( $\mathrm{w}^{\text {th }}$ fome) reproach Pliny, Porta,Cardan,Mizaldus, Curfius, and many others of great Names (whofe $W$ ritings I have diligently confulted) for the $K$ nowledg they have imparted to me on this Oication; but I muft deplore the time which is (for the moft part) fo miferably loft in purfuit of their Speculations, where they treat upon this Argunent: But the World is now advis'd, and (bleffed be God) infinitely redem'd from that bafe and fervile fubmiflion of our nobleft Faculices to their blind Traditions. This, you 


\section{To the Reader.}

will be apt to fay, is a haughty Period; but whiles I affirm it of the Paft, 'it juftifies and does honor to the Prefent Induftry of our Age, and of which there cannot be a greater and more emulous Inftance, then the $P$ affion of His Majefty to encourage His Subjects in all that is laudable and truly emolumental of this nature.

It is not therefore that I here prefume to inftruct Him in the management of that great and auguft Enterprife of refolving to Plant and repair His ample Forefts, and other Magazines of Timber, for the benefit of His Royal Nazy, and the glory of His Kingdoms; but to prefent to His Sacred Perfon, and to the World, what Advifes I have received. from others, obferved my $\int e l f$, and moft Indufrioully Collected from a fudious propenfity to ferve as one of the leaft Intelligences in the ampler Orb of our Illufrious Society, and in a Work fo Important and Neceffary.

$$
\text { F. } E_{\text {: }}
$$




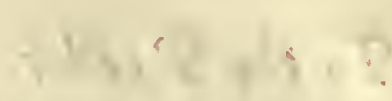

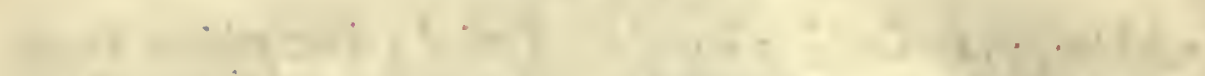

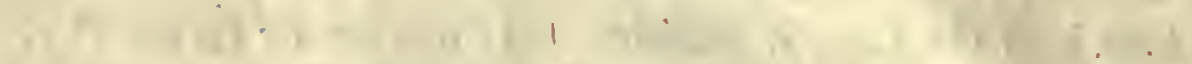

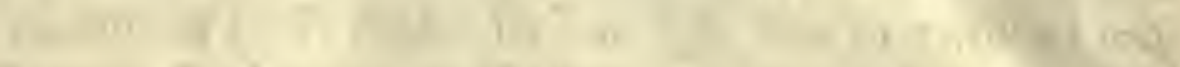
Wo

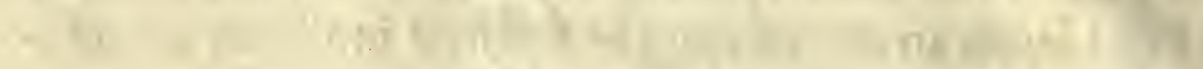

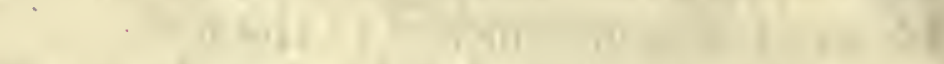
a

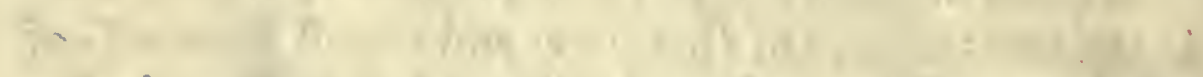

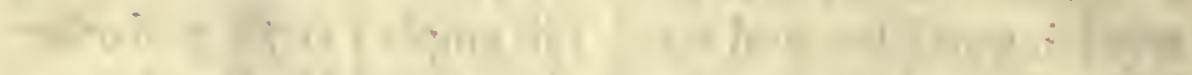

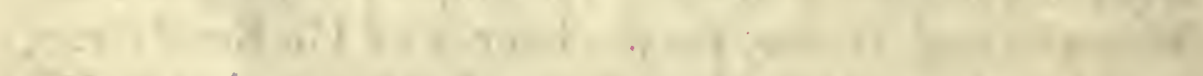

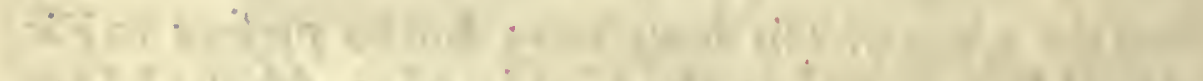

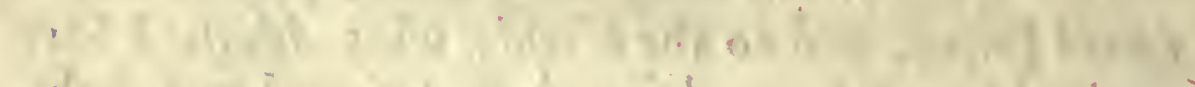

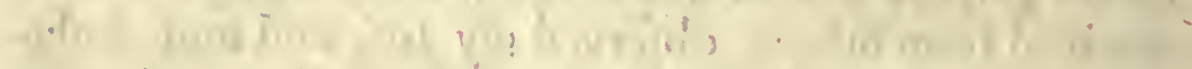

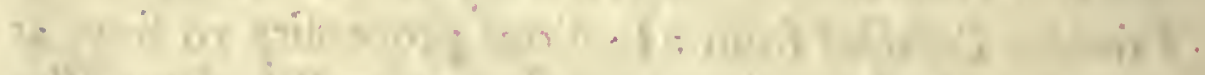

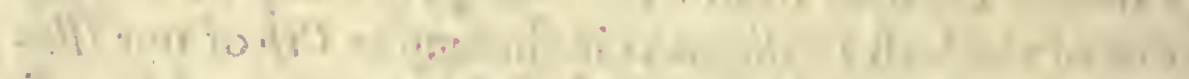

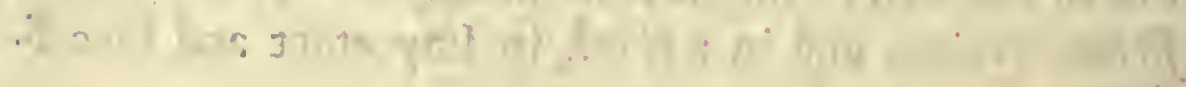

\section{.}

:A $7.1 Y$ 
Amico charisimo fobanni Evelyno Armigero, è Societate Regali Londini. J. Beale, S.P.D. In Sylvam.

TAre age quid canfe eft quod tu Sylveftria pangis;

Inter Sylvanos, capripedésque Deos?

Inter Hamadryadas latus, Dryadáfque pudicas,

Cum tua Cyrrhxis fit Chelys apta modis!

Scilicet boc cecinit numero ofs Horatius olim, Scriptornm Sylvam quòd Chorus Omnis amat. Eft locus ille Sacer Mufis, \&o Apolline dignus, Prima dedit Sunimo Templa Sacranda Jovi. Hinc quoque nunc Pontem Pontus non re/puit ingens,

Stringitur Oceanus, corripitúrque Salum.

Hinc noous Hefperiis emerfit mandus in oris, Effuditque auri flumina larga probi.

Hinc exundarit diftento Copia cornu,

Qualem of Amalthxx non babuere finus.

Sylva tibi cure eft, grata \& Pomona refundit

Auriferum, rofeum, purpurémque nemus.

Illa famémque fitimque abigens expirat odores,

Quales nec Medus, nec tibi mittit Arabs. Ambrofiam prabent modò coßta Cydonia, Tantum

Comprime, NeEtareo poma liquore flunnt.

Progredere, O Sœcli Cultor memorande futuri,

Felix Horticolam fic imitere Detum.

Gen.1. c.ĩ. 


\section{$\triangle$ TABLE Of the CHAPTERS.}

CHAP.

S Y L V A.

Introduction.

Oof the seed.

2 of the Seminary.

3 Of the oak.

4 of the Elm.

5 of the Beech.

6 of the $A$ h. .

7 of the cheß-nut.

8 of the Wall-nit.

-9 of the service.

-10 of the Maple.

II of the sycamore.

12 of the Horn-beam.

- 13 of the Limze-tree.

14 of the 2uick-beam. 31

15 of the Birch.

16 of the Hafel.

17 of the Poplar.

18 of the Alder.

Ig of the Withy, sallow, oxier, and Willow.

20 of Fences, 2uick-fets, \&c. 45

21 of the Fir, Pine, Pinaster, Pitch-tree, \&c. ?' 5 I

22 of the Larch, Platanus; Lotus, \&c.

23 of the Cypreß-tree, and Cedar.

58

24 Of the Cork, Alaternws, Phillyrea, Granad, Mjrtil, Jafmine, \&c.

62

25 of the Acacin, Arbutus, Bays, Box, Eugh, Holly, Funiper, and Laurel-trees.

26 of the Infirmities of Trees. 68

27 of copfes.

28 of Pruning.

29 of the Age, stature, and Felling of Trces.

30 of Timber, the seafoning and Ujes; and of Fuel.

3 I Aphorifms, or certain general Przcepts, of $u$ e to the foregoing Chapters.

105

32 of the Laws and Statuites for the Prefervation and Improvement of Woods, \& c.IO7
CHAP. PagThe Paranefis and Conclufion. II2 POMON.A.

CHAP. The Preface.

Pag. 1 of the seminary.

2 of stocks,

3 of Graffs and Infitions. 8 4 of Variety and Improvements. 4 Io 5 of the Place and order. I5 6 of Tranplanting and Diftance. 17 7 of Fencing.

8 of Pruning, and the ufe of Fruit-Trees.

\section{I D E R.}

Aphorifms concerning Cider by $M$. Beale.

Sir Paul Niele's Difcourfe of $\mathrm{C} i$ der.

obfervations concerning the $M_{a}$ king and Preferving of Cider, by John Newburgh, E $\int$; $\dot{4}$ I Concerning Cider, by Dr Smith. of Cider, by Capt. Taylor. $\quad 47$

\section{KALENDARIUM HORTENSE.}

Introduction.

January. 58,59

February. 60,61 March. 62,63 April. May.

Tunze. 64,65 66,67 July. 68,69 70,71 August.

september. 72,73 74,75 october. $\quad 76,77$ Noveniber. $\quad 78,79$ December. - 80,81 The Catalogue of Plants, Buc. to be fet into the Conferve, or ot hermife defended in Winter. 


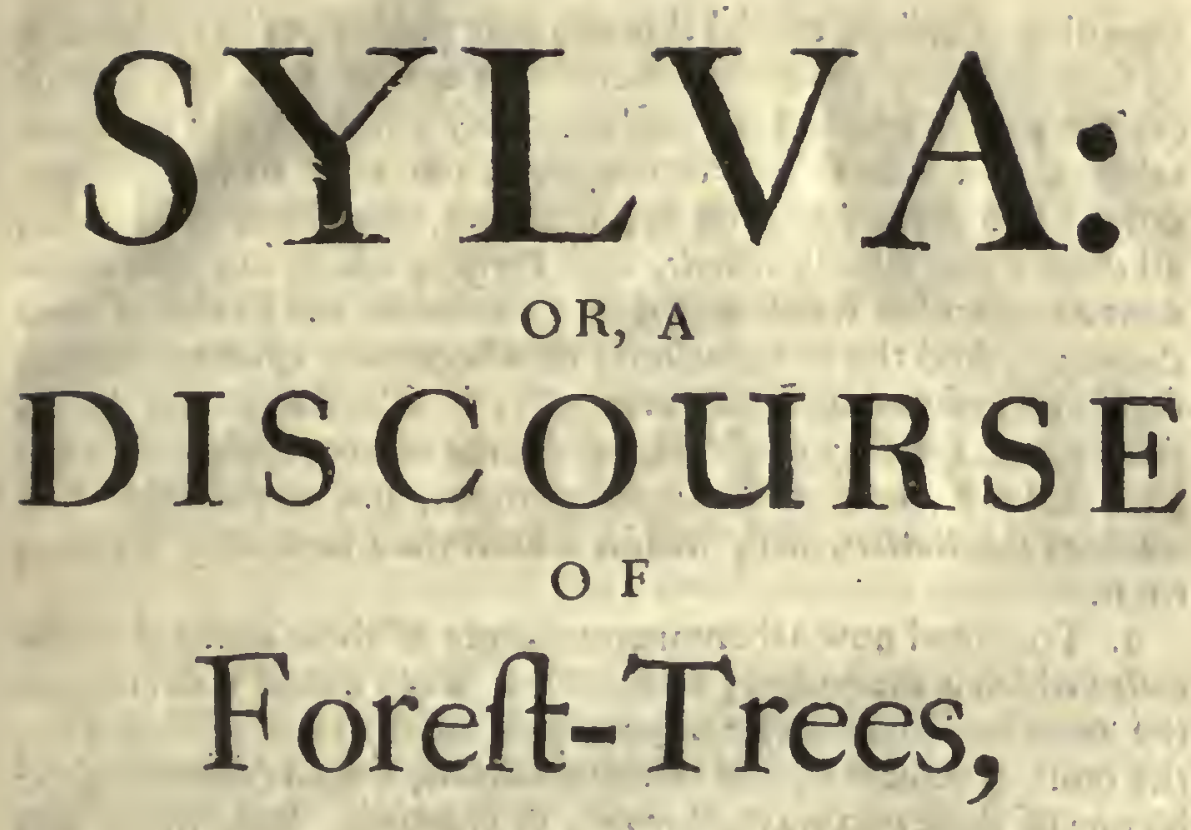

AND

The Propagation of Timber in His MAFESTIES Dominions; \&ic.

Tuque ades, inceptúmque una decurre laborem, $O$ decus; ô fame meritò pars maxima noftre C AROLI DE, pelagóq; volans da veli petenti : Dafacilem curfum, atque audacibus annine captis: Ignavóf que vice mecum miferatus agreftes Ingredere, ou sotis jam nunc affnefce vocari.

The Introduction.

I. Ince there is nothing which feems more fatally Introduction,

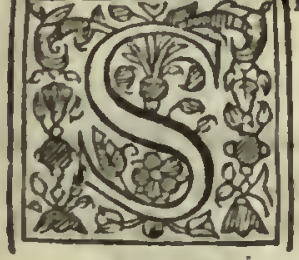
to threaten a Weakning, if not a Diflolution of the frength of this famous and flourifhing Nation, then the fenfible and notorious decay of herWooden-malls, when either through time, negligence, or other accident, the prefent Navy thall be worn out and impair'd; it has been a very worthy and feafonable Advertifement in the Honourable the principal officers and Commi]/soners, what they have lately fuggefted to this Illuftrious Society; for the timely prevention and redrefs of this intollerable defect. For it has not been the late increafe of shipping alone, the multiplication of Glaß-morks, IronFurnaces, and the like, from whence this im-politick diminution of our Timber has procceded; but from the difproportionate B fpreading G has. 


\section{A Difcourfe of Foreft-Trees.}

fpreading of Tillage, cauled through that prodigious havock made by fuch as lately profeffing themfelves againft Root and Branch (either to be re-imbaurs'd of their boly purchafes, or for fome other fordid refpect) were tempted, not only to fell and cut down, but utterly to grub up, demolifh, and raze, as it were, all thofe many goodly Woods, and Forefts, which our more prudent Anceftors left tanding, for the Ornament, and fervice of their comntry. And this devaltation is now become fo Epidemical, that unlefs fome favourable expedient offer it felf, and a way be $\mathrm{e}$ rioully, and fpeedily refolvd upon, for the future repair of this important defezt, one of the moft glorious, and confiderable Balmarks of this Nation, will, within a thort time be totally wanting to it.

2. To attend now a fpontaneots fupply of thefe decay'd Materials (which is the vulgar; and natural way) would coft (befides the Inclofure) fome entire Ages repole of the Plow: Therefore, the moft expeditious, and obvious Method, would (doubtlefs) be by one of thefe two ways, sowing, or Planting. But, firft, it will be requifite to agree upon the species; as what Irees are likely to be of greateft $\mathcal{V} e$, and the fitteft to be cultivated; and then, to confider of the Manner how it may beft be effected. 'Truly, the rafte, and deftruction of our Woods, has been fo univerfal, that I conceive nothing lefs then an univerfal Plantation of all the forts of Trees will fupply, and well encounter the defect; and therefore, I thall bere adventure to peak fometning in general of them all; though I chiefly infift upon the propagation of fuch only as feem to be the moft wanting, and ferviceable.

3. I diftribute them, therefore, into thefe two Clafes, the Dry, and the Aquatic; both of them applicable to the fame civil ufes of Building, Vtenfils, Ormament and Fuel; for to dip into their Medicinal virtues is none of my Province.

Among the dry, I efteem the more principal, and folid, to be the oak, Elme, Beech, Ajh, Chess-nut, Wall-nut, ouc. The lefs princi$\mathrm{pal}$, the Service, Maple, Lime-tree, Horn-beam, 2uick-beam, Bircb, $\mathrm{Hafel}$, \&cc. together with all their fub-alternate, and feveral kinds.

\section{Sed neque qràmi mult repecies, nec nomina que. [int Eft numerus, Geor.}

Of the Aquatical; I reckon the Boplars, AfP, Alder, Willow, sallow, ofier, Gic. Then I fhalladd a.word or two, for the encouragement of the planting of Fruit-trees, together with fome lefs vulgar, but no lefs ufeful Trees, which, as yet are not endenizon'd amongft us, or (at leaft) not much taken notice of : And in purfisance hereof, I thall obferve thisorder : Firft, to fluew how they. are to be Raifed; and then to be Cultivated: By.Raifng, I underftand the. Seed and the Soil; by Culture the Planting, Fencing; Watering, Drelfing, Pruning and Cutting; of all which briefly. 
And firft for their Raifing, fome thereare mullis bomimum cogentibus, ip $\sqrt{2}$

sponte fur veniunt__ Specifying according to the various difpofition of the Air, and soil.

Pars autem pofito furgunt de femine. As the $0 a k$, cheß-nut, $A \beta, \delta c$.

Pullulat ab radice alios denfylima sylva. As the Elme, Alder, \&c. and there are others

Nil radicis egent- Growing without any fuch Roots; as Willows, and all the Vimineous kinds, which are raifed of Sets only.

Hos natura modos primin in dedit - For thus we fee there are more ways to the Wood then one ; and Nature has furnilh'd us with variety of expedients.

4. But it has been fifly controverted by fome, whether were better to raife Trees for Timber, and the like ufes, from their seeds and firft Rudiments; or to Tranplant fuch as we find have either rais'd themfelves from their Seeds, or fiping from the Mother-roots. Now, that to produce them immediately of the seed. is the better way, thefe Reafons may feem to evince.

Firft, becaufe they take fooneft. secondly, bccaufe they make the ftraighteft, and moft uniform thoot. Thirdly, becaufe they' will neither require ftaking, nor watering (which are two very confiderable Articles) and laftly, for that all tranplanting (though it much improve Fruit-trees.) unlefs they are taken up the firft Year, or two, is a confiderable impediment to the growth of $\mathrm{Fo}_{\mathrm{O}}$ reft-trees. And, though it be true that divers of thofe which are found in Woods, efpecially Oaklings, young Beeches, $A \beta$, and fome others, fpring from the felf-fown maft and keys; yet, being for the moft part dropp'd, and diffeminated amongft the half-rotter fticks, mufty leaves, and perplexities of the motber-roots, they grow fcraggy ; and being over-dripp'd become fqualid and moffie, which checks their growth, and caufes them to dwindle:

\section{Crefcentíque adinunt fatus, urunitque ferentem.}

Nor can their roots expand; and fpread theinfelves as they would, do if they were fown, or had been planted in a more open, free, and ingenuous soil. And that this is fo, I do affirm upon Experience, that an Acorn fown by hand in a Nurfery, or ground where it may be free from thefe encumbrances, fhall in two or three Years out-frip a Plant of twice that age, which has either been felf-fown in the Woods, or removed; unlefs it fortune, by fome favourable accident, to have been fcatter'd into a more natural, penetrable, and better qualified place : But this difproportion is yet infinitely more remarkable in the Pine, and the $W$ all-nut-tree, where the Nut fet into the ground fhall certainly overtake a T'ree of ten years growth which was planted at the fame inftant; and this is a secret fo generally mif-reprefented by moft of thofe who have treated of thefe fort of Irees, that I could not fuffer it to C 2 pals 


\section{A Difcourfe of Foreft-Trees.}

pafs over without a particular remark; fo as the noble Poet (with pardon for receding from fo venerable Authority) was certainly miftaken, when he delivers this obfervation as univerfal, to the prejudice of sowing, and raifing Woods from their Rudiments :

Nam que feminibus jact is fe fuftulit arbos Tarda venit; feris factura nepotibus umbram.

Geor.l.2。

\section{CH A P. I. \\ of the Seed.}

Seed. I. RUt to commence with the Method propos'd: Chufe your B seed of that which is perfectly mature, ponderous and found; commonly that which is eafily thaken from the boughs, or gathered about November, immediately upon its fpontaneous fall, is beft, and does (for the moft part) direct to the proper feafon of interring, $\mathcal{C}^{c}$. according to the Inftitution of Nature her felf:

Nam Jecimen fationis, dinfitionis origo

Ip $\int$ fuit rerum primum natura creatrix :

Arboribus quonians bacce, glandé fque caduce

Tempeftiva dabant pullorum examina fubter, óc.

Lucret. 1.5 .

Yet this is to be confider'd, that if the place you fow in be too cold for an Autumnal femination, your Acorns, Maft, and other Seeds may be prepared for the Vernal by being barrell'd, or potted up in moift sand or Earth ftratum S. S. during the Winter; at the expiration whereof you will find them $\beta$ prouted; and being committed to the Earth, as apt to take as if they had been fown with the moft early : by this means, too, they have efcaped the Vermine (which are prodigious devourers of Winter fowing) and will not be much concern'd with the increafing heat of the seafon, as fuch as being crude, and unfermented are newly fown in the beginning of the spring; efpecially in hot and loofe Grounds; being already in fo fair a progrefs by this artificial preparation; and which (if the provifion to be made be very great) may be thus manag'd. Chufe a fit piece of Ground, and with boards (if it have not that pofition of it felf) defign it three foot high; lay the firft foot in fine Earth, another of Seeds, Acorns, Maft, Keys, Nuts', Haws, Holly-berries, \&uc. promifcuoully, or feparate, with (now, and then) a little Monld Sprinkled amongft them: The third foot wholly Earth: Of thefe preparatory Magazines make as many, and as much larger-ones as will ferve your turn, continuing it from time to time as your ftore is brought in. The fame may you alfo do by burying your Seeds in Sand, Barrel- 
ling them (as I faid) in Tubs, or laid in heaps in fome deep Cellar where the rigour of the Winter may leaft prejudice them; and I have fill'd old Hampers, Bee-bives, and Boxes withithem, and found the like advantage, which is to have them ready for your seminary, as before hath been thew'd, and exceedingly prevent the feafon.

2. But to purfue this to fome farther Advantage; as to what concerns the election of your Seed, It is to be confider'd, that there is vaft difference in Trees even of the fame growth and bed, which I judge to proceed from the variety and quality of the seed: This, for inftance, is evidently feen in the heart, procerity and ftature of Timber; and therefore chufe not your Seeds always from the moft Fruitful-trees, which are commonly the moft Aged, and decayed; but from fuch as are found moft folid and fair: Nor, for this reafon, covet the largeft Acorns, Euc. (but as Hufband-men do their Wheat) the mont weighty, clean and bright: This Obfervation we deduce from Fruit-trees, which we feldom find to bear fo kindly, and plentifully; from a found ftock, Jmooth Rind, and firm Wood, as from a rough, lax, and untoward Tree, which is rather prone to fpend it felf in Fruit, the ultimate effort, and final endeavour of its "moft delicate sap, then in folid and clofe $\int u b f$ tance to encreafe the Timber. And this fhall fuffice, though fome haply might here recommend to us a more accurate Microfcopical examen, to interpret their molt fecret Schematifnies; which were an over inicity for thefe great Plantations.

3. As concerning the medicating, and infuccation of seeds, or enforcing the Earth by rich and generous Compofts, ouc. for Trees of thefe kinds, I am no great favourer of it; not only, becaufe the charge would much difcourage the Work; but for that we find it unneceffary, and for moft of our foreft-trees, noxious; fince even where the Ground is too fertile, they thrive not fo well; and if a Mould be not proper for one fort it may be fit for another: Yet I would not (by this) hinder any from the trial, what advance luch Experiments will produce: In the mean time, for the fimple Imbibition of fome Seeds and Kerizels, when they prove extraordinary dry, and as the Seafon may fall out, it might not be amifs to macerate them in Milk, or $\bar{W}$ ater only, a little impregriated with Cons-dung, occ. during the fpace of twenty four hours, to give them a pirit to fprout, and chet the fooner; efpecially, if you have been retarded in your fowing without our former preparation.

4. Being thus provided with seeds of all kinds, I would advife to raife Woods by fowing them apart, in feveral places deftin'd for their growth, where the Mould being prepard (as I hall thew hereafter) and fo qualified-(if election may be made) as beft to fuit with the nature of the species, they may be fown promifcuonfly, which is the moft natural and Rural; or in ftraight and even lines, for Hedge-rons, Avenues, and Walks, which is the more Ornamental : But becaufe fome may chufe rather to draw them out of Nurferies; that the Culture is not much different, nor the hinderance confiderable (provided they be early, and carefully Re- 
moved) I will finith what i have to fay concerning thefe Tress in the seminary, and fhew how they are there to be Raifed; Tramplanted, and Govern'd till they can fhift for themlelves.

\section{CHAP. II. \\ of the Seminary:}

1. ViVineam; vel Arbuftum conftituere volet, Seminariapriùs 1. facere debebit, was the precept of Columtella, l.3.c.5. fpeaking of Vineyards and Fruit-trees: and, doubtlefs, we cannot purfue a better Courfe for the propagation of Timber-trees: For though it feem but a trivial defign that one fhould make a Nurfery of Forefters; yet is it not to be imagin d, without the experience of it, what prodigious Numbers a very fmall $\beta$ pot of Ground well Cultivated, and deftin'd for this purpore would, be able to furnilh towards the fending forth of yearly Colonies into all the' naked quarters of a Lordfipip, or Demeafnes; being with a pleafant Induftry liberally diftributed amongt the Tenants, and difpos'd of about the Hedge-roms, and other Wafte, and uncultivated places, for Timber, shelter, Fuel, and ornament, to an incredible Advantage. This being a cheap, and laudable Work, of fo much pleafure in the execution, and fo certain profit in the event; to be but once well done (for, as I affirm'd, a very fmall Nurfery will in a few Years people a vaft extent of Ground) hath made me fometimes in admiration at the univerfal negligence.

" 2. Having therefore made choice of fome fit place of Ground, well Fenced, refpecting the Soutb-eaft, rather then the full South, and well protected from the North and $W \mathrm{eft}$; let it be Broken up the Winter before you fow, to mellow it, efpecially if it be a Clay, and then the furrow would be made deeper; or fo, at leaft, as you would prepare it for Wheat: Or you may Trench it with the spade, by which means it will the eafier be cleanfed of whatfoever may obfruct the putting forth, and infinuating of the tender Roots: Then having given it a fecond ftirring, immediately before you fow, caft, and difpofe it into Rills, or fmall narrow Trenches of four, or five inches deep, and in even lines, at two foot interval, for the more commodious Runcation, Hawing, and dreffing the Trees: Into thefe Furrows (for a Confeminea sylva) throw your Oak, Beech, Afh, Nuts, all the Glandiferous Seeds, $M a f$, and Key-bearing kinds, fo as they lye not too thick, and then cover them very well with a Rake, or fine-tooth'd Harrow, as they do for Peafe: Or, to be inore accurate, you may fet them as they do Beans (cipecially, the Nuts and Acorns) and that every species by themfelves, which is the better way: This is to bedone at the latter end of october, for the Autumual fowing; and in the lighter ground, about February for, the Vernal.

3. Your Plants beginning now to peep fhould be earthed up, 


\section{A Difcourfe of Foreft-Trees,}

and comforted a little; efpecially, after breaking of the greater Frofts, and when the fwelling mould is apt to fpue them forth; but when they are about an inch above ground you may, in a moift feafon; draw them up where they are too thick; and fet them immediately in other lines, or Beds prepared for thein; or you may plant them in double fofjes, where they may abide for good and all, and to remain till they are of a competent ftature to be Tranplanted; where they fhould be fet at fich diftainces as their feveral kinds require; but if you draw them only for the thinning of your Seminary, prick them into fome empty Beds at one foot interval, leaving the reft at two or three.

4. When your seedlings have ftood thus till Fune, beftow a half digging upon them, and fatter a little mungy, half rotten Litter, Fearn, Bean-bame, or old Leaves, among them, to preferve the Roots from fcorching, and to entertain the moifture; and then in March following (by which time it will be quite confum'd and very mellow) you thall chop it all into the earth, and mingle it together: Continue this proces for two or three years fucceffively, and then (or before, if the ftature of your young Impes invite) you may plant them forth, carefully taking up their koots, and cutting the stem within an inch of the ground (if the kind; of which hereafter, fuffer the knife) fet them where they are to continue : Some repeat this, the fecond rear, and after March (the Moon decreafing) recut them at half a foot from the furface ; and then meddle with them no more : but this (if the process be not inore fevere thien needs) muft be done with a very tharp Inftritt ment, and with care, leff you violate, and unfettle the Root; which is likewife to be practis'd upon all thofe which you did not Transplant, unlefs you find them very thriving Tres;, and then it thall fuffice, toprune off the Branches, and fpare the Tops; for this does not only greatly eftablifh your Plants, by diverting the sap to the Roots; but likewife frees them from the injury and concuffions of the Wind's, and make's them to produce handfome, ftraight froots, infinitely preferable to fuch as are abandon'd to Nature, and Accident, without this difcipline : By this means the Oak will become excellent Timber, fhooting into ftraight and fingle ftems : The cheßs-nut, Afn, \& c c multiply into Poles, which you may reduce' tojtandards at pleafure.

5. The Author of the Natural Hiftory, Pliny, tells us it was a vulgar Tradition, in his time, that no Tree fhould be Removed under two years old; or above three: Cato' would have none' Tranf planted lefs then five fingers in diantetre; but I have lhew' $\mathrm{d}$ why we are not to attend fo long, for fuch as we raile of seedlings: In the interim, if thefe directions appear too bufie, or operofe, or that the Plantation you intend be very ample; a more compendious' Method will be, the confufed fowing of Acorns, \&uc. in Furrows, two foot afunder, covered at three fingers depth, and fo for three years cleanled, and the firft Winter cover'd with fearn; without any farther culture, unlefs you Transplant them; but, as I fiewed before, in Nurferies they'would be cut' an inctifrom the Ground, 
and then let ftand till March the fecond year, when it thall be fuffcient to disbranch them to one only thoot; whether you fuffer them to ftand, or remove them elfewhere. But to make an Effay what Seed is moft agreeable to the Soil, you may by the thriving of a promifcuous semination make a judgement of it, Tranfplanting thofe which you find leaft agreeing with the place; or elfe, by copfing the ftarvling in the places where they are new fown, caufertiem fometimes to overtake even their untouch d contemzporaries. But I now proceed to particulars.

\section{CHA P. III.}

$$
\text { of the Oak. }
$$

Oxk. I. Have fometimes confider'd it very ferioufly, what thould move Pliny to make a whole Chapter of one only Line, which is lefs then the Argument of moft of the reft in his huge Volumn : but the weightinefs of the Matter does worthily excufe him, who is not wont to fpare his Words, or his Reader. Glandiferi maximè generis onuzes, quibus honos apud Romanos perpetuzs. "Maft-bearing-trees were they principally which the Romans "beld in chiefeft reputation, li.6. cap. 3. And in the following where he treats of chaplets, and the dignity of the Cives's Coronet, it might be compos'd of: the Leaves or Branches of any Oak, provided it were a bearimg. Tree, and had Acorns upon it. It is for. the efteem which thefe toife, and glorious people, had of this Tree above all others, that I will firft begin with the Oak.

2. The Oak is of four thinds; two of which are moft common with us; the 2uercus urbana, which grows more up-right, and being clean, and lighter is fittelt for Timber : And the Robur or 2 uercus sylveftris, which is of an hard, black grain, bearing a finaller Acorn, and affecting to fpread in branclies, and to put forth his Roots more above ground; and therefore in the planting, to be allow'd a greater diftance; viz. from twenty five, to forty foot; whereas the other hooting up more erect will be contented with fifteen: This kind is farther to be diftinguifh'd by his fullnefs of leaves, which tarnifh, and becoming yellow at the fall, do commonly clothe it all the Winter, the Roots growing very deep and ftragling. The Author of Britannia Baconica fpeaks of an Oak, in Lanbadron Park in Cornwall, which bears conftantly leaves fpeckl'd with White; and of another call'd the Painted-oak, which I only mention here, that the variety may be compar'd by fome ingenious perfon thereabouts, as well as the truth of the fatal pre-admonition of oaks bearing trangeleaves. It is in the mean time the propagation of this large fpreading, $c c$.

3. Oak, which is elpecially recommended for the excellency of the Timber, and that his Majefties Forefts were well and plenti-

fully 


\section{A Difcourfe of Foreft-Trees.}

fully ftor'd with them; becaufe they require room, and fpace to amplifie and expand themfelves, and would therefore be planted at more remote diftances, and free from all encumbrances: And this upon confideration how flowly a full-grown Oak, mounts upwards, and how fpeedily they fpread, and dilate themfelves to all quarters, by dreffing and due culture; fo as above forty years advance is to be gain'd by this only Induftry: And, if thus his $M a-$ jefties Forefts, and chafes, were ftor'd; viz. with this Jpreading Tree at handfome Intervals, by which Grazing might be improv'd for the feeding of Deer and Cattel under them, benignly vilited with the gleams of the Sun, and adorn'd with the diftant Landskips appearing through the glades, and frequent Vallies

Cerula diftinguens inter plag a currere poffet

Per tumulos, \& convalles, campofque profufa:

Ut nuuc effe vides vario diftincta lepồre

omnia, que pomis interfita dulcibus ornant

Arbuftifque tenent felicibus obfita circum:

As the Poet incomparably defcribes his olive-groves,

Whofe rows the azure skie is feen immix'd,

With Hillocks, Vales, and Fields, as now you fee

Diftinguifh'd with a fweet variety;

Such places which wild Apple-trees throughout

Adorn, and happy forubs grow all about.

Iucret. lib. 5 .

(For fo we might alfo fprinkle Fruit-trees amongft them (of which hereafter) for cider and many fingular ufes) we thould find fuch goodly Plantations the boaft of our Rangers, and Forefts infinitely preferrable to any thing we have yer beheld, rude, and neglected as they are: I fay, when his Majefty thall proceed (as he hath defign'd) to animate this laudable pride into fafhion, Forefts and Woods (as well as Fields and Inclofures) will prefent us with another face then now they do. And here I cannot but applaud the worthy Induftry of old Sir Harbotle Grimftone, who (I am told) from a very fmall Nurfery of Acorns which he fow'd in the neglected corners of his ground, did draw forth fuch numbers of oaks of competent growth; as being planted about his Fields in even, and uniform rows, about one hundred foot from the Hedges; bufh'd, and well water'd till they had fufficiently fix'd themfelves, did wonderfully improve both the beauty, and the value of his Demeafnes. But I proceed.

4. Both thefe kinds would be taken up very young, and Tranfplanted about Odtober; and though they will grow tolerably in moft grounds; yet do they generally affect the found, black, deep and faft mould, rather warm then over wet and cold, and a little rifing; for this produces the firmeft Timber; and fo our former Naturalift 


\section{- in montem fuccedere fylvas}

Cogebant.

\section{Lucret.}

though my L. Bacon prefer that which grows in the moifter grounds for ship-timber, as the moft torgh, and lefs fubject to rift: but let us hear Pliny. This is a general Rule, faith be; "What Trees foever they be which grow tolerably either on. "Hills, or Vallies, arife to greater fature, and fpread more amply "s in the lower ground: But the Timber is far better, and of a finer "grain, which grows upon the Mountains; excepting only Apple, "c and pear-trees. And in the 39.cap. lib. 16. The Timber of thofe "Trees which grow in moift and frady places is not fo good as " that which comes from a more expos'd fituation, nor is it fo clofe, "fubftantial and durable; upon which he much prefers the Tim"ber growing in Infcany, before that towards the Venetian fide, "and upper part of the Gulpb: And that Timber fo growing was in greateft efteem long before Pliny, we have the Spear of Agamemnon

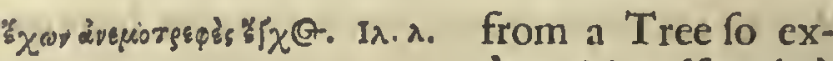
pos'd; and Dydimws gives the reafon. Ta' yaj is dives (fays he)

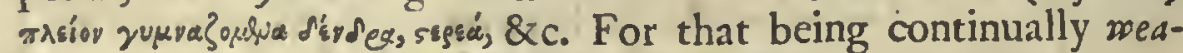
ther-beaten they become hardier and tougher.

5. But to difcourage none, Oaks profper exceedingly even in gravel, and moift Clays, which molt other Trees abhor; yea, even the coldeft clay grounds that will hardly graze: I have read, that there grow Oaks (fome of which have contain'd ten loads apiece) out of the very Walls of silcefter in Hanthire, which feem to Arike root in the very stones. It is indeed obferv'd, that oaks which grow in rough, ftony grounds, and obftinat clays, are long before they come to any confiderable ftature; for fuch places; and all fort of Clay, is held but a ftep-motber to Trees; but in time they afford the moft excellent Timber, having ftood long, and got is good rooting : The fame may we affirm of the lighteft fands, which produces a fmoother'-grain'd Timber, of all other the mort ufeful for the Joyner. What improvement the ftirring of the. ground about the roots of Oaks is to the Trees I have already hinted; and yet in Copses where they ftand marm, and fo thickn'd with the under-wood, as this culture cannot be practis'd, they prove in time to be goodly Trees.

6. That the Tranfplanting of young Oaks gains them ten years Advance fome happy perfons have affirmed : from this belief, I have defir'd to be cxcufed, and produc'd my Reafons for it : Nor lels are they miftaken, who advife us to plant 0 aks of a great bigne $\beta$, which hardly make any confiderable progreß in an Age: Yet if any be defirous to make trial of it, let their stems be of the fmootheft, and tendereft Bark; for that is ever an indication of youth, as well as the paucity of their Circles, which in difbranching, and cutting the head off, at five or $f(x$ foot height (a thing, by the way, which the French ufually fpare when they Tranjplant this Tree) 


\section{A Difcoirfe of Forelt-Trees:}

may (before you ftir their 'Roots) ferve for the more certain Guide; and then plant them immediately', with as much Earth as will adhere to them, in the place deftin'd for theirftation; abating only the tap-roots, which is that down-right, and ftubby part of the Roots (which all Trees rais'd of seeds do univerfally produce) and quickning fome of the reft with a fharp knife (but fparing the Fibrous, which are the main suckers and Mouths of all Trees) fpread them in the fo $\beta$, or pit which hath been prepar'd to receive them. I fay in the fo/s, unlefs you will rather trench the whole Field, which is incomparably the beft; and infinitely to be preferr'd before narrow pits and holes (as the manner is) in cafe you plant any number confiderable, the Earth being hereby made loofe, eafier and penetrable for the Roots; about which you are to caft that Mould which (in opening of the Trench) you took from the Surface, and purpofely laid apart; becaufe it is fweet; mellow, and better impregnated: But in this Work; be circumfpect never to inter your Stem deeper then you found it ftanding; for profound buryings very frequently deftroys a Tree; though an $\mathrm{Er}$ rour feldom obferved : If therefore the Roots be fufficiently cover'd to keep the Body fteady and errect, it is enough; and the not minding of this trifling Circumftance does very much deceive our ordinary Wood-mzen: For moft Roots covet the Air (though that of the Quercus urbana leaft of any :

\section{quìdquantum vertice ad aur as \\ Xthereas, tantum radice ad tartara tendit)}

And the perfection of that does almoft as much concern the: profperity of a Tree, as of Man himfelf; fince Homo is but Arbor. inverfa; which prompts me to this curious, but important $A d$ vertifement; That the Pofition be likewife feduloufly obferved.

7. For, the Southern parts being more dilated, and the pores expos'd (as evidently appears in their Horizontal Sections) by the conftant Excentricity of their Hyperbolical Circles; being now on the fudden, and at fuch a feafon converted to the North, doesferve, and deftroy more Trees (how careful foever men have been in ordering the Roots, and preparing the Ground) then any other Accident whatfoever (neglect of ftaking, and defending from Cattle excepted) the importance whereof caufed the beft of Poets, and moft experienc'd in this Argument, giving advice concerning this Article, to add

\section{2uinetiam Celi regionem in cortice fignant, Ut quo queque modofteterit, quâ parte calores Auftrinos tulerit, que terga obverterit axi Reftituant: Adeo in teneris confuefcere multum eft.}

Geor.li.t. Which Monition, though Pliny, and fome others think good to neglect, or efteem Iudifferent; I can confirm from frequent loffes of my own, and by particular trials; having fometimes Tranf- 


\section{A Difcourge of. Foreit-Trees.}

planted great trees at Mid-fomer with fuccefs (the Earth adhering to the Roots) and mifcarried in others where this Circumeftance only was omitted.

To obferve therefore the coast, and fide of the ftock, efpecially of Fruit-trces) is not fuch a trifle as by fome pretended: For if the Air be as much the Mother or Nuree, as Water and Earth, (as more then probable it is) fuch bloffoming Plants as court the motion of the Meridian Sun, do as 'twere evidently point out the advantage they receive by their pofition: And the frequent $m o \iint_{-1}$ $n e \beta$ of moft Trees on the oppofite fide does fufficiently note the unkindnefs of that $A \int p e c t$; and which is moft evident in the bark of Oaks white and fmooth; The Trees growing more kindly on the South fide of an Hill, then thofe which are expos'd to the North, with an hard, dark, rougher, and more moffe Integument. I have feen (writes a worthy Friend to me on this occafion) whole Hedge-rows of Apples and Pears that quite perifh'd after that thelter was remov'd : The good Husbands expected the contrary, and that the Fruit thould improve, as freed from the predations of the Hedge; but ufe and cuftom made that fhelter neceflary; and therefore (faith he) a ftock for a time is the weaker, taken out of a Thicket, if it be not well protected from all fudden and fierce invalions either of crude Air or Winds: Nor let any be deterr' ${ }^{\prime} \mathrm{d}$, if being to remove many Trees, he fhall efteem it too confumptive of time; for with a $\mathrm{Bruhh}$ dipped in any white colour, or Oaker, a thoufand may be marked as they ftand, in a moment; and that once donc, the difficulty is over. I have been the larger upon thefe two Remarks, becaufe I find them fo mateirial, and yet fo much neglected.

8. There are other Rules concerning the fituation of Trees; the former Autbor commending the Nortb-east-mind bath for the flourifhing of the Tree, and advantage of the Timber; but to my obfervation, in our Climates, where thofe tharp winds do rather flanker then blow fully oppofite upon our Plantations, they thrive beft; and there are as well other Circuinst ances to be confidered,as they refpect Rivers and Marhhes obnoxious to unwholfom and poyfonous Fogs; Hills, and Seas, which expofe them to the weather; and thofe Sylvifragi venti, our cruel, and tedious Western minds; all which I leave to obfervation; becaufe thefe accidents do fo univerfally govern; that it is not eafie to determine farther then that the Timber is commonly better qualified which hath endur'd the colder Afpects without thefe prejudices: And hence it is, that Seneca.obferves Woods moft expos'd to the Winds to be the moft ftrong and folid, and that therefore Chiron made Achilles's Spcar of a Mountain-tree; and of thofe the best which grow thin, not much thelter'd from the North. Again, Theopbrast us feens to have ipecial regard to places; exemplifying in many of Greece, which exceeded others for good Tinzber, as doubtlefs do our Oaks in the Forest of Dean all others of England : and much certainly there may reafonably be attributed to thefe advantages for the growth of Timber, and of almoft all other Trees, as we daily fee by their general 


\section{A Difcourfe of Foreft-Trees.}

general improfperity where the ground is a bot gravel, and a loofe earth : An Oak or Elme in fuch a place thall not in an bundred years overtake one of fifty planted in its proper foil; though next to this, and (haply) before it, I prefer the good Air : But thus have they fuch vaft funipers in Spain; and the Afhes in fome parts of the Levant (as of old neer Troy) fo excellent, as it was after miftaken for Cedar, fo great was the difference; as now the Cantabrian or Spanifh exceeds any we have elfe in all Europe.

9. But before we take leave of this Paragraph, concerning the Tranplanting of great Trees, and to thew what is poffible to be effected in this kind, with coft, and induftry; Count Maurice (the late Governour of Brafil for the Hollanders) planted a Grove neer his delicious Paradife of Friburge, containing fix hundred Cocotrees of eighty years growth, and fifty foot high to the neereft bough : thefe he wafted upon Floats, and Engines, four long miles, and planted them fo luckily, that they bare abundantly the.very firft year; as Gappar Barlaus hath related in his elegant Defcription of that Princes expedition : Nor hath this only fucceeded in the Indies alone; Monfieur de Fiat (one of the Marfhals of France) hath with hige Oaks done the like at de Fiat: Thall I yet bring you neerer home? My Lord Hopton planted Oaks as big as twelve oxen could draw, to fupply fome defect in an Avenue to one of his houfes in Devonfire; as the Right Honourable Sir Charles Barclay, Treafurer of His Majefties Houfhold, affur'd me; -who had himfelf likewife practis'd the Removing of great $0 a k s$ by a particular addrefs extreamly ingenious, and worthy the communication.

10. Chule a Tree as big as your thigh, remove the earth from about him; cut through all the collateral Roots, till with a competent ftrength you can enforce him down upon one fide, fo as to come with your Axe at the Tap-root; cut that off, redrefs your Tree, and lo let it ftand cover'd about with the mould you loofen'd from it, till the next year, or longer if you think good; then take it up at a fit feafon; it will likely have drawn. new tender Roots apt to take, and fufficient for the Tree, whereloever you fhall tranfplant him : Pliny notes it as a common thing, to re-eltabliih huge Trees which have been blown down, part of their Roots torn up, and the body proftrate; and, in pirticular, of a Fir, that when it was to be tranplanted had a tap-root which went no lefs then eight cubits perpendicular; and to thefe I could fuperadd, but I proceed. To facilitate the Removal of fuch monftrous Trees, for the Adornment of fome particular place, or the rarity of the Plant, there is this expedient. A little before the hardeft Frofts furprize you; make a fquare Trench about your Tree, at fuch diftance from the Stem as you judge lufficient. for the Root; dig this of competent depth, fo as almoft quite to undermine it; by placing blocks, and quarters of wood, to fuftain the Earth; this done, caft in as much Water as may fill the Trench, or at leaft fufficiently wet it, unlefs the ground were very moift before. Thus let it ftand; till fome very hard Frost do bind it firmly to the 


\section{A Difcourse of Foreft-Trees.}

Roots, and then convey it to the pit prepar'd for its new ftation; but in cafe the mould about it be foponderous as not to be remov'd by an ordinary force; you may then raife it with a Craine or Pully hanging between a Triangle, which is made of three ftrong and tall Limbs united at the top, where a $P_{u}$ lly is faftned, as the $C_{a-}$ bles are to be under the quarters which bear the earth about the Roots : For by this means you may weigh up, and place the whole weighty clod upon a Trundle to be convey'd, and Replanted where you pleare, being let down perpendicularly into the place by the help of the forefaid Engine. And by this addreß you may Transplant Trees of a wonderful ftature, without the leaft diforder; and many times without topping, or diminution of the bead, which is of great importance where this is practis'd to fupply a Defect, or remove a Grriojity.

II: Some advife, that in planting of Oaks, or. four, or five be fuffer'd to ftand very neer to one another, and then to leave the moft proferous, when they find the reft to difturb his growth; but I conceive it were better to plant them at fuch diftances, as they may leaft incommode one another : For Timber-trees, I would have none neerer then forty foot where they ftand clofeft; efpecially of the fpreading kind.

12. Laftly, Trees of ordinary ftature Tran/planted (being firft well water d) muft be fufficiently ftaked, and $B u / h^{\circ} d$ about with thorns, or with fome thing better, to protect them from the concuffions of the Winds, and from the cafual rubbing, and poyfonous brutting of Cattle and sheep, the oyline $\beta$ of whofe Wooll is alfo very noxious to them; till being well grown, and fixed (which by feren years will be to fome competent degree) they fhall be able to withftand all accidental invafions, but the $A x e$; for I am now come to their Pruning and Cutting, in which work the seafons are of main importance.

13. Therefore, if you would propagate Trees for Timber, cut not off their beads at all, nor be too bufse with lopping: but if you defire shade, and Fuel, or bearing of Maft alone, lop off their Tops, fear, and unthriving Branches only; If you intend an out-right felling, expect till November; for this premature cutting down of Trees before the 'sap is perfectly at rest will be to your exceeding prejudice, by reafon of the Worm, which will certainly breed in the Timber which is felled before that period : But in cafe you cut only for the Cbimney, you need not be fo punctual as to the time; yet for the benefit of what you let $f$ tand obferve the Moons increafe. The Reafon of thefe differences is; becaufe this is the beft feafon for the gromth of the Tree which you do not fell, the other for the durablene $\beta$ of the Timber which you do: Now that which is to be burnt is not fo material for lasting, as the gromth of the Tree is confiderable for the Timber.

$\therefore$ 14. The very fumps of $0 a k$, efpecially that part which is $d r y$, and above ground being well grubb'd, is many times worth the pains and charge, for fundry rare, and hard works; and where Timber is dear: but this is to be practis'd only where you 
defign a final extirpation; for fome have drawn fuckers even from an old $f u b$-root; but they certainly perin by the Moß which in: vades them, and are very fubject to grow rotten. Pliny fpeaks of one Root which took up an entire Acre of Ground; if fo, his Argument may hold good, for their growth after the Tree is come to its period.

15. There is not in nature a thing more obnoxious to deceit; then the buying of Treesftanding, upon the reputation of their Appearance to the eye, unlefs the Cliapman be extraordinarily judicious; fo various are their bidden, and conceal'd Infirmitics, till they be fell' $d$, and fawn out : fo as if to any thing applicable, certainly there is nothing which does more perfectly confirm it then the moft flourifhing out-fide of Trees, Fronti nulla fides. A Timber-tree is a Merchant Adventurer, you thall never know what he is worth, till he be dead.

I6. Oaks are in fome places (where the foil is pecially qualified) ready to be cut for Cops in fourteen years and fooner; I compute from the firt femination; though it be told as an inftance of high encouragement (and as indeed it merits) that a Lady in Nortbamptonßire fowed Acorns, and liv'd to cut the Trees produc'd from them, twice in two and twenty years; and both as well grown as mot are infixteen or eighteen. This yet is certain, that Acorns fet in Hedge-rows have in thirty years born a ftem of a foot diametre. Generally, Copps-wood thould be cut clofe, and at fuch Intervals as the grow th requires; which being feldom conftant, depends much on the places, and the kinds, the mould and the air, and for which there are extant particular statutes to direct us, of all which more at large hereafter. Oak for Tan-barkmay be fell'd from April to the laft of Fane, by a Statute in the I Jacobi.

17. To enumerate now the incomparable $V \int e s$ of this Wood; were needlefs : But fo precious was the efteem of it, that of olst there. was an exprefs Law amongft the Twelve Tables concerning the very gathering of the Acorns though they fhould be found fallen into another mans Ground: The Land and the Sea do fufficiently fpeak for the improvement of this excellent material; Honfes, and Ships, Cities and Navies are built with it; and there is a kind of it fo tough, and extreamly compact, that our fharpeft Tools will hardly enter it, as fcarcely the very Fire it felf, in which it confumes but flowly, as feeming to partake of a ferruginows, and metallin fhining nature proper for fundry robuft lifes. That which is twin' ${ }^{\circ}$, and a little wreathed (eafily to be difcern'd by the texture of the Bark) is beft to fupport Burthens, for 'Pofts, Co: lumns, summers, \&uc. for all which our Englifh Oak is infinitely. preferrable to the French, which is nothing to ufeful, nor comparably fo ftrong; infomuch as I have frequently admir'd at the fudden failing of moft goodly Timber to the Eye, which being impluy'd to thefe $v$ fes does many times moft dangeroufly flie in funder, as wanting that native $\beta$ ring, and toughne $\beta_{\text {, which our Englifs }}$ Oak is indu'd withall. For shingles, Pales, Lathes, Coopers ware, clap-board, \&uc. the fmalleft and ftraighteft is beft; difcover'd 
likewife by the upright tenor of the Bark, as being the meft proper for cleaving: The knottieft for Water-morks, Piles and the like; becaufe 'twill drive beft, and laft longert. Were planting of thefe Woods more in ufe, we thould banifh our boops of $\mathrm{Hafel}$, \&uc. for thofe of good Oak, which being made of the younger fhoots, are excceding tough and frong: One of them being of Ground Oak will out-laft $\int i x$ of the beft $A$ fh. The fmaller trunchions, and $\beta$ ray, make Billet, Bavine and Coals; and the very Bark is of price with the Tanner and Dier, to whom the very Sam-duft is of ufe, as are the Afles and Lee to cure the roapiflneß of Wine.The Ground-Oak while young is us'd for Poles, Cudgels and Walking-ftaffs, not to forget the Galls, Miffletoe, and many other ufeful Excrejcencies : Pliny affirms that the Galls do break out altogether in one night about the beginning of $7 u n e$, and arrive to their full growth in one day; this I recommend to the experience of fome extraordinary vigilant Wood-man. What benefit the Maft does univerfally yield for the fatting of Hogs and Deer I hall thew upon another occafion, before the conclufion of this Difcourfe; in the mean time, the very Acorns themfelves were heretofore the Food of Men (as well as other Productions of the earth) till their luxurious Palats were debauched; and even in the Romans time, the cuftom was in Spain to make a fecond fervice of Acorns and $M a f t$, (as the French now do of Marrons, and $C h e(\beta-n u t s)$ which théy likewife ufed to roft under the embers. Oaks bear alfo a knur, full of a Cottony matter, of which they Antiently made Wick for their Lamps and Candles; and among the selectiora Remedia of Fo. Pravotius there is mention of an Oyl c̀ quernaglande Chymically extracted, which he affirmes to be of the longelt continuance, and leart confumptive of any others whatfoever, for fuch lights, ita ut uncia fingulis menfibus vix abfumatur continuo igne. To conclude, M. Blith makes spars and fmall building Timber of Oakes of eleven years growth; this is indeed a prodigious Advance, but I fufpect the figure.

\section{CHAP. IV. \\ of the Elm.}

Elm. I. F the Elm there are four, or five forts, and from the difference of the soil and Air divers $\beta$ urious : Two of thefe kinds are moft worthy our culture, viz. the Monntaite Elm, which is taken to be the Oriptelea of Theophraftus; being of a lefs, jagged and fmaller leaf; and the Vernacula or Trench Elm, whofe leaves are thicker, and moreflorid, delighting in the lower, and moifter grounds, where they will fometimes rife to above an hundred toot in height, and a prodigious growth, in lefs then an Age; my felf having feen one planted by the hand of a 
Counte $\beta$ yet living, which is neer twelve foot in compajs, and of an beight proportionable; notwithfanding the numerous progeny which grows under the thade of it, fome whereof are at leaft a foot in Diameter, that for want of being feafonably tranjplanted muft needs have hindered the procerity of their ample and indulgent Mother.

2. Both thefe forts are rais'd of Appendices or Suckers (as anon we Thall defcribe) but this latter comes well from the samera or Seeds, which being ripe about the beginning of March will produce them; as we fee abundantly in the Gardens of the Thuylleries, and that of Luxembourg, at Paris, where they ufually fow themfelves, and come up very thick; and fo do they in many places of our Country, though fo feldom taken notice of, as that it is efteem'd a Fable by the lefs obfervant and ignorant Vulgar. To raife them therefore of their seeds (being well dry'd a day or two before) fprinkle it in Beds prepar'd of good earth; fiefting fome of the fineft mould thinly over them, and watering them when need requires. Being rifen an inch above ground (refreth'd, and preferv'd from the fcraping of Birds and Poultry) comfort the tender reedlings by a fecond fiefting of more fine earth, to eftablifh them; thus keep them clean weeded for the firft two years; or till being of fitting ftature to Remove, you may tbin, and Tranßplant thein in the fame manner as you were directed for young oaks; only they Thall not need above one cutting where they grow lefs regular and hopeful. But becaufe this is an Experiment of fome curiofity, obnoxious to many cafualties; and that the producing them from the .Mother-roots of greater Trees is very facile and expeditious (befides the numbers which are to be found in the Hedge-rows, and Woods, of all plantable fizes) I rather advife our Forefter to furnifh himfelf from thofe places.

3. The suckers which I fpeak of are produc'd in abundance from the Roots, whence being dextroully feparated, after the Earth has been well loofen'd, and planted about the end of ocfo: ber, they will grow very well : Nay, the ftubs only, which are left in the ground after a Folling (being fenced in as far as the Roots extend) will furnith you with plenty, which may be Tranfplanted from the firft year or two fucceftively, by flipping thein from the Roots, which will continually fupply you for many years after that the body of the Mother Tree has been cut down: And from hence probably is fprung that (I fear) miftake of 'salmafius and others, where they write of the growing of their chips (I fuppofe, having fome of the bark on) featter'd in hewing of their Timber; the Errour proceeding from this, that after an Elm-tree has been Fell'd, the numerous suckers.which thoot from the remainders of the latent Roots feem to be produced from this difperfion of the chips : Let this yet be more accurately'examin'd; for I pronounce notling Magifterially.

4. But there is alfo another Artifice to produce them fooner, which is this; Bare fomc of the Mafter-roots of a vigorous Tree, within a foot of the Trunk, or thereabouts, and with your Axe 
tnake feveral chops, putting a fmall ftoric into every cleft, to hinder their clofure, and give accefs to the wpet; then cover them with three or four inch thick of Eartb: and thus they will fend forth sssckers in abundance, which after two, or three Years, you may feparate, and plant in the Vlmarism, or place defign'd for them; and which if it be in plumps (as they call them) within ten or twelve foot of each other, or in Hedge-roms, it will be tlie better: For the Elm is a Tree of Confort, Sociable, and fo affecting to grow in Company, that the very beft which I have ever feen do almoft touch one another : This alfo protects them from the Winds, and caufes them to thoot of an extraordinary beight; fo as in litthe more then forty years they even arrive to a load of Timber; provided they be feduloufly and carefully cultivated, and the foil propitious. For an Elm does not thrive fo well in the Foreft, as where it may enjoy fcope for the Roots to dilate and fpread in the fides, as in Hedge-roms and Avenues, where they have the Air likewife free.

5. Of all the Trees which grow in our Woods, there is none which does better fuffer the Tranplantation then the Elm; for you may remove a Tree of twenty years growth with undoubted luccefs : It is anExperiment $I$ have made in a Tree alınoft as big more as my wafte; but then you muft totally disbranch him, leaving only the Summit intire; and being careful to take him up with as much Earth as you can, refrefh him with abundance of water. This is an excellent and expeditious way for great Perfons to plant the Acce/Jes of their Honfes with; for being difpos'd at fixteen, or eighteen foot Interval, they will in a few years beargood. ly beads, and thrive to admiration. Some that are very cautious emplafter the wounded head of fuch over-grown Elms with a mixture of clay, and bor $e$ e-dung, bound about them with a waip of Hay or fine Mofs, and I do not reprove it. But for more ordinary plantations, younger Trees, which have their bark fmooth and tender, about the fcantling of your leg, and their beads trimm'd at five or $f(x$ foot beigbt, are to be preferr'd before all other. Cato would have none of thefe forts of Trees to be removed till they are five or fix fingers in diameter; others think they cannot take them tooyoung; but experience (the beft Mistriß) tells $w$, that you can hardly plant an Elm too big. There are who pare away the Root within two fingers of the ftem, and quite cut off the Head; but I cannot commend this extream feverity, no more then I do the Atrewing of Oats in the pit; which fermenting with the moifture, and frequent materings, is believed much to accelerate the putting forth of the Roots; not confidering, that for want of air they corrupt, and grow mujty, which more frequently fuffocates the Roots, and endangers the whole Tree.

6. The Elms delights in a found, freet and fertile Land, fomething more inclin'd to moifture, and where good Pafture is produced; though it will alfo profper in the gravelly, provided there be a competent depth of mould, and be refrefh'd with fprings:in defect of which, being planted on the very furface of the ground (the 
Swarth par'd firft away, and the earth ftirred a foot deep or more) they will undoubtedly fucceed; but in this Trial, let the Roots be handfomly fpread, and covered a foot, or more in height, and above all, firmly ftaked. This is practicable alfo for other Trees, where the Soil is over moift, or unkind: For as the Elm does not thrive in too $d r y$, fandy or bot grounds, no more will it abide the cold and $\beta$ pungy; but in places that are competently fertile, or a little elevated from thefe annoyances; as we fee in the Mounds, and caftings up of ditches, upon whore banks the Femal fort does more naturally delight.

7. The Elm is by reafon of its afpiring, and tapering growth (unlel's it betopp ${ }^{\circ} d$ to enlarge the branches, and make them fpread low) the leaft offenfive to Corn, and Pafture-gromnds, to both which, and the Cattel, they afford a benign Shade, defence, and agreeable Ornament.

8. It would be planted as foullow as might be; for, as we noted, deep interring of Roots is amongft the CatbolickMiftakes; and of this, the greatest to which Trees are obnoxious. Let new planted Elms be kept moist by frequent refrelhings upon fome half-rotten Fern, or Litter laid about the foot of the jtem; the earth a little ftirred and depreffed for the better reception, and retention of the water.

9. Laftly, your Plantation muft above all things be carefully preferv'd from Cattel, and the concuffions of impetuous Winds, till they are out of reach of the orie, and fturdy enough to encounter the other.

10. When you lop the Elm (which may be about fanuary for the fire, and more frequently, if you defire to have them tall; or that you would form them into Hedges (for fo they may be kept plaßsed, and thickned to the higheft twig; affording both a magnificent, and auguft Defence againft the Winds and Sun) I fay', when you thus trim them, be careful to indulge the Tops; for they protect the body of your Trees from the wet, $^{2}$ which always invades thofe parts firft, and will in time perifis them to the very heart; fo as Elms beginning thus to decay, are not long profperous. Sir Hugh rlat relates (as from an expert Carpenter) that the boughs and branches of an Elm thould be left a foot long next the trunk, when they are $l o p^{\circ} d$; but this is to my certain obfervation a very great miftake either in the Relator, or Author: for I have noted many Elmss fo difbranch'd, that the remaining Jtubs grew immediately bollow, and were as fo many Conduits, or Pipes, to hold, and convey the Rain to the very body, and beart of the Tree.

II. There is a Cloyfter of the right French Elm in the little Garden neer to her Majefties the 2. Mothers Chaprel at somerfet-houf $e_{4}$ which were (I fuppofe) planted there by the induftry of the FF. Capucbines, that will perfectly ditect you to the incomparable ufe of this noble Tree for fhade and delight, into whatever Figure you will accuftom them. I have alfo heard of graffing Elms to a great improvement of their heads, and it, would be try'd. 
12. When you would Fell let the sap be perfectly in repofe; as 'tis commonly about Novenaber or December, after the froft hath well nipp d them: I have already alleadg'd my reafon for it; and I am told, That both Oak and Elm fo cut, the very saplings (whereof Rafters, Spars, \&c. are made) will continue as long as the very beart of the Tree without decay. In this roork cut your kerfo near to the ground; but have a care that it fuffer not in the fall, and be ruined with its own weight: This depends upon your Wood-man's judgment in disbranching, and is a neceffary caution to the Felling of all other Timber-Trees. If any begin to doat, pick out fuch for the $A x$, and rather truft to its succeffor.

13. Elm is a Timber of moft fingular $v \int e$; efpecially where it may lie continually dry, or wet in extreames; therefore proper for Water-works, Mills, Pipes, Pumps, ship-planks beneath the Waterline; and fome that has been found buried in Boggs, has turn'd like the moft polin'd, and hardeft Ebony, only difcern'd by the grain: Alfo for Wheel-mrights, Kerbs of Coppers, Featheridg and Weather-boards, Dre]jers and fundry other imployments. It makes alfo the fecond fort of charcoal; and finally (which I muft not omit) the ufe of the very leaves of this Tree, efpecially of the female, is not to be defpis'd; for being fuffered to dry in the Sun upon the Branches, and the $\beta$ ray fhrip'd off about the decreafe in Auguft (as alfo where the fuckers and ftolones are fuper-numerary, and hinder the thriving of their Nurjes) they will prove a great relief to Cattel in Winter, when bay and fodder is dear; they will eat them even before Oates, and thrive exceedingly well with them; remember only to lay your Boughs up in fome dry, and fweet corner of your Barn: It was for this the Poet prais'd them, and the Epithete was advis'd,

\section{_- frecunde frondibus vlmi. Georg. 2.}

In fome parts of Hereford-Sire they gather them in sacks for their swine, and other Cattel according to this husbandry.

\section{CHAP. V. \\ Of the Beech.}

Beecb. $\quad 1.7$ He Beech, [Fagus $]$ numbred amongft the glandiferous Trees, 1 I rank here before the martial $A h_{\text {, }}$, becaufe it commonly grows to a greater fature. There are of thefe $F$ agi two, or three kinds with us; the Mountain, which is the whitert, and moft fought after by the Turner; and the Campeftral or wild, which is of a blacker colour, and more durable. They are both to be rais'd from the Maft, and govern'd like the Oak, of which amply; and that is abfolutely the beft way of furnifhing a Wood: But they are likewife 


\section{$A$ Difcourfe of Foreft-Trees.}

likewife to be planted of young feedlings to be drawn out of the places where the fruitful Trees abound. In Tranplanting them cut uffonly the boughs and bruifed parts, two Inches from the ftem, to within a yard of the top; but be very fparing of the Root: This for fuch as are of pretty ftature. They make fpreading Trees, and noble shades with their well furnifh'd and gliftering leaves, being fet at forty foot diftance; but they grow taller and more upright in the Forefts, where I have beheld them at eight and ten foot, Shoot into very long poles; but neither fo apt for Timber, nor Fuel: In the Vallies (where they ftand warm, and in confort) they will grow to a ftupendious procerity, though the foil be ftony and very barren: Alfo upon the declivities', fides and tops of high Hills, and chalkie Mountains cfpecially; for they will ftrangely infinuate their Roots into the bowels of thofe feemingly impenetrable places, not much unlike the Fir it felf, which, with this fo common Tree, the great Cafar denies to be found in Britanny, Materia cujufque generis, ut in Gallia, prater Fagum of abietem : but certainly from a grand miftake.

2. The Beech ferves for various Vfes of the Houfe-roife; with it the Turner makes Difhes, Trays, Bowls; Rimbs for Buckets, and other Utenfils, Trencbers, Drefer-boards, Euc. likewife for the Wheeler, Foyner, and Upholster for Sellyes, chairs, Stools, Bed-fteads, Erc. for the Bellows-maker, and Husbandman his shovel and Spade-graffs; for Fuel, Billet, Bavin and Coal though one of the leaft latting: Not to omit even the very shavings for the fining of Wines. . Of old they made their Vafa Vindimiatoria and Corbes Mefforie (as we our pots for Strano-berries) with the Rind of this Beech; and that curioufly wrought Cup which the shepherd in the Bucolicks wagers with all, was engraven by Alcimedon upon the Bark of this Tree : You would not wonder to hear me deplore the fo frequent ufe of this Wood, if you did confider that the induftry of France furnifhes that Country for all domeftic Vtenfils with excellent $W$ all$n u t$; a material infinitely preferrable to the beft Beech; which is indeed good only for frade and for Fire; as being brittle, and exceedingly obnoxious to the Worm: But whil'ft we thus condemn the Timber, we muft not omit to praife the Mast, which fats our swine and Deer, and hath in fome Families even fupported men with bread: Chios indur'd a memorable siege by the benefit of this Maft : and in fome parts of France they now grind the Buck in Mills; it affords a fweet $O y l$ which the poor people eat moft willingly: But there is yet another benefit which this Tree prefents us; that its very leaves which make a natural, and moft agreeable Canopy all the Summer; being gather'd about the fall, and fomewhat before they are much froft-bitten, afford the beft and eafieft Mattreffes in the world to lay under our quilts inftead of fram; becaule, befides their tendernefs and loofe lying together, they continue fweet for feven or eight years long; before which timeftram becomes musty, and hard; They are thus ufed by divers perfons of 2uality in Dauphine, and in Swizzerland I have 
fometimes lain on them to my great refrefhment : fo as of this Tree it may properly be faid,

-Sylvadomus, cubilia frondes. Juvenal.

Swint may be driven to Mast about the end of Angust.

\section{CH A'P. VI.}

$$
\text { of the } A j \text {. }
$$

Aho. I. Rnus the $A / h$ is with us Male and Female, the one affecting the higher grounds :

\section{Steriles faxofis montibus orni. Geor. 2.}

The other the plains, of a mbiter wood, and rifing many times to a prodigious ftature; fo as in forty years from the $K e y$, an $A / b$ hath been fold for thirty pounds sterling : and I have been credibly inform'd, that one perfon hath planted fo much of this one fort of Timber in his life time as hath been valu'd worth fifty thousand pounds to be bought. Thefe are pretty encouragements, for a fmall, and pleafant induftry.

2. The Keys being gather'd when they begin to fall (which is about the end of october, and the enfuing Moneth) are to be fow'd; but not altogether fo deep as your former Masts: Thus they do in Spain: A very narrow seminary will be.fufficient to ftore an whole Country: They will lye a full year in the ground before they appear; therefore you muft carefully Fence them all that time and have patience: But if you would make a confiderable Wood of them at once, Dig or Plow a parcel of ground, as you would prepare it for Corn, and with the Corn (or what other Grain you think fitteft) fow alfo good ftore of Keys, fome Crabkernels, Euc. amongit them : Take off your crop of Corn, or Seed in its Seafon, and the next year following it will be cover'd with young $A$ fhes, which will be fit either to ftand, or be Tran $\beta$ lanted for divers years after; and thefe you will find to be far better then any you can gather out of the Woods (efpecially suckers which are worth nothing) being removed at one foot ftature (the fooner the better) provided you defend them well from Cattel: The reafon of this hafty tranfplanting, is to prevent their obftinate, and decp rooting ; tant us amor terra which makes them hard to be taken up when they grow older, and that being remov'd, they take no great hold till the fecond year, after which they come away amain : Yet I have planted them of five and fix inches diametre, which have thriven as well as the fmaller wands. 


\section{A Difcoirse of Foreft-Trees.}

Cut not his Head at all, nor (by any means) the fibrous part of the Roots, only, that down-right, or Tap-root (which gives our Huf: bandmen fo much trouble in drawing) is to be totally abated : But this work ought to be in the increafe of offober, or $\mathrm{No}^{+}$ vember, and not in the spring. We are (as I told you) willing to fpare his head; becaufe, being yet young, it is but of a pongy fubftance; but being once well fixed, you may cut him as clofe to the earth as you pleafe; it will caufe him to hoot prodigioufly; fo as in a few years to be fit for Pike-ftaves. In South spain (where are the beft) after the firft Jreffing, they let them grow till they are fo big, as being cleft into four parts, each part is fufficient to make a Pike.Jtaff: I am told there is a Flemifh Afh planted by the Dutch$m e n$ in Lincolnflire, which in fix years grows to be worth twenty frillings the Tree; but I am not affur'd, whether it be the $A$, $h$, or Abeele; either of them were, upon this account, a worthy encouragement. From thefe low Cuttings come our Ground-afhes, fo much fought after for Arbours, Epailiers, and other Pole-Works: They will fpring in abundance, and may be reduced to one for a standard-tree, or for Timber, if you defign it $;$ for thus, Hydra like, a Ground-cut-aflo

Per damina, percades, ab ipfo

Ducit opes animímǵs ferro. Hor.

3. It is by no means convenient to plant $A / h$ in Plono-lands; for the Roots will be obnoxious to the Coulter; and the frade of the Tree is malignant to Corn when the head and banches over-drip it; but in Hedge-rows, and Plumps, they will thrive exceedingly; where they may be difpos'd at nine or ten foot diftance, and fometimes neerer : But in planting of a whole Wood of feveral kinds of Trees for Timber, every third fet at leaft would be an $A f_{\text {. }}$. The beit $A f h$ delights in the beft Land (which it will foon impoverifh) yet grows in any ; fo it be not over-wet, and approaching to the Marfhy, unlefs it be firft well drain'd: By the banks of fweet and cryftal Rivers and Streams I have obferv'd them to thrive infinitely.

4. The ufe of $A \beta$ is (next to that of the Oak it felf) one of the moft univerfal : It ferves the Souldier \& Fraxinus utilis baftis. Ovid. The Carpenter, Wheel-wright, Cart-wright, Cooper, Turner and Thatcher: Nothing like it for our Garden Palifddbedges, Hop-yards, roles and Spars, Handles, stocks for Tools, spade-trees, \&uc. In fum, the Husband-man cannot be without the $A$ fo for his $C$ arts, Ladders, and other tackling: From the Pike, spear and Bow (for of $A f b$ were they formerly made) to the Plon ; in Peace and War it is a wood in highelt requeft: Laftly, the white and rotten dottard part compófes a ground for oúr Gallants Sweet-powder, and the Truncheons make the third fort of the moft durable Coal, and is (of all other) the fweeteft of our Foreft-fuelling, and the fitteft for Ladies Chambers: To conclude, the very dead-leaves afford (like thofe of the Elm) relief to our Cattel in 
Winter; but the thade of them is not to be endur'd, becaufe it produces a noxious Infect; and for difplaying themfelves fo very late, and fulling veryearly, not to be planted for Umbrage, or Ornament; efpecially neer the Garden; fince (befides their predatitious Roots) the deciduous leaves defcending with fo long a stalk, are-drawn by clufters into the Worm-boles, which foulthe Allies with their falling $K c y$ s, and fuddenly infect the ground.

\section{CHAP. VII. \\ Of the Cheß-nut:}

Cbessenut.

I. We next is the Cbeß-nnt, [Caftanea] of which Pliny reckons many kinds, efpecially that about Tarentum and Naples; but we commend thofe of portugal. They are rais'd beft by fowing; previous to which, let the Nuts be firft fpread to freat, then cover them in fand; a Moneth being paft, plunge them in Water, reject the swimmers; being dry'd for thirty days more, fand them again, and then to the water-ordeal as before. Being thus treated till the beginning of spring, fet them as you would do Beans: rliny will tell you they come not up, unlefs four or five be pil'd sogether in a hole; but that is falfe, if they be good, as you may prefume all thofe to be which pars this examination; nor will any of them fail: But being come up they thrive beft unremovid, making a great $f$ and for at leaft two years ufon every Tranjplanting; yet if needs you muft alter their station, let it be done about November, and that into a light friable ground, or moift Gravel; however, they will grow even in Clay, sand, and all mixed foils, upon expos'd and bleak places, as more patient of cold then heat.

2. If you defire to fet them in Winter, or Autumn, I counfel you to inter them within their husks, which being every way arm'd are a good protection againft the Mou $\sqrt{e}$, and a providential integument : Some fow them confufedly in the Furrom like the Acorn, and govern them as the Oak; but then would the ground be broken up 'rwixt November and February; and when they fpring be cleinfed at two font afunder, after two years growth : Likewife may copjes of Cheß-nuts be wonderfully increafed and thickn'd by laying the tender and young branches; but fuch as fpring from the Nuts and Marrons are beft of all, and will thrive exceedingly, if being let ftand without removing, the ground be firr'd and loolen'd about their Roots for two or three of the firft years, and the fuperfluous wood pruned away: Thus will you have a copje ready for a felling within cight years, which (befides many other ufes) will yield you incomparable poles for any work of the Garden, Vineyard, or Hop-yard, till the next cutting: And if the Treellike the ground, will in ten or twelve 
years grow to a kind of $T$ imber, and bear plentiful fruit.

3. I have feen many Cheß-nut-trees tranfplanted as big as my arm, their beads cut off at five and fix foot height; but they came on at leifure: In fuch $p$ lantations, and all others for Avenues, you may fet them from thirty to ten foot diftance, though they will grow much neerer, and thoot into poles, if (being tender) you cultivate them like the $A$ h.

4. The cheß-nut being graffed in the Wall-nut, Oak or Beerh, (Ihave been told) will come exceeding fair, and produce incomparable Fruit; for the $W$ all-nut it is probable; but I have not as yet made a full attempt: In the mean time, I wilh we did more univerfally propagate the Horfe-che $\beta$-nut, which being eafily increas'd from layers grows into a goodly standard, and bears a moft glorious flower, even in our cold Country : This Tree is now all the mode for the Avenues to their Countrey palaces in France, as appears by the late superintendents Plantation at Vaux.

5. The ufe of the cheß-nut is (next the Oak) one of the moft fought after by the Carpenter and foyner : It hath formerly built a good part of our ancient houfes in the City of London, as does yet appear. I had once a very large Barn neer the City fram'd intirely of this Timber: And certainly they grew not far off; probably in fome Woods neer the Tonn: For in that defcription of London written by Fitz-Stephens, in the Reign of Hen. 2. he fpeaks of a very noble and large Foreft which grew on the Boreal part of it: Proxime (fayshe) patet forefta ingens, faltus nemorofi ferarum, latebre cervorum, damarum, aprorum, Gutaurorum sylveltrium, o.c. a very goodly thing it feems, and as well ftor'd with all forts of good Timber, as with Venifon and all kind of $C b a f e$. The $C h e \beta-n u t$ affords the belt Stakes and Poles for Palifades and Hops, as I faid before; and being planted in Hedge-rows o circa agrorum itinera, or for Avenues to our Country-boufes, they are a magnificent and royal Ornament : But we give that fruit to our Smine in England, which is amongt the delicaces of Princes in other Countries; and. being of the larger Nut, is a lufty, and mafculine food for Ruftics at all times. The beft Tables in France and Italy make them a fervice, eating them with Salt, in Wine, being firft rofted on the chapplet; and doubtlefs we might propagate their ufe, amongft our common people, at left (as of old the Baravopáyos) being a Food. fo cheap, and folafting. Finally,

\section{CHAP. VIII.}

$$
\text { of the Wall-nut. }
$$

I. THe Wall-nut is to be elevated like the cheßs-nut, being Wall-nxt. 1 planted of the Nut, or fet at the diftance you would 
have him ftand; for which they may be prepared by bedding them (being dry) in $\int a n d$, or good earth, till March, from the time they fell, or were beaten off the Tree: Or if before they be fet with busk and all upon them; for the extream bitternefs thereof is moft exitial and deadly to worms: Some fupple them a little in warm Coms-milk; but being treated as before, you will find them already Jprouted, and have need only to be planted where they are to abide; becaufe (as we faid long fince) they are moft impatient of tranplanting: But if there be an abfolute neceftity of removing, let your Tree be about four years old, and then by nomeans touch the bead with your knife, nor cut away fo much as the very Tap-root; fince being of a pithy and hollow fubfance, the leaft diminution, or bruife, will greatly endanger the killing.

2. The Wall-nut delights in a dry, found and rich land; efpecially, if it incline to a feeding Chalk, or Marle; and where it may be protected from the cold; as in great Pits, Vallies, and Highway fides; alfo in Stony-grounds, and on Hills efpecially Chalkie : likewife in Corn-fields: Thus Burgundy abounds with them, where they ftand in the middeft of goodly Wheat-lands at fixty and an hundred foot diftance; and it is fo far from hurting the crop, that they look on them as a great preferver, by keeping the grounds warm; nor do the roots hinder the Plow. When ever they fell a Tree (which is only the old, and decay'd) they always plant a young one neer him; and in feveral places 'twixt Hanaw and Francfort in Germany, no young Farmer whatfoever is permitted to Marry a Wife, till he bring proof that he hath planted, and is a Father of fuch a fated number of Wall-nut-trees, as the Law is inviolably obferved to this day for the extraordinary benefit which this Tree affords the Inbabitants: And in truth, were this Timber in greater plenty amongftus, we fhould have farbetter Vtenfiles of all forts for our houres, as Chairs, stools, Bed-steads, Tables, Wainfcot, Cabinets, Erc. in ftead of the more vulgar Beech, fubject to the worm, weak and unfightly.

3. They render molt graceful Avenues to our Country dwellings, and do excellently in bedge-rows; but had need be planted at forty, or fifty foot interval; for they affect to fpread both their roots and branches. The Bergftras (which extends from Heidelberg to Darmitadt) is all planted with Wall-nuts; for fo by another ancient Law the Bordurers were oblig'd to nurfe up, and take care of them; and that chiefly for their ornament and thade; fo as a man may ride for many miles about that Country, under a continu'd Arbour, or Clofe-walk; The Traveller both refrefh'd with the Fruit, and the shade: How would fuch publick Plantations improve the glory and wealth of a Nation! but where fhall we find the $\beta$ irits amongft our Country-men? Yes, I will adventure to inftance in thofe Plantations of Sir Richard Stidolph, upon the Downs neer Lether-bead in Surrey; and fo about CaJjaulton, where many thoufands of thefe Irees do celebrate the industry of the owners; and will certainly reward it with infinite improvement, as I am affur'd they do in part already, and that very confiderably; 
befides the ornament which they afford to thofe pleafant Traits, for fome miles in circumference. I remember Monfieur sorbiere, in a sceptical difcourfe tó Monfienr de Martel, fpeaking of the readinefs of the People in Holland to furnifh, and maintain whatfoever may conduce to the publick Ornament, as well as Convenience; tells us, that their Plantations of thefe, and the like Trees even in their very Roads and common High-poays are better preferv'd, and entertain'd (as I my felf have likewife been often an eye witne(s) then thofe about the Houfes and Gardens of pleafure belonging to the Nobles and Gentry of moft other Countries: And in effect it is a mort ravifhing object to behold their amenities in this particular : With us fays he (fpeaking of France) they make a jeft at fich political Ordinances, by ruining thefe publick and ufeful Ornaments, if haply fome more prudent Magijtrate do at any time introduce them. Thus in the Reign of Henry the fourth, during the Superintendency of Monfieur de Sulli, there was a refolution of adorning all the High-ways of France with Elms, orc. but. the rude and milchievous Payfans did fo hack, fteal, and deftroy what they had begun, that they were forc'd to defilt from the through profecution of the defign; $f_{0}$ as there is nothing more expos'd, wild, and lefs pleafant then the common Roads of France for want of $\int \mathrm{s} a \mathrm{de}$, and the decent limits which thefe fweet, and divertiflant Plantations would have afforded; not to omit that Political ufe (as my Lord Bacon hints it where he fpeaks of the statues, and Monuments of brave men, and fuch as hadiwell deferv'd of the Publick, erected by the Romans even in their Highways,) fince doubtlefs, fuch noble and agreeable objects would exceedingly divert, entertain and take off the Minds and Difcourfes of Melancboly people, and penfive Travellers, who having nothing but the dull and enclos'd ways to caft their eyes on, are but ill Converfation to themfelves, and others.

4. What univerfal ufe the French make of the Timber of this fole Tree for domeftic affairs may be feen in every room both of poor and rich: It is of fingular account with the Foyner, for the beft grain'd and colour'd Wain-fcot; with the Gun-fmith for Stocks; the Drum-maker for rimbs: the Cabinet-maker for Inlayings, efpecially the firm and clofe Timber about the Roots, which is admirable for fleckid and cbambletted works, and the older. it is, the more eftimable ; but then it fhould not be put in work till throughly feafon'd; becaufe it will thrink beyond expectation: Befides thefe ufes of the Wood, the Fruit is for preferves, for $0 y l$ and Food; and the very hufks and leaves being macerated in warm water, and that liquor poured on the Carpet of Walks and Bowling-greens, does infallibly kill the Worms without endangering the grafs; not to mention the Dye which is made of this Lixive to colour Wooll, Woods, and Hair, as of old they us'd it. That which is produc'd of the thick hell becomes beft Timber; that of. the thinner, better Fruit. Columella has fundry excellent rules how to afcertain, and accelerate the growth of this Tree, and to improve its qualities, which I recommend to the farther Induftrious, and pars now to the lesprincipal. $\quad F_{2}$ CHAP, 


\section{CHAP. IX.}

\section{of the Service.}

Scrvice. I. THe Service-tree is rais'd of the sorbs, or Berries, which 1 being ripe (that is) rotten about september, may be fown like Beech-maft : It is reported that the soper never fees the fruit of his labour; either for that it bears only being very old; or that Men are commonly $\int 0$ before they think of planting Trees: But this is an egregious miftake; for thefe come very foon to be Trees, and being planted young thrive exceedingly; I have likervife planted them as big as my arm fuccefsfully : The beft way is therefore to propagate them of suckers or Sets; they delight in reafonable good ground, rather inclining to cold then over hot; for in places which are too dry they never bear kindly.

2. The Timber is ufeful for the foyner, and being of a very delicate Grain, for divers curiofities: Alfo it is taken to build with, yielding Beams of confiderable fubftance : The thade is beautiful for Walks, and the Fruit not unpleafant, and in fome cafes aledicinal.

CHA P. X.

Of: the Maple.

Muple. I. THe Maple [Acer ] (of which Authors reckon very many 1 kinds) was uf old held in equal eftimation almoft with the Citron; efpecially the Brufcum, the French-Maple, and the Peacockstail-Maple, which is that fort fo elegantly undulated, and crifped into variety of curles: They are all produced of the Keys, like the $A / B ;$ and like to it, affect a found and a dry mould; growing both in Woods and Hedge-roms, efpecially in the latter; which if rather hilly then low affords the faireft Timber. By fhreading up the boughs to a head I have caus'd it to hoot to a wonderful height in a little time; but if you would lop it for the Fire, let it 2. bedone in fanuary. The Timber is far fuperiour to Beecb for all ufes of the Turner, who feeks it for Difbes, Trays, Trenchers, \&c. as the Goyner for Tables, Inlayings, and for the delicatene's of the grain when the knurs and nodofities are rarely diapred, which does much advance its price : Alfo for the lightnefs (under the name Ayer) imploy'd often by thofe who make Mufical-inftruments. But there is a larger fort, which we call the sycamor. 


\section{CHAP. XI. \\ Of the Sycamor.}

1. THe sycamor is much more in reputation for its ßhade then Sycamor.

it deferves; for the Leaves which fall early (like thofe of the $A$ (f) ) turn to a Mncilage, and putrifie with the firft moifture of the feafon; fo as they contaminate and mar our Walks, and are therefore (by my confent) to be banifh'd from all curious Gardens and Avenues: There is in Germany a better fort of sycamor then ours, wherewith they make saddle-trees, and divers other things of ufe; our own is excellent for Cart and Plow-timber, being light, tough, and not much inferiour to $A \beta$ it felf.

f

\section{CHAP. XII.}

\section{Of the Horn-Beam.}

1. THe Horn-beam, in Latine the Carpinus, is planted of sets; Horn-bealmo

1 though it may likewife be railed from the seeds, which being mature in Auguft fhould be fown in October; but the more expeditious way, is, by sets of about an inch diametre, and curt within half a foot of the Earth: Thus it will advance to a confiderable Tree. The places it chiefly defires. to grow in are in cold hills, and in the barren and moft expos'd parts of Woods.

2. Amongft other ufes which it ferves for, as Mills (for which it excels either Yew or Crab) roak-timber (whence of old 'twas call'd Swia) beads of Beetles, stocks, and handles of Tools (for all which purpofes its extream toughnefs commends it to the Hufbandman) being planted in fmall Foffes, or Trenches, at half a foot interval, and in the fingle row it makes the nobleft and the ftatelieft Hedges for long Walks in Gardens, or Parks, of any Tree whatfoever whofe leaves are deciduows, and forfake their branches in Winter; becaufe it grows tall, and fo fturdy'as not to be wronged by the Winds : Befides, it will furnifh to the very foot of the ftem, and flourifhes with a gloffie and polifh'd verdure which is excceding delightful, of long continuance, and of all other the harder Woods the fpeedieft Grower; maintaining a flender, upright ftem, which does not come to be bare, and flicky in many years. That admirable Efpalier-bedge in the long middle walk of Luxembourg Garden at Paris (then which there is nothing more graceful) is planted of this Tree; and fo is that Cradle or Closewalk, with that perplext Canopie, which covers the feat in his Miajefties Garden at Hampton-Court. Thefe Hedges are tonfile; but where they are maintain'd to fifteen or twenty foot height (which is 
very frequent in the places before mention'd) they are to be cut, and kept in order with a sythe of four foot long, and very little falcated; this is fix'd on a long fneed or ftreight handle, and does wonderfully expedite the trimming of thege and the like Hedges.

\section{CHAP. XIII. \\ Of the Lime-Tree.}

Limeotree.

1. THe Lime-Tree, [Tilia] is of two kinds; the Male, which is harder, fuller of knots, and of a redder colour; but producing neither Flower, nor Seed, as does the Female, whofe Bloffome is very odoriferous perfuming the Air : The Wood is likewife thicker, of fmall pith, and not obnoxious to the Worm. We fend commonly for this Tree into Flanders and Holland, to our exceffive coft, whiles our own Woods do in fome places fpontaneoully produce them, from whence I have received many of their Berries; fo as it is a thameful negligence, that we are no better provided of Nurferies of a Tree fo choice and univerfally acceptable. For fo they may be rais'd either of the Seeds in October; or (with better fuccefs) by the Suckers, and Plants, after the fame Method, and in as great abundance as the Elme, like to which it thould be cultivated.

2.The Lime-tree affects a rich feeding Soil; In fuch Ground their growth will be almoft incredible for fpeed and fpreading. They may be planted as big as ones Leg; their Heads topp'd at about fix foot bole; thus it will become (of all other) the moft proper and beautiful for Walks, as producing an upright Body, fmooth and even Bark, ample Leaf, fweet Bloßom, and a goodly ßracle at di3. ftance of eighteen or twenty foot. The Prince Elector did lately remove very great Lime-Trees out of one of his Forefts, to a ftcep hill exceedingly expos'd to the heat of the Sun at Hidelbourg; and that in the midft of summer: They grow behind that ftrong Topoer on the South-rseft, and moft torrid part of the eminence; being of a dry reddith barren earth; yet do they profper rarely well: But the heads were cut off, and the pits into which they were tranfplanted were(by the induftry and direction of one Monfiear de Son, a Frenchman) fill'd with a compofition of Eartb and cow-dung which was exceedingly beaten, and fo diluted with water as it became almoft a liquid pap: It was in this that he plunged the Roots, covering the furface with the turf: A fingular example of removing fo great Trees at fuch a feafon, and therefore by me taken notice of here exprelly.

4. The Timber of a well grown Lime is convenient for any ufe that the Willow isibut much to be preferr'd,as being both ftronger, and yet lighter; whence Virgil calls them tilias leves; and there- 
fore turn'd into Boxes for the Apothecaries; and Columella commends Arculas tiliaceas : with the Twigs they made Baskets, and Cradles; and of the fmoother fide of the bark Tablets for Writing ; for the antient Pbilyra is but our Tilia. The Gravers in wood do fometimes make ufe of this fine Material; and even of the courfeft membrane, or livers of the Tree growing 'twixt the bark and the main body, they now twift into Baß-ropes; Befides the Truncheons make a far better Coal for Gun-powder then that of Alder it felf : and the extraordinary candor and lightnes 3 bas dignifid it above all the Woods of our Forest in the hands of the Right Honourable, the White-ftave Officers of his Majesties Imperial Court. Thofe royal Plantations of thefe Trees in the Parks of Hampton-Court, and St. Fames's will fufficiently inftruct any man how thefe (and indeed all other Trees which ftand fingle) are to be govern'd, and defended from the injuries of Beafts, and fometimes more unreafonable Creatures, till they are able to protect themfelves. In Holland (where the very high-ways are adorn'd with them) they frequently clap three or four Deal-boards (in manner of a clofe trunk) about them; but it is not fo well; becaufe it keeps out the air which thould have free accels, and intercourfe to the bole, and by no means be excluded from flowing freely about them, or indeed any other Trees; provided they are fecur' $d$ from the violence of impetuous winds, $\mathscr{\sigma} c$. as his $M a-$ jefties are without thofe clofe Coffins, in which the Dutch-men feem rather to bury them alive : In the mean time, is there a more ravilhing, or delightful object then to behold fome intire ftreets, and whole Tomns planted with thefe Trees, in even lines before their doors, fo as they feem like Cities in a wood? this is extreamly frefh, and skreens the houfes both from Winds, sun and Duft; then which there can be nothing more defirable where ftreets are much frequented.

\section{CHAP. XIV.}

\section{of the Quick-Beam.}

I. THe 2uick-beam, [Ornus] or (as others term it) the Wbitchen, 2uick-beam. is a pecies of Wild-Aß乃. The Berries which it produces in odfober may then be fown; or rather the Sets planted : It rifes to a reafonable ftature, fhoots upright, and llender; and confifts of a fine fmooth bark. It delights to be both in Mountains and Woods, and to fix it felf in good light ground. Befides the ufe of it for the Husbandmans Tools (as once by a Statute of Hen. 8. for Bows) and for Fuel, I have not yet obferved any other; fave that the Blofjoms are of an agreeable fcent.

CHAP. 


\section{CHAP. XV.}

\section{of the Birch.}

Bircb. I. THe Birch [Betula] is altogether produc'd of fuckers (though it Theds a kind of samera about the spring) which being planted at four or five foot interval, in fmall twigs, will fuddenly rife to Trees; provided they affect the ground, which cannot well be too barren; for it will thrive both in the dry, and the wet, Sand and Stony, Marflues and Bogs; the water-galls, and soliginous parts of Forefts that hardly bear any grafs, do many times fpontaneoufly produce it in abundance whether the place be high, or low, and nothing comes amifs to it.

Plant the fmall $t w i g s_{3}$, of Juckers having roots, and after the firft year cut them within an inch of the furface; this will caufe them to ,prout in ftrong, and lufty $t u f t s$, fit for $\operatorname{cop} \int e_{2}$ and spring-woods; or, by reducing them to one ftem, render them in a very few ycars fit for the Turner. For though Birch be of all other the worlt of Timber; yet bas it its various ufes, as for the Husbandmans ox-yoaks; alfo for Hoops, Paniers, Brooms, Wands, Bavin and Fuel; great and fmall-coal, which latt is made by charking the nlenderent brufh, and fummities of the twigs; as of the tops and loppings M. Homards new Tanne: Laftly, of the wbiteft part of the old mood, found commonly indoating Birches, is made the grounds of our Gallants sweet-powder; to fay nothing here of the Magifterial Fafces, for which antiently the Cudgels were us'd by the Lictor; as now the gentler Rods by our tyrannical Pedagogues.

3. I hould bere add the ufes of the water too, had I not already protefted againft tampering with the Medicinal virtues of Trees, in the entrance of this Treatife : But if the fovereign effects of the jwice of this defpicable Tree fupply its other defects (which makes fome judge it unworthy to be brought into the Catalogue of Woods to be propagated) I may for once be permitted to play the Empiric, and to gratifie our laborious Wood-man with a draught of his own Liquor: And the rather, becaufe thefe kind of Secrets are not yet fufficiently cultivated; and ingenious Planters would by all means be encourag'd to make more trials of this nature, as the Indians, and other Nations have done on their Palmes, and Trees of feveral kinds, to their great emolument. The Myftery is no more then this: About the beginning of March (when the buds begin to be proud and turgid) with a Chizeland a Mallet cut a flit almoft as deep as the very pitb, under fome bough, or branch of a well fpreading Birch; cut it oblique and not long-2says (as a good Chirurgion would make his orifice in a Vein) inferring a fmall ftone or chip, to keep the lips of the wound a little open: Sir Hugb Plat, giving a general rule for the gathering of $\int a p$, and tapping of 7 rees, would have it done within one foot of the ground, the firft 


\section{$A$ Difcourfe of Forent-Tiees.}

rind taken off, and then the white bark flit over-twhart, no farther then to the body of the Tree: Moreover; that this wound be made only in that part of the barkwhich refpects the southsoest, or between thofe quarters; becaufe (fayshe) little, or no fap rifeth from the Northern.

In this $\int i t$, by the help of your knife to open it, he directs that a leaf of the tree be inferted, firft fitted to the dimenfions of the flit, from which the $\int a p$ will diftill in manner of flitration:take away the leaf, and the bark will clofe again, a little earth being clapped to the flit: Thus the Knight for any Tree: But we have already fhew'd how the Birch is to be treated: Faften therefore a Bottle or fome fuch convenient $V e f f e l$ appendant : this does the effect better then perforation or tapping: Out of this aperture will extil a limpid and clear water, retaining an obfure fmack both of the tafte and odor of the Tree; and which (as I am credibly inform'd) will in the fpace of twelve or fourteen days preponderate, and outweigh the whole Tree it felf, body and roots; which if it be conftant, and fo happen likewife in other Frees, is not only ftupendious, but an experiment worthy the confideration of our profoundeft Philofopbers: an ex fola aqua funt Arbores? whether water only be the principle of Vegetables, and confequently of Trees : For evident it is, that we know of no Tree which does more copioully attract, be it that fo much celebrated pirit of the World (as they call it) inform of water (as fome) or a certain Jpecifique liquor richly impregnated with this Balfamical property: That there is fuch a Magnes in this fimple Tree as does manifeftly draw to it felf fome occult, and wonderful virtue, is notorious; nor is conceivable, indeed, the difference between the efficacy of that liquor which diftills from the bole or parts of the Tree neerer to the Root, (where Sir Hugh would celebrate the Incifion) and that which weeps out from the more fublime Branches : But I refer thefe difquifitions to the learned; efpecially, as mention'd by that incomparable Philofopher, and my moft noble Friend, the honcurable Mr. Boyle, in his fecond part of the ufefulnefs of Natural PbiloSophy: SeCt. I. EfJay $3^{d}$. where he fpeaks of the Manna del Corpo, or Trunk-manna, as well as of that Liquor from the bough fo of the Sura which the Coco-trees afford ; and that Polonian fecret of the Liquor of the Wall-nut-tree root; with an encouragement of more frequent Experiments to educe saccharine fubftances upon thefe occafions : But the Book being publifh'd fo long fince this Difcourfe was ready, I have only here the liberty to refer the Reader to one of the beft Entertainments in the world.

4. In the mean time, the liquor of this Tree is efteem d moft powerful for the diflolving of the stone in the bladder : Helmont thews how to make a Beer of the water; but the Wine is a moft rich Cordial, curing (as I am told) Confumptions, and fuch interiour difeafes as accompany the stone in the Bladder or Reins : This Wine, exquifitely made, is fo frong, that the common fort of ftone-bottles cannot preferve rhe pirits, fo fubrilc they are and volatile; and yet it is gentle, and very harmlels in operation within the 
body, and exceedingly tharpens the Appetite, being drank ante paftum : I will prefent you a Receipt, as it was fent me by a fair Ladj;

To every gallon of Birch-mater put a quart of Hony well ftirr'd together; then boil it almoft an hour with a few cloves, and a little Linson-peel, kecping it well fcumm'd: When it is fufficiently boil'd, and become cold, add to it three or four fpoonfuls of good Ale to make it work (which it will do like new Ale) and when the reft begins to fettle, bottle it up as you do other winy liquors. It will in a competent time become a moft brifk and fpiritous Drink, which (befides the former virtues) is a very powerful opener, and doing wonders for cure of the Ptbifick: This Wine may (if you pleafe) be made as fuccersfully with sugar in ftead of Hony, tbj. to each Gallon of Water; or you may dulcifie it with Raifins, and compole a Raifin-mine of it. I know not whether the quantity of the fweet Ingredients might not be fomewhat reduc' $d$, and the operation improv'd : But I give it as receiv'd.

But befides thefe, Beech, Alder, Afo, Elder, Cuc. would be attempted for Liquors: Thus Crabs, and even our very Brambles may poftubly yield us medical and ufeful Wines. The Poplar was heretofore efteem'd more pbyfical then the Betula. The fap of the Oak, juice, or decoction of the inner bark cures the Fafsions, or Farcy, a virulent and dangerous infirmity in Horfes, and which (like Cancers) were reputed incurable by any other Topic, then fome actual, or potential cautery: But, what is more noble; a dear friend of mine affur'd me, that a Country Neigbbour of his (at leaft fourfcore years of age) who had lain fick of a bloody strangury (which by cruel torments reduc'd him to the very article of death) was, under God, recover'd to perfect, and almoft miraculous health, and ftrength (fo as to be able to fall ftoutly to his labour) by one fole draught of Beer, wherein was the decocfion of the internal bark of the oak-tree; And I have feen a compolition of an admirable fuderific, and diuretic for all affections of the Liver out of the like of the Elm, which might yet be drank daily as our Cophee is, and with no lefs delight; but 2 uacking is not my trade: 1 fpeak only here as a plain Husband-man, and a fimple Forefter, out of the limits whereof I hope I have not unpardonably tranf. grefs'd. Tan was a Phyfician, and be (you know) was Prefident of the Woods. But I proceed.

\section{CHAP. XVI.}

\section{of the Hafell.}

Hafel. I. THe Hafell is bett rais'd from the Nuts, which you thall fow like Maft in a pretty deep furrow toward the end of February: Light ground may immediately be fown and parrom ${ }^{\circ} d$ in very accurately; but in cafe the mould be clay, plow it earlier, 
and let it be fufficiently mellow'd with the frosts; and then the third year cut your Trees near to the ground with a fharp Bill, the Moon decreafing.

2. But if you would make a Grove for pleafure, plant them in Foffes at a yard diftance, and cut them within half a foot of the earth, drefling them for three or four springs, and Autumns, by only loofning the Mould a little about their roots. Others there are who fet the Nuts by hand at one foot diftance, to betranjplanted the third year at a yard afunder : But this work is not to be taken in hand fo foon as the Nuts fall, till Winter be well advanc'd; becaufe they are exceedingly obnoxious to the frofts; nor will they fprout till the spring: Befides, Vermine are great devourers of them: Preferve them therefore moift, not mouldy, by laying them in their own dry leaves, or in Sand, till January.

\section{Plant is or dure Coryli nafcuntur-...-.}

3. Hafels are likewife propagated of sets, and suckers; from whence they thrive very well, the floots being of the fcantlings of fmall wands, and fritches, or fomewhat bigger, and fuch as have drawn divers hairy twigs, which are by no means to be difbrancb'd, no more then their Roots, unless by a very fparing and difcreet hand. Thus your Coryletum or Copse of Hafels being planted about Autumn, may (as fome practife it) be cut within three or four inches of the ground the spring following, which the new Cion will fuddenly repair in clufters and tufts of fair poles of twenty, and fometimes thirty foot long: But, I rather thould fpare them till two, or three years after, when they thall have taken frong hold, and may be cut clofe to the very earth; the improfperous, and feeble ones efpecially. Thus are likewife Filberts to be treated, both of them improv'd much by tranfplanting.

4. For the place, they above all affect cold, barren, dry and fandy grounds; alfo Mountains, and even rockie foils produce them; but more plentifully if fomewhat moift, dankifh, and moffie, as in the frefher Bottoms, and fides of Hills, and in Hedge-rows. Such as are maintain'd for Copses, may after twelve years be fell'd the firft time; the next at feven or eight, \& $c$. for by this period their Roots will be compleatly vigorous. You may plant them from october to Fanuary, provided you kcep them carefully roeeded till they have taken faft hold.

5. The ufe of the Hafel is for Poles, Spars, Hoops, Hurdles, Forks, Angling-rods, Faggots, Coals; alfo for With's and bands, upon which I remember Pliny thinks it a pretty Speculation, that a wood fhould be ftronger to bind withall being bruis' $d$ and divided, then when xxbole and entire; laftly, for riding switcbes and Divinatory Rods for the detecting and finding out of Minerals; at leaft, if that tradition be no impofture.

There is a compendious expedient for the thickning of Copses which are too tranjparent, by laying of a sampler, or pole of an

$$
\mathrm{G}_{2} \text { Hafel? }
$$


Hafel, A $h$, Poplar, duc. of twenty, or thirty foot in length (the head a little lopp'd) into the ground, giving it a chop neer the foot, to make it fuccumb; this faftned to the earth with a bookor two, and cover'd with fome frefh movld at a competent depth (as Gard'nors lay their Carnations) will produce a world of fuckers, thicken and furnifh a Copse fpeedily. But I am now come to the Water-fide; let us next confider the Aquatic.

\section{CHAP. XVII.}

\section{Of the Poplar.}

Poplar. 1. T Begin this fecond claß (according to our foriner Diftribution) with the Poplar, of which there are feveral kinds; White, Black, Goc. befides the Aßpen: The wobite is the moft ordinary with us, to be raic'd in abundance by every fet or flip: Fence the ground as far as any old Poplar roots extend, they will furnilh you with fuckers innumerable, to be lip'd from their mothers, and tranplanted the very firft year. You thall need no other Nurfery. When they are young their leaves are fomewhat broader, and rounder then when they grow aged. In moit, and boggy places they will flourith wonderfully, fo the ground be not pewing; but efpecially neer the Margins and banks of Rivers,

$$
\text { Populus in fluviis - Virg. }
$$

Alfo trunchions of feven, or eight foot long, thruft two foot into the earth, when once rooted, may be cut at fix inches above ground; and thus placed at a yard diftant they will immediately furnifh a kind of Copfe. But in cafe you plant them of rootedtrees, or fmaller fets, fix them not fo deep; for though we bury the Trunclions thus profound; yet is the root which they frike

2. Afpen, commonly but fhallow. The Apen only (which is that kind of white Poplar bearing a fmaller, and more tremulous leaf) thrufts down a more fearching foot, and in this likewife differs, that be takes it ill to have his bead cut off: Pliny would have lhort trunchions couched two foot in the ground (but firft two days dry'd) at one foot and half diftance, and then moulded over.

3. Abele. 3. There is fomething a finer fort of white Poplar which the Dutch call Abele, and we have much tranfported out of Holland: Thefe are alfo beft propagated of fips from the Roots, the leaft of which will take, and may in March, at three, or four years growth be tranfplanted.

4. In Flanders (not in France, as a late Author pretends) they have large Nurferies of them, which firft they plant at one foot diftance, the mould light, and moift; but, as I faid, they muft be interr'd pretty deep, and kept clean by pruning them to the mid- 
dle floot for the firft two years, and fo till the third or fourth: When you Tranfplant, place them at eight, ten or twelve foot Interval: They will likewife grow of Layers, and even of cuttings: In three years they will come to an incredible altitude; in troelve, be as big as your middle; and in eighteen, or twenty, arrive to full perfection: A pecimen of this advance we have had of an Abele Tree at Sion, which being lopp'd in Febr. 1651. did by the end of odober 52. produce branches as big as a mans wrift, and Jeventeen foot in length: As they thus increale in bulk; their value and price advance likewife; fo as the Dutcblook upon a Plantation of thefe Trees as an ample portion for a Daugbter, and none of the leaft effects of their good Husbandry; which truly may very well be allow'd, if that calculation hold, which the Kright has aflerted, who began his Plantation not long fince about Richmond; that 30 li. being laid out in thefe Plants, would render at the leaft ten thoufandpounds in eighteen years : Every Tree affording thirty rlants, and every of them thirty more, after each feven years improving twelve pcnce in growth, till they arriv'd to their acme.

5. The Black Poplar grows rarely with us; it is a fronger, and taller'Tree then the White, the leaves more dark, and not fo am ple. Divers ftately ones of thefe I remember about the banks of Po in Italy, which River being the old Eridanus fo celebrated by the Poets in which the temerarious Pbreton is faid to have been precipitated, doubtlefs gave argument to that fiction of his fad Sifters Metamorphofis into thefe Trees; but for the Amber of their precious tears I could hear of no fuch matter, whiles paffing down that River towards Ferrara I diverted my felf with this ftory of the ingenious Foet.

6. The beft ufe of the Poplar, and Abele (which are all of them bopitable Trees, for any thing thrives under their ßades) is for Walks, and Avenues about Grounds which are fituated low, and neer the water, till coming to be very old they are apt to grow knurry, and out of proportion: The Timber is incomparable for all forts of white Woodden VefJels, as Trays, Bowls and other Turners ware; likewife to make Carts; becaufe it is exceeding light; for Vine, and Hop-props, and divers viminious works. The loppings in Fanuary are for the Fire; and of the trigs (with the leaves on) are made Brooms. The Brya or Catkins attract the Bees; as do alfo the leaves more tenacious of the Mel-dems then moft other Foreft-trees, the Oak excepted.

Of the Apen our Woodmen make Hoops, Fire-rood and coals, orc. 


\section{H A P. XVIII.}

\section{Of the Alder.}

Alder.

1. THe Alder is of all other the moft faithful lover of waparts, or water-galls of Forefts, cralsisg paludibus Alni. They are propagated of Trunchions, and will come of Seeds (for fo they raife them in Flanders, and make wonderful profit of the Plantations) like the Poplar; or of Roots, which I prefer, being fet as big as the fmall of one's leg, and in length about two foot; whereof one would be plunged in the mud. This profound fixing of Aquatic-trees being to preferve them fteedy, and from the concuftions of the minds, and violence of waters, in their liquid and flippery foundations. They may be placed at four, or five foot diftance; and when they have ftruck root, you may cut them, which will caufe them to fpring in clumps, and to fhoot out into many ufeful poles. But if you plant fmaller $\int_{e} t$, cut them not till they are arriv'd to fome competent bignefs; and that in a proper Jeafon; which is, for all the Aquatics, not till Winter be well advanc'd, in regard of their pithy fubftance. Therefore fuch as you thall have occafion to make ufe of before that period ought to be well grown, and fell'd with the earlieft, and in the firft quarter of the increafing Moon; that fo the fucceffive Shoot receive no prejudice.

2. There are a fort of Husbands who take exceffive pains in ftubbing up their Alders where-ever they meet them in the boggy places of their grounds, with the fame indignation as one would extirpate the moft pernicious of Weeds; and when they have finifh'd, know not how to convert their beft Lands to more profit then this (feeming defpicable) plant might lead them to, were it rightly underftood : befides, the fhadow of this Tree does feed and nourifh the very gra $\beta$ which grows under it.

3. You may cut Aquatic-trees every third, or fourth year, and fome more frequently, as I thall thew you hereafter. They thould alfo be abated within half a foot of the principal bead, to prevent the perilhing of the mainftock; and befides, to accelerate their fprouting. In fetting the Trunchions it were not amiss to prepare them a little after they are fitted to the fize, by laying them a while in water; this is alfo practicable in Willows, occ.

4. Of old they made Boats of the greater parts of this Tree

Tunc alnos primum fluvii fensêre cavatas.

Necnon \&u torrentem undam levis innatat aluzs

MijJa Pado- 2.

And as then, fo now, are over-grown Alders frequently fought after, for 
for fuch Buildings as lyecontinually under water, where it will harden like a very ftone; whereas being kept in any unconftant temper it rots immediately: Vitruvius tells us, that the Moraffes about Ravenna in Italy were pil'd with this Timber, to fuperftruct upon, and highly commends it.

5. The Poles of Alder are as ufeful as thofe of Willows; but the coals far exceed them; efpecially for Gun-powder: The Wood is likewife ufeful for Piles, Pumps, Water-pipes, Troughs, Sluces, Wooden-beels, and the fwelling buncbes which are now and then found in the old Trees, afford the Inlayer pieces curiounly cbanletted and very hard, \& c. but the Fagots better for the fire then for the draining of Grounds, by placing them (as the guife is) in the Trenches; which old rubbith of Flints, stones, and the like grofs materials, does infinitely exceed, becaufe it is for ever, preferves the Draines hollow, and being a little moulded over will produce good graßs, without any detriment to the yround; but this is a fecret, not yet well underfood, and would merit an exprefs Paragraph, were it here feafonable,

Jo jam nos inter opacas

Mufa vocat Salices -

\section{CHA P. XIX.}

Of the Witby, Sally, Ozier, and Willow.

I. CInce Cato has attributed the third place to the salicfum, pre- Witby.

$\checkmark$ ferring it even next to the very ortyard; and (what one would wonder at) before even the olive, Meadow, or Corn-field it felf (for Salictum tertio loco, nempe poft vineam, ouc.) and that we find it fo eafily rais'd, of fo great and univerfal $v \int e$, I have thought good to be the more particular in my Difcourfe upon them; efpecially, fince fo much of that which I fhall publifh concerning them, is deriv'd from the long experience of a moft learned and ingenious perfon, from whom I acknowledge to have receiv'd many of thefe hints.

Not to perplex the Reader with the various names, Greek, Gallic, Sabinic, Amerine, Vitex, \&uc. better diftinguifh'd by their growth, and barke; and by Latine Autbors all comprehended under that of salices, I begin with the Witby. The Withy is a reafonable large Tree, and fit to be planted on high banks; becaufe they extend their roots deeper then either sallyes or Willows. For this reafon you thall plant them at ten or twenty foot diftance; and though they grow the floweft of all the twiggy Trees; yet do they recompence it with the larger crop; the rood being tough, and the twigs fit to bind ftrongly; the very peelings of the branches being ufeful to bind Arbour-poling, and in Topiary works, Vineyards, EJpalier-fruit, and the like. 
2. There are two principal forts of thefe Witbies, the boary, and the red Witby which is the Greek; tougheft, and fitteft to bind whiles the twigs are flexible and tender.

S.llyes. I. Sallyes grow much fafter, if they are planted within reach of water, or in a very moorifh ground, or flat plain; and where the foil is, by reafon of extraordinary moifture, unfit for Arable, or Meadow; for in thefe cafes it is an extraordinary improvement: In a word, where Birch, and Alder will thrive.

2. Before you plant them, it is found beft to turn the ground with a spade; efpecially, if you defign them for a tlat.

3. We have three forts of sallys amongt us: The vulgar, which proves beft in dryer banks, and the bopping sallys which require a moifter foil, growing with incredible celerity: And a thirdkind, of a different colour from the other two, having the twigs reddifh, the leaf not fo long, and of a more dufky green; more brittle whilft it is growing in twigs, and more tough when arriv'd to a competent fize : All of them ufeful for the Thatcher.

4. Of the fe, the bopping sallys are in greateft efteem, being of a clearer terfe grain, and requiring a more fucculent foil ; beft planted a foot deep, and a foot and half above ground (though fome will allow but a foot) for then every branch will prove excellent for future fetlings. After three years growth (being cropp'd the fecond and third) the firft years increafe will be 'twixt eight and tmelve foot long generally; the fecond years growth frong enough to make Rakes and Pike-ftaves; and the third for M. Blitbes's trenching Plom, and other like Utenfils of the Hufbandman:

5. If ye plant them at full height (as fome do, at four years growth, fetting them five, or fix foot length, to avoid the biting of Cattel) they will be lefs ufeful for ftraight ftaves, and for fetlings, and make lefs fpeed in their growth; yet this alfo is a confiderable improvement.

6. Thefe would require to be planted at leaft five foot diftance (fome fet them as much more) and in the Quincunx order: If they affect the fail, the leaf will come large, half as broad as a mans hand, and of a more vivid green, always larger the firft sear, thenafterwards: fome plant them floping, and crofs-wife like a bedge; but this impedes their wonderful growth; and (though Pliny feems to commend it, teaching us how to excorticate fome places of each $\int e t$, for the fooner production of fhoots) it is but a deceitful Fence, neither fit to keep out Swine, nor Sheep; and being fet too neer, inclining to one another, they foon deftroy cach other.

7. The worft sallys may be planted fo neer yet, as to be inftead of ftakes in a bedge, and then their tops will fupply their dwarfihnefs; and to prevent Hedge-breakers many do thus plant them; becaufe they cannot eafily be pull'd up, after once they have fruck root.

8. If fome be permitted to wear their tops five or fix years, their 
their Palms will be very ample, and yield the firft, and moft plentiful relicf to Bees, even before our Abricots bloffom.

The bopping Sallys open, and yield their Palms befure other Sallys, and when they are blown (which is about the exit of May, or fometimes Fune) the Palms are four inches long, and full of a fine Cotton : A poor Body might in an hours fpace gather a pound or two of it, which refembling the fineft filk, might doubtlefs be converted to fome profitable ufe by an ingenious Howe-wifie.

9. Of thefe Hopping sallys, after three years rooting, each plant will yield about a fcore of $\int$ taves of full eight foot in length, and fo following, for ufe, as we noted above: Compute then how many fair Pike-ftaves, Perches, and other ufeful Materials, that will amount to in an Acre, if planted at five foot interval: But a fat, and moift foil requires indeed more fpace then a lean or dryer; namely $\int 2 x$ or eight foot diftance.

10. You inay plant fetlings of the very firft years growth; but the fecond year they are better, and the third year better then the fecond; and the fourth as good as the third; efpecially, if they approach the water. A bank at a foot diftance from the water is kinder for them then a Bog, or to be altogether immers'd in the water.

I1. "Tis good to new-mould them about the Roots every fecond or third year; but Men feldom take the pains. It feems that Sallys are more hardy then even Willows and oziers, of which Colunella takes as much care as of Vines themfelves. But 'is cheaper to fupply the vacuity of fuch accidental decays by a new plantation, then to be at the charge of digging about them three times a year, as that Author advifes; feeing fome of them will decay, whatever care be ufed.

12. Sallys may alfo be propagated like Vines, by courbing, and bowing them in Arcbes, and covering fome of their parts with mould, duc.

13. For fetlings, thofe are to be prefert'd which grow neereft to the ftock, and fo (confequently) thofe worf which moft approach the top. They thould be planted in the firft fair, and pleafant weather in February, before they begin to bud. They may be cut in spring for Fuel; but beft in Autumn for ufe; but in this work (as of Poplar) leave a twig or two; which being twifted Arch-mife will produce plentiful jprouts, and fuddenly furnifh a bead.

14. If in our Copes one in four were a sally fet, amongft the reft of varieties, the profit would recompence the care.

15. The fwift growing Sally is not fo tough, and hardy for fome ufes as the flower, which makes ftocks for Gard'ners spades; but the other are proper for Rakes, Pikes, Mops, \&c. Sally-coal is the fooneft confum'd; but of all others the moft accommodate fo: Painters to defign their Work, and firft draught on paper with, \&uc. as being fine, and apt to lit into Pencils.

16. To conclude, there is a way of graffing a sally trunchion; 
take it of two fo ot and half long as big as your wrift; Graff at both ends a Figue, and Mulberry Cion of a foot long, and fo (without claying) fet the ftock fo far into the ground as the plant may be three or four inches above the earth: This will thrive exceedingly the firft year, and in three be fit to tranjplant. The feafon for this curiofity is Fcbruary.

Oziers. I. Oziers are commonly diftinguifh'd from sallyes, as salleys are from Withies; being fo much fmaller then the sallyes, and fhorter liv' $d$, and requiring more conftant moifture, and yielding more limber, and flexible twigs for Baskets, Flaskets, Hampers, Chairs, Hurdles, stages, Bands, $J_{u}$. likewife for filh Wairs, and to fupport the Banks of impetuous Rivers: In fine, for all Wicker and Twiggy Works:

\section{Viminibus salices}

2. But thefe fort of Oziers would be cut in the new floot; for if they ftand longer they become more inflexible; cut them clofe to the bead (a foot or fo above earth) about the beginning of ocfober; unlefs you will attend till the cold be pat, which is better; and in the decreafe, for the benefit of the Workman; though not altogether for that of the ftock, and fucceeding froot: When they are cut, make them up into bundles, and give them Ahelter; but fuch as are for White-2sork. (as they call it) being thus faggotted, Thould be fet in water, the ends dipped; but for black, and unpeel'd, preferv'd under covert only: The peelings of the former are for the ufe of the Gard'ner.

3. We have in England thefe three vulgar forts; one of little worth, being brittle, and very much refembling the fore-mention'd sally, with reddifh twigs, and more greenifh, and rounder leaves: Anotber kind rhere is, call'd Perch, of limber and green twigs, having a very flender leaf; the third fort is totally like the fecond, only the twigs are not altogether fo green, but yellowiflo, and neer the Popinjay: This is the very best for $v \int e$, tough and hardy.

4. Thefe choicer forts of oziers, which are ever the fmallest; alfo the golden-yellow and white which is preferr ${ }^{\circ} \mathrm{d}$ for propagation and to breed of, Thould be planted of fips of two, or three years growth, a foot deep, and half a yard length, in Moorifh ground, or Banks, or elfe in Furrows; fo as the roots may frequently reach the water; for Fluminibus salices — and at three, or four foot diftance.

5. The feafon for planting is in mid-February; but Cattel being exceffively licorith of their leaves and tender buds, fome talk of a graffing them out of reach upon sallys, and by this to advance their fprouting; but as the poork would confume time, fo have I never feen it fucceed.

6. Some do alfo plant Oziers in their Ėiglsts like Quick-fets, thick, and (neer the water) keep them not more then half a foot above ground; but then they muft be diligently cleans'd fronı 
'Moß, slab and $O u z e$, and frequently prun'd (efpecially the fmaller fpires) to form fingle thoots; at leaft, that few, or none grow double : Thefe they bead every fecond year about september, the Autumnal cuttings being beft for ufe : But generally

7. You may cut Withies, sallys, and Willows at any mild and gentle feafon between leaf and leaf even in Winter; but the moft congruous time both to plant and to cut them is Crefcente Lun $\hat{a}$ Vere, circa calendis Martias; that is, about the new Moon, and firft open weather of the early spring.

8. It is in France, upon the Loire, where thefe Eights (as we call them) and Plantations of oziers and Withies are perfectly underftood; as it feems in fome places alfo of our own Country, where I have heard twenty pounds has been given for one Acre. To omit nothing of the culture of this ufeful Ozier, Pliny would have the place to be prepar'd by trenching it a foot and half deep, and in that to fix the fets or cuttings of the fame length at fix foot interval. Thefe (if the fets be large) will come immediately to be Trees; which after the firft three years are to be abated within two foot of the ground. Then, in April, he advifes to dig about them: Of thefe they formerly made Vine-props, and one Acre hath been known to yield props fufficient to ferve a Vineyard of twenty five Acres.

10. Fobn Tradefcan brought a fmall ozier from St. omers in Flanders, which makes incomparable Net-works, not much inferiour to the Indian twig or Bent-works which we have feen; but if we had them in greater abundance, we fhould haply want the Artificers who could imploy them.

I. Our common Willow of the moodier fort delights in Meads Willww. and Ditch-fides, rather $d r y$, then over wet (for fo they laft longeft) and would be planted of ftakes as big as on's leg, cut at the length of five or fix foot, and fix'd a foot or more into the earth; the bole made with an Oaken-ft ake and beetle, or with an Iron-crom (fome ufe a long Augur) fo as not to be forced in with too great violence: But firft, the Truncbions fhould be a little flop'd at both extreams, and the biggeft planted downwards: To this, if they are foak'd in water two or three days (after they have been fiz'd for length, and the twigs cut off ere you plant them) it will be the better. Let this be done in February. Arms of four years growth will yicld fubftantial fets to be planted at eight or ten foot diftance; and for the firft three years well defended from the $C a t$ $t e l$, who infinitely delight in their leaves, green or wither'd. Thus a Willow may continue tmenty, or five and twenty years, with good profit to the induftrious Planter, being beaded every four or five years, fome have been known to fhoot no lefs then twelve foot in one year, after which the old, rotten Dotards may be fell'd, and eafily fupplied. But if you have ground fit for whole Copjes of thiswood, cait it into double dikes, making every fo $\beta$ neer three foot wide; two and half in depth; then leaving four foot at leaft of ground for the earth (becaufe in fuch Plant ations the moifture fhould be below the roots, that they may rather fee, then feel the 
water) and two Tables of Sets on each fide, plant the Ridges of thefe Banks with but one fingle Table, longer and bigger then the Collatcral, viz. three, four, five or fix foothigh, and diftant from 3. each other about two yards. Thefe Banks being carefully kept meeded for the firft two years, till the Plants have vanquilid the Graß; every Acre at eleven, or twelve years growth, may yield you neer an bundred load of rood: Cut them in the spring for drefling; but in the Fall for Timber and Fuel: I have been inform'd, that a Gentleman in EJjex has lopp'd no lefs then 2000 yearly, all of his own planting.

4. There is a fort of Willow of a llender and longleaf, refem-

- bling the fmaller ozier; but rifing to a Tree as big as the Sally; full of knots, and of a very brittle fpray, only here rebears'd to acknowledge the variety.

5. There is likewife the Garden-millow, which produces a fweet and beautiful flower, fit to be admitted into our Hortulan ornaments, and may be fet for partitions of Squares; but they have no affinity with other. There is alfo in stropflire another very odoriferous kind.

6.What moft of the former enumerated kinds differ from the $\mathrm{Sal}$ lys, is indeed not much confiderable, they being generally ufeful for the fame purpofes; as Boxes, fuch as Apothecaries and Goldjnitbs ufe; for Cart-Saddle-trees, Harrows, shooe-makers Lafts, Heels, Clogs for Pattens, Pearches, Hop-poles; Ricing of kidny-beans, and for Supporters to Vines, when our Englifo Vineyards come more in requeft: Alfo for Hurdles, Sieves, Lattices; for the Turner, Coals and Bavin. The mood being preferv'd dry will dure a very long time; but that which is found wholly putrifi' $d$, and reduc'd to a loamy earth in the hollow trunks of Juperannuated Trees, is, of all other, the fitteft to be mingl'd with fine mould for the raifing our choicen Flowers, fuch as Anemonics, Ranunculuss's, Auriculas, and the like; for

Quid majora fequar? Salices, bumilesǵ, genift a

Aut illipecori fronden, aut pastoribus umbram

sufficiunt, Sepeniǵ Jatis, \& pabula melli.

\section{Georg. 2.}

7. Now by all thefe Plantations of the Aquatic Trees, it is evident the Lords of Moorith Common's, and unprofitable Wastes, may learn fome improvement, and the neighbour Bees be gratifi'd; and many Tools of Husbandry become much cheaper. I conclude, with the learned Stcphanus's note upon thefe kind of Trees, after he has enumerated the univerfal benefit of the Salictum : Nulliws enim tutior reditws, minorifve impendii, aut tempeftatis fecurior. 


\section{CHAP. XX. \\ Of Fences, Quicksets, \&c.}

I. Ur main Plantation is now finifh'd, and our Foreft adorn'd Fences. with a juft variety : But what is yet all this labour,but lofs of time, and irreparable expence, unlefs our young, and (as yet) tender Plants be fufficiently guarded from all external injuries? for, as old Tiufer,

\section{If Cattel, of Conn map enter to crop, kaung $\Phi^{2}$ ak is in Danger of loling bis top.}

But with fomething a more polifh'd ftile, though to the fame purpole, the beft of Poets,

\section{Texende fepes etiam, \& pecus omne tenendum est :

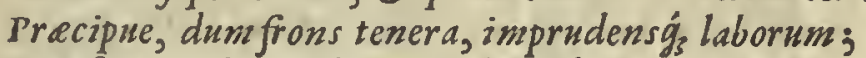 \\ Cui, Juper indignas byemes, folem ǵ, potentem, sylveftres Viri alfidue, caprexǵg ${ }_{3}$ equaces \\ Illudunt : Pafcuntur Oves, avidág juvence. \\ Frigora nec tantum cana concreta pruina, Aut gravis incumbens fcopulis arentibus estas 2 untum illi nocuere greges, duriǵ, venenum Dentis, or admorfa fignata in firpe cicatrix.}

\section{Georg. I.}

2. For the reafon that fo many complain of the improfperous condition of their Wood-lands, and Plantations of this kind, proceeds from this neglect; though (sbeep excepted) there is no imployment whatfoever incident to the Farmer, which requires lefs expence to gratifie their expectations: One diligent, and skilful Man will govern five bundred Acres : But if throwgh any accident a Beast thall break into his Mafters field; or the wicked Hunters make a gap for his dogs and borfes, what a clamor is there made for the difturbance of a years crop at moft in a little Corn? whiles abandoning his young Woods all this time, and perhaps many years, to the venomous bitings and treading of $\mathrm{Cattel}_{\text {, and other }}$ like injuries (for want of due care) the detriment is many times irreparable: Young Trees once cropp'd hardly ever recovering : It is the bane of all our moft hopeful Timber. But fhall I provoke you by an inftance? A Kins-man of mine has a Wood of more then 60 years ftanding; it was, before he purchas'd it, expos'd and abandon'd to the Cattel for divers years: fome of the outward fkirts were nothing fave forubs and miferable ftarvlings; yet fill the place had a difpofition to grow woody; but by this neglect contimually fupprefs'd. The induftrious Gentleman has Fenced in fome Acres of this, and cut all clofe to the ground; it is come in eight or nine years to be better worth then the mood of fixty; 


\section{A Difconne of Foren-Trees.}

and will (in time) prove moft incomparable Timber, whiles the other part fo many years advanc'd, fhall never recover; and all this from no other caufe, then preferving it fenc'd: Judge then by this, how our Woods come to be fo decried: Are five hundred sbeep worthy the care of a shepherd? and are not froe thougased Oaks worth the Fencing, and the infpection of a Haymard?

\section{Et dubitant homines ferere, at $\dot{g}_{s}$ impendere curam?}

Let us therefore (hut up what we have thus laborioully planted, with fome good 2 uick-Jet bedge.

2uick-fts. 1. The White-thorne which is the beft for Fencing, is either rais'd of seeds or Plants; but then it muft not be with depair, becaufe fometimes you do not fee them peep the firft year; for the Haw, and many other feeds, being invefted with a very hard Integument, will now and then fuffer imprifonment two.whole years under the earth; and impatience of this does often frufrate the expectation of the refurrection of divers feeds of this nature; fo as we frequently dig up, and difurb the beds. where they have been fown, in depair, before they have gone their full time; which is allo the reafon of a very popular miftake in other 2. Seeds: efpecially, that of the Holly, concerning which there goes a tradition, that they will not fprout till they be pafs'd throigh the Maw of a Thrugh; whence the faying, Turdus exitium funm cacat (alluding to the Vifcus made thereof, not the Misleto of Oak) but this is an errour, as I am able to teftifie on experience; they come up very well of the Berries, and patience; for (as I affirm'd) they will feep fometimes two entire years in their Graves; as will alfo the feeds of $x_{e m}$, sloes, Pbylerea'anguftifolia, and fundry otbers, whofe foclls are very bard about the fimall kernels; but which is wonderfully facilitated, by being (as we directed) prepar'd in beds, and magazines of earth or fand for a competent time, and then committed to the ground before the full in March, by which feafon they will be chitting, and fpeedily take root : Others bury them deep in the ground all Winter, and fow them in February: And thus I have been told of a Gentleman who has confiderably improv'd his Revenue, by fowing Haws only, and raifing Nurferies of 2uick-fets, which he fells by the lundred far and neer : This is a commendable induftry; any neglected corners of ground will

3. fit this Plantation: But Columella has another expedient fo: the raifing of our fpinetum, by rubbing the now mature Hips and Haws into the crevices of baß-ropes, and then burying them in a trench: whether way you attempt it, they muft (fo foon as they peep, and as long as they require it) be feduloully cieans'd of the meeds; which, if in beds for tranjplantation, had need be at the leaft three or four year; by which time, even- your feedlings will be of ftature fit to remove; for I do by no means approve of the vulgar premature planting of fets, as is generally us'd throughout England; which is to take fuch only as are the very $\int$ malleft, and fo to crowd them into three or fourfiles, which are both egregious mistakes.

4. Where- 
4. Whereas it is found by conftant experience, that plants as big as ones thumb, fet in the pofture, and at the diftance which we fpake of in the Horn-beam; that is, almoft perpendicular, and fingle, or at moft not exceeding a double row, do profper infinitely, and much out-ftrip the denfert, and clofeft ranges of our trifling Sets, which make but weak froots, and whofe roots do but hinder each other, and for being couch'd in that pofture on the fides of Banks and Fences (efpecially where the earth is not very tenacious) are bared of the mould which fhould entertain them, by that time the Rains and storms of one Winter have paffed over them. In Holland, and Flanders (where they have the goodlieft Hedges of this kind.about the Counter-fcarps of their invincible Fortifications, to the great fecurity of their Musketiers upon occafion) they plant them according to my defcription, and raife Fences fo fpeedily, and fo impenetrable, that our best are not to enter into the comparifon.

6. Your Hedge being yet young, thould be conftantly roeeded, though fome admit not of this work after Michaelmas, for Reafons that I approve not: It has been the practice of Herefordisire, in the plantation of 2uick-et-hedges, to plant a Crab-ftock at every twenty foot diftance; and this they obferve fo Rcligioufly, as if they had been under fome rigorous Statute requiring it : But by this means they were provided in a fhort time with all advantages for the graffing of Fruit amongt them, which does highly recompenfe their induftry.

7. When your Hedge is now about of fix years ftature, plaflo it about February or october; but this is the work of a very dextrous and skilful Husbandman; and for which our honeft Country-man M.Markam gives excellent directions; only I approve not fo well of his deep cutting, if it be poflible to bend it, having fuffered in fome thing of that kind: It is almoft incredible to what perfection fome have laid thefe Hedges, by the rural way of plafling, better then by clipping; yet may both be ufed for ornament, as where they are planted about our Garden-fences, and fields neer the Manfion. In Scotland by tying the young fooots with bands of bay, they make the ftems grow fo very clofe together, as that it enclofeth Rabbets in Warrens inftead of pales.

8. And now fince I did mention it, and that moft I find do greatly affect the ordinary way of 2uicking ( that this our Difcourfe be in nothing deficient) we will in brief give it you much after Geo. Markams defcription, becaufe it is the beft and moft accurate.

In a Ground which is more dry then wet (for watry places it abhors) plant your 2uick thus: Let the firft row of sets be placed in a trench of about half a foot deep, even with the top of your ditch, in fomewhat a lloping, or inclining pofture : Then having rais'd your bank neer a foot upon them, plant another rom, fo as their tops may juft peep out over the middle of the paces of your first row: Thefe cover'd again to the height or thicknefs of the other, place a third rank oppofite to the first, and then finith 
your bank to its intended height. The diftances of the plants would not be above one foot; and the feafon to do the work in niay be from the entry of February till the end of March; or elfe in September, to the beginning of December.

When this is finifh'd, you mult guard both the top of your Bank and outmoft verge of your Ditch with a fufficient $d r y$-bedge, interwoven from ftake to fake into the earth (which commonly they do on the bank) to fecure your 2uick from the fpoil of Cattle. And then being careful to repair fuch as decay, or do not fpring, by fuppling the dead, and trimming the reft; you thall after three years growth fprinkle fome Timber-trees amongft them; fuch as Oak, Beech, Afh, Maple, Fruit, or the like; which being drawn young out of your Nurferies, may be very eafily inferted.

But that which we affirm'd to rcquire the greateft dexterity in this work, is the artificial plafling of our Hedge when it is now arriv'd to a fix or feven years head.

In February therefore, or Ocfober, with a very tharp Bill cut away all fuperfluous $\beta$ rays and ftraglers which may hinder your progrefs, and are ufelefs. Then fearching out the principal ftems, with a keen and light Hatchet cut them lant-mife about three quarters through, and fo lay it from you Jloping as you go, folding in the leffer branches which fpring from them; and ever within a five, or fix foot diftance, where you find an upright fet (cutting off only the top to the height of your intended bedge) let it ftand as a t take to fortifie your work, and to receive the twinings of thofe branches about it. Laftly, at the top (which would be about five foot above ground) take the longeft, moft flender and flexible twigs which you referved (and being cut as the former where need requires) bind in the extremities of all the reft, and thus your work is finifh'd: This being done very clofe, and thick, makes an impregnable Hedge, in few years; for it may be repeated as you fee occafion; and what you fo cut away will help to make your dry-bedges for your young Plantations, or be profitable for the oven, and make good Bavin.

9. The Pyracanth, Paliurws, and like pretiofer forts of Thornc might eafily be propagated into plenty fufficient to ftore even thefe vulgar $V \int e s$ were Men induftrious; and then how beautiful, and fweet would the environs of our Fields be? for there are none of the pinouss farubs more hardy, nor fitter for our defence. Thus might Berberies now and then be alfo inferted among our bedges, which with the Hips, Haws, and Cornel-berries, do well in light lands, and would rather be planted to the South then North, or West, as ufually we obferve them.

10. Some mingle their very hedges with Oaklings, Afr, and Fruittrees fown, or planted, and 'tis a laudable improvement.

I1. In Cornwall they fecure their Lands and Woods with high Mounds, and on them they plant Acorns whofe roots bind in the loofer mould, and fo form a double, and moft durable Fence, incircling the Fields with a Coronet of Trees. They do likewife 
(and that with great commendation) make hedges of our Genista spinofa, prickly Furzes, of which they have a taller fort, fuch as Furzes. the French imploy for the fame purpofe in Britaign, where they are incomparable busbands.

13. It is to be fown (which is beft) or planted of the roots in a furrow : If fown, meeded till it be ftrong: both Tonfle, and to be diligently clip' $d$, which will render it very thick, an excellent and beautiful bedge: Otherwife permitted to grow at large, 'twill yield very good $F$ agot.

14. Thus, in fome places, they fow in barren grounds (when they lay them down) the laft crop with this feed, and fo let them remain till they break them up again, and during that interim, reap confiderable advantage: Would you believe (writes a worthy Correppondent of mine) that in Herefordpire (famous for. plenty of wood) their Thickets of Furzes (viz. the vulgar) hould yield them more profit, then a like quantity of the beft wheat land of England? for fuch is theirs; and in Devonfhire (the feat of the beft Husbands in the World.) they fow on their wort Land (well plow'd) the $\int e e d s$ of the rankeft Furzes, which in four or five years becomes a rich $W o o d$ : No provender makes horfes fo hardy, as the young tops of thefe Furzes; no other Wood fo thick, nor more excellent $\mathrm{FuCl}$; and for fome purpofes alfo, yielding them a kind of Timaber to their more humble buildings; and a great refuge for Fowl and other Game: I am affur'd, in Britaign'tis fometimes fown no lefs then twelve yards thick, for a fpeedy, profitable, and impenetrable Mound: If we imitated this busbandry in the barren places of Surrey, and other parts of this Nation, we might exceedingly fpare our moods; and I have bought the beft fort of French feed at the fhops in London.

15. This puts me in mind of the Broom; another improventent Broom. for Barren grounds, and faver of morefubftantial Fuel: It may be fown Englifh, or (what is more fweet; and beautiful) the Spanifh, with equal fuccefs:

16. In the Weftern parts of France, and Cornwall, it grows with us, to an incredible height (however our Poet give it the epithete of bumilis) and fo it feems they had it of old, as appears by Gratius his Genifte Altinates, with which (as he affirms) they us'd to make ftaves for their spears, and hunting Darts.

17. Laftly, a confiderable Fence may be made of the Elder, Elder, fet of reafonable lufty trunchions; much like the Willow, and (as I have feen them maintain'd) laid with great curiofity, and far ex-. celling thofe extravagant plantations of them about London, where the lops are permitted to grow without due and fkilful laying.

18. There is a fort of Elder which has hardly any Pith; this makes exceeding ftout Fences, and the Timber very ufeful for Cogs of Mills, and fuch tough employments.

19. The American rucca is a barder plant then we take it to be; for it will fuffer our tharpeft Winter, as I have feen by experience, without that trouble, and care of fetting it in Cafes in our Confervatories for byemation; fuch as have beheld it in Flower (which is. not indeed till it be of fome age) muft needs admire the beauty. 
of it; and it being eafily multiplied, why fhould it not make one of the beft and moft ornamental Fences in the world for our Gardens, with its natural palifados, as well as the more tender, and impatient of moifture the Aloes does for their Vineyards in Languedoc, \&c. but We believe nothing improvable, fave what our Grand-fatbers taught us.

And thus, having accomplinh'd what (by your commands) I had to offer concerning the propagation of the more Solid, Materi$a l$, and ufeful Trees, as well the Dry, as Aquatical; and to the beft of my talent fenc'd our Plantation in, I thould here conclude, and fet a Bound likewife to my Difconree, by making an Apologie for the many errours and impertinencies of it; did not the zeal, and ambition of this IlluStrious Society to promote and improve all Attempt's which may concern the rublick utility or Ornamint, perfwade $M e$, that what I am adding for the farther encouragement to the planting of fome other ufeful (though lefs Vulgar) Trees, will at leaft obtain your pardon, if it mifs of your Approbation.

Fruit-Trees. I. To difcourfe in this ftile of all fuch rruit-trees as would prove of greateft emolument to the whole Nation, were to defign a juft Volume; and there are directions already fo many, and fo accurately deliver'd and publifh'd (but which cannot be affirm'd of any of the former Clajfes of Foreft-trees and other remarkes, at the leaft to my poor knowledge and refearch) that it would be needlefs to Repeat.

2. I do only with (upon the profpect, and meditation of the univerfal Benefit) that every perfon whatfoever, worth ten pounds per annum, within his Majefties Dominions, were by fome indifpenfable statute oblig'd to plant his Hedge-rows with the beft and moft ufeful kinds of them; efpecially, in fuch places of the Nation, as being the more in-land Counties, and remote from the Seas and Navigable Rivers, might the better be excus'd from the planting of Timber, to the proportion of thofe who are more bappily and commodioufly fituated for the tranportation of it.

3. Undoubtedly, if this courfe were taken effectually, a very confiderable part both of the Meat and Drink which is fpent to our prejudice might be faved by the Countrey-people, even out of the Hedges and Mounds, which would afford them not only the pleafure and profit of their delicious Fruit, but. fuch abundance of Cider and Perry as thould fuffice them to drink of one of the moft wholefom and excellent Beverages in the World. Old Gerard did long fince alledg us an example worthy to be purfu'd; I bave feen (faith he, fpeaking of Apple-Trees, lib.3. cap.101.) in the Paftures and Hedgrows about the Grounds of a Worhipfinl Gentleman dwelling two miles from Hereford, called $M^{r}$ Roger Bodnome, fo many Trees of all forts that the Servants drink for the nooft part no other drink but that which is made of Apples: The quant ity is fuch, that by the report of the Gentleman bimself the Parfon bath for Tythe many Hog gheads of Cider: The Hogs are fed with the fallings of them, which are fo many that they make choice of thofe Apples they do cat, who will not tafte of any but of the beft. An Example doubtlefs to be 
followed of Gentlemen that have Land and Living; but Envy faith, The Poor will break down our Hedges, and wpe Sall bave the leaft part of the Fruit; but forwoard in the Name of God, Graff, Set, Plant, and nourifh up Trees in every corner of your Ground; the labour is fmall, the coft is nothing, the commodity is great; your felves frall bave plenty, the poor flall have fomembat in time of want to relieve their necelfity, and God Ball reward your good minds and diligence. Thus far honeft Gerard. And in truth with how fmall a charge and infinite pleafure this were to be effected, every one that is Patron of a little Nurfery can eafily calculate: But by this Expedient, many thoufands of Acres, fow'd now yearly with Barley, might be cultivated for Wheat, or converted into Pafture to the increafe of Corn, and Cattel: Befides the Timber which the Pear-tree affords, comparable (for divers curious $v \int_{e s}$ ) with any we have enumerated. But of this I am to render a more ample Accompt in the Appendix to this Difcourfe.

4. I would farther recommend the more frequent planting and propagation of Fir, Pine-trees and fome other beneficial Materials both for ornament and profit; efpecially, fince we find by experience, they thrive fo well, where they are cultivated for curiofity only.

\section{H.A P. XXI.}

Of the Fir, Pine, Pinater, Pitch-tree, otc.

1. THey are all of them eafily rais'd of the Kernels, and Nuts, 1 which may be gotten out of their cones and clogs, by expofing them a little before the fire till they begin to gape, and are ready to deliver themfelves of their burthen.

2. There are of the Fir two principal $\beta$ pecies; the Male which is the bigger Tree, and of a harder wood; the Female, which is much the fofter, and whiter. They may be fown in beds, or cafes, at any time during March; and when they peep, carefully defended with Furzes, or the like fence from the rapacious Birds, which are very apt to pull them up, by taking hold of that little infecund part of the feed which they commonly bear upon their tops: The Beds wherein you fow them had need be fhelter'd from the Southern Apects with fome skreen of Reed, or thick bedge : Sow them in thallow rills, not above half-inchdeep, and cover them with fine light mould: Being rifen a finger in height, eftablinh their weak ftalks, by fiefting fome more earth about them; efpecially the Pines, which being more topbeavy are more apt to fwag. When they are of two, or three years growth, you may translant them where you pleafe; and when they have gotten good root they will make prodigious Thoots; but not for the three or four firft years comparatively. 
3. The Pine is likewife of boh sexes, whereof the Male growing lower, hath its mood more linotty and rude then the Female. They would be gather'd in fine before they gape, and cultivated like the Fir in moft répects; only, you may bury the Hïlls al little deeper. By a friend of mine they were rolled in a fine compost made of sheeps-dung, and fcatter'd in Febrivary, and this way never fail'd; Fir and Pinie; they canne to be above Inich high by $M a y$ : this were an expeditious proceß for great Plantat iöbis:- unlefs you would rather fet the Pine as they do Peafe; but at wider diftances, that when there is occafion of removal, they might be taken ui with earth and all; becaufe they are (of all other Trees) the moft obrioxious to mifcarry without this caution; and therefore it were much better (where the Nuts might be commodiounly fet, änd defended) never to remove them at all, it gives this Tree fo confidérable á check.

4. I am affur'd (by a perfon moft worthy of credit) that in the Territory of Alzey (a Country in Germany, where they were miferably difteffed for Wood, which they had fo deftroy'd as that they were reduced to make ufe of stram for their beft Fuel) a very large Trad 'being newly plowed, but the Wars furprizing them, not fuffer'd to fow; there fprung up the next year a whole Foreft of Pine-trees, of which fort of Wood there was none at all within lefs then fourfcore miles; fo as 'tis verily conjectur'd by fome, they might be wafted thither from the Country of Weftrafra, which is the neereft part to that where they grow : If this be true, we are no more to wonder, how, when our oak-rooods are grubb'd up, Beech and Trees of otber kinds. have frequently fücceeded them : What fome impetuous Winds have done in this nature I could produce inftances almoft miraculous: I thall fay nothing of the opinion of our Mafter Varro, and the learned Theophrastus, who were both of a faith that the feeds of rlants drop'd out of the Air : Pliny in his 16. Book; Chap. 33 . upon difcourfe of the Cretan $C_{y j p r e} \beta_{\text {, }}$ attributes much to the indoles and nature of the foil, virtue of the climate; and tiisteffions of the Air : And indeed it is very ftrange what is affirm of that Pitcliy-rain, reported to have falleni about cyrevie, the year 430 . U. C. after which, in a flioit time fpring up a whole wood of the Trèes of Laferpitiumz, producing a precious Guin not much inferiour to Benzoin, if at leaft the ftory be warrantble: But of thefe Aerial irradiations, various conceptions and equivocal productions without $\int e e d, d c$. upon another occafion; if life and leifure permit me to finith what has been long under the hand, and file to gratifie our Horticultores: This prefent Treatife being but an imperfect limb of that more ample work.

5. In tranlplanting of the fe Refnaceous, and Conifeross Trees, you mutt never diminifh their beads, nor be at all bufie with their roots, which pierce deep, and is all their foundation, unlefs you find any of them bruifed, or much broken: Neither may you disbranch them, butwith great caution, as about March or before, or elfe in septewiber, when I advife you to sub over their 
wounds with a mixture of Cow-dung; the neglect of tbis coft me dear, fo apt are they to. fpend their $G u m$.

6. Some advife us to break the fhells of Pines to faeilitate their delivery, and I have eflay'd it; but to my lofs; Nature does obftetricate; and do that office of her felf when it is the beft feafon; neither does this preparation at all prevent thofe which are fo buried, whiles their hard Int eguments protect them both from rotting, and the Vermine.

7. The domeftic Pine grows very well with us; but the Pina-Pinafter. fter or wilder beft for Walks, becaufe it grows tall, and proud, maintaining their branches at the fides, which the Pine does lefs frequently.

8. The Fir grows talleft being planted reafonable clofe toget ther; but fuffers nothing to tbrive under them. The Pine not fo Inhopitable; for (by Plinies good leave) it may be fown with any Tree; all things growing well under its frade, and excellent in Woods, hence Claudian,

\section{Et comitem quercum Pinus amica trabit.}

9. They both affect the cold, bigh and rockie grounds's yet will grow in better; but not in over rich, and pinguid. The worft land in Wales bears (as I am told) large Pine; and the Fir according to his afpiring nature, loves alfo the Mountain more then the Vulley; though they will allo defcend, and fucceed very well in either; being defirous of plentiful waterings till they arrive to fome competent $\int t a t i r e ;$ and therefore they do not profper fo well in an over fandy, and bungry foil, or gravel, as in the very entrails of the Rocks, which afford more drink to the Roots, that penetrate into their meanders, and winding receffes. But though they require this refrefling at firft; yet do they perfectly abhorall fercoration; nor will they much endure to have the earth open'd about their roots for Ablaqueation, or be difturb'd. This is alfo to be underftood of $C_{y p r e s}$. A Fir for the firft half dozen years feem vance; but it is when throughly rooted, that it comes away miraculoufly. That Honourable Knight Sir Norton Kriatcbbill (whofe delicious Plantation of Pines, and Firs I beheld with great fatisfaction) having affur'd me that a Fir-tree of his raifing, did fhoot nolers then 60 foot in beight in little more then twenty years, is a pregnant inftance, as of the fpeedy growing of that material; fo of all the encouragement I have already given for the more frequent cultivating this ornamental, ufeful and profitable Tree.

10. The Picea is another fort of Pine, and to be cultivated Pitch. like it

\section{Picectantum, taxiǵ, nocentes \\ Interdum, ant edere pandunt Vestigia nigre.}

to fhew in what unprofitable foils they grow; And therefore I 
am not fatisfied why it might not profper in fome tolerable degree in England, as well as in Germany, $R u l \int{ }_{i} a$, the colder Tracts, and abundantly in France : It grows on the Alpes among the Pine; but neither fo tall nor fo upright.

Ix. There is alfo the Piceaster, out of which the greateft ftore of Pitch is boyl'd. The Teda likewife, which is a fort more unctuous, and more patient of the warmer fcituations.

12. The Bodies of thefe being cut, or burnt down to the ground; will emit frequent fuckers from the Roots; but fo will neither the Pine nor Fir.

13. That all thefe, efpecially the Fir, and Pine, will profper well with us is more then probable, becaufe it is a kind of Demonftration that they did heretofore grow plentifully in Cumberland, Cheßjire, stafford, and Lancafbire, where multitudes of them are to this day found intire, buried under the Earth, though fuppos'd to have been o'rethrown and cover'd fo ever fince the univerfal Deluge: For we will not here trouble our Planter with M.Cambderi's 2uerie, Whether there be not fubterraneous Trees growing under the ground? though fomething to be touched anon might feem to excufe the prefumption of it; befides that divers Earths, as well as Waters, have evidently a quality of petrifying wood buried therein.

14. In scotland there is a moft beautiful fort of Fir growing upon the Mountains; of which from that unhappy Perfon the late Marquefs of Argyle I had fent me fome feeds, which I have fown with tolerable fuccefs.

15. For the many and almoft univerfal ufe of thefe Trees both sea, and Luand will plead,

\section{Navigits Pinos-...}

They make our beft Maft, sheatbing, \&c. heretofore the whole Vefel. It is pretty. (faith Pliny) to confider that thofe Trees xabicb are so much jought after for Shipping frould moft delight in the bigheft of Mountains, as if it fled from the Sea on purpose, and pore afraid to dejcend into the Waters. With Fir we likewife make Wainfcot, Floors, Laths, Boxes, and wherever we ufe the Deal; nor does there any $W o o d$ fo well agree with the glew as it, or fo eafie to be wrought: It is alfo excellent for Beams, and other Timber-work. in Houfes, being both light, and exceedingly ftrong, where it may lie dry everlafting, and an extraordinary faver of Oak where it may be had at reafonable price. I will not complain what an incredible mafs of ready Money is yearly exported into the Nortbers Conintrys for this fole commodity, which might all be faved were we induftrious at home. Likewife from $F$ ir we have the moft of our Pot-aßbes.

The Pine, and Piceaburied in the earth never decay : From the latter tranßudes a very bright and pellucid Gum; hence we have likewife Rofin; alfo of the Pine are made Boxes, and Barrels for 
dry Goods; yea, and it is cloven into fringles for the covering of houfes in fome places; not to forget the kernels, of fuch admirable ufe in Emulfions: In fum, they are rlantations which exceedingly improve the Air by their odoriferous and balfamical emiffions, and for ornament create a perpetual spring where they are propagated.

16. But now whiles I am reciting the $v$ Jes of thefe beneficial Trees, Mr. Wintborp prefents the Royal Society with the Proce/s of making the Tar and Pitch in Nem England, which we thus abbreviate.

Tar is made out of that fort of Pine-tree from which naturally Terpentine extilleth; and which at its firt flowing out is liquid and clear ; but being hardned by the air, either on the Tree, or where-ever it falls, is not much unlike the Burgundy Pitch; and we call them Pitch-pines out of which this gummy fubftance tranfudes: They grow upon the moft barren plains, on rocks alfo and bills rifing amongt thofe plains, where feveral are found blown down, that have lain fo many ages as that the whole bodies, branches and roots of the Trees being perilhed, fome certain knots only of the boughs have been left remaining intire (thefe knots are that part where the bough is joyn'd to the body of the Tree) lying at the fame diftance and pofture as they grew upon the Tree for its whole length. The bodies of fome of thefe Trees are not corrupted through age, but quite confum'd and reduc'd to afhes by the annual burnings of the Indians, when they fet their grounds on fire; which yet has, it feems, no power over thefe hard knots beyond a black fcorching; although' being laid on heaps they are apt enough to burn.

It is of thefe knots they make their Tar in Nero England and the Country adjacent, whiles they are well impregnated with that Terebintbine, and Refinous matter, which like a Balfanz preferves them folong fromputrifaction. The reft of the Tree doe indeed contain the like Terebintbine fap, as appears (upon any flight incifion of bark on the ftcm, or boughs) by a fmall cryftaline pearl which will fweat out; but this, for being more watry, and undigefted by reafon of the porofity of the wood, which expofes it to the impreffions of the air and wet, render the Tree more obnoxi: ous; efpecially, if it lye proftrate with the barkon, which is a receptacle for a certain intercutaneous worm that accelerates its decay. They are the knots then alone which the Tar-makers amafs in beafs, carrying them in Carts to fome convenient place not far off, where finding clay or loam fit for their turn, they lay an Heartb of fuch ordinary ftone as they have at hand: This they build to luch an height from the level of the ground, that a $V e f-$ fclmay ftand a little lower then the Hearth to receive the Tar as it runs out: But firft, the Heartb is made wide according to the quantity of knots to be fet at once, and that with a very fmooth floore of clay, yet fomewhat defcending or dipping from the extream parts to the middle, and thence towards one of the fides, where a gullet is left for the Tar to run out at. The Hearth thus 
finifh'd, they pile the knots one upon another, after the very fame manncr as our Colliers do their mood for Char-coal; and of a height proportionable to the breadth of the Heartb; and then cover them over with a coat of loam or clay (which is beff) or in defect of thofe, with the beft, and molt tenacious eartb the place will afford; leaving only a finall $\beta$ iracle at the top whereat to puit the fire in; and making fome little boles round about at feveral heights, for the admiffion of fo much air as is requifite to keep it burning, and to regulate the fire by opening, and ftopping them at pleafure. The proce $\beta$ is almoft the fame with that of making cbar-coal, as will appear in due place; for when it is well on fire, that middle bole is alfo ftopp'd, and the reft of the Regifters fo govern'd as the knots may keep burning and not be fuffocated with too much $\int$ moak, whiles all being now through-heated, the Tar runs down to the Hearth together with fome of the more watry fap, which hafting from all parts towards the middle is convey'd by the foremention'd gutter into the Barrel, or Veffel placed to receive it : Thus the whole Art of Tar-making is no other then a kind of rude diftillation per defcenfum, and might therefore be as well done in Furnaces of large capacity, were it worth the expence. When the Tar is now all melted out, and run, they ftop up all the vents very clofe; and afterwards find the knots made into excellent char-coal preferr'd by the $S$ miths before any other whatfoever which is made of wood; and nothing fo apt to burn out when their blast ceafeth; neither do they parkle in the fire as many other forts of coal do; fo as, in defect of Sea-coal, they make choice of this as beft for their ufe, and give greater prices for it.

Of thefe knots likewife do the Planters fplit out fmall fivers about the thicknefs of one's finger, or fomewhat thinner, which ferve them to burn in ftead of Candles; giving a very good light. This they call Candle-wood, and it is in much ufe both in Ners England, Virginia, and amongft the Dutch-planters in their Villages; but for that it is fomething offenfive by reafon of the much fuliginous fmoak which comes from it, they commonly burn it in the cbiminey-corner upon a flat ftone, or Iron; except, occafionally, they carry a fingle ftickin their hand, as there is need of light to go about the houfe.

It muft not be conceiv'd, by what we have mention'd in the former defcription of the knots, that they are only to be feparated from the bodies of the trees by devouring time; or that they are the only materials out of which Tar can be extracted: For there are in thefe. Tracts millions of Trees which abound with the fame fort of knots, and full of Terpentine fit to make Tar: But the labour of felling thefe Trees, and of cutting out their knots, would far exceed the value of the Tar; efpecially in Countries where Workmen are fo very dear: But thofe knots, above mention'd, are provided to hand, without any other labour then the gathering only.

There are fometimes found of thofe fort of Pine-trees the loweft 


\section{A Difcourje of Foreft-Trees.}

loweft part of whofe ftems towards the root is as full of Terpentine as the knots; and of thefe alfo may Tar be made : but fuch Trees being rarely found, are commonly preferved to fplit into Candle-mood; becaufe they will be eafily riven out into any lengths, and fcantlings defir d, much better then the knots.

There be who pretend an art of as fully impregnating the body of any living Pine-tree for fix or eight foot high: and fome have reported that fuch an art is practis'd in Norway: But upon feveral experiments by girdling the Tree (as they call it) and cutting fome of the bark round, and a little into the wood of the Tree, fix or eight foot diftant from the ground, it has yet never fucceeded; whether the juft feafon of the year were not obferv'd, or what elfe omitted, were worth the difquifition; if at lealt there be any fuch fecret amongft the Norwegians, Swedes, or any other Nation.

Of Tar, by boiling it to a fufficient height, is Pitch made: and in fome places where Rofin is plentiful, a fit proportion of that may be diffolved in the Tar whiles it is boiling, and this mixture is fooneft converted to Pitch; but it is of fomewhat a differing kind from that which is made of Tar only, without other compofition.

There is a way which fome ship-Carpenters in thofe Countries have us'd to bring their Tar into Pitcb for any fudden ufe; by making the Tar fo very hot in an Iron-kettle, that it will eafily take fire, which when blazing and fet in an airy place, they let burn fo long, till, by taking out fome fmall quantity for trial, being cald, it appears of a fufficient confiftence: Then by covering the Kettle clole, the fire is extinguifh'd, and the Pitch is made without more ceremony.

There is a proceßof making Rofin alfo out of the fame knots; by fplitting them out into thin pieces, and then boiling them in mater, which will educe all the Refinows matter, and gather it into a body which (when cold) will harden into pure Rojin.

\section{CHAP. XXII.}

\section{Of the Larch, Platanus, Lotus, ofc.}

I. RUt why might we not hope as well of the Larch from $B$ whence that ufeful drogue Agaric is gather'd. I reade of Beams of nolefs then $\mathbf{I} 20$ foot in length made out of this goodly Tree which is of fo ftrange a compofition that 'twill hardly burn, as Cafar found in a Caftle he befieg'd built of it : yet the Coals thereof were held far better then any other for the melting of Iron. That which now grows fome where about Chelnsford in Effex, arriv'd to a flourifhing, and ample Tree, does fufficiently reproach our negligence and want of industry as well as the inconparable and thady Platanus, that fo beautiful and preci- 
ous Tree which we reade the Romans brought out of the Livant, and cultivated with fo much induftry and coft, for its ftately and proud head only; that they would irrigate them with Wine in ftead of Water; and fo priz'd the very fhadow of it, that when afterwards they tranfplanted them into France, they exacted a Tribute. of any of the Natives who thould prefume but to put his bead under it. Tliny tells us there is no Tree whatfoever which fo well defends us from the beat of the Sun in Summer; nor that admits it more kindly in Winter.

Platanus. T. There was lately at Bafil in Switzerland an ancient goodly Platanetum : and they may with us be rais'd of their feeds with care, in a moift foil, as here I have known them : But the reafon of our little fuccefs is, that we very rarely have them fent us ripe; which fhould be gather'd late in Autumn, and brought us from fome more Levantine parts then Italy.

2. They come alfo of Layers abundantly; affecting a frefh and feeding ground; for fo they plant them about their Rivulets, and Fountains.

Lotus. I. The fame opinion have I of the noble Lotws, which in Italy yields both an admirable froade, and Timber immortal.

2. The offer of CrafJus to Domitius for half a dozen of thefe Trees growing about an houfe of his in Rome, teftifies in what efteem they were had for thcir incomparable beauty and ufe.

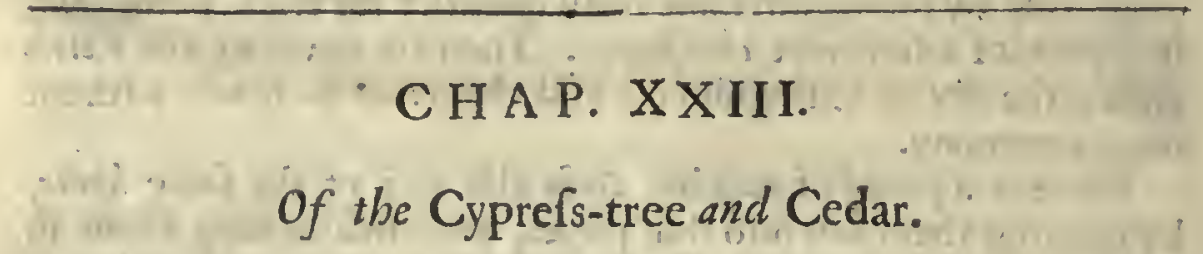

Cyprefs. I. T Fe fhould reafon only from our common experience, even tender, and nice a Plant, that it was cultivated with the greateft care, and to be found only anongtt the Curious; whereas we fee it now, in every Garden, rifing to as goodly a bulk and ftature, as moft which you fhall find even in Italy it felf; for fuch I remember to have once feen in his late Majefties Gardens at Theobalds, before that Princely feat was demolifh'd. I fay, if we did argue from this Topic: Methinks it fhould rather encourage our Country$m e n$ to add yet to their Plantations other Forreign and $n e f u l$ Trees, and not in the leaft deter them, becaufe many of them are not as yet become endenizon'd amongft us:

2. We may read that the Peach was at firft accounted fo tender and delicate a Tree, as that it was believ'd to thrive only in Perfar; and even in the days of Galen it grew no nearer then Egypt, of all the Roman Provinces, but was not feen in the City till more then thirty years before Pliny's time: whereas there is now hardly a more common and univerfal in Europe: Thus likewife the Avella. na from Tontus in Afra; Thence into Greece, and fo Italy, to the City of Abellino in Campania.

Una 
Una tantim litera immutata, Avellina dici, quia priws Abellina.

I might affirm the fame of our Damafco.Plum, Quince, Medlar, Figue, and moft ordinary Pears, as well as of feveral other Peregrine Trees, Fruit-bearers, and otbers. It was 680 years after the foundation of Rome ere Italy had tafted a Cherry of their own, which being then brought thither out of Pontus (as the above-mention'd Filberts were) did afterwards travel ad nltimos Britannos.

3. Fofephus tells us, That the Cedar in Judea was first planted there by Solomon, who doubtless try"d many rare Experiments of this nature; and none more Kingly then that of Planting to Pofterity. I do not fpeak of thofe which grow on the Mountains of Libanws, in the colder and Nortbern tracts of Syria: But, as I am inform 'd by a curious Traveller, there remaining now not above inenty four of thofe ftately Trees in all thofe goodly Forefts, where that mighty Prince fet fourfcore thoufand Hewers at work for the Materials of one only Temple and a Palace, 'tis a pregnant Example what Tine and Neglect will bring to ruine, if due and continual care be not taken to propagate Timber.

4. Nor is it any wonder if we find the whole species of fome Trees fo totally loft in a Countrey as if there had never been any fuch planted in it: Be this therefore applied to Fir, Pine, and many others with us, fince it was fo long ere Rome was acquainted with them, or indeed with any of the Pitch bearers.

5. We had our firft Myrtils out of Greece, and Cyprefs from Creete, which was yet a meer ftranger in Italy, as Pliny reports, and moft difficult to be raifed; which made Cato to write more concerning the culture of it then of any other Tree: Notwithftanding we have in this Countrey of ours.no lefs then tbree forts, which are all of them eafily propagated, and profper very well if they are rightly ordered; and therefore I fhall not omit to difclofe one fecret, as well to confute a popular Errour, as for the Infruction of our Gard'ners.

6. The Tradition is, That the Cypress (being a symbol of Mor tality, they fhould fay of the contrary) is never to be $c u t$ for fear of killing it. This makes them to impale and wind them about like fo many IEgyptian Mnmmies; by which meaps the inward parts of the Tree being heated, for want of Air and Refrefhment, it never arrives to any perfection, but is exceedingly troublefome, and chargeable to maintain; whereas indeed there is not a more tonfile and governable Plant in nature: For the Cyprefs may be cut to the very Roots, and yet fpring afreth: And this we find was the busbandry in the Ifle of Enaria, where they us'd to fell it for Copfe: For the Cyprejs being rais'd from the Nurfery of seeds fown in September (or rather $M$ arch), and within two years after tranjplanted, fhould at two years ftanding more, have the mafter ftem of the middle thaft cut off fome hand-breadth below the fummit, the fides and finaller fprigs thorn into a conique or pyramidal form, and fo kept clipp'd from April to september, as oft as there is occafion; and by this, Reginen they will grow furnifi'd to the foot, and be- 
come the moft beantiful Trees in the world, without binding or Stake; ftill remembring to abate the middle ftem, and to bring up the collateral branches in its ftead to what altitude you pleafe: Thus likewife may you form them into Hedges and Topiary works, or by fowing the seeds in a thallow furrom, and plucking up the fupernumeraries where they come too clofe and thick: For in this soork it thall fuffice to leave them within a foot of each other; and when they are rifen about a yard in height (which may be to the half of your Palifado) cut off their tops, as you are taught, and keep the fides clipp'd, that they afcend but by degrees, and thicken at the bottome as they climbe. Thus they will prefent you in half a dozen or eight years with incomparable bedges, preferable to all others whatfoever, becaufe they are perpetually green, and able to refift the Winds better then any which I know, the Holly only excepted, which indeed has no peer.

7. When I fay Winds, I mean their fierceft $\mathrm{gufts}$, not their cold: For though it be faid, Brumagis ill efa Cupreffus, and that indeed no froft impeaches them(for they grow even on the fnomy tops of $I d a_{0}$ ) yet our cruel Eaftern winds do fometimes mortally invade them which have been late clipp' $d$, feldome the untouch'd, or that were dreffed in the spring only: The effects of this laft March and Aprit Winds,accompanied with cruel Frolts and cold blafts, for the fpace of more then two moneths night and day, did not amongft neer a thoufand cypreffes (growing in my Garden) kill above three or four, which for being very late cut to the quick, (that is, the latter end of october) were raw of their monnds, took cold, and gangreen'd; fome few others which were a little finitten towards the tops, might have efcaped all their blemifhes, had my Gard'ner capp'd them but with a woißp of bay or \$traw, as in my abfence I command$e d$. As for the frost of the paft Winter (then which I believe there was never known a more cruel and deadly piercing fince England had a name) it did not touch a Cypress of mine till it joyn'd forces with that deftructive $W$ ind: Therefore for caution, clip not your Cypreffes late in Antumn, and cloath them againft thefe minds; for the frofts they only difcolour them, but feldome or never hurt thein, as by long experience I have found.

8. If you affect to fee your cyprefs in standard, and grow wild (which may in time come to be of a large fubftance, fit for the moft immortal of Timber ) plant of the Male fort; it is a Tree which will profper wonderfully; and where the ground is hot, and gravelly, though he be nothing fo beautiful.

9. There is likewife the Tarentine Cypre $\beta$, fo much celebrated by Cato: I do not mean our Savine, (which fome erroneoully take for it) both that, and the Milefran, are worthy our culture.

10. I have already thew'd how this Tree is to be rais'd from the feed; but there was another Method amongft the Ancients, who (as I told you) were wont to make great. Plantations of them for their Timber : I have practis'd it my felf, and therefore deferibc it.

II. If you receive your feed in the Nuts, expofe them to the 
sun till they gape, or neer a gentle fire, by which means the feeds will be eafily thaken out; for if you have them open before, they do not yield you half their crop,

About the beginning of April (or before, if the weather be Showpery) prepare an even Bed, which being made of fine earth, clap down with your Spade, as Gard'ners do for Purfelain-feed: (of old they roll'd it with fome Stone or Cylinder) Upon this ftrew your feeds pretty thick; then fieft over them fome more mould for almolt an inch in height : keep them duly watered after Sun- $\int e t$, unlefs the feafon do it for you; and after one years growth (for they will be an inch high in little more then a Moneth) you may tranplant them where you pleafe.

12. What the ves of this Timber are, for Chests and other Vtenfils; as heretofore for Supporters of Vines, Poles, Rails, and Planks, (refifting the Worm, Moth, and all putrefaction to eternity) the Venetians fufficiently underftand; who do every twenty year, and oftner (the Romans every thirteen) make?a confiderable Revenue of it out of Candy: And certainly a very gainful commodity it was, when the Fell of a Cyprefetum was heretofore reputed a good Daughters Portion, and the Plantation it felf call'd Dotem filia.

13. The Timber of this mood was of infinite efteem with the Ancients : That lafting Bridge built over the Euphrates by Semiramis was made of this wood; and it is reported, Plato chofe it to write his Lams in before Braß it felf, for the diuturnity of the matter : It is certain, that it never rifts, or cleaves, but with great violence; and the bitterne $\beta$ of its juice preferves it from all worms, and putrifaction. To this day thofe of Creet, and Malta make ufe of it for their buildings; becaufe they have it in plenty, and there is nothing out-lafts it: Finally, (not to forget even the very chips of this precious wood, which gives that flavour to Mufcadines and other rich Wines) I commend it for the improvement of the Air, as fending forth molt fweet, and aromatick emiflions, when ever it is either clipp'd, or bandled : But,

\section{if I forget}

2uid tibi odorato referam fudantia ligno,

The Cedar? which grows in all extreams: In the moift Barbados; the hot Bermudas, the cold New England; even where the Snow Cedar. lyes (as I am aflur'd) almoft half the year: Why then it fhould not thrive in Old England, I conceive is from our want of indilftry: It grows in the Bogs of America, and in the Mountains of Afia : It leems there is no place affrights it; and I have frequently rais'd it of the feeds, which I fet like the Bay-berries; and we might have of the very best kind in the World from the summer Iflands, though now almoft utterly exhaufted there alfo, and fo the moft incomparable of that facred wood like to be quite deftroy'd by our Negligence, which is by nature almofteternal:

3. Thus I reade that in the Temple of Apollo at Vtica there was found Timber of neer two thoufand years old; and in sagunti of spain a beam in a certain Oratory confecrated to Diana, which had 
been brought from $Z$ ant 200 years before the deftruction of Troy:

4. The Sittim mention'd in holy Writ is believ'd to have been a kind of Cedar, of which the moft precious Vtenfils were form'd; fo that when they faid a thing was cedro digna, the meaning was, worthy of eternity:

\section{CHAP. XXIV.}

\section{Of the Cork, Alaternus, Phillyrea, Granad, Myrtil, Jafmine, occ.}

Cork. I. THe Cork[Suber $]$ grows in the coldest parts of Bifcany, and in 2. I the North of New England: Why fhould we delpair? That the great Ilex thrives well enough, his Majefties Privy-gardens at White-hall would once have fhew'd, where ftood a goodly Tree, of more then fourfcore years old; though there be now but an Impe of it remaining. I wonder Carolus Stephanus, and Benedictus Curfins hould write fo confidently there were no Cork-trees in Italy, where I my felf have travell'd through vaft Woods of them about Pifa, and Aquin, and in divers other places between Rome and the Kingdom of Naples: That there were none in France indeed Pliny is exprefs, Nat. Hist.l. 16.c.8.

3. I hall not need rehearfe the $v$ fes of the Bark of this Tree, it is fo well known; the Timber is elfe inconfiderable.

Alaternus. I. The Alaternus, which we have lately receiv'd from the hotteft parts of Laniguedoc (and that is equal with the heat of almoft any Country in Europe) thrives with us in England, as if it were an Indigene and Natural.

2. I have had the honour to be the firft who brought it into Vee and reputation in this Kingdom for the moft beautiful, and ufeful of Hedges, and Verdure in the world (the friftne $\beta$ of the growth confider'd) and propagated it from Cornwall even to Cunnberland: The feed grows ripe with us in Auguft; and the honybreathing Bloffomes afford an early and marvellous relief to the Bees.

Pbillyres. I. All the Phillyrea's are yet more hardy; which makes me wonder to find the Angustifolia planted in Cafes, and fo charily fet into theftoves, amongtt the Oranges and Lemzzons; when by long experience I have found it equal our Holly in fuffering the extreameft rigours of our cruelleft Frosts, and Winds, which is doubtlefs (of all our Englifh Trees) the moft infenfible and ftout.

2. They are (both Alaternus and this) raifed of the feeds (though thofe of the Phillyrea will be long under ground) and being tranfplanted for Eppalier hedges, or standards, are to be govern'd by the Jears, as oft as there is occafion : The Alaternus will be up in one Moneth after it is fown: Plant it out at two years growth, and clip it after rain in the $\beta$ ring, before it grows fticky, 


\section{A. Difcourfe of Foreft-Trees.}

and whiles the thoots are tender; thus will it form an bedge (though planted but in fingle rows and at two foot diftance) of a yard in thicknefs, twenty foot high (if you defire it) and furnifh'd to the bottom: But for an hedge of this altitude, it would require the friendihip of fome $W$ all, or a Frame of lufty poles, to fecure againft the Winds one of the moft delicious objects in nature: But if we could have ftore of the Pbillyrea folio leviter ferrato (of which I have rais'd fome very fine Plants from the feeds) we might fear no weat ber; and the verdure is incomparable.

I. The culture of the Granade does little differ from that Granade. of the Alaternus, of which we might raife confiderable bedges on all our Southern Afpects. : They have fupported this laft moft unmerciful Winter without any artifice; and if they yield us their flowers for our pains of well pruning (for they muft diligently be purged of their wood) it is a glorious recompence: 'I plant them in my Hedge-rows even amongft the 2uick.

I. The vulgar Italian wild Myrtil(though not indeed the moft Myrtil. fragrant) grows high, and fupports all weathers. I know of one neerfifty years old, which has been continually expos'd; unlefs it be, that in fome exceeding Jharp feafons a little ftraw has been thrown upon it; and where they are fmitten, being cut down neer the ground, they put forth and recover again; which many times they do not in Pots, and Cajes, where the roots are very obnoxious to perilh with mouldineßs. The fhelter of a few Mats, and straw, fecur'd very great Trees (both leaf and colour in perfection) this laft Winter alfo, which were planted abroad; whiles thofe that were carried into the conferve were molt of them loft. Myrtils may be rais'd of feeds, but with great caution; and they feldom prove hardy, nor is it worth the time being fo abundantly encreafed of Layers : But,

2. I produce not thefe particulars, and other amana vireta al-

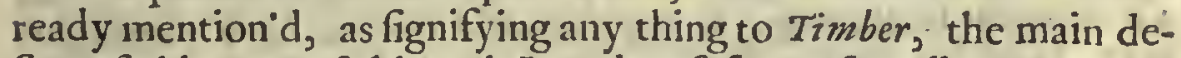
fign of this Treatife (though I reade of fome fo tall, as to make make spear foafis) but to exemplifie in what may be farther added to ornament and Pleafure by a cheap, and moft agreeable induftry.

The common white and yellow Fafmine would flower plenti- Fafmine. fully in our Woods, and is as hardy as any of the Periclimena; (how it is propagated by fubmerfion, or layers, every Gard'ner skills; and if it were as much imploy'd for Noje-gays, buc. with us, as it is in France and Italy, they might make money enough of the Flowers : One forry tree in Paris, where they abound, has been worth to a poor woman neer tmenty thillings in a year.

CHAP. 


\section{CHA P. XXV.}

\section{Of the Acacia, Arbutus, Bays, Box, Yew, Holly, Juniper, and Laurel-trees.}

Acacia. I. THe French have larely brought in the Virginian Acacia, which exceedingly adorns their Walks : The Tree is hardy againft all the invafions of our tharpeft feafons, but our high winds; which by reafon of its brittle nature it does not fo well refift; and the Roots (which infinuate and run like liquorize under ground) are apt to emaciate the foil, and therefore haply not fo commendable in our Gardens, as they would be agreeable for variety of Walks and thade : They thrive well in his Majesties new Plantation in St. Fames's Park.

Arbutus. $\quad$ I. But why do we thus neglect the Arbutus, and make that fuch a rarity, which grows fo common, and fo naturally in Ireland? It is indeed with fome difficulty rais'd from the feeds; but it may be propagated from the Layers, grows to a goodly Tree, and is patient of our fevereft weather.

Bayt. I. Bays are encreas'd both of their suckers, and seeds, which thould be dropping-ripe ere gather'd : Pliny has a particular pro$c e \beta$ for the ordering of the feeds; and it is not to be rejected: Which is, the gathering the Berries dry, in Fanuary, and fpreading them till their fweat be over : then he puts them in dung and fows them: : As for the fteeping in wine, water does altogether as well : others wafh the feeds from their mucilage, by breaking and bruifing the glutinous Berries; then fow them in March by fcores in a heap; and indeed fo they will come up in clusters, but nothing fo well, nor fit for tranßlantation, as where they are interr'd with a competent fcattering, fo as you would furrow reafe: Both this way, and by fetting them apart (which I molt commend) I have rais'd multitudes, and that in the berries without any far-

2. ther preparation; only for the firft two years they would be defended from the piercing winds which frequently deftroy them; and yet the fcorching of their tender leaves ought not make you defpair, for many of them will recover beyond expectation.

3. This aromatic Tree greatly loves the fade, yet thrives beft in our hotteft Gravel, having once pafs'd thofe firft difficulties: Age and Culture about the roots wonderfully augment its growth; fo as I have feen Trees neer thirty foot high of them; and almoft two foot diameter. They are fit alfo both for Arbour and $P$ alifade-work, fo the Gard'ner underitand when to prune, and kecp it from growing too woody.

Box. I. The Box which we begin toprofcribe our Gardens, fhould not yet be banifh'd from our care; becaufe the excellency of the mood does commute for the unagreeablenefs of its fmell: thercfore, let us furnith our cold, and barren Hills, and declivities with this ufeful strub: It will increale abundantly of fips fet in March. 
2. The Turner, Ingraver, Matbematical-Inftrument, Comb and Pipe-makers give great prizes for it by meight, as well as meafure; and by the feafoning, and divers manner of cutting, vigorous infolations, politure and grinding, the Roots of this Tree (as of even our common; and neglected Thorne) do furnith the Inlajer and Cabinet-makers with pieces rarely indulated, and full of variety: -3. The Gbymical oyl of this mood has done the feats of the beft Grajacunz (though in greater quantity) for the cure of Venereal difeafes, as one of the moft expert Phyfitians in Europe has confefs'd.

I. Since the ufe of . Bams is laid afide amongft us, the propaga- Eugt. tion of the Eugh-triee is likewife quite forborn; but the neglect of it is to be deplar'd; feeing; that (befides the rarity of it in Italy? and France, where but little of it grows) the barreneft grounds, and coldeft of our monntains (for

Aquilonem of frigorataxi) might be profitably replenilh'd with them: I fay, profitably, for, befides the ufe of the roood for Bows

Ityreos taxi torquentur in arcws. The foremention'd Artists in Box moft gladly imploy it: And for the cogs of Mills, Posts tu be fet in moift grounds, and everlafting Axle-trees, there is none to be compar'd with it, likewife for the bodies of Lutes, Theorbas, Erc. yea; and for Tankards to drink out of, whatever Pliny report of its ßoade, and fatal fruit. in spain, France. and Arcadia.

2. The toxic quality was certainly in the liquor. which thofe good Fellowos tippl'd out of thore bottles, not in the nature of the mood; which yet he affirms is cur'd of that Venenows quality by driving a brazein medge into the body of it : This I have never trid, but that of the Shade and fruit I have frequently, without' any dendly, or noxious effects : fo that I am of opiniop that Tree which sefizus calls Smilax, and our Historian thinks to be our Eugh, was fome other Wood.

3. This Tree is eafily produc'd of the feeds, walh'd and cleans"d from their mucilage; and burried in the ground like Habos; It will commonly be the fecond Winter ere they peep, and then' they rife with their caps on their beads: Being three years old you may tranplant thein, and form them into standards, Knobs, Walks, Hedges, \& c. in all which works they fúcceed mârvellous well, and are worth our patience for their perennial verdure, ant durableneß.

4. He that in Winter hould behold fome of our higheft Hills in Surrey clad with whole Woods of thefe two latt fort of Trees, for divers Miles in circuit, (as in thofe delicious Groves of them, belonging to the Honourable my noble friend Sir Adam Bromn of Bech-porth-Castle, from Box-bill, and neer our famous Mole or Sroallow) might without the leaft violence to his Imagination, eafily phanfie himfelf tranfported into fome new or enchanted Country; for, if in any $\int$ pot of England,

Hîc ver perpetunm, atque alienis menflbus aftas. 
'Tis here

Eternal spring, and summer all the year:

$H$ vy.

1. But, above all the natural Greens which inrich our homeborniftore, there is none certainly to be compar'd to the Holly; infomuch as I have often wonder'd at our Curiofity after forreign Plants, and expenfive difficultics, to the neglect of the culture of this vulgar, but incomparable Tree; whether we will propagate it for $v \int_{e}$, and Defence; or for jight and ornament.

2. Is there under beaven a more glorious ánd refrefhing object of the kind, than an impregnable Hedge of one.buzdred and fixty foot in length, feven foot high, and five in diameter, which I can Thew in my poor Gardens at any time of the year, glitt'ring with its arm'd and vernifh'd leaves? the taller standards at orderly diftances blufhing with their natural Corall: It mocks at the rudeft affaults of the Weather, Beafts, or Hedge-breaker,

\section{Et illum nemo impunè lace $\int$ it.}

3. I have already thew'd how it is to be rais'd of the Berries, when they are ready to drop: Remove them alfo after three or four years; but if you plant the sets (which is likewife a commendable way, and the Woods will furnilh enough.) place 'em Nortbrards, as they do Quick. Of this might there lining Pales and Enclofures be made (fuch as the Right Honourable my Lord Dacres, fomewhere in sufJex, has a Park. almof environ'd with, able to keep in any Game, as I am credibly inform'd) and cut into fquare Hedges, it becomes impenetrable, and will thrive in botteft as well as the coldeft places. At Dengeneffe in Kent they grow naturally amongt the very beach, and pibbles: And this rare Hedge, the boaft of iny Villa, was planted upon a burning gravel, expos'd to the méridian Sun:

4. True it is, that time mutt bring this Tree to perfection; it does fo to all things elfe, or pofteritati pangimus. But what if a little culture about the Roots (not dunging, which it abhorres) and frequent firring of the mould doubles its growth? We fay even years for a tolerable Quick, it is worth ftaying it thrice for this, which has no competitor.

5. And yet there is an expedient to effect it more infenfibly, by planting it with the 2uick: Let every fift or fixt be an Holly-fet, they will grow up infallibly with your Quick, and as they begin tolpread, makeway for them, by extirpating the Wbite-tborn, till they quite domineer : Thus was my Hedge firft planted, without the lcaft interruption to the Fence, by a moft pleafant Metamorphofis. But there is alfo another, not lefs applauded, by laying along of well rooted sets (a yard or more in length) and ftripping off the leaves and branches: thefe cover'd with a competent deptl of earth will fend forth innumerable suckers which will fuddenly advance into an Hedge.

6. The 
6. The Timber of the Holly is for all fturdy ufes; the MillWright, Turner and Engraver prefer it to any other: It makes the beft handles, and ftocks for Tools, and of the Bark is compos'd our Bird-lime.

I. Of Juniper we have two forts, whereof one is much taller, funiper: and more fit for Improvement: The wood is yellow, and fweet as Cedar, whereof it is accounted a dwarfifh fort.

2. I have rais'd them abundantly of their $\int e e d s$, which in two moneths will peep, and being govern'd like the cypre $\int e$, apt for all the employments of that beautiful Tree: The difcreet loofening of the Earth about the Roots alfo makes it ftrangely to prevent your expectations by fuddenly fpreading into a $b u j h$ fit for a thoufand pretty Employments; for coming to be much unlike that which grows wild, and is fubject to the treading and cropping of Cattle, \&uc. it may be form'd into moft beautiful and ufeful Hedges: My Brother having cut out of one oncly Tree an Arbour capable for three to fit in: It was at my laft meafuring feven foot fquare, and eleven in height; and would certainly have been of a much greater altitude and farther fpreading, were it not continually kept jorn: But what is moft confidetable is the little time fince it was planted, being yet hardly ten jears, and then it was brought out of the Common a flender Bufb of about two foot highs But I have experimented a proportionable improvement in my own Garden, where I do mingle them with $c_{y p r e} \int c_{c}$, and they perfeetly become their ftations.

3. The Berries afford (befides a tolerable Pepper) one of the moft univerfal Remedies in the world to our crazy Forefter; and the Coals, which are made of the $\mathrm{Wood}$, endure the longeft of any: If it arrive to full growth it is Timber for many curious works; the very chips render a wholefom perfume within doors, as well as the dufty bloffoms in spring without.

I. But to Cromn all, I will conclude with the Laurell, which Laurel. by the $v \int e$ we commonly put it to, feems as if it had been only deftin'd for Hedges, and to cover bare Walls; whereas, being planted upright, and kept to the standard, by cutting away the collateral Branches, and maintaining one ftem, it will rife to a very confiderable Tree; and (for the firft twenty years) refembling the moft beautiful headed Orange in Shape and verdure, arrive in time to emulate even fome of our lufty Timber-trees; fo as I dare pronounce the Laurel to be one of the moft proper and ornamental Trees for Walks and Avenues of any growing.

2. Pity it is they are fo abus'd in the Hedges, where the lower Branches growing ftickie and $d r y$, by reafon of their frequent and unfeafonable cutting (with the genius of the Tree, which is to (pend much in wood) they never fucceed after the firft $\int 2 x$ or feven years; but are to be new planted again, or abated to the very Roots for a frefh $\beta$ hade.

3. But would you yet improve the standard which I celebrate, to greater and more fpeedy exaltation? bud your Liurel on the Black-cherry-jtock to what height you pleafe; if at leaft the re- 
port be true, which $I$ had from an ocular teftimony, and am now making an effay of, becaufe I am more then fomewhat doubtful of fuch Allyances, though fomething like it in Palladius fpeaks it not fo impoffible;

\section{Inferitur lauro Cerajus, partuǵg coacto Tiugit adoptivus virginis ora pudor.}

4. They are rais'd of the seeds or Berries with extraordinary facility, or propagated by Layers and enttings where-ever there is thade and moifture. I have finifh'd now my Planting: A word or two concerning their Prefervation, and the Cure of their Infirmities.

\section{CHAP: XXVI.}

\section{Of the Infirmities of Trees.}

Infirmities. THe Difeafes of Trees are various, affecting the feveral parts: 1 Thefe invade the Roots; Weeds, suckers, Fern, Wet, Mice, and Moles.

I. Weeds are to be diligently pull'd up by hand after Rain, whiles your Seedlings are very young, and till they come to be able to kill them with forde and over-dripping: And then are you for the obstinate to ufe the Haw, Fork, and Spade, to extirpate Doggraßs, Bear-bind, \&c.

2. Suckers thall be duly eradicated, and with a tharp fpade dexteroufly feparated from the Mother-roots, and Tranfplanted in convenient places for propagation, as the Seafon requires.

3. Fern is beft deftroy'd by friking off the Tops, as Tarquin did the beads of the poppies: This done with a good mand or cudgel, at the decreafe in the spring, and now and then in summer, kills it in a year or two beyond the vulgar way of Mowing, or burning, which rather encreafes then diminifhes it.

4. Over-much Wet is to be drain'd by Trenches, where it infefts the Roots of fuch kinds as require drier ground : But if a drip do fret into the body of a Tree by the head, (which will certainly decay it) cutting firft the place fmooth, ftop and cover it with loam and bay till a new bark fucceed:

Thefe infeft the Bark; Bark-bound, Teredo, or Worm, Conys, $\pi i o \beta_{3}, I v y, \& c$.

5.The Bark-bound are to be releafed by drawing your knife rinddeep from the Root, as far as you can conveniently; and if the gaping be much, filling the rift with a little Cow-dung; do this on each fide, and at Spring, February or March; alfo cutting off fome branches is profitable; efpecially fuch as are blasted or lightning-fruck. 
6. The Teredo, Coffi, and other Worms, lying between the Body and the Bark, poyfon that paffage to the great prejudice of fome Trees; but the boles being once found, they are to be taken out with a light Incifiow.

7. Conies and Hares by barking the Trees in hard Winters fpoil very many tender Plantations : Next to the utter deftroying them there is nothing better then to anoint that part which is within their reach with ftercus bumanum, tempered with a little Water or Vrine, and lightly brufhed on; this renew'd after every great Rain.

8. Mo/s is to be rubb'd and fcrap'd off with fome fit inftrument of $\mathrm{Wood}_{2}$ which may not excorticate the Tree, or with a piece of Hair-cloth after a fobbing Rain: But the moft infallible Art of Emufcation is taking away the canfe, which is fuperfluous moifture in clayie and fpewing grounds.

9. Ivy is deftroy'd by digging up the Roots, and loofning its hold : Mifsleto, and other Excrefcences to be cut and broken off.

ro. The Bodies of Trees are vifited with Canker, Hollonnefs, Hornets, Earmigs, Snails, \&x.

I. Cankers (caufed by fome froak or galling) are to be cut out to the quick, the fcars emplaiftred with Tar mingled with oil, and over that a thin fpreading of loam; or elfe with clay and Horf-dung; or by laying Wood-afhes, Nettles, or Fern to the roots, $\sigma^{u} c$.

I 2. Hollowne $\beta$ is contracted when by reafon of the ignorant or carelefs lopping of a Tree the wet is fuffer'd to fall perpendicularly upon a part, efpecially the Head: In this cafe if there be fufficient found wood cut it to the quick and clofe to the body, and cap the bollow part with a Tarpaulin, or fill it with good fiff loam and fine bay mingled. This is one of the worft of Evils, and to which the Elm is moft obnoxious.

13. Hornets and Waps, duc. by breeding in the hollowners of Trees infelt them, and are therefore to be deftroy'd by ftopping up their entrances with Tar and Goof-dung, or by conveying the fumes of brimftone into their Cells.

14. Earwigs and Snails dofeldome infent Foreft-trees, but thofe which are Fruit-bearers, and are deftroy'd by enticing them into fweet waters, and by picking the snails off betimes in the Morning, and rainy Evenings. Laftly,

Branches, Buds, and Leaves extreamly fuffer from the Blasts, Faundies, and Caterpillars, Rooks, \&c.

15. The blafted parts of Trees are to be cut away to the quick; and to prevent it, fmoak them in fufpicious weather, by burning moift fraw with the wind, or rather the dry and fuperfluous cnttings of Arromatick plants, fuch as Rofemary, Lavender, Funiper, Bays, \&c.

Mice, Moles, and Pifmires caufe the Faundies in Trees, known by the difcolour of the Leaves and Buds.

16. The Moles may be taken in Traps, and kill'd,as every Woodman knows: It is certain that they are driven from their baunts by Garlick for a time, and other heady fmells buried in their palfages.

17. Mice 
17. Mice with Traps, or by finking fome Veffel almoft level with the furface of the ground, the Veffel half full of Watcr, upon which let there be ftrew'd fome buls or chaff of oates; alfo with Bane.

18. Deftroy Pifmires with falding water, and difturbing their bills.

19. Caterpillars, by cutting off their mebs from the twigs before the end of February, and burning them; the fooner the better: If they be already batched wath them off, or choak and dry them with jmoak.

20. Rooks do in time, by pinching off the buds and tops of Trees for their Nefts, caufe many Trees and Groves to decay.

Thefe (amongft many others)are the Infirmities to which ForeftTrees are fubject whilf they are ftanding; and when they are fell'd, to the Worm; efpecially if cut before the Sap be perfectly at reft: But to prevent or cure it in the Timber, I recommend this secret as the moft approv'd.

21. Let cominor yellow sulphur be put into a cucurbit-gla $s_{\text {, }}$ upon which pour fo much of the frongeft Aqua-fortis as may cover it three fingers deep : Diftil this to drynefs, which is done by two or three Recfifications: Let the sulpbur remaining in the bottom (being of a blackifh or fad red colour) be laid on a Marble, or put into a Glafs, where it will eafily diffolve into Oil: With this anoint what is either infected or to be preferved of Timber. It is a great and excellent Arcausm for tinging the Wood with no unpleafant colour, by no Art to be wathed out; and fuch a prefervative of all manner of Woods, nay of many other things; as Ropes, Cables, Fifhing-nets, Mafts of ships, \&uc. that it defends them from putrefaEion, either in Waters, under or above the earth, in the snom, Ice, Air, Winter or Summer, \&c.

It were fuperfluous to defcribe the process of the Aqua-fortis; It thall be fufficient to let you know, That our common Coperas makes this Aqua-fortis well enough for our purpofe, being drawn over by a Retort : And for sulphur the Ifland of Sichriftophers yields enough (which hardly needs any Refining) to furnith the whole world. This secret (for the Curiows) I thought fit not to omit; though a more compendious three 22. or four anointings with Linfeed oil, has prov'd very effectual : It was experimented in a Wall-nut Table, where it deftroy'd millions of Worms immediately, and is to be practis'd for Tables, Tubes, Mathematical Instruments, Boxes, Bedfteads, Chairs, Rarities, \&x. oyl of Wall-nuts will doubtlefs do the fanc, is fweeter, and a better Vernifls; but above all is commended Oyl of Cedar, or that of Juniper.

Hitherto I have fpoken of Trees, their kinds, and propagation in particular: Now a mord or two concerning their ordering in general, as it relates to Copjes, Lopping, Felling, \&c.

Then I thall add fomething more concerning their $\mathcal{V} \int e$, as to Fewel, \&c. and caft fuch accidental Lefjons into a few Aphorifins, as could not well be inore regularly inferted. 
Laftly, I fhall conclude with fome more ferious obfervations in reference to the main Defign and project of this Difcourfe, as it concerns the Improvement of His Majesties Forelts, for the bonour and fecurity of the whole Kingdom.

\section{CHAP. XXVII。}

\section{of Copfes.}

1. Crlva cadua is as well Copse to cut for Femel as for ufe of copfes.

1. Timber; and we have already thew'd how it is to be rais $d$, both by Sowing and Planting. Our ordinary copfes are chiefly upon Hafel, or the Birch; but if amongft the other kinds ftore of $A$ fh and Sallow (at leaft one in four) were fprinkled in the planting, the profit would foon difcover a difference, and well recompence the Induftry. "Others advife us to plant fhoots of sallow, Willow; Alder, and of all the fwift growing Trees, being of feven years growth, floping off both the ends towards the ground to the length of a Billet, and burying them a reafonable depth in the earth. This will caufe them to put forth feven or eight branches, each of which will become a Tree in a fhort time, efpecially if the foil be moift.

2. Copses being of a competent growth, as of twelve or fifteen years, are efteem'd fit for the $A x$; but thofe of tmenty -years ftanding are better, and far advance the price. Some of our old clergy Spring-woods heretofore have been let reft till twenty five or thirty years, and have prov'd highly worth the attendance; for by that time even a Seminary of Acorns will render a confiderable advance, as I have already exemplified in the Nortbamptonfoire Lady. And if Copfes were fo divided as that every year there might be fome fell $d$, it were a continual and a prefent profit : Seventeen years growth affords a tolerable Fell; fuppofing the Cop $\sqrt{\varepsilon}$ of feventeen Acres, one Acre might be yearly fell'd for ever; and fo more, according to proportion.

3. As to what Numbers and scantlings you are to leave on every Acre, the statutes are our generall guides, at leaft the legal. It is a very ordinary Copfe which will not afford three or four Firfts, that is, Befts; fourteen seconds; twelve 7 hirds; eight Wavers, \&c. according to which proportions the fzes of young Trees in Copfing are to fucceed one inother. By the statute of 35 Hen. 8. in Copses or Under-moods fell'd at twenty four years growth, there were to be left twelve standils, or Stores of $0 a k$, upon each Acre; in defect of fo many Oaks, the fame number of Elms, Af, $A$ P, or Beech; and they to be fuch as are of likely Trees for Timber, and of fuch as have been fpar'd at fome former Felling, unlefs there were none, in which cafe they are to be then left, and fo to continue without Felling till they are ten inch fquare within a yard of ground. 
Cop $\int e s$ above this growth fell'd, to leave 12 great $0 a k s$; or in defect of them other Tinber-trees (as above) and fo to be lefe for 20 years longer, and to be enclofed feven years.

4. In fumme, you are to fpare as many likely. Trees for Timber as with difcretion you can. And as to the felling, (beginning at one fide, that the Carts inay enter without detriment to what you leave ftanding) the Under-wood may be cut from January at the lateft, till mid-31arch, or April's or from mid-September, till neet the end of November; fo as all be avoided by Midfomer at the lateft, and then fenced (Where the Rowes and Brufh lye longer unbound or made up, you endanger the lofs of a fecond spring) and not to fay fo long as ufually they are a clearing, that the roung, and the seedlings may fuffer the leaft interruption.

5. It is advis d not to cut off the Brome-noood of Oaks in Copfes, but to fuffer it to fall off, as where Trees ftand very clofe it ufually does: I do nut well comprehend why yet it fhould be $\int p$ ared fo long.

- 6. When you efpy a clufter of Plants growing as it were all in a.bunch, it thall fuffice that you preferve the faireft sapling, cutting all the reft away. And if it chance to be a Cheß-nut, service, or like profitable Tree, cleer it from the droppings and incursbrances of other Trees, that it may thrive the better: Then 25 you pals along, prune, and trim up all the young Wavers, covering fuch Roots as lye bare and expos'd with frefh mould.

7. Cut not above balf a foot from the Ground, and that lopewife; fripping up fuch as you $\beta$ are from their extravagant Eranches, Water-boughs, \&uc. that hinder the growth of others: Always remembring (before you fo much as enter upon this work), to preferve fufticient Plafh-pole about the verge and bounds of the Copfe.for Feince, and fecurity of what you leave; and for this fomething lefs then a Rod may fuffice: Then raking your Wood cleer of spray, chips, and all Incumbrances, thut it up from the Cattle; the longer the better.

8. By the Statute men were bound to enclofe Copfes after Felling, of or under 14 years growth for 4 years: Thofe above 14 years growth to be 16 years Enclos'd: And for Woods in common, a fourth part to be Thut up; and at Felling the like proportion of great Trees to be left, and 7 years Enclos ${ }^{\circ} d$ : This was enlarg'd by 13 Eliz.

Your elder Under-woods may be graz'd about 7 uly:

Then for the Meajure of Fuel thefe proportions were to be obferv'd.

9. Statutable Billet thould hold three foot in length, and feven inch and half compafs; 10 or 14 as they are counted for 1,2 , or 3, doc.

A ftack of Wood (which is the boughs and offal.of the Trees to be converted to Charcoal) is 4 yards long, three foot and balf high, (in fome places but a yard) and as much over: In other places the Cord is 4 foot in beight and 4 foot over; or, (to fpeak more Geometrically) a sold made up of three dimenfions, 4 foot high, 
four broad, and cight foot long; the content I2 8 cubigue feet.

Fagots ought to be a full yard in length, and two foot in circumference, inade round, and not flat; for fo they contain lefe Fuel, though equal in the bulk appearing. Bit of thefe particilars when we come to fpeak exprefly of Fuel.

ro. In the mean time it were to be.wifh'd, that fome approv'd Experiments were feduloully try'd (with the advice of (kilful and ingenious Phyftians) for the making of Beer' without Hops; as polfibly with the white Marrubium (a Plant of fingular virtue) or with dry'd Heath-tops (viz. that fort which bears no Berries.) or the like, far more wholefom; and lefs bitter then either Tamairisk, Carduws, or Broom, which divers have eflay'd; it might prove a means to fave a world of Fuel, and in divers places young Timber and Copse-rooid, which is yearly fpent for Poles; efpecially in Countries where Wood is very precious.

\section{CHAP. X XVIII.}

\section{Of Pruning.}

I. Runing I call all purgation of Trees from what is fuperflu-Pruning ous. The Ancients found fuch benefit in Pruning, that they feign'd a Godeßs præfided over it, as Arnobius tells us: And in truth, it is in the difcreet performance of this Work that the Improvement of our Timber and Woods does as much confint as in : any thing whatfoever. A fkilful Planter fhould therefore be early at this work: Shall old Gratius give you Reafon and Direcfion?

$$
\begin{aligned}
& \text { Nunquam Jponte fua procerus ad vera termes } \\
& \text { Exiit, inque ipja curvantur ftirpe genifte. } \\
& \text { Ergo age luxuriam primo feetufque nocenteis } \\
& \text { Detrabe: frondofas gravat indulgentiajluas. } \\
& \text { Poft ubi proceris generofa ftirpibus arbor } \\
& \text { se dederit, terete } q u e \text { ferent ad fidera virg } \dot{\dot{\alpha}} \text {, } \\
& \text { stringe notas circum, ou gemmantcis exige verfus. } \\
& \text { His, fi quis vitium nociturus fufficit bumor, } \\
& \text { Vifceribus fluit, ơ venas durabit inertes. . Gra.fal. }
\end{aligned}
$$

And his incomparable Interpreter thus in Englifh.

Twigs of themfelves never rife ftrait and high, And Under-woods are bow'd as firft they thoot. Then prune the boughs; and suckers from the root Difcharge. The leavy wood fond pity tires; After, when with tall rods the tree alpires, Aud the round ftaves to heaven advance their twigs, Pluck all the buds, and frip off all the fprigs; 
Thefe iffues vent what moifture fill abound, And the veins unimploy d grow hard and found.

Wafe.
-1.2. For 'tis a mifery to fee how our faireft Trees are defac'd, and mangl'd by unkilful Wood-men, and mifchievous Bordurers, who go always arni'd with fhort Hand-bills, hacking and chopping off all that comes in their way; by which our Trees are made full of knots, boils, cankers, and deform'd bunches, to their utter 'deftruction : Good busbands thould be afham'd of it. As much to be reprehended are thofe who either begin this work at unfeafonable times, or fo maim the poor lranches, that either out of lazinefs, or want of flill, they leave moft of them. ftubs, and inftead of cutting the Arms and Branches clofe to the boale, hack them off a foot or two from the body of the Tree, by which means they become hollow and rotten, and are as fo many conduits to receive the Rain and the Weather, which perifhes them to the very head, deforming the whole Tree with many ugly botches, which fhorten its life, and utterly marre the Timber.

3. By this Animadverfion alone it were eafie for an ingenious man to underftand how Trees are to be govern'd; which is in a word, by cutting clean, fmooth, and clofe, making the ftroke upward, and with a tharp Bill, fo as the weight of an untractable bough do not $\beta$ plice, and carry the bark with it, which is both dangerous and unfightly.

3. The proper feafon for this work is a little after the cbange in Fanuary:

\section{- Tunc ftringe comas, tunc brachia tonde: \\ Exerce Imperia, Jumos compefce fucnteis.}

But this ought not to be too much in young Frrit-trees, after they once come to form a handform bead; $;$ in which period you fhould but only pare them over about March, to cover the ftock the fooner, if the Tree be very choice: To the aged, this is plainly a renewing of their routh, and an extraordinary refrefhment: Befides, for Interlucation, exuberant branches, \&u $\beta$ piffee nemorum come, where the bonghs grow too thick and are cumberfome, to let in the Sun and Air, this is of great importance.

5. Divers other precepts of this nature 1 could here enumerate, had not the great experience, faithful and accurate defcription how this neceflary Work is to be perform'd, fet down by our Country-man honeft Law Jon (orchard, cap. I I.) prevented all that the moft Inquifitive can fuggeft: The particulars are fo ingenuous, and highly material, that you will not be difpleas'd to read them in his own ftylc.

Gll ages (faith he) up Rules and experience do tonfent toa pruning, ano lopping of Trees: Bat babe not anp tbat 31 knutw

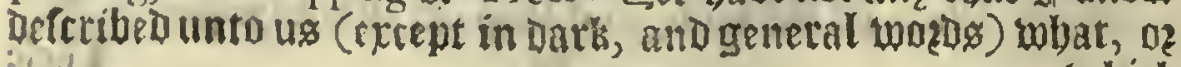
a.1 
wbicb are tbole luperfucus boughs, whicb we mult take atoanj and that is the mode chief, and mod nexiful point to be known in lopping. Gnd twe inap well affuce our felves (as in all orber Arts, to in tbig) there is a bantage, and derterity bn Rill; an bas bit bp pzadice out of experience, in tbe perfozmance bereof, foz the pzofit of mankind : Het do II not knntw (let me lpeak it wotb patiente of our sumning Arborifts) any thing thitbin the tompatsaf bumane affair. toneceftarp, and fo little regarded; nat onlp in Orchards, but alfo in all otber Timber-trees, where, oz wbattoebrr.

Now to our purpofe:

botm manp Forefts, and Woods, wherein you hall bate foz one libelp theibing Tree, four (nap lantetimes twintp four) cbil thzibing, ratten and oping. (Tres, eben tobiles tbey libe; and inftead of Tress, thoufands of bufhes and fhrubs? twat rot= tenels? mbat bollownels? wbat oeas arms? witber'u tops? curtail' 0 trunks ? what loadg of Moffe? Dzouping bugbs: and oping bzancbes thall pou fxe eberp wober? and tbote tbat like in this fozt are in a manner all unprofitabie bougbox canker'd arms, traoked, lítile and thost boals. Tutbat an infinite number of buffes, thzubs, ànd theagso of Hafels, Thornes and

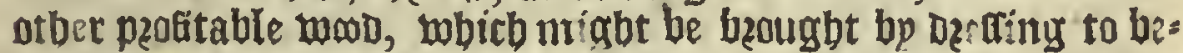
come great, and groolp tráx?

The lefer Wood baty bán (poil'd with carelets, unstillul, and untimely ftowing; and much alto of the geat Wood. ebe greater erese at the fiea riting babe fill'o and obertaden themflibes witb a number of waftefull boughs and fuckers, whicb babe not only dzaton th: fap from tbe boal, but alca batse indor it knottp. and themr to? and the baal moffie, foz toant of De cring; whiceas, if in the peime of growth they bad bán tas ben aman clofe, all but one top, and clean bp tbe bulk, tbe ftrength of all tue fap thou?'s bate gone to the bulk, and fo be worid babe retoberes, and caber'b bís knots, ano babe put

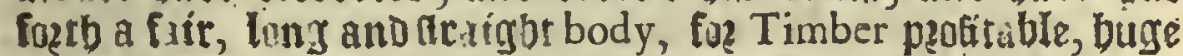
great of surk, and of infinite latt.

It a!l Timber-trees were furb (will fome lap) boto topuld we babe crooked moon fo? Wheels, Coorbs, \&ce?

Anfw. Dzefx all pou tán, anotbere will be enougb crooked fogth. \{e ules.

89028 tben tbis; in mad plates tbey nrotm fo thick, toat nei= tber tbemfelbes, no? eartb. noz anp tbins under oe nex tbem cant thzibe; nnz Sun, nuz Rain, noz Air can Do them, noz anp. tbing nexr, oz unDer them, anp pzotit oz comefnzt.

If tee a number of Hags, wobere our of on? rme pau fotl the

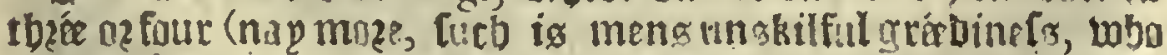
Defiring imany, babz none geod) prettp Oaks, at Athes, thatght and tall; beraute the rot at the fira ibor gibes tapamrin: but if one only of thrm migbe be fuffer'y to geoto, and rbat well, and cleanlp pzun $a$, all to bis berp top, wbat a Tree boulu toe 


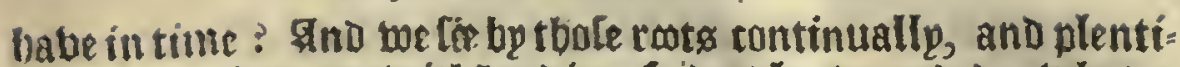
fully fpzinging, notwitbeanding fo Deadly wounded, wbat a commodity thauld arife to the Dwner, and the Commonwealth

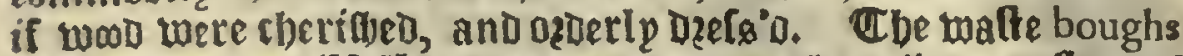
clofelp, and skilfullp taken awap, would gibe us ffoze of Fences, ano Fuel; and the bulk of the Tree in time would nrow of buge lengtb and bignefo: w wat bere (metbinks) 3 bear an unskil ful Arborift fap, that Trexes babe theír feberal forms, eben by nature; the Pear, the Holly, the Afpe, \&c. grotn long in bulk, witb feto and little armes. Ube Oak bp nature bzoad, and lucb like. Gll tbigs 3 grant: 2 sut grant me allo, tbat tbete iss a profitable eni and ufe of ebery Tree, from which if it Decline (tbougb by Nature) pet Man by Art may (nap mua) colted it. \$20tw orber eno of Trees $\$$ neber could learn, tban goo Timber, Fruit mutb and good, and pleafure : afe Phyfical binder natbing a gaod fozm.

Peitber let anp Man eber fo murb as think, that it is unpza: uable, musbllels unpofsible, to refogm any Tree of lobat kind foeber: Foz (beliebe me) 1 babe tried it : I ean bzíng any Tree (beginning up time) to any form. Cbe Pear, and Holly map be made fpread, and the Oak to clofe.

Thus far the good Man out of his eight and forty years experience concerning Timber-trees: He defcends then to the Orchards; which becaufe it may likewife be acceptable to our induftrious. Planter, I thus contract.

6. Such as ftand for Fruits hould be parted from within txo foot (or thereabouts) of the earth; fo high, as to give liberty to drefs the Root, and no higher; becaufe of exhaufting the fap that Thould feed his Fruit : For the boal will be firft, and beft ferved and fed, being next to the root, and of greateft fubftance. There Thould be parted into two, three, or four Arms, as your graffs yield twigs; and every $\mathrm{Arm}$ into two, or more Branches, every Branch into his feveral cyons : ftill fprending by equal degrees; fo as his lowest fpray be hardly without the reach of a mans band, and his highest not paft two yards higher: That no twig (efpecially in the middeft) touch his fellow; let him fpread as far as his lift without any mafter-bough, or top, equally; and when any fall lower then his fellows (as they will with weight of Frrit) eafe him the next/pring of his fuperfluous twigs, and he will rife: When any amount above the reft, top him with a nip between your fingers, or with a knife: Thus reform any cyon; and, as your Tree grows in ftature, and frength, to let him rile with his tops, but flowly, and early; cfpecially in the middeft, and equally in breadth alfo; following him upward, with lopping his under-growth, and water-boughs, keeping the fame diftance of two yards, not above three, in any wile, betwixt the loweft and highelt twigs.

I. Thus thall you bave handfome, clear, healthful, great and lafting Trees. 


\section{A Difcourfe of Foreft-Trees.}

fpreading.

2. Thus will they grow fafe from Winds; yet the top

3. Thus thall they bear much Fruit; I dare fay, one as much as five of your common Trees, all his branchesloaden.

4. Thus thall your Boal being low defraid the branches but little of their fap.

5. Thus thall your Trees: be eafic to $d r e \beta$, and as eafie to gather the Fruit from, without bruifing the Cyons, Ouc $_{\text {. }}$

6. The fitteft time of the Moon for Pruning is (as of Graffing) when the fap is ready to ftir (not proudly firring) and fo to cover the wound. Old Trees would be prun'd before young Plants : And note, that wherefoever you take any thing away, the fap the next summer.will be putting: be fure therefore when he puts to bud in any unfit place, you rub it off with your finger : Thus begin timely with your Trees, and you may bring them to what - form you pleafe. If you defire any Tree fhould be taller, let him break, or divide higher: This for young Trees: The old are reformed by curing of their difeafes, of which we have already difcours'd. There is this only to be confider'd, in reference to Foresters, out of what he has fpoken concerning Fruit-trees; that where Trees are planted for thadow, and meer ornament, as in Walks, and Avenues, the Brome-mood (as they call it) fhould molt of it be cherifhed; whereas in Fruit, and Timber-trees.(Oak excepted) it is belt to free them of it: As for Pollards (to which I am no great friend becaufe it makes fo many friags and dmarfes of many Trees which would elfe be good Timber; endangering them with drips and the like injuries) they fhould not be beaded above once in ten or twelve years, at the beginning of the fpring, or end of the Fall.

7. For the improvement of the fpeedy growth of Trees, there is not a more excellent thing then the frequent rubbing of the Boalor stem, with fome piece of bair-clotb, or ruder ftuff, at the beginning of spring : fome I have known done with Seales-skin; the more rugged bark with a piece of Coat of Maile, which is made of fmall myres; thisdone, when the body of the Trees are wet, as after a foaking Rain; yet fo, as not to excorticate, or gall the Tree, has exceedingly accelerated its growth, by opening the pores; freeing them of mols, and killing the worm.

8. Laftly, Frondation, or the taking off fome of the luxuriant branches, and fprays, of fuch Trees, efpecially whofe leaves are profitable for Cattel (whereof already) is a kind of prinning : and fo is the fcarifying, and crofs hatching of fome Fruit-bearers, and others, to abate that evrsouxice which fpends all the juice in the leaves to the prejudice of the reft of the parts.

9. This, and the like, belonging to the care of the Wood-20ards will mind him of his continual duty; which is to walk about, and furvey his young Plantations daily; and to fee that all Gaps be immediately ftopp'd; trefpafling Cattle impounded; and (where they are infefted) the Deer chafed out, doc. It is moft certain that Trees preferv'd, and govern'd by this difcipline, and according to 
the Rules mention'd, would increafe the beauty of, Forests, and value of Timber, more in ten, or twelve years, then all other imaginable Plantations (accompanicd with our ufun! nerglect) can do in forty or fifty:

10. To conclude, in the time of this Work would our ingenious Arborator frequently. incorporate, mingle, and unite the Arms and Branches of fome young and flexible Trees which grow in confort, and neer to one another; by entering them into their mutual barks with a convenient infition: This, efpecially, about Fields, and Hedge-rows for Fénce and ornanzent; alfo by bowing, and bending of others, efpecially $O a k$ and $A f h_{5}$, into varions flexures, curbs and poftures, oblig'd to ply themfelves into difierent Modes, which may be done by humbling and binding them down with tough bands and withs, till the tenor of the $\int a p$, and cuftom of being fo conftrain'd, did render them apt to grow fo of themfelves, without power of redreffing; This courfe would wonderfully accommodate Materials for Knee-timber and shipping, the wibelwright and other ufes; conform it to their Moulds, and lave infinite labour, and abbreviate the work of hewing and wafie,

\section{- adeo in teneris coñfuefcere mulium est.}

the poet, it feems, knew it well, and for what purpoles,

Continuò in Sylvis magna vi flexa domatur

In burim, curvi formam accipit vlmus aratri: Geo.r.

fo as it even half made the Plows to their hands.

\section{CHAP. XXIX.}

\section{of the Age, Stature, and Felling of Trees.}

Felling.

I. T is not till a Tree is arriv'd to his perfect Age, and full vigor, that the Lord of the Forest fhould confult, or decermine concerning a Felling. For there is certainly in Trees (as in all things elfe) a time of Increment, or growth; a status or fealon when they are at best (which is alfo that of Felling) and a decrement or period when they decay.

To the firtt of thefe they proceed wirh more, or lefs velocity, as they confift of more ftrict and compacted particles, or are of .a lighter, and more laxed contexture; by which rhey receive a fpeedier, or flower definxion of Aliment: This is apparent in Box, and Willow; the one of a harder, the other of a more tender fubstance: But as they proceed, fo they, likewife continue.

By the flate of Trees I would fignific their utmoft effort, growth, and 


\section{A Difcourse of Foreft-Trees.}

and maturity, which are all of them different as to time, and kind; yet do not I intend by this any period or inftant in which they do not continually either Improve or Decay (the end of one being ftill the beginning of the other) but farther then which their $\mathrm{Na}$ tures do not extend; but immediately (though to our fenfes imper. ceptibly) through fome infirmity (to which all things fublunary be obnoxious) dwindle and impair, either through Age, defect of Nouriflument, by ficknefs, and decay of principal parts; but efpecially, and more inevitably, when violently invaded by mortal and incurable Infirmities, or by what other extinction of their native beat, Jubftrvition, or obstrustion of Air and Moisture, which making all motions whatfoever to ceafe and determine, is the caufe of their final deftruction.

2. Our honeft Countrey-man, to whofe Experience we have been obliged for fomething I have lately Animadverted concerning the Pruning of Trees, does in another chapter of the fame Treatife fpeak of the Age of Trees. The Difcourfe is both learned, rational, and full of encouragement: For he does not fcruple to affirm, That even fome Fruit-Trees may poffibly arrive to a thoufand years of Age; and if fo Fruit-Trees whofe continual bearing does fo much impair and fhorten their lives, as we fee it does their form and beauty; How much longer might we reafonably imagine fome hardy and flow-growing Forcft-trees may probably laft? I remember Pliny tells us of fome Oaks. growing in his time in the Hercynian. Foreft, which were thought co-evous with the World it felf; their roots had even raifed Mountains, and where they encounter'd fwell'd into goodly Arckes like the Gates of a City: But to our more modern Author's calculation for Fruit-trees (I fuppofe he means Pears, Apples, \& c.) his allowance is three handred years for. growth, as much for their ftand (as he terms it), and three hundred for their Decay, which does in the total amount to no lefs then nine bundred years. This conjecture is deduc'd from Apple-Trees growing in his orcbard, which having known for fourty years, and upon diligent enquiry of fundry aged Perfons of eighty ycars and more, who remembred them Trees all their time, he finds by comparing their growth with others of that kind, to be far fhort in bignels and perfection; (viz. by more then two parts of three) yea albeit thofe other Trees have been much hindred in their frature through ill government and ordering. .

3. To eftablith this he affembles many Arguncnts from the age of Animals, whofe ftate and decay double the time of their increafe by the faine proportion: If then (faith he) thofe frail Creatures, whofe bodies are notbing (in a manner) but a tender rottennefs, may live to that age, I fee not but a Trce of a folid fubftance, not damnified by heat or cold, capable of and fullject to any kind of ordering or dreffing, feeding naturally, and front the beginning disburthen'd of all juperguities, eafed of, and of bis own accord avoiding the camfes that may annoy bim, frould double the life of ot ber Creatures by very many years. Hic procecds, What elfe are Trees in comparijon with the Earth, but as hairs to the body of Man? And it is certain, 
that (without fowe diftemper, or forcible canfe) the hairs dire with the body, and are eftecm'd cxcrements but from their fuperfinows growtb: So as he refolves upon good Reafon, that Fruit-trees well ordered may live a thoufand years, and bear Fruit, and the longer the more, the greater, and the better (for which an Inftunce alfo in Mr Beale's Hereford-foire Orchards, pag.2 1,22.) becaufe his vigour is proted and fronger, when his years are many. Thus thall you fec old Irees put forth their Buds and Blofomes both fooner and more plentifully then young Trees by much; And I fenfibly perceive (faith he) my young Trees to enlarge their Fruit as they grow great$e r$, duc. And if Fruit-Trees continue to this Age, how many Ages is it to be fuppofed ftrong and huge Timber-trees will laft? Whofe inaffie bodies require the years of divers Metbufala's before they determine their days; whofe $S$ ap is ftrong and bitter; whofe Bark is hard and thick, and their fubftance folid and ftiff; all which are defences of health and long life. Their ftrength withftands all forceable Winds; their Sap of that quality is not fubject to Worms and tainting; their Bark receives feldome or never by cafualty any wound; and not only fo, but he is free from Removals, which are the death of millions of Trees; whereas the Fruit-tree (in comparifon) is little, and frequently blown down; his sap fweet, eafly and foon tainted; his Bark tender, and foon wounded; and himfelf ufed by Man as Man ufes himfelf; that is, either unskilfully, or carelejly. Thus he.

4. I might to this add much more, and truly with fufficient probability, that the Age of Timber-trees, efpecially. of fuch as be of a compact, refinows, or balfamical nature (for of this kind are the Eugh, Box, Horn-bean, White-thorn, Oak, Walnut, Cedar, Funiper, $\mathcal{C u}_{\mathrm{c} .)}$ are capable of very long duration and continuance: thofe of largeft Roots, longer liv'd then the fhorter; the dry, then the wet; and the gummy, then the watry: For not to conclude from Pliny's Hercynian Oaks, or the Terpentine Tree of Idum\&a, which Jofepbus rankes alfo with the Creation; I read of a Cypreß yet remaining fome where in Perfia neer an old sepulchre, whofe ftem is as large as five men can encompals, the boughs extending fifteen paces every way; This muft needs be a very old Tree, believ'd by my Autbor little lefs then 2500 years of age: The particulars were too long to recount. The old Platanus fet by Agamemnon, and the Herculean Oaks, the Laurel neer Hippocren, the $V$ atican Ilex, and old Lotus Trees, recorded by Valerius Maximus, were famous for their age: St Hierome affirms he faw the sycomore that Zaccheus climb'd up, to fee our LORD ride in Triumph to Fervefalem: And now in the Arentine Mount they thew us the Malus Medica, planted by the hand of Se Dominic: To which add thofe fuperannuated Tilia's now at Bafl, and that of Aupurg, under whofe prodigious frade they fo often feaft, and celebrate their IVeddings; becaufe they are all of them noted for their reverend Antiquity; for to fuch Trees it feems they paid Divine honours, as the neareft Emblems of Eternity, dutanquam facros ex vetuftate, as Quintilian fpeaks: And like to thefe might that be which is 


\section{A Difcourfe of Foreft-Trees.}

celebrated by our Poet, neer to another Monument,

\section{_._-juftáque antiqua cupreffus \\ Relligione patrum multos fervata per annos. En.2.}

5. But we will fpare our Reader, and refer him that has a defire to multiply examples of this kind, to thofe undoubted Records our Naturatist mentions in his $44:$ Chap. Lib. I 6 . where he thall read of Scipio Africanus's Olive-trees; Dianas Lotus; the overgrown Myrtil; the Vatican Holm, thofe of Tybertine, and efpecially, that neer to Tuf culum, whore body was thirty. five foot about; befides divers others which he there enumerates in a large Chapter: And what thall we conjecture of the age of Xerxes's huge Platanus, in admiration whereof he ftaid the march of fo many hundred thoufand men for fo many days : by which the wife socrates was us'd to freear? And certainly, a goodly Tree was a powerful attractive, when that prudent Conful palfrenus. Cripsss fell in love with a prodigious Beech of a wonderful age and ftature.

6. We have already made mention of Tiberius's Larch, and that of the Float which wafted Caligulas obelisks out of Kgypt, four fathoms in circumference : We read alfo of a Cedar growing in the Ifland of Cypris which was 130 foot long, and 18 in diametêr; of the Plane in Athens whofe roots extended 36 Cubits farther then the boughs; which were yet exceedingly large; and fuch another .was that molt famous Tree at Veliternus, whofe arms ftretch'd out 80 foot from the ftem : But thefe were folid: Now if we will calculate from the bollow, befides thofe mention'd by. Pliny in the Hercynian Foreft; the Germans (as now the Indians) had of old fome Punti or Canoes of excavated Oak which would well contain thirty, fome fourty perfons : And the Lician Platanus recorded by the Naturalist, and remaining long after his days, had a room in it of eighty one feet in compafs, adorn'd with Fountains, ftately Seats and Table siof ftone; for it feems it was fo glorions a Tree both in body, and head, that Licinius Mutianus. (three times Conful, and Governour of that Province) us'd to feaft his whole Retinue in it, chufing rather tolodge in it, then in his golden-roofed Palace.

7. Compare me then with the fe that nine-fathom'd deep Tree fpoken of by Fofepbus à Costa; the Mastick-tree - feen and meafur'd by Sir Francis Drake, which was four and thirty yards in circuit; and for prodigious height the two, and three bundredfoot unparallel'd Palnas-royal defcrib'd by Captain Ligon growing in our Plantations of the Barbados; or thore goodly Masts of Fir, which I have feen, and meafur'd, brought from New England; not to omit the vaft, and incredible bulk of fome oaks ftanding lately in Westphalia, whereof one ferv'd both for a Castle and Fort; bécaufe in this refention we will endeavour to give a tafte of more frefl obfervations, and to compare our modern Timber. with the Ancient, and that, not only abroad, but without travelling into forreign Countries for thefe wonders: 
8. What goodly Trees were of old ador'd, and confecrated by the Dryads I leave to conjecture from the ftories of our ancient Britains, who had they left Records of their prodigies in thiskind, would doubtlefs have furnifh'd us with examples as remarkable for the gromtb and ftature of 'Trees, as any which we have deduc'd from the Writers of forreign places, fince the remains of what are yet in being (notwithftanding the havock which has univerfally been made, and the little care to improve our Woods) may ftand in fair competition with any thing that Antiquity can produce.

9. There is fomewhere in Wales an Infcription extant, cut into the wood of an old Beam, thus

\section{SEXAGINTA PEDES FUERANT IN STIPITE NOSTRO, EXCEPTA COMA QUA SPECIOSA FUIT.}

This muft needs have been a noble Tree, but not without later parallels; for to inftance in the feveral pecies, and fpeak firft of the bulks of fome immenfe Trees; there was ftanding an old and decay'd Cheß-nut at Frailing in Efexx, whofe very ftump did yield thirty fizable load of Logs; I could produce you another of the fame kind in Glocesterfoire which contains within the bowels of it a pretty wain-fcotted Room inlighten'd with windows, and furnifh'd with feats, \& $c_{0}$. to anfwer the Lician Platanus lately mention'd.

IO. But whileft I am on this period; fee what a Tilia that moft learn'd, and obliging perfon, D. Brovon of Norwich, defcribes to me in a Letter juft now receiv'd.

An extraordinary large, andftately Tilia, Linden or Lime-tree, there groweth at Depeham in Norfolk, ten miles from Norwich zohofe meafure is this. The compa 3 in the least part of the Trunk or body about two yards from the grownd is at least eight yards and half: about the root night the earth, fixteen yards; about balf a yard above that, neer twelve yards in circuit : The height to the uppermost boughs about thirty yards, which furmounts the famous Tilia of $\mathrm{Zu}-$ rich in Switzerland; and uncertain it is whether in any Tilicetum, or Lime-walk abroad it be confiderably cxceeded: ret was the first motive I had to view it not fo much the largene $\beta$ of the Tree, as the generalopinion that no man could ever name it; but I found it to be a Tilia fæmina; and (if the diftinction of Bauhinus be admitted from the greater, and lefer leaf) a Tilia Platuphyllos or Latifolia; fome leaves beang three inches broad; but to diftinguifs it from otbers in the Country, I call'd it Tilia Coloflæa Depehamenlis. Thus the Doctor.

A Poplar-tree not much inferior to this he informs me grew lately at Harlingly Thetford, at Sir William Garsdies gate, blown down by that terrible Hurrocan about four years fince.

II. I am told of a very Withy-tree to be feen fomewhere in Bark-Sire which is increafed to a moit ftupendious bulk: But theefe for arriving haftily to their Acne, and period, and generally not fo confiderable for their ufe; I pafs to the $A h_{0}$ Elm, Oak, Evc. 
There were of the first of thefe divers which meafur'd in length

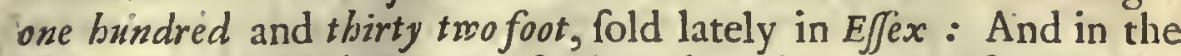
Manor of Hortoiz (to go no farther then the Parifh of Eb/ham in Surrey, belonging to my Brother Richard Evelyn Efq.) there are Elms now ftanding in good numbers, which will bear almoft three - foot fquare for more then forty foot in height, which is (in my judgement) a very extraordinary matter.: They grow in a moift Gravel, and in the Hedge-rows.

Not to infift upon Beech, which are frequently very large; there are Oaks of forty foot high; and five foot diameter yet flourilhing in divers old Parks of our Nobility and Gentry.

A large and goodly Oakthere is at Reedham in Sir Richard Berneys Park of Norfolk, which I am inform'd was valu'd at forty pounds the Timber, and twelve pounds the lopping wood.

12. Nor are we to over-pafs thofe memorable Trees which fo lately flourithed in Dennington Park neer Newberry : amongft which three were inoft remarkable from the ingenious Planter, and dedication (if Tradition hold) the famous Englifh Bard, Feofry Claucer; of which one was call'd the K-ings, another the Queens, and a third chaucers-Oak. The first of thefe was fifty foot in height before any bough or knot appear'd, and cut five foot fquare at the butt end; all clear Timber. The Queens was fell'd fince the - Wars, and held forty foot excellent Timber, ftraight as an arrow in growth and grain; and cutting four foot at the $j t u b$, and neer $a$ yard at the top; befides a fork of almoft ten foot clear timber above the thaft, which was crown'd with a fbady tuft of boughs; amongft which, fome were on each fide curved like Rams-borns, as if they had been fo induftriounly bent by hand. This oak was of a kind fo excellent, cutting a grain clear as any clap-board (as appear'd in the Wainfcot which was made thereof) that a thoufand pities it is fome feminary of the Acorns had not been propagated, to preferve the fpecies. Chancers oak, though it were not of thefe dimenfions, yet was it a very goodly Tree: And this account I receiv'd from my moft honour'd friend Pbil. Packer Efq: whofe Father (as now the Gentleman his Brotber) was proprietor of this Park: But that which I would farther remark, upon this occafion, is, the bulk, and $f$ tature to which an Oak may poffibly arrive within lefs then two bundred year, fince it is not fo long that our Poet flourifh'd (being in the Reign of King Edibard the fourth) if at leaft he were indeed the Planter of thole Trees, as 'tis confidentiy affirm'd. I will not labour much in this enquiry; becaufe an implicit faith is here of great encouragement; and it is not to be conceiv'd what Trees of a gcodkind, and apt foil, will perform in a few years; and this (I am inform'd) is a fort of gravelly clay moiftn'd with finall and frequent fprings.

13. There was in Cuns-burrow (fometimes belonging to my Lord of Dpver) (everal Trees bought of a Couper, of which he made ten pound per yard' for three or four yards, as I have been' credibly affur'd: But where thall we parallel that nighty Tree which furnilh'd the Main-mast to the Sovereign of our Seas, which 
being one hundred foot long fave one, bare thirty five inches diameter. Yet was this exceeded in proportion, and ufe, by that Oak which furnifh'd thofe prodigious beanis that lye thwart her. The diameter of this Tree was four foot nine inches, which yielded four-fquare beams of four and forty foot, long each of them. The onk grew about Framingam in suffolk; and indeed it would be thought fabulous, but to recount only the extraordinary dimenfions of fome Timber-trees growing in that County; and of theexceffive fizes of thefe materials, had not mine own hands meafur'd a Table (more then once) of above fize foot in breadth, wine and an balf in length, and $f(x)$ inches thick, all intire and clear : This plank cuit out of a Tree fell'd down by my Fathers order, was made a Paftry-board, and lyes now on a frame of folid Brick-mork at Wolton in surrey, where it was fo placed before the room was finih'd about it, or wall built, and yet abated by one foot thorter, to confine it to the intended dimenfions of the place : for at firft, it held this breadth, full ten foot and an balf in length.

14. To there I might add that fuprannuated Eugh-tree growing now in Braburne Church-yard, not far from scots-ball in Kent; which being 58 foot 1 I inches in the circumference, will bear neer twenty foot diameter, as it was meafur'd firlt by my felf imperfectly, and then more exactly for me, by order of the Right Honourable Sir George Carteret, Vice-Chamberlain to his Majefty, and Treafurer of the Navy : not to mention the goodly planks, and other confiderable pieces of fquar'd, and clear Timber, which I obferv'd to lye about it, that had been bew'd, and fann out of fome of the Arms only, torn from it by impetuous winds. Strch another Monster I am inform'd is alfo to be feen in Sutton Church:yard neer Winchester : But thefe (with infinite others, which I am ready to produce) might fairly fuffice to vindicate, and affert our Propofition, as it relates to modern examples, and fizes of Timbertrees, comparable to any of the Ancients, remaining upon laudable and unfufpected Record; were it not great ingratitude to conceal a moft induftrious, and no lefs accurate Accompt, which comes jult now to my hands from $\mathrm{M}^{\mathrm{r}}$. Halton, Auditor to the Right Honourable, the moft Illuftrious, and Noble, Henry Howard of Norfolk.

\section{In Sheffield Lordfoip.}

The names of 15 . In the Hall Park, neer unto Rivelin, ftood an Oak which had she perfons eighteen yards without bough, or knot; and carried a yard and telligenee of $\int i x$ inches fquare at the faid height, or length, and not much bigthe particu- ger neer the root: Sold twelve years ago for I I li. Confider the lars. diftance of the place, and Country, and what fo prodigious a Tree Ed.Rawfon. would bave been worth neer London.

In Firtb's Farme within sheffield Lordfip, about twenty years fince, a Tree blown down by the wind, made or would have made two Forge-hammer-beans, and in thofe, and the other wood of that Tree, there was of worth,or made 50 li. and Godfrey Frogat (who is now 
now living ) did oft fay, he loft $30 \mathrm{li}$. by the not buying of it.

A Hammer-beam is not lefs then $7 \frac{1}{2}$ yards long, and 4 foot fquare at the barrel.

In sbeffield Park, below the Manor, a Tree was ftanding which was fold by one Giffard (fervant to the then Counte乃 of Kent) for $2 l i .10$ s. to one Nich. Hicks; which yielded of fawn Wair four-: teen hundred, and by eftimation, twenty chords of wood:

A Wair is two yards long, and one foot broad, fixfcore Ed. Morphy to the hundred : fo that, in the faid Tree was 10080 Wood-ward: foot of Boards; " which, if any of the faid Boards were more then balf-inch thick, renders the thing yet more admirable.

In the upper end of Rivelin ftood a Tree, call'd the Lords-Oak, of twelve yards about, and the top yielded twenty one Chord, cut down about thirteen years fince.

In s beffield Park. An. I646. Atood above roo Trees worth rooo li: and there are yet two worth above $20 \mathrm{li}$. fill note the place, and market.

In the fame Park, about eight years ago, Ralph Archdall cut a. Tree that was thirteen foot diameter at the Kerf, or cutting place neer the Root.

In the fame Park two years fince Mr. Sittwell, with Jo. Mag for did chufe a Tree, which after it was cut, and laid afide flat upon a level ground, Sam. Staniforth a Keeper, and Ed. Morphy, both on. horfe-back, could not fee over the Tree one anothers Hat-cromns. This Tree was afterwards fold for $20 \mathrm{li}$.

In the lame Park, neer the old foord, is an Oak-tree yet ftanding, of ten yards circumference.

In the fame Park, below the Conduit Plain, is an Oak-tree which Jo,Halton, bears a top, whofe boughs thoot from the boal fome fifteen, and fome fixteen yards.

Then admitting $15^{\frac{x}{3}}$ yards for the common, or mean extent of the boughs from the boal, which being doubled is 31 yards; and if it be imagin'd for a diameter, becaufe the Ratio of the diameter to the circunference is $\frac{113}{355}$ it follows $113.355:: 31.97 \frac{44}{113}$ jards. which is the circumference belonging to this diameter.

Then farther it is demonftrable in Geometry, that half the diameter multiplied into half the circumference produces the Area or quantity of the Circle, and that will be found to be $754 \frac{347}{45}$ which is 755 fquare yards ferè.

Then laftly, if a Horfe can be limited to three fquare yards of ground to ftand on (which may feem a competent proportion of three yards long, and one yard broad) then may 25 I Horfe be well faid to ftand under the thade of this Tree. But of Scotch Cattle certainly, more then twice that number. 


\section{Workfopp-Park.}

16. In this Park, at the corner of the Bradfhaw-rail, lyeth the boal of an Oak-tree which is twenty nine foot about; and would Kenhelm be found thirty, if it could be juftly inealur'd; becaufe it iyer's Homer. is. upon the ground; and the length of this boal is ten foot, and no arm, nor branch upon it.

In the fame Park, at the white-gate, a Tree did ftand that was

Jo.Magron. Geo. Hall. from bough end to bough end (that is, from the extream ends of two oppofite boughs) 180 foot; which is witnefs'd by fo.Magfor and Geo. Hall, and meafur'd by them both.

Then becaufe 180 foot, or 60 yards is the diameter; 30 - yards will be the femidiameter : And by the former. Analogies

$$
\begin{gathered}
\text { I13. } 355:: 60.188 \frac{1}{x} \\
\text { and } \\
\text { I. } 30:: 94^{\frac{1}{4}} \cdot 2827^{\frac{1}{2}}
\end{gathered}
$$

That is, the content of ground upon which this Tree perpendicularly drops, is above 2827 fquare yards, which is above half an Acre of ground: And the affigning three fquare yards (as above) for an Horfe, there may 942 be well faid to ftand in this compafs.

In the fame $P$ ark (after many hundreds fold, and carried away)

Jo.Magfon. there is a Tree which did yield quarter-cliff bottoms that were a, yard fquare : and there is of them to be leen in worksopp, at this day, and fome Tables made of the faid quarter-cliff likewife.

In the fame 'Park, in the place there call'd the Hawks-nest, are Tree forty foot long of Timber which will bear two foot fquare at the top-end or height of forty foot.

If then a fquare whofe fide is two foot, be infcribed in a Circle, the proportions at that Circle are

$\begin{array}{lc} & f e e t \\ \text { Diameter } & 2: 8284 \\ \text { Circumference } & 8: 8858 \\ \text { Area } & 6: 283 \mathrm{I}\end{array}$

And becaufe a Tun of Timber is faid to contain forty folid' feet : one of thefe Columns of Oak will contain above fix Tun of Timber and a quarter : in this computation taking them to be Cylinders, and not tapering like the fegment of a Cone.

\section{Welbeek-Lane.}

17. The Oak which fands in this Lane call'd Grindal-Oakhath at thefe feveral diftances from the ground thefe circumiferences

$\begin{array}{ll}\text { foot } & \text { foot inch } \\ \text { at } 1 & 33: 01 \\ \text { at } 2 & 28: 05 \\ \text { at } 6 & 25: 07\end{array}$

The breadth is from bough-end to bough-end $(i$.$) diametri-$ 
cally 88 foot; the height from the ground to the top-moft bough 8 I foot [this dimenfion taken from the proportion that a Gnomor bears to the fhadow] there are three Arms broken off and gone, and eight very large ones yet remaining, which are very frefh and good Timber.

88 foot is $29 \frac{\pi}{3}$ yards, which being in this cafe admitted for the diameter of a circle, the fquare yards in that circumference, will be 676 fere ; and then allowing three yards (as before) for a beaft, leaves 225 bealts, which may poffibly ftand under this Tree.

But the Lords-Oak that ftood in Rivelin was in diameter three yards, and twenty eight inches; and exceeded this in circumference three feet at one foot from the ground.

\section{Shire-Oak.}

Sbire-Oak is a Tree ftanding in the ground late Sir Tho. Hewets, about a mile from Worksopp-Park, which drops into three shires, viz. Tork, Nottingham, and Derby, and the diftance from boughend to bough-end is ninety foot and thirty yards."

This circumference will contain neer $70>$ fquare-yards, fufficient to thade 235 borfe.

Thus for the accurate M. Halton.

18. Being inform'd by a perfon of credit, that an Oak in Shef field-Park, call'd the Ladies $-0 n k$, fell'd, contain'd forty two Tun of Timber, which had Arms that held at leaft four foot fquare for ten yards in length; the Body fix foot of clear Timber: That in the fame Park one might have cholen above Iooo Trees worth above

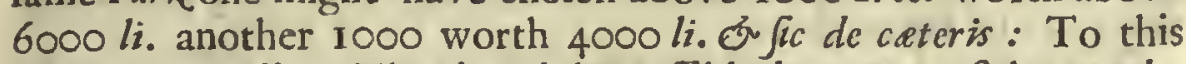
M. Halton' replies, That it might poffibly be meant of the LordsOakalready mention'd to have grown in Rivelin: For now Rives lin it felf is totally deftitute of that iffue the once might have glo ried in of Oaks; there being only the Hall-park adjoyning which keeps up with its number of 0 aks. And as to the computation of 1000 Trees formerly in Sheffield-Park, worth $6000 \mathrm{li}$. it is believ ${ }^{\circ} \mathrm{d}$ there were a thoufand much above that value; fince in what is now inclos'd, it is evident touching 100 , worth a thoufand pounds.

My worthy friend Leonard Pinckney Efq. firft Clerk of his Majefties Kitchin (from whom I receiv'd the firft hints of many of thefe particulars) did aflure me, that one John Garland built a very handfome Barne containing five Baies, with $\boldsymbol{P}$ an, Posts, Beams, spars, \&c. of one fale Tree growing in Worksop-park. But thefe fhall fuffice, I thould never finin to purfue thefe Inst ances through our once goodly Magazines of Timber for all ules, growing in this our native Country, comparabie (as I faid) to any we cart produce of elder times; and that not only (though chiefly) for the cncouragement of Planters, and Prefervers of one of the molt excellent, and neceffary Materials in the World for the benefit of Man; but to evince the continu'd vigor of Nature, and to reproach the 
want of Industry in this Age of ours; and (that we may return to the Argament of this large Chapter) to affert the procerity and ftature of Trees from their very great Antiquity: For certainly if that be true, which is by divers affirmed concerning the $\mathscr{2}$ uercetum of Mambre, recorded'by Eufebius to have continued till the time of conftantine the Great, we are not too prejudicately to cenfure what has been produc'd for the proofs of their Antiquity; nor for my part do I much queftion the Authorities: But let this finffice; what has been produc'd bcing only' an hiftorical peculation, of more encouragement haply then other ufe, but fuch as was pertinent to the fubject under confideration, as well as what I am about to add concerning the Texture and Jimilar parts of the body of Trees, which may alto hold in forubs, and other lignous plants, becaufe it is both a curious and Rational account of their Anatomization, and worthy of the fagacious. Inquiry of that incomparably learned Perfon DrGoddard, as I find it entered amongft other of thofe precious Collections of this rlluftrious Society.

19. The Trunk, or bough of a Tree being cut tranfverfely plain and fmooth, Theweth feveral Circles or Rings more of lefs Orbicular, according to the external figure, in fome parallel proportion, onc without the other, from the centre of the Wood to the infide of the Bark, dividing the whole into fo many' circular fpaces. Thefe Rings are more large, grofs, and diftinct in colour and fubftance in fome kind of Trees, generally in fuch as grow to a great bulk in a fhort time, as Fir, Afh;\&c. fmaller or lefs diftinct in thofe that either not at all or in a longer time grow great, as 2 uince, Holly, Box, Lignum-vita, Ebony, and the like fad colour'd and hard moods; fo that by the largenefs or fmallnefs of the Rings, the quicknefs or flownefs of the growth of any Trce may perhaps at certainty be eftimated.

Thefe paces are manifeftly broader on the out fide then on the other, efpecially the more outer, to a double proportion, or more; the inner being neer an equality.

It is afferted, that the larger parts of thefe Rings are on the South and funny fide of the Tree (which is very rational and probable) infomuch that by cutting a Tree tranfverfe, and drawing a diametre through the broadeft and narroweft parts of the Rings, a Meridian line may be defcribed.

The outer fpaces are generally narrower then the inner, not only on their narrower fides, but alfo on their broader, compared with the fame fides of the inner; Notwithftanding which, they are for the moft part, if not altogether, bigger upon the whole account.

Of thefe fpaces, the outer extremities in Fir, and the like woods, that have them larger and grofler, are more denfe, hard, and compace; the inner more foft and fpungy; by which difference of fubftance it is that the Rings themfelves come to be diftinguifhed.

According as the bodies and boughs of Trees, or feveral parts of the fame, are bigger or leffer, fo is the number as well as the breadth of the circular fpaces greater or lefs; and the like according to the age,efpecially the number. 
It is commonly and very probably afferted, That a Tree gains a new one every year. In the body of a great Oak in the New-Forest, cut tranfverfly even (where many of the Trees are accounted to be fome hundreds of years old) three and four hundred have been diftinguifh'd. In a Fir-tree, which is faid to have juft fo many rows of boughs about it as it is of years growth, there has been obferved juft one lefs immediately above one row, then immediately below: Hence fome probable account may begiven of the difference between the outer and the inner parts of the Rings; that the outermoft being newly produced in the Summer, the exterior fuperficies is condens'd in the Winter.

20. In the young branches and twigs of Trees there is a pith in the middle, which in fome, as $A / h$, and efpecially Elcler, equals or exceeds in dinienfions the reft of the fubftance, but waxes lefs as they grow bigger, and in the great boughs and trunk farce is to be found: This gives way for the growth of the inward Rings, which at firft were lefs then the outer (as may be feen in any fhoot of the firft year) and after grow thicker, being it felf abfum' $d$, or perhaps converted into Wood; as it is certain Cartilages or Gristles are into bones (in the bodies of Animals) from which to fenfe they differ even as much as pith from Wood.

Thefe Rings or fpaces appearing upon tranfverfe Section (as they appear elliptical upon oblique, and ftrait lines upon direct Section) are no other then the extremities of fo many Integuments invefting the whole Tree, and (perhaps) all the boughs that are of the fame age with any of them, or older.

In the gromth of Trees Angmentation in all dimenfions is acquired, not only by Acce/fion of a new Integument yearly, but alfo by the Reception of nourifhment into the Pores, and fubftance of the reft, upon which they alfo become thicker; not only thofe towards the middle, but alfo the reft, in a thriving Tree: Yet the principal growth is between the Bark and Body, by Acce/Jion of a new Integument yearly, as hath been mentioned: Whence the cutting of the Bark of any Tree or Bough round about will certainly kill it.

The Bark, of a Tree is diftinguifhed into Rings or Integuments no lefs then the Wood, though much finaller or thinner, and therefore not diftinguifhable except in the thick barks of great old Trees, and toward the infide next the Wood; the outer parts drying and breaking with innumerable fifures, growing wider and deeper, as the body of the Tree grows bigger, and mouldering away on the out fide.

Though it cannot appear by reafon of the continual decay of it upon the account aforefaid; yet it is probable the Bark of a Tree hath had fuccellively as many Integuments as the mood; and that it doth grow by acquifition of a new one yearly on the infide, as the wood doth on the out-fide; fo that the chief way, and conveyance of nourifhment to both the Wood and the Bark, is between them both.

The leaft Bud appearing on the body of a Tree doth as it 
were make perforation through the feveral Integuments to the middle, or very neer; which part is, as it were, a root of the boing into the body of the Tree; and after becomes a knot; more hard then the other mood: And when it is larger, manifently thewing it felf alfo to confift of feveral Integuments, by the circles appearing in it, as in the body : more hard, probably; becaufe ftreightned in room for growth; as appears by its diftending, buckling, as it were, the Integuments of the wood about it; fo implicating them the more; whence a knotty piece of roodis fo much harder to cleave.

It is probable, that a Cience or Bud, upon Graffing, or Inoculating, doth, as it were, Root it felf into the ftock in the fame manner as the branches, by producing a kind of knot. Thus far the accurate Doctor.

20. To this might be fubjoyn'd the vegetative motion of Plants, with the diagrams of the Fefuite Kercher, where he difcourfes of their fupendious Magnetifins, \&uc. could there any thing material be added to what has already been fo ingenioufly inquir'd into : therefore let us proceed to their Felling.

2 I. It thould be in this $f$ tatus, vigour and perfection of Trees, that a Felling thould be celebrated; fince whiles our Woods are growing it is pity, and indeed too foon; and when they are decaying, too late: Ido not pretend that a man (who has occalion for Timber) is obliged to attend fo many ages ere he fell his Trees; but I do by this infer, how highly neceflary it were, that men fhould perpetually be planting; that fo posterity might have Trees fit for their fervice of competent, that is, of a middle growth and age, which it is impoffible they fhould have, if we thus continue to deftroy our Woods, without this providential planting in their ftead, and felling what we do cut down, with great difcretion, and regard of the future.

22. Such therefore as we thall perceive to decay are firft to be picked out for the $A x$; and then thofe which are in their ftate, or approaching to it; but the very thriving, and manifently improving, indulg'd as much as poffible.

23. The time of the year for this deftructive work is not ufually till about the end of April (at which feafon the bark does commonly rife freely) though the opinions and practice of men have been very different: Vitruvius is for an Autumnal F all; others advife December and Fainuary: Cato was of opinion Trees thould have firtt born their Fruit, or, at leaft, not till full ripe, which agrees with that of the Architect: And though Timber unbarked be indeed more obnoxious to the $W$ orm, and to contract fornewhat a darker hue (which is the reafon fo many have commended the feafon when it will moft freely ftrip) yet were this to be rather confider'd for fuch Trees as one would leave round, and unfquar'd; fince we finde the wilde $0 a k$, and many other forts, fell'd over late, and when the fap begins to grow proud, to be very fubject to the morm; whereas being cut about mid-winter it neither cafts, rifts, nor tmines; becaufe the cold of the minter does 
both dry, and confolidate; whiles in $\beta$ ring, and when pregnant, fo much of the virtue goes into the leaves and branches: Happy therefore were it for our Timber, fome real Invention of Tanning without fo much Bark'(as the Honourable $\mathrm{M}^{\mathrm{r}}$ Charles Howsard has moft ingenioully offer'd) were become univerfal, that Trees being more early fell'd, the Timber might be better 'Feafor'd and condition'd for its various $v \int e s$. But as the cuftom is, men have now time to fell their moods, even from mid-winter to the pring; but never any after the Summer Solftice.

24. Then for the Age of the Moon, it has religioully been obferv'd; and that Dianos prefidency in sylvis was not fo much celebrated to credit the fictions of the Poets; as for the dominion of that moif Planet, and her influence over Timber: For my part, I am not fo much inclin'd to thefe Criticifms, that I fhould altogether govern a Felling at the plcafure of this mutable Lady; however there is doubtlefs fome regard to be had,

\section{. Necfrustra fignorum obitus ßeculaimur or ortus.}

The old Rules are thefe:

Fell in the decreafe, or four days after conjunition of the two great Luminaries; fome the laft quarter.of it; or (as.Pliny) in the very article of the change, if polfible; which hapning (faith he) in the laft day of the Winter Solstice, that Timber will prove imsmortal: At leaft fhould it be from the twentieth to the thirtieth day, according to Columella : Cato four days after the Full, as far better for the growth : But all viminious Trees filente Luna $;$ fuch as Sallies, Birch, Poplar, \&c. Vegetiws for ship-timber, from the I5th, to the 25th, the Moon as before; but never during the Increase, 'Trees being then inoft abounding with moifture, which is the only fource of putrifaction.

25. Then for the Temper, and time of day: The woind low, neither East nor WeSt; neither in frosty, wet or dewy weather; and therefore never in a Fore-noone. Laftly, touching the $\beta_{e}$ ecies; Fell Fir when it begins to fpring; not only becaufe it will then beft quit its coat and ftrip; but for that they hold it will never decay in water; which howfoever Theophrast us deduce from the old Bridge made of this material over a certain River in Arcadia, cut in this feafon, is hardly fufficient to fatisfie our inquiry. 26. Previous to this work of Felling is the advice of our Country-man Markbam, and it is not to be rejected : Survey ( $($ aith be) your Woods as they ftand immediately after Christ mas, and then divide the pecies in your mind; ( $I$ add, rather in fome Note Book, or Tablets) and confider for what purpofes every feveral kind is moft ufeful: After this, reckon the bad and good together, fo as one may put off the other, without being forc'd to glcan your Woods of all your beft Timber. This done (or before) you thall acquaint your felf with the marketable prices of the Country where your Fell is made, and that of rhe feveral forts; as what fo many inches, or foot square and long, is worth for the feveral imployments: What planks? what other fcantlings for fo many 
Spoaks, Naves, Rings, Pales; Spars, duc. allowing the roaste for the charges of Felling, duc. all which you fhall compute with greater certainty, if you have leifure, and will take the pains to cxamine fome of the Trees either by your own Fathom; or (nore accurately) by girting it about with a ftring, and fo reducing it to the fquare, $\mathcal{G}$ c. by which means you may give a neer guefs: or, you may mark fuch as you intend to $\mathrm{fell}_{\text {; }}$ and then begin your fale about Candlenas till the spring; before which you muft not (according as our Cuftom is) lay the $A x$ to the Root; though fome, for particular imployments, as for Iimber to make Plows, Carts, Axel-trees, Naves, Harrows, and the like Husbandry-tools, do frequently cut in ocfober.

Being now entering with your Workmen, one of the firf, and moft principal things is, the skilful disbrancbing of the Boal of all fuch Arms and Limbs as may endanger it in the Fall, wherein much forecalt and skill is requir'd of the Wood-man; fo many excellent Trees being utterly fpoiled for want of this only confideration: And therefore in arms of Timber which are very great, chop a nick under it clofe to the Boal, fo meeting it with the down-right ftrokes, it will be cut without $\beta$ licing.

27. Some there are who cut a kerfe round the body, almoft to the very pitch, or heart, and fo let it remain a while; by this means to drain away the moifture, which will diftill out of the wounded Veins, and is chiefly good for the moister fort of Trees: And in this work the very $A x$ will well tell you the difference of the Sex; the Male being fo much harder, and browner then the Female: But here (and wherever we fpeak thus of Plants) you are to underftand the analogical, not proper diftinction. Fell as clofe to the ground as poffible may be, if you defign a renafcency from the roots; unlefs you will grub for a total deftruction, or the ufe of that part we have already mention'd, fo far fuperiour in goodnefs to what is more remote from the Root. Some are of opinion, that the fecdling Oak, hould never be cut to improve his Boul; becaufe, fay they, it produces a reddifh wood not fo acceptable to the Work-man; and that the Tree which grows on the bead of his Motber does feldom prove good Timber : It is obferv'd, indeed, that one foot of Timber neer the Root (which is the proper kerfe, or cutting place) is worth three farther off: And haply, the fucceffor is more apt to be tender, then what was cut off to give it place; but let this be inquir ${ }^{\circ}$ into at leifure.

28. When your Tree is thus proftrate, Itrip off the Bark; and fet it $\int 0$ as it may beft dry; then cleanfe the Boal of the Brancbes which were left, and faw it into lengths for the fquaring, to which belongs the Meafure, and Girth (as our Work-men call it) which I refer to the Buyer, and to many fubfidiary Books lately printed, wherein it is taught by a very familiar and eafie Method: A Tun of Timler is forty folid feet, a load fifty.

29. If you are to remove your Timber, let the Dem be firft off, and the south-mind blow before you draw it : Neither fhould you by any means put it to ufe for three, or four moneths after, unlefs 
great neceflity urge you, as it did Duilius, who in the Punic War built his Fleet of Timber before it was feafon'd, being not above two moneths from the very Felling to the Launching: and as werealfo thofe Navies of Hiero after forty days; and that of Scipio, in the third Carthaginean War, from the very Forest to the Sea: - Fuly is a good time for bringing home your fell' $d$ Timber.

30. To make excellent Boards and Planks, "tis the advice of fome, you hould Barkyour Trees in a fit feafon, and fo let them ftand naked a full year before the felling; and in fome caifes, and grounds, it may be profitable : But let thefe, with what has been already faid in the foregoing chapters of the feveral kinds, fuffice for this Article : I Thall add one Advertifement of Caution to thofe Noble perfons, and others who have Groves and Irees of orna: ment neer their boufes, and in their Gardens in London, and the Circle of it ; efpecially, if they be of great ftature, and well grown; fuch as are the Groves in the feveral Inins of Court; nay; even that (comparatively, new Plantation) in my Lord of Bedfords Garden, $G_{c}$. and wherever they ftand in the more interiour parts of the City; that they be not over halty, or by any means perfwaded to cut down any of their old Trees, upon hope of new, more flourithing Plantations; thickning, or repairing deformities; becaufe they grow fo well when firft they were fet : It is to be confider'd how exceedingly that pernicious fmoak of the sea-coal is increas'd in and about London fince they were firft planted, and the buildings environing them, and inclofing it in amongt them, which does fo univerfally contaminate the Air, that what Plantations of Trees fhall be now begun in any of thofe places will have much ado, great difficulty, and require a long time, to be brought to any tolerable perfection: Therefore let them make much of what they have; and though I difcourage none, yet I can animate none to cut down the old.

\section{CHAP. XXX.}

\section{of Timber the Seafoning and LIfes, and of Fuel.}

T TE have before fpoken concerning fome preparations of Seaforing tanding Trees defign'd for Timber, by a half-cutting, difbarking, and the feafons of drawing, and ufing it.

r. Lay up your Timber very dry, in an airy place (yet out of the Wind, or Sun) and not ftanding upright, but lying along one. piece upon another, interpofing fome fhort blocks between them, to preferve them from a certain mouldine $\beta$ which they ufually contract while they $\int$ poeat, and which frequently produces a kind of fungis, efpecially if there be any fappy parts remaining.

2. Some there are yet, who keep their Timber as moint as they can, by fubmerging it in $W$ ater, where they let it imbibe to hinder 
th e cleaving; and this is good in Fir, both for the betterfripping and feafoning:

3. Some again coinmend Buryings in the Earth; others in Wheat; and there be feafonings of the Fire, as for the fcorching and hardning of piles which are to ftand either in the water, or the eartb: Thus do all the Elements contribute to the Art of seafoning.

4. And yet even the greeneft Timber is fometimes defirable for fuch as Carve and Turn; but it choaks the teeth of our Sams; and for Doors, Windows, Floors, and other clofe Works, it is altogether to be rejected; efpecially where Walnut-tree is the material, which will be.fure to fhrink : Therefore it is beft to chufe fuch as is of two or three years feafoning, and that is neither moift nor overdry; the mean is beft. Sir Hugh Plat informs us that the Venetians ufe to burn and fcorch their Timber in a flaming fire; continually turning it round with an Engine, till they have gotten upon it an hard,black, coaly cruft; and the fecret carries with it great probability; for that the wood is brought by it to fuch a hardnefs and drinefs, ut cum omnis putrifactio incipiat ab bumido, nor earth nor. water can penetrate it.; I my felf remembring to have feen Char. coals dug out of the ground amongt the ruines of ancient buildings, which have in all probability lain cover'd with earth above 1500 years.

5. Timber which is cleft is nothing fo obnoxious to rift and cleave as what is bewn; nor that which is $\int q u a r^{2} d$, as what is round; and therefore where ufe is to be made of huge and maffie columns, let them be boared through from end to end ; it is an excellent prefervative from fplitting, and not min-pbilosophical; though to cure this accident, the rubbing them over with a wax-cloatb is good, Painters Putty, \&cc. or before it be converted, the fmearing the Timber over with Cono-dung, which prevents the effects both of sun and Air upon it, if of neceffity it mult lye expos'd: Butbefides the former remedies I find this for the clofing of the chops and clefts of green Timber, to anoint and fupple it with the fat of poroder d-beef-broth, with which it muft be well foak'd, the chafm's fill'd with/punges dipt into it; this to be twice done over : Some Carpenters make ufe of greafe and $\int a w$-duft mingled; but the firft is fo good a way (fays my Autbor) that I have feen Wind-flock-tintber fo exquifitely clofed, as not to be difcerned where the defects were: This muft be us'd when the Timber is green: Finally,

6. I muft not omit to take notice of the coating of Timber in Work, us'd by the Hollanders for the prefervation of their Gates, Port-cullis's, Draw-bridges, sluces, and other huge Beanes and Contignations of Tinaber exfos'd to the Sun, and perpetual injuries of the Weather, by a certain mixture of Pitch and Tar, upon which they ftrew: finall pieces of cockle and cther fhells, beaten almoft to poxeder, and iningled with sea-fand, which incrufts and arms it after an incredible manner againft al! thefe aflaults and foreign invaders.

ves. $\quad 7$. For all ufes that Timber is efteem'd the beft which is the molt 


\section{A Difcourfe of Foreft-Trees.}

moft light, without knots, yet firm, and free from fap'; which is that fatty, whiter, and fofter part, call'd by the Anciénts Alburnum, which you are diligently to hew away : You thall perceive fome which has a piral convolution of the veins; but it is a vice proceeding from the feverity of unfeafonable $W$ inters, and defect of good nutriment.

8. Moreover, it is expedient that you know which is the Grain, and which are the Veins in Timber; becaufe of the difficulty of working againft it: Thofe therefore be the veins which grow largeft, and are fofter for the benefit of cleaving and hewing; that the Grain which runs in waves, and makes the divers and beautiful chamfers which fome woods abound in to admiration. The Grain of Beech runs two contrary ways, and is therefore to be wrought accordingly.

- 9. For the place of growth, that Timber is efteem'd beft which grows moft in the Sun, and on a dry and hale ground; The Climate contributes much to its quality, and the Northern fituation is preferr'd to the reft of the quarters; fo as that which grew in Tufcany was of old thought better then that of the Venetian fide; and Trees of the wilder kind, and barren, then the over much cultivated, and great bearers: but of this already.

I0. To omit nothing, Authors have fumm'd up the natures of Timber; as the hardeft Ebeny, Box, Larch, Lotus, Terebinth, Eugh, \&cc. which are beft to receive polifhing; and for this Lin-feed, or the fweeter Nut-oyl does the effect beft: Pliny gives us the Receipt, with a decoction of Walnut-fhales, and certain wild-pears: Next to thele, Oak for ships, and Honfes; Cornel, Holly, Evc. for Pins, Wedges, \&c. Cheß-nut, Horn-beam, Poplar, \&uc. Then for Bucklers, and Targets, were commended the more foft and moift; becaufe apt to clofe, fwell, and make up their wounds again; fuch as Willow, Lime, Birch, Alder, Elder, Afh, Poplar, \&c.

The Robur, or Wild-oak Timber, beft to ftand in ground; the Quercus without.

Pines, Pitch, Alder and Elm, are excellent to make Pumps and Conduit-pipes, and for all Water-works, \&c. Fir for Beams, Bolts, Bars; being tough, and not fo apt to break as the hardeft Oak. In fium, the more odoriferous Trees are the more durable and lafting.

II. We did, in Chap. 2 r. mention certain Subterranean Trees, which $\mathrm{Mr}$ Cambden fuppofes grew altogether under the ground: And truly, it did appear a very Paradox to me, till I both faw and diligently examin'd that piece (Plank, Stone, or both thall I name it) of Lignum foffile taken out of a certain Quarry thereof at Aqua Sparta not far from Rome, and fent to the moft incomparably learn'd Dr Ent, by that obliging Virtuofo Cavalier dal Pozzo. He that thall examine the bardne $\beta$, and feel the ponderonfne $\beta$ of it, firking in water. ouc. will eafily take it for aftone; but he that fhall behold its grain, fo exquifitely undulated, and varied, together with its colour, manner of heming, chips, and other moft perfect refemblarices, will never fcruple to pronounce it arrant mood. 
signor Stelluti (an Italiun) has publinhd a whole Tireatife exprefly to defcribe this.great curiofity : But, whiles others have PbiloSophiz ${ }^{2}$ according to their manner upon thefe extraordinary Concretions; fee what the moft induftrious, and knowing M. Hook, Curator of this Royal Society, has with no lefs Reafon, but more fuccinctnefs, obferv'd from a late Aicrofcopical Examen of another piece of petrifid-mood; the Defcription, and Ingenuity whereof cannot but gratifie the Curious, who will by this Inftance, not only be inftructed how to make Inquiries upon the like occafions; but fee alfo with what accuratenes the Society conftantiy proceeds in all their Indagations, and Experiments; and with what Candor they relate, and communicate them.

? 12. "It refembl'd Wood, in that

"Firft, all the parts of the petrifi"d fubftance feem'd not at all "cdillocated, or alter'd from their natural pofition whiles they

"were mood; but the whole piece retain'd the exact thape of "wood, having many of the confpicuous pores of wood ftill re" maining pores, and thewing a manifeft difference vifible enough " between the grain of the wood and that of the Bark; efpecially, "when any fide of it was cut fmooth and polite; for then it ap" pear'd to have a very lovely grain, like that of fome curious "clore wood.

"Next (it refembled wood) in that all the fmaller and (if fo I " may call thofe which are only to be feen by a good glafs) mi"crofcopical pores of it, appear (both when the fubftance is cut and "polinh'd tranfver $\Omega y$, and parallel to the pores) perfectly like the "Microfcopical pores of feveral kinds of pood, retaining both the " Thape, and polition of fuch pores.

"It was differing from wood.

"Firft, in weight, being to common water, as $3^{\frac{2}{4}}$ to $\mathrm{I}$. where"as there are few of our Englifh woods that, when dry, are found "to be full as heavy as water.

"Secondly, in hardnefs, being very neer as hard as a "Flint, and in fome places of it alfo refembling the grain of a "Flint : it would very readily cut Gla $\beta$, and would not without "difficulty (efpecially in fome parts of it) be feratch"d by a black " hard Flint: it would alfo as readily ftrike fire againft a steel, as "s alfo againft a Flint.

"Thirdly, In the clofenefs of it; for, though all the microec fcopical pores of the rood were very confpicuous in one pofition, "c yet by altering that pofition of the polifh'd furface to the light, " it alfo was manifert that thofe pores appear'd darker then the "reft of the body, only becaufe they were fill'd up with a more "dufky fubftance, and not becaufe they were hollow.

"Fourthly, in that it would not burn in the Fire; nay, though

"I kept it a good while red-hot in the flame of a Lamp, very in"cenfly caft on it by a blaft through a fmall pipe; yet it feem'd " not at all to have diminifh'd its extenfion; but only I found it " to have chang'd its colour, and to have put on a more dark, and "dufky brown bue." Nor could I perceive that thofe parts which "feem'd 
"f feem 'd to have been Wood at firft, were any thing wafted; but "c the parts appear'd as folid, and clofe, as before. It was farther "s obfervable alfo, that as it did not confume like wood; fo neither "sid it crack and liy like a Flint, or fuch like hard ftone; nor was " it long before it appeared red-bot.

"Fiftly, in its diffolublenefs; for putting fome drops of diftil"led Vinegar upon the ftone, I found it prefently to yield very "s many bubles, juft like thole which may be obferved in pirit of "Vinegar when it corrodes Coral; though I guel's many of thofe "bubbles proceeded from the fmall parcels of Air, which were "driven out of the pores of this petrifi'd fubftance, by the infinu" ating liquid menstruum.

"Sixthly, in its Rigidneß, and friability'; being not at all flexi"ble, but brittle like a Flint; infomuch that with one knock of a "Hammer I broke off a fmall piece of it, and with the fame bam"mer quickly beat it to pretty fine pomder upon an Anvil.

"Seventhly, it feem'd alfo very differing from wood to the "souch, feeling more cold then wood ufually does, and much like "other clofe Stones and Minerals.

"The Reafons of all which Pbenomona feem to be.

"That this petrifid wood having lain in fome place where it was "s well foaked with petrifying water (that is, fuch a roater as is well "c impregnated withftony and eartby particles) did by degrees le"parate, by fraining and filtration, or perhaps by precipitation, "co-bafion or co-agulation, abundance of ftony particles from that " permeating water, which ftony particles having, by means of the "fluid Vebicle, convey'd themfelves not only into the microfcopi"cal pores, and perfectly ftop'd up them; but allo into the pores; "which may perhaps be even in that part of the Wood which "s through the microfcope appears moft folid; do thereby fo aug"s ment the weight of the wood, as to make it above three times "heavier then water, and perhaps fix times as heavy as it was "when wood: next, they hereby fo lock up and fetter the parts "s of the wood, that the fire cannot eafily make them fly away, but " the action of the Fire upon them is only able to Char thofe parts, "c as it were, like as a piece of mood if it beclofed very faft up in "clay, and kept a good while red-bot in the fire, will by the heat "s of the fire be charr'd, and not confum'd; which may perhaps "be the Reafon why the petrifi'd fubftance appear'd of a blakifh "s brown colour after it had been burnt. By this intrufion of the "petrifi'd particles it alfo becomes hard, and friable; for the "Imaller pores of the mood being perfectly ftuffed up with thefc "ftony particles, the particles of the soood have few, or no pores "c in which they can refide, and confequantly, no flexion or yield"ing can be caus'd in fuch a fubstance. The remaining particles " likewife of the rood among the ftony particles may keep thein "from cracking and flying, as they do in a Flint.

Finally, for the ufe of our Chimneys, and maintenance of fire, $F_{u c l}$. the plenty of rood for Fucl, rather then the quality is to be looked after; and yet are there fome greatly to be preferr'd before 
others, as harder, longer-lasting, better beating, and cheerfully burning; for which we have commended the $A h_{2}, c_{c}$. in the foregoing Paragraphs, and to which I pretend not here to add much, for the avoiding repetitions; though even an History of 2. the beft way of Charking would not mif-become this Difcourfe.

3. - But in this penury of that dear Commodity, to incite all ingenious perfons, ftudious of the benefit of their country, to think of ways how our Woods may be preferved, by all manner of Arts which may prolong the lafting of our Fuel, I would give the beft encouragements. Thofe that thall ferioully confider the intolerable mifery of the poor Caucbi, the then inhabitants of the Low-Countries defcrib'd by Pliny, lib. I6.cap.I. (how opulent foever their late In"dustry has render'd them) for want only of wood for Fuel, will have reafon to deplore the exceffive decay of our former ftore of that ufeful Commodity; and by what hifts our Neighbours the Hollanders do yet repair that defect, be invited to exercife their inge. nuity: For befides the Dung of Beasts, and the Turf for their Chimneys, they make ufe of stoves both portable, and ftanding; and truly the more frequent ufe of thofe Inventions in our great, wafting Cities (as the cuftom is through all Germany) as alfo of thofe new, and excellent ovens invented by $D_{r}$ Keffler, for the incomparably baking of Bread, erc. would be an extraordinary expedient of hufbanding our Fuel; as well as the right mingling, and making up of Char-coal-dust, and loam, as tis hinted to us by Sir Hugh Plat, and is generally us'd in Mastricht and the Country about it ; then which there is not a more fweet, lafting and beautiful Fuel; The manner of it is thus:

4. Take about one third part of the fmalleft of any Coal, Pit, Sea or Char-coal; and commix them very well with loam (whereof there is in fome places to be found a fort fomewhat combuftible) make thefe up into balls, as big as an ordinary Cannon-bullet, or fomewhat bigger; or if you will in any other form, like brickbats, \& $c$. expole thefe in the air till they are throughly dry; they will be built into the moft orderly fires you can imagine, burn very clear, give a wonderful heat, and continue a very long time.

Two or three fhort Billets cover'd with Char-coal laft much longer, and with more life, then twice the quantity by it felf, whether Char-coal alone, or Billet; and the Billets under the Char-coal bcing undifturb'd, will melt as it were into Char-coals of fuch a lafting fize.

If small-coals be fpread over the char-coal, where you burn it alone, 'twill bind it to longer continuance; and yet more, if the small-coal be made of the roots of Thornes, Briers and Brambles. Confult L.Bacon, Exp. 775 .

The sea-weed which comes in our oyfter-barrels laid under New-Castle-coal to kindle it (as the ufe is in fome places) will (as I an inform'd) make it out-lant two great fires of fimplecoals, and maintain a glowing luculent heat without wafte: It was not try'd by my Friend, what it would do as to Fuel burnt by it felf; but, that it adds much life, continuance and aid, to our fullen Sea- 
coalfuel; and if the main Ocean thould afford Fuel, (As the Bernacles and soland-Geefe are faid to do in fome parts of scotland with the veryfticks of their Nests) we in thefe Ifles may thank our felves if we be not warm : Thefe few particulars I have but mention'd to animate Improvements, and ingenious Attempts of detecting more cheap, and ufeful proceffes, for ways of charking-coals, Peat, and the like fuliginous materials; as the accomplinh'd M. Boyle has intimated to us in the Fift of thofe his precious Effays concerning the ufefulne/3 of Natural Philofophy, Part 2. cap. 7. O.c. to which I refer the curious.

6, By the Preamble of the Statute $7, E d .6$. one may perceive (the Meafures compar'd) how plentiful Fuel was in the time of Edward the 4 th to what it was in the Reigns of his Succeffors: This fuggefted a review of sizes, and a reformation of Abufes; in which it was Enacted, that every sack of Coals thould contain four Bufbels : Every Talegide to be four foot long, befides the carf; and if nam'd of one, marked one, to contain 16 inches circumference, within a foot of the middle : If of two marks, 23 inches.5 of 3.28 . of 4.35 ; of 5.38 . inches about, and fo proportionably.

6. Billets were to be of three foot, and four inches in length: the fingle to be 17 inches and an half about; and every Billet of one cajt (as they term the mark) to be ten inches about: of two caft, fourteen inches, and to be marked (unlefs for thie private ufe of the Omoner) within fix inches of the middle: of one caft within four inches of tlie end, \& $c$.

Every bound F agot thould be three foot long; the band twenty four inches circumference, befides the knot.

In the 43. Eliz. the fame statute (which before only concern'd London and its Suburbs) was made more univerfal; and that of Edw. 6. explain'd with this addition: For fuch Taleghides as were of neceffity to be made of clefi-noood, if of one mark, and half round, to be 19 inches about; if quarter-cleft, 18 inches $\frac{1}{2}$ : Marked two, being round it thall be 23 inches compafs : half-round 27 : quarter-cleft $26:$ marked three, round $28:$ half-round $33:$ quarter-cleft 32 : marked four, being round 33 inches about: halfround 39 : quarter-cleft $38:$ marked five round, 38 inches about : half-round 44 : quarter-cleft 43 : the meafure to be taken within half a foot of middle of the length mention'd in the former statute.

Then for the Billet every one nam'd a fingle; being round to have 7 inches $\frac{1}{2}$ circumference; but no fingle to be made of cleft wood : If marked one, and round, to contain I I inches compafs : if half-round 13 : quarter-cleft $12 \frac{1}{2}$.

If marked two, being round, to contain 16 . inches : halfround $19:$ quarter-cleft $18 \frac{1}{3}:$ the length as in the statute of King Ed.6.

7. Fagots to be every ftick of three foot in length, excepting only one ftick of one foot long, to harden and wedge the binding of it: This to prevent the abufe (too much practis'd) of filling the middle part, and ends with trafh, and fhort fticks, which had been omitted in the former statute : concerning this and of 
the dimenfions of wood in the Stack, fee Chap. 27. to direct the lefs inftructed Purchafer : and I bave been the more particular upon this occafion; becaufe then our Fuel bought in Billet by the Notch (as they call it in London) there is nothing more deceitful; for by the vile iniquity of fome Wretcbes, marking the Billets as they come to the Wharf, Gentlemen are egregioutly chented. I could produce an inftance of a Friend of mine (and a Meriber of this Society) for which the Wood-monger has little caufe to brag; fince he never durft come at him, or challenge his Money for the Commodity he bought ${ }_{i}^{\prime}$ becaufe he durft not ftand to the meafure.

8. But I will now defcribe to you the Myftery of Charking (where of fomething was but touch'd in the Proceß of extracting Tar out of the Pines) as I receiv'd it from a moft induftrious perfon, and fo conclude the Chapter.

There is made of Char-coal ufually three forts, viz. one for the Iron-zoorks, a fecond for Gun-ponder, and a third for London and the Court, befides Small-coals, of which we fhall alfo fpeak in its due place.

We will begin with that fort which is us'd for the Iron-morks, becaufe the reft are made much after the fame manner, and with very little difference.

The beft Wood for this is good Oak, cut intolengths of three foot, as they fize it for the stack: This is better then the Cord-sood, though of a larger meafure, and much us'd in $s u \int e x$.

The wood cut, and fet inftacks ready for the Coaling; chufe out fome level place in the Copfe, the moft free from ftubs, \& $c$. to make the Heartb on: In the midft of this area drive down a ftake for your Centre, and with a pole, baving a ring faftrid to one of the extreams (or elfe with a Cord put over the Centre) defcribe a Circumference from twenty, or more feet femidiameter, according to the quantity of your zoood defign'd for coaling, which being neer may conveniently be charked in that Hearth; and which at one time may be $12,16,20,24$, even to 30 ftack: If 12 therefore be the quantity you will coal, a Circle whofe diameter is 24 foot, will fuffice for the Hearth; If 20 ftack, a diameter of 32 foots; If 30,40 foot, and fo proportionably.

Having thus marked out the ground, with Mattocks, haws and fit: Inftruments, bare it of the Turf, and of all other combuftible ftuft what foever, which you are to rake up towards the Peripherie, or out-fide of the circumference, for an ufe to be afterwards made of it; plaining, and levelling the ground within the circle: This done, the roood is to be brought from the neereft parts where it is $f_{a c k} d^{\prime}$, in wheel-barrows; and firft the fmalleft of it plac'd at the utmoft limit, or very margent of the Hearth, where it is to be fet long-ways, as it lay in the ftack; the biggent of the wood pitch, or fet up on end round about againft the jmall-mood, and all this within the circle, till you come within five, or fix foot of the centre; at which diftance you thall begin to fet the mood in a Triangular form (as in Fig. 2.A) till it come to be three foot high: 
Againft this again place your greater wood almoft perpendicular, reducing it from the triangular to a circular form, till being come within a yard of the centre you may pile the wood long-ways, as it lay in the ftack, being careful that the ends of the rood do not touch the Pole, ?which mutt now be erected in the centre, nine foot in beight, that fo there may remain a round bole, which is to be form'd in working up the ftack-wood, for a tunnel, and thel more commodious firing of the pit, as they call it. This provided for, go on to pile, and fet your wood upright to the other, as before; till having gain'd a yard more, you lay it long-ways again as was Thew'd: And thus continue the work, ftill enterchanging the pofition of the wood till the whole Area of the Hearth and Circle be fill'd, and pil'd up at the leaft eight foot ligh, and fo drawn in by degrees in piling, that it refemble the form of a copped brown Houf:bold-loaf, filling all inequalities with the fmaller truncbions till it lye very clore, and be perfectly, and evenly thaped. This done, then take fram, baume or ferne, and lay it on the out-fide of the bottom of the beap or wood, to keep the next cover from falling amongt the fticks : Upon this put on the turf, and caft on the dust and rubbif, which was grubb'd and raked up at the making of the Hearth, and referved neer the circle of it; with this cover the whole heap of mood to the very top of the pit, or tunnel, to a reafonable and competent thicknefs beaten clofe and even, that fo the fire may not vent but in the places where you intend it; and if in preparing the Hearth, at firft, there did not rife fufficient turf and rubbih for this work, fupply it from fome convenient place neer to your beap: There be who cover this again with a fandy, or finer mould, which if it clofe well need not be above an inch or two thick: This done, provide a screene, by making light burdles with $\int$ lits, rods, and ftraw of a competent thicknefs, to keep off the zoind; and broad, and high enough to defend an oppofite fide to the very top of your pit, being eight or nine foot; and fo as to be eafily remov'd as need thall require for the luing of your pit.

When now all is in this pofture, and the rood well rang'd, and clos'd, as has been directed, fet fire to your beap: But firft, you muft provide you of a Ladder to afcend the top of your pit: this they ufually make of a curved Tiller fit to apply to the convex fhape of the beap, and cut it full of notches for the more commodious fetting their feet whiles they govern the fire above; therefore now they pull up, and take away the ftake which was erected at the centre to guide the building of the pile, and cavity of the Tunnel. This done, put in a quantity of Char-coals (about a peck) and let them fall to the bottom of the Hearth; upon them caft in coals that are fully kindled; and when thofe which were firft put in are beginning to fink, throw in more fuel; and fo, from time to time, till the Coals have univerfally taken fire up to the top: Then cnt an ample, and reafonable thick turf, and clap it over the hole, or mouth of the Tunnel, ftopping it as clofe as may be with fome of the former duft and rubbilh. Laftly, with the handles of your Rakers, or the like, you muft makeVent-holes, or 
Registers (as our Chymists would name them) through the ftiff which covers your beap to the very. wood, thefe in ranges of two or three foot diftance quite round within a foot (or thereabout) of the top, though fome begin them at the bottom: A day after begin another row of boles a foot and half beneath the former; and fo more, till they arrive to the ground, as occafion requires. Note, that as the Pit does coal and fink towards the centre, it is continually to be fed with thort, and fitting mood, that no part remain unfir'd; and if it charks fafter at one part then at another, there clofe up the vent-boles, and open them where need is : - A pit will in this manner be burning off, and charking, five, or fix days, and as it coals the fmoak from thick and grofs clouds will grow more blew, and livid, and the whole mafs fink accordingly; fo as by thefe indications you may the better know how to ftop, and govern your fpiracles. Two or three days it will only require for cooling, which (the vents being ftopp ${ }^{\text {d) }}$ they affift, by taking now off the outward covering with a Rabil or Rubber; but this not for above the fpace of one yard breadth at a time; and firft they remove the courfert, and grofleft of it, throwing the finer over the beap again, that fo it may neither cool too haftily, nor endanger the burning and reducing all to Afjes, fhould the whole pit be uncover'd and expos'd to the air at once; therefore they open it thus round by degrees.

When now by all the former symptoms you judge it fully chark'd, you may begin to drans; that is, to take out the Coals, firft round the bottom, by which means the Coals, Rubbiflo and $D u f t$ finking and falling in together may choak, and extinguifi the fire.

Your Coals fufficiently cool'd, with a very long-tooth'd Rake, and a Vann, you may load them into the Coal-mains, which are made clofe with boards, purpofely to carry them to Market : Of thefe Coals the groffer fort are commonly referv'd for the Forges, and Iron-works, the middling and fmoother put up infacks anù carried by the Colliers to London and the adjacent Towns; thofe which are chark'd of the roots, if pick'd out, are accounted beft for Chymicalfires, and where a lafting, and extraordinary blast is requir'd.

9. Coal for the Powder-mills is made of Alder-roood (but Limctree were much better had we it in that plenty as we eafily might) $c u t$, ftack'd, and fet on the Hearth like the former: But firft ought the rood to be wholly disbark'd (which work is to be done about Mid-fummer before) and being throughly dry it may be coaled in the fame method, the heap or pits only fomewhat fmaller, by reafon that they feldom Coal above five, or fix ftack, a time, laying it but two lengths of the wood one above the other, in form fomewhat : flatter on the top then what we have defcrib'd. Likewife do they fling all their rubbifh and duSt on the top, and begin not to cover at the bottom, as in the former example. In like fort, when they have drawn up the fire in the Tunnel, and ftopp'd it, they begin to draw down their dust by degrees round the heap; and this pro- 
portionably as it fires, till they come about to the bottom; all which is difpatch'd in the fpace of two days. One of thefe beaps will char threefcore facks of Coal, which may all be carried at one time in a Waggon; and fome make the Court-coals after the fame manner. Laftly,

IO. Small-conls are made of the $\beta$ pray, and brufh-mood which is Ihripped off from the branches of Copere-mood, and which is fometimes bound up into Bavins for this ufe $;$ though alfo it be as frequently charked without binding, and then they call it cooming it together: This they place in fome neer floor, made level, and freed of incumbrances, where fetting one of the Bavins or part of the Pray, onfire, two men ftand ready to throw on Bavin upon Bavin (as faft as they can take fire, which makes a very great and fudden blaze) till they have burnt all that lyes neer the place, to the number (it may be) of five, or fix hundred Bavins: But ere they begin to fet fire they fill great Tubs or Veffels with water, which ftand ready by them, and this they dafh on with a great difs or froup fo. foon as ever they have thrown on all their Bavins, continually plying the great beap of glowing Coals, which gives a fudden ftop to the fury of the fire, whiles with a great Rake they lay, and fpread it abroad, and ply their cafting of vater ftill on the Coals, which are now perpetually turn'd by two men.with great shovels, a third throwing on the water: This they continue till no more fire appears, though they ceafe not from being very hot: After this, theyfhovel them up into great beaps, and when they are throughly cold, put them up in facks for London, where they ufe them amongt divers Artificers, both to kindle greater fires, and to temper, and aneal their feveral Works.

The beft feafon for the fetching home of other $F u e l$, is from Fune; the mays being then inoft dry, and paffable.

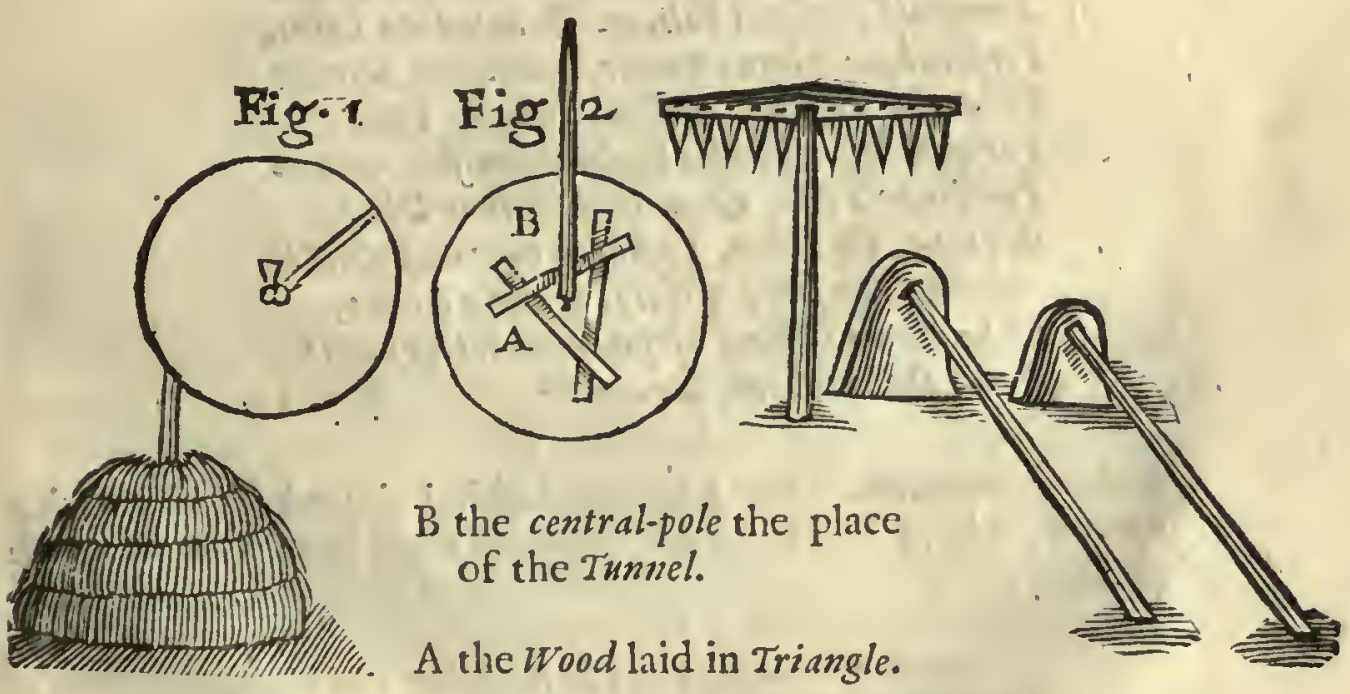

I I. And thus we have feen how for House-boot, and sbip-boot, Plow-boot, Hey-boot and Fire-boot, the Plasting, and Propagation 
of Timber and Forest-trees is requifite; fo as it was not for nothing, that the very name (which the Greeks generally apply'd to Timber) inn, by Senecbdoche, was taken always pro Materia; fince we hardly find any thing in Nature more univerfally ufeful; or, in comparifon with it, deferving the name of Material.

9. To fum up all the good qualities then, and tranfendent perfections of Trees, let us hear the harmonious Poets, in this confort of their Elogies :

Navigiòs pinos, domibus cedrófquis cuprefsófque; Hinc radios trivere rotis, binc tympana plaustris Agricole, \&u pandas ratibus pefuere carinas. Viminibus falices, frecunde froondibus vlmi : At Myrtus validis bastilibus, of bona bello Cornus: Ityreos Taxi torquentur in arcus. Nec Tïlia leves, ant torno rafile Buxum, Non formam accipiunt ferróque cavantur acuto. Nec non \& torrentem undam in levis innatat Alnus Miffa Pado; nec non o apes examina condunt corticibúfque cavis, vitiofség Ilicis alvo: Georg. 2.

and the moft ingenious ovid, where he introduces the miraculous Grove rais'd by the mclodious song of orphews,

- non chaonis abfuit arbor, Non nemus Heliadum, non frondibus afculus altis, Nec Tilia molles, nec Fagus, \&o innuba Laurus, Et Coryli fragiles, \&u Fraxinus utilis bastis; Enodifque Abies, curvataque glandibus Ilex; Et Platanus genialis, Acérque coloribus impar. Amnicoláque fimul Salices, ou aquatica Lotos, Perpetuóque virens Buxus, tenuéfque Myrica, Et bicolor Myrtus, \&u baccis cerula Ficus. Vos quoque flexi-pedes Heder veniftis, or una Pampinee Vites, o amicte Vitibus Vlmi, Ornique, \& Picee, Pomóque onerata rubenti Arbutus, ou lente victoris premia Palma, Et Juccinct a comas, birfut aque vertice Pinus Grat Deum matri, \&.c._ Met. 10.

as the incomparable Poet goes $\mathrm{cn}$, and is imitated by our divine spencer, where he brings his gentle Knight into a fhady Grove praifing

the Trees fo ftraight, and high,

The failing Pine, the Cedar protd, and tall,

The Vine-prop Elne, the Poplar never dry.

The builder Oak, fole King of Forests all; 
The Afpine, good for ftaves; the Cypreßfuneral :

The Laurel, meede of mighty Conquerours

And Poets fage; the Fir, that weepeth ftill;

The Willow, worn of forlorne Paramonrs;

The Eugh, obedient to the benders will;

The Birch for fhafts; the Sallow for the Mill;

The Myrrbe fweet bleeding in the bitter wound;

The war-like Beech; the $A$ f for nothing ill;

The fruitful olive, and the Platane round;

The Carver Holm; the Maple, feldom inward found.

Canto.I.

And in this symphony might the noble Taffo bear likewife his part; but that thefe are fufficient, of tria funt omnia. What now remains concerns only fome general Precepts, and Directions applicable to moft of that we have formerly touched; together with a Brief of what farther Lawos have been enacted for the Improvement, and prefervation of Woods; and which having difpatch'd, fhall with a fhort Parenefis touching the prefent ordering, and difpofing of his Majesties Plantations for the future benefit of the $\mathrm{Na}$ tion, put an end to this ruftick Difcourfe.

\section{CHAP. XXXI.}

Aphorifms, or certain general Præcepts of ufe to the foregoing Chapters.

I. TRy all forts of seeds, and by their thriving you thall bert 1 difcern what are the moft proper kinds for Grounds,

\section{Quippe folo natura fubest _-}

and of thefe defign the main of your Plantation.

2. Keep your newly fown feeds continually frefh, and in the forde (as much as may be) till they peep.

3." All curious feeds, and plants are diligently to be weeded till they are ftrong enough to over-drop or fupprefs them: And you Thall carcfully haw, balf-dig, and ftir up the earth about their Roots during the firft three years; efpecially in the Vernal, and Autumnal Aquinoxes: This work to be done in a moist feafon for the first year to prevent the duft, and the fuffocating of the tender buds.; but afterwards in the more dry weather.

4. Flants rais'd from feed, fhall be thinn'd where they come up too tbick; and none fo fit as you thus draw to be tranglanted into Hedge-rows; efpecially, where ground is precious.

5. In tranjplanting, omit not the placing of your Trees towards their accuftom'd $A$ pect.

6. Remove the foftest wood to the moifteft grounds, 


\section{Divife arboribus patrie}

7. Begin to Tranfplant Foreft-trees when the leaves fall after Michaclines; you may adventure when they are tarniffo ${ }^{\circ} d$, and grow yellow : It is loft time to commence later, and for the moft part of your Trees, early Tranplanters feldom repent; for fometimes a tedious band of Froft prevents the whole feafon, and the baldne $\beta$ of the Tree is a note of deceipt; for fome oaks, and moft Beeches, preferve their dead-leaves till new ones pulh them off.

8. Set deeper in the lighter grounds than in the frong; but fhalloweft in Clay : five inches is fufficient for the dryeft, and one or two for the moift, provided you eftablinh them againft winds.

9. Plant forth in warm, and moift feafons; the Air tranquil and ferene; the wind wefterly; but never whiles it actually freezes, rains, or in mifty weather; for it moulds, and infects the Roots.

10. What you gather, and draw out of Woods, plant immediately, for their roots are very apt to be mortified by the winds and cold air.

I1. Trees produc'd from feeds muft have the Tap-roots abated (the Walnut-tree, and fome others excepted) and the bruifed parts cut away; but fparing the fibrows, for they are the princi- . pal feeders; and thofe who cleanfe them too much, are punifh'd for the miftake.

I2. In pring rub off fome of the Collateral Buds, to cheek the exuberancy of fap in the Branches, till the Roots be well eftablifh'd.

13. Tranßplant no more then you well Fence; for that neglected, Tree-culture comes to nothing : Therefore all young fet Trees fhould be defended from the winds, and sun; efpecially the Eaft, and Nortb, till their roots are fixed; that is, till you perceive them. floot; and the not exactly obferving of this Article is caufe of the perifhing of the molt tender Plantations; for it is the invalion of thefe two affailants which does more milchief to our new fet, and lefs hardy Trees, then the mott fevere and durable Frofts of a whole winter.

I4. The propereft $\int o i l$, and molt natural, apply to diftinct species, Nec vero terre ferre omines omniapofjunt. Yet we find by experience, that moft of our Forest-trees grow well enough in the courfeft lands; provided there be a competent depth of mould: For albeit moft of our wild plants covet to run juft under the furface, yet where there is not fufficient depth to cool them, and entertain the Moifture and Infuences, they are neither lafting, nor profperous.

15. Wood well planted will grow in Moorifh, Boggy, Heathy, and the ftoniest grounds: Only the white and blew Clay (which is commonly the beft Pafture) is the worft for wood'; and fuch gcod Timber as we find in any of thefe (Oaks excepted) is of an 
exceflive age, requiring thrice the time to arrive at their ftature:

16. If the feafon require it, all new Plantations are to be plied with waterings, which is better pour'd into a circle at fome diftance from the Roots, that percolating through a quantity of earth it may carry the nitrous virtue of the foil with it; and by no means at the ftein; becaufe it walhes the mould from the Root, comes toocrude, and endangers their rotting: But,

17. For the cooling, and refrefhing Tree-roots, the congefting of Flints, or Pibbles neer three foot of the ftem, is preferable to all other; and fo the Poet,

Aut lapidem bibulum, ant fquallexteis infode conchas, Inter enim labentur aque, tenuifque fubibit

Halitus

Georg. 2.

18. Cut no Trees when either beat, or cold are in extreams; nor in very wet; or fnowy weather; and in this work it is profitable to difcharge all Trees of unthriving, broaken, wind-lhaken, browe e, and fuch as our Laws terms Cablicia, and to take them off to the quick,

ne pars fincera trabatur.

Many more ufeful Obfervations are to be collected, and added to thefe, from the diligent experience of Planters.

\section{CHAP. XXXII.}

\section{of the Laws and Statutes for the Prefervation, and Improvement of Woods, Evc.}

1. TO let pafs the Lams; and civil Conftitutions of great $A n$ tiquity, by which Servius informs us 'twas no lefs then Capital, alienas arbores incidere; the lex Aquilia, and thofe of the xii. Tabb.mention'd by Paulus, Cajus, Fulianus and others of that Robe repeated divers more. "The wife solon prefcribed Ordinances for the very diftances of Trees; as the divine Plato did againft ftealing of Fruit, and violating of Plantations : And the interdiction de Glande legenda runs thus in Vlpian, $A I T$ PRAETOR, GLANDEM, 2UAE EX ILLIVS AGRO IN TUVM CADIT, ¿VO MINUS ILLI.TERTIO QVOQVE DIE LEGERE AUFERKE LICEAT; VIM FIERI VETO. But it is not bere that I delign to enlarge, as thofe who have philologiz'd on this occafion de sycophantis, and other curious Criticifmes; but pals on, and confine my felf to the prudent Sanctions of our own Parliaments, which I deduce in this order.

2. From the time of Edroard the fourth, were enacted many

$$
\text { Q2 excel- }
$$

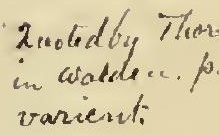

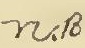


excellent Lams. for the planting, fecuring, cutting, and ordering of Woods, $\operatorname{cop} \int e s$, and Under-moods, as then they took cognizance of them; together with the feveral penalties upon the Infringers; cfpecially from the 25. of Hen. 8.17. duc. confirm'd by the 13. and 27. of Q.Eliz. cap.25.19. Kuc. which are diligently to be confulted, revived, put in execution, and enlargd where any defect is apparent; as in particular the $A C Z$ of exempting of Timber of 22 years growth from Tythe, for a longer period, to render itcompleat, and more effectual to their Improvement: And that Law repealed, by which Willows, Sallows, Oziers, \&c. which they term Sub-bois, are reputed but as Weeds.

3. Scverer punifoments have lately been ordain'd againft our Wood-ftealers, deftroyers of young Trees, \&c. I cannot fay they are fharp ones, when I compare the feverity of our Laws againft Mare-ftealers; nor am I by inclination the leaft cruel; But I do affirm, we might as well live without Mares, as without ships, which are our trooden, but no lefs profitable Hor Jes.

4. Ihave heard, that in the great Expedition of 88 , it was exprefly enjoyn'd the spanifh Commanders of that fignal Armada; that if when landed they fhould not be able to fubdue our Nation, and make good their conqueft; they fhould yet be fure not to leave a Treeftanding in the Foreft of Dean: It was like the Policy of the Philiftines, when the poor Ifraelites went down to their Enemies smiths to fharpen every man his Tools; for as they faid, left the Hebrems make them smords, or spears; fo thefe, left the Englifh buitd themi ships, and Men of War: Whether this were fo, or not; certain it is, we cannot be too jealows for the prefervation of ourWoods; and efpecially of thofe eminent, and with care inexhauftible Magazines: I dare not fuggent the encouragement of a yet farther reftraint, that even Proprietors themfelves fhould not prefume to make havock of fome of their own Woods, to feed their prodigality, and heap fuel to their vices; but it is worthy of our obfervation, that (in that in-imitable Oration, the fecond Philippic) Cicero does not fo tharply reproach his grcat Antagonift for any other of his extravagancies (which yet hic there enumerates) as for his wafteful difpofure of certain Wood-lands belonging to the Commonmealth, amongft his jovial Bravo's, and leud companions; tua ifta detrimenta funt (meaning his Debanches) illa noftra; fpeaking of the Timler.

15. But to the Lams: it were to be wilh'd that our tender, and improvable Woods, thould not admit of Cattle, by any means, till they were quite grown out of reach; the. Statutes which connive at it, in favour of Cuftom, and for the fatisfying of a few clamorous, and rude commoners, being too indulgent; fince it is very evident that lefs then a 14 or 15 years enclojure. is, in moft places, too foon; and our moft materinl Trees would be of infinite more worth and improvement, were the standards fuffer'd ro grow to Timber, and not fo frequently cut, at the next Felling of the Wood, as the general cuftom is. In $22 . \mathrm{Edm}$. 4. the liberty arriv'd but to feven years after a felling of a Forest or' Purlien; and a.t. In but 
but three years before, without fpecial licenfe: This was very narrow; but-let us then look on England as an over-grown Country.

6. Wood in Parks was afterwards to be four years fenced upon felling : and yearling Colts, and Calves might be put into inclofed Woods after two: By the r3. Eliz. five years, and no other Cattle till fix, if the growth was under fourteen years; or untill eight, if exceeding that age till the laft felling : All which statutes being by the ACt of, Hen. 8. but temporal, this Parliament of Eliz. thought fit to make perpetual.

7. Then to prevent the deftructive razing and converting of Woods to Pafture : No wood of two Acres, and above two furlongs from the Manfion houfe, thould be indulg'd: And the probibitions are good againf $A$ /Jarts made in Forests, \& $c$. without $l i$ cenfe: Thé penalties are indeed great; but how feldom inflicted; and what is now more eafie, then compounding for fuch a license? In fomepdrts of Germany, where a fingle Tree is obferv'd to be extraordinary fertile, a conftant, and plentiful Maft-bearer ; there are Laws to prohibite their felling without fpecial leave: And it was well Enacted amongtt us, that even the.Omners. of Woods within Clsajes thould not cut down the Timber without view of officers; or if not within chafes, yet where a common-perfon had liberty' of $c h a f e, \& c$. and this would be of much benefit, had the Regarders perform'd their duty, as 'tis at large defcrib'd in the Writ of the 12. Articles; and that the Surcharge of the Forefts had been honefly infpected with the due Perambulations, and ancient Metes : Thus fhould the Fustices of Eire difpore of no Woods without exprefs Commiffion, and in convenient places : Minuti blaterones quercunm, culi, \& curbi, as our Law, terms wind-falls, dotterels, fcrags, coc. and no others.

8. Care is likewife by our Lans to be taken that no unneceffary Imbezelment be made by pretences of Repair of Paling, LodgesBrome for Deer, \&c. Wind-falls, Root-falls; dead, and sear-trees; all which is fubject to the Infpection of the Warders, $7 u s t i c e s, d u c$. and cven trefpaftes done 'de Viridi on boughs of Trees, Thicket's and the like; which (as has been thew'd) are very great impediments to their growth and profperity; be duly looked after, and punilhed: See Confuet. or AJJif. Foreft. Pannagium, or Paftura pecorum ou de Glandibus, Flet $a$, \& c. Man-moods Forèft-Laws : Cook pla.fol. 366. li. 8. fol. 138 .

9. Finally, that the exorbitance; and increafe of devouring Iron-mills were looked into, as to their distance, and number neer the seas, or navigable Rivers; And what if fome of them were even remov'd into another World? 'twere better to purchafe all our Iron out of America, then thus to exhauft our Woods at bome, although (I doubt not) they 'might be fo order'd, as to be rather a means of conferving them. There was a Statute, made by Queen Eliz. to prohibite the converting of Timber-trees to Coul, or other Fuel for the ufe of Iron-mills; if the Trce were of one foot fquare, and growing within. I 4 miles of 
the sea, or the greater Rivers, fuc. 'tis pity fome of thofe places in Kent, suffex and surrey were excepted in the Provifo, for the reafon exprefs'd in a statute made 23. Eliz. by which even the imploying of any under-mood, as well as great Trees, was prohibiced within 22 miles of Iondon, and many other navigable Rivers, Creeks, and other leffer diftances from fome parts of sufjex Downs, Cinque-ports, Havens, \& c.

10. And yet to prove what it is to manage Woods difcreetly; I reade of one Mr Cbriftopher Darell a surrey. Gent. of Nudigate, that had a particular Indulgence for the cutting of bis Woods at pleafure, though a great Iron-mafter; becaufe he fo order'd his Works, that they were a means of preferving even his Woods; notwithftanding thofe unfatiable devourers: : This may appear a $\mathrm{Pa}$ radox, but is to be made out; and $I$ have heard my own Fatber (whofe Eftate was none of the lealt rooded in England) affirm, that a Forge, and fome other Mills, to which he furnifh'd much Fuel, were a means of maintaining, and improving his Woods; I fuppofe, by increafing the Induftry of planting, and care; as what he has now left ftanding of his own planting, enclofing and cherifsing in the pol/e/fion of my moft honour'd Brother, Geo. Evelin of Wotton in the fame County, does fufficiently evince; a moft laudable Monument of his Induftry, and rare Example.

II. The fame ACt we have confirmed, and enlarg'd in the i 7 th of the faid $2 u c e n$, for the preferving of Timber-Trees, and the.penalties of impairing Woods much, increafed; the tops, and offals only permirted to be made ufe of for this imployment: But let us fee what others do.

12. The King of spain has neer Bilbao fixteen times as many Acres of $\operatorname{cop} \int e-2000 d$ as are fit to be cut for Coal in one year; fo that when 'tis ready to be fell' $d$, an officer firft marks fuch as are like to prove sbip-timber, which are let fand, as fo many facred, and dedicite Trees: But by this means the Iron-woorks are plentifully fupplied in the fame place, without at all diminifhing the ftock of Timber. Then in Bifcaylagain, every proprietor, and other, plants three for one which he cuts down; and the Law obliging them is moft feverely executed. There indeed are few, or no copfes; but all are Pollards; and the very lopping (I am affur'd) does furnifh the Iron-works with fufficient to fupport them.

13. What the practice is for the maintaining of thefe kind of Plantations in Germany, and France, has already been obferv'd to this Illuftrious Society by the learned Dr Meret; viz. that the Lords and (for the Crown-lands) the. Kings Commiffioners, divide the Woods, and Forejts, into eighty partitions; every year felling one of the divifions; fo as nowood is fell'd in lefs then fourfcore years: And when any one partition is to be cut down, the officer, or Lord contracts with the Buyer that he flall at the diftance of every twenty foot (which is fornewhat neer) leave a good, fair, found and fruitful orkftanding. Thofe of 'rwixt forty, and fifty years they reckon for the beft, and then they are to fence thele Trees from all forts of Beafts, and injuries, for a competent time; which 
bcing done, at the feafon, down fall the Acorns, which (with the Autumnal rains beaten into the eartb) take root, and in a fhort time furnifh all the Wood again, where they let them grow for four, or five years; and then grub up fome of them for Fuel, or tranplantions, and leave the inoft provable of them to continue for Timber.

14. The. French King permits none of his Oak-woods, though belonging (fome of them) to Monfleur (his Royal Brother) in Appenage, to becut down; till his own surveyors, and officers, have firft marked them out; nor are any fell'd beyond fuch a circuit: Then are they fufficiently fenc'd by him who buys; and no cattle whatfoever fuffer'd to be put in, till the very feedlings which fpring up of the Acorns are perfectly out of danger. And to thefe I might fuperadd divers others, but I haften to an end.

The Parænefis, and Conclufion.

I. Since our Forefts are undoubtedly the greateft Magazines of the wealth, and glory of this Nation; and our Oaks the trueft Oracles of the perpetuity of our happine $\beta$, as being the only fupport of that Navigation which makes us fear'd abroad, and flourifh at Home; it has been ftrangely wonder'd at by fome good $\mathrm{Pa}$ triots, how it comes to pars that many Gentlemen have frequently repair'd, or gain'd a fudden Fortune, with plowing part of their Parks, and fetting out their fat grounds to Dutch-gard'ners, Juc. $^{2}$ and very.wild Wood-land parcels (as may be inftanc"d in feveral places) to dreffers of Hop-yards, ouc. whiles the Royal portion lyes foldced up in a Napkin, uncultivated, and neglected; efpecially, thofe great, and ample Forefts; where though plowing, and fowing has been forbidden, a Royal command, and Defign, may well difpenfe with it, and the breaking up of thofe Intervals advance the growth of the Trees to an incredible Improvement.

2. It is therefore infifted on, that there is not a cheaper, eafier, or more prompt expedient to advance ship-timber, then to folicit, that in all his Majefties Forefts, Woods, and $P$ arks, the fpreading Oak (which we have formerly defcribed) be cherifh'd, by plowing, aind fowing Barley, Rye, Guc. (with due fupply of culture, and foil, between them) as far as may (without danger of the Plow-fbare) be broken up. But this is only where thefe Trees are arriv'd to fome magnitude, and ftand at competent diftances; a bundred, or fifty yards (for their Roots derive relief far beyond the reach of any. boughs) as do the Walnut-trees in Burgundy, which ftand in their beft plow'd-lands.

3. But that we may particularize in his Majefties Forefts of Dean, sherenood, \&c.and in fome fort gratifie the Queries of the Honourable the principal officers and Commiffioners of the Nivy; I am advis'd by fuch as are every way judicious, and of long experience in thore parts; that to enclofe would be an excellent way : But it is to be confider'd, that the people, viz. Forefters and Bordurevs, are not generally fo civil, and reafonable, as might be wilhed; and there- 
fore to defign a folid Improvement in fuch places, his Majesty muft affert his power, with a firme and high Refolution to Reduce thefe men to their due obedience, and to a neceffity of fubmitting to their own, and the publickutility; though they preferv'd their industry this way at a very tolerable rate upon that condition, whiles fome perfon of trust, and integrity did regulate, and firpervife the Mounds and Fences, and deftine fome portions frequently fet a part, for the,raifing, and propagating of Woods, till the whole Nation were furnifh'd for pofterity.

4. And which work if his Majefty fhall refolve to accomplith, he will leave fuch an everlanting obligation on his people, and raife fuch a Monument to his Fame, as the Ages for a thoufand years to come Shall have caufe to celebrate his precious memory, and his Royal succeffors to emulate his Virtue. For thus (befides the future expectations) it would in prefent be no deduction from his Majefties Treafure; but fome increafe; and fall in time to be a fair, and worthy Acce/fion to it; whiles this kind of propriety would be the moft likely expedient to civilize thofe wild and poor Bordurers; and to fecure the vant and fpreading heart of the Foreft, which with all this Induigence would be ample enough for a Princely Demeafnes : And if the difficulty be to find out who knows, or acknowledges what are the Bordures; this Article were worthy, and becoming of as ferious an Inquifition, as the Legifative power of the whole Nation can contrive.

5. The Sum of all is; get the Bordures well Tenanted, by long Terms, and eafie Rents, and this will invite and encourage Takers; whilft the middle, moft fecure, and interiour parts would be a koyalportion. Let his Majefty therefore admit of any willing Adventurers in this valf Circle for fuch Enclofures in the Precincts; and rather of more, then of few, though an bundred, or two fhould joyn together for any Enclofure of five bundred Acres more, or lefs; that multitudes being thus engaged, the confideration might procure, and facilitate a full difcovery of latter Encrochments, and fortifie the recovery by favourable Rents, Improvements and Reverfions by Copy-bold, or what other Tenures and services his Majesty fhall pleafe to accept of.

6. Now for the planting of Woods in fuch places (which is the only defign of this whole Treatife) the Hills, and rough Grounds will do well; but they are the rich fat Vales, and flats which do beft deferve the charge of Walls; fuch as that $\mathbb{P o t}$ affords; and the Haw-thorn well plafh'd (fingle or double) is a better, and more natural Fence then unmorter $d$ malls, could our induftry arrive to the making of fuch, as we have defcrib'd: befides, they are lafting, and profitable; and then one might allow fufficient bordare for a Mound of any thicknefs, which may be the firnt charge, and well fupported, and "rewarded by the culture of the Land thus exclofed.

7. For Example, fuppofe a man would take in 500 Acres of good Land, let the Mounds be of the wildeft ground, as fittert for mood: Two bedges with their Valations, and Trenches will be requifite 


\section{A Difcourfe of Foreft-Trees.}

requifite in all the Round; viz. one next to the Enclofure, the other about the Thicket to fence it from Cattle. This between the two hedges (of whatfoever breadth) is fittef for Plantation: In thefe hedges might be tryed the plantation of ftocks; in the intervals all manner of wood-feeds lown (after competent plowings) as Acorns, Mast, Fir, Pine, Nuts, \&uc. the firft year chafing away the Birds, becaufe of the Fir and Pine feeds, for reafons given; the fecond year loofning the ground, and thinning the fupernumeraries, \&uc, this is the mof frugal way : Or by another Method the Wafte places of Forefts and Woods: (which by through experience is known and tried) might be perfectly extirpated; and then allowing two or three plowings, well-rooted ftocks be fet, cut and trimm'd as is requifite; and that the Timber-trees may be excellent, thofe after wards copfed, and the choicent ftocks kept Threaded. If an Enclofure b.e low'd, the seeds may be (as was directed) of all the pecies, not forgetting the beit Pines, Fir, \& whiles the yearly removal of very incumbrances only will repay the Work-men, who fell the Quick, or referve it to ftore other Enclofurcs, and foften the circumjacent grounds to the very great improvement of what remains.

9. And how if in fuch Fencing-morks we did fometimes imitate what 2uintws Curtius, lib. 6. has recorded of the Mardorum gens, neer to the Confines of Hyrcania, who did by the clofe planting of Trees alone upon the bordures give fo Arange a check to the power of that great Conqueror'Alexander? They were a barbarous people indeed, but in this worthy our imitation; and the work fo handfomly and particularly. defcrib'd that I thall not grieve to recite it. Arbores den $\int e$ font de induftria confete, quarumi teneros adbuc ramos manu flectunt, quos intortos rurfus inferunt terre: Indevelut ex alia radice letiores virent trunci : bos, qua naturafert, adolefcere non finunt: quippe alium alii, quafi nexu conferunt: qui ubi mult a fronde veftiti funt, operiunt terram. Itaque oc: culti ramorum velut laquei perpetuâ fepe iter claudunt, \&uc. The Trees ( $\left.\int a i t h ~ b e\right)$ were planted fo neer and thick together of purpofe, that when the boughs were yet young and flexible, bent and wreath'd within one another, their tops were bowed into the earth (as we fubmerge our Layers) whence taking frefh roots, they thot up new ftems, which not being permitted to grow as of themfelves they would have done, they fo knit and perplex'd one within another, that when they were clad with leaves, they even cover'd the ground, and enclofed the whole Country.with a kind of living net, and impenetrable liedge, as the Hiftorian continues the defcription. fuch works as thefe would become a Cato, or Varro indeed, one that were Pater Patric, nonfibi foli natus borin for PoAterity; but we are commonly of another mould,

10. A fair advance for fpeedy growth, and noble Trees (efpecially for Walks and Avenues) may be affuredly expected from the Graffing of young Oaks, and Elms with the beft of their kinds; and where the goodlieft of thefe laft are growing, the ground would be plow'd, and finely raked in the feafon when the scales 
fall; that the flowers and dews faftning the seed where the wind drives it, it may take root, and haften (as it will) to a fudden Tree; efpecially, if feafonable fhreading be appli'd, which has fometimes made them arrive to the height of twelve foot by the firft three years, after which they grow a main. And if fuch were planted as neer to one another as in the Examples we have alledg'd, it is almoft incredible what a paling they would be to our molt expos'd Plantations mounting up their wooden malls to the clouds: And indeed the fhelving and natural declivity of the Gronnd more or lefs to our unkind $A$ pects, and bleak Winds does beft direct to the thickning of thefe protections; and the benefit of that foon appear, and recompence our induftry in the fmoothnefsand integrity of the Plantations fo defended.

II. That great care be had of the seeds which we intend to fow has been already advifed; for it has been feen that Woods of the fame age,planted in the fame foil dilcover a vifible difference in the Timber and growth; and where this variety thould happen if not from the feed will be hard to interpret; therefore let the place, foil and growth of fuch Trees from whence you have your feeds be diligently examin'd; and why not this, as well as in our care of Animals for our breed and ftore?

I2. As to the Form, obey the natural fite, and fubmit to the feveral guizes; but ever declining to enclofe High-ways and Common-roads as much as poffible. For the reft, be pleafed to reflect on what we have already faid to encourage the planting of the large fpreading Oakabove all that $\beta$ pecies; the amplitude of the diftance which they require refign'd to the care of the Verderer for grazing Cattle, Deer, $\mathcal{C}^{c} c_{\text {. }}$ and for the great, and mafculine beauty which a wild Quincunx, as it were, of fuch Trees would prefent to your eye.

13. But to advance his Majesties Forefts to this height of perfection, I thould again urge the removal of fome of our moft mifchievous plac'd Iron-mills; if that at leaft be true which fome have affirm' $d$, that we had better Iron, and cheaper from Foreigners when thofe Works were ftrangers amongft us. I am inform'd that the New-Englifh (who are now become very numerous, and hindred in their advance and profpect of the Continent by their furfeit of the Woods which we want) did about twelve years fince begin to clear their High-ways by two Iron-mills : I am fure their zeal has fufficiently wafted our ftately Woods, and Stcel in the bowels of their Mother old England; and 'twere now but expedient their Brethren fhould haften thither to fupply us with Iron for the peace of our days; whilft His Majefty becomes the great $S o-$ vereign of the Ocean, frec Commerce, Nemorum Vindex of Inftaurator magnus. This were the only way to render both our Countries habitable indeed, and the fitteft facrifice for the Royal-Oaks, and their Hamadryad's to whom they ow more then a llight fubmiffion.

14. Another thing to be recommended (and which would prove no lefs then thirty years, in fome places forty, and generalJy twenty years advance) were a good, (if well executed $A C t$ ) to 
fave our standards and bordiring Trees from the Axe of the Neighbourhood: And who would not preferve Timber when within fo few years the price is almoft quadrupl'd? I affure you ftandards of 20,30 , or 40 years growth are of a long day for the concernments of a Nation.

15. And though we have in our general chapter of copses de: clar'd what by our Laws, and common ufage is expected at every Fell (and which is indeed moft requifite till our ftore be otherwife fuppli'd) yet might much even of that rigor be abated by no unfrugal permiffions to take down more of the standards for the benefit of the Under-moods (clpecially where by over-dropping, and Thade they interrupt the kindly dews, rains and influences which nourifh them) provided that there were a proportionable number of Timber-trees duly, and throughly planted, and preferved in the Hedge-rows and Bordures of our grounds: in which cafe even the total clearing of fome Copfes would be to their great advance, as by fad experience has been taught fome good Hufbands, whofe neceffities fometimes forced them to violate their standards, and more grown Trees during the late Tyranny.

16: Nor will it be here unfeafonable to advife, that where Trees are manifettly perceiv'd to decay, they be marked out for the Axe that fo the younger may coine on for a fupply; efpecially, where they are chiefly Elms; becaufe their fucceffors hatten to their height and perfection in a competent time; but beginning once to grow fick of age, or other infirmity, fuddenly impair, and lofe much of their value yearly : befides that the increafe of this, and other fpeedy Timber would fpare the more Oak, for Navigation and the fturdier ufes.

How goodly a fight were it if molt of the Demefnes of our Country Gentlemen were crown'd and incircl'd with fuch ftately rows of Limes, Firs, Elnts and other ample, thady and venerable Trees as adorn New-Hall in Efex, the Seat of that SuffolkKnight neer rarmouth, and our neighbouring Paftures at Earmes? Yet.were thefe Plantations but of late years in comparifon: It were a noble and immortal providence to imitate thefe good Husbands in larger and-more auguft Plantations of fuch ufeful trees for Timber and Fuel, as well. as for thade and ornament to our dwellings.

I 7. But thefe incomparable undertakings will beft of all become the Inpection and care of the Honorable Lieutenants, and Rangers; when they delight themfelves as much in the goodlinefs of their Trees, as other men generally do in their Dogs, and Horfes; for Races and Hunting; neither of which Recreations is comparable to that of Planting, either for virtue or pleafure, were things juftly confider'd according to their true eltimation : Not yet that I am of fo morese an bumour, that I reprove any of thofe noble, and manly Diverfions feafonably us'd; but becaufe I would court the Industry of great, and opulent perfons to profitable and permanent delights: For luppofe that Ambition were chang d. into a laudable emulation who thould beft, and with moft artifice, raife a Plantation of Trees that fhould have all the proper orna- 
ments, and perfections their nature is fufceptible of by their direction and encouragement; fuch as Aflian fums up lib. 25. C. I4.

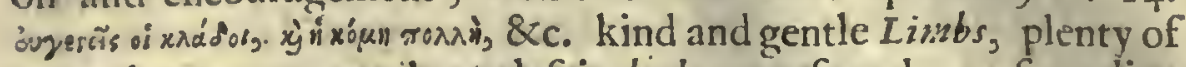
large leaves, an ample and fair body, profound or fpreading roots, ftrong againft impetuous winds (for fo I affect to read it) extenfive; and venerable frade, and the like: Methinks there were as much a fubject of glory as could be phancied of the kind; and comparable, I durft pronounce, preferable, to any of their Recreations; and how goodly an Ornament to their Demejnes and Dwellings, let their own eyes be the judges. But I now proceed to more general Concerns, in order to the 2 weries, and firft to the proportion.

18. It were but juft, and infinitely befitting the miferable needs of the whole Nation, that every twenty Acres of Pasture made an allowance for balf an Acre of Timber, to be planted in a clump, well preferv'd, and fenc'd for 14 ; or 15 years: And where the young Trees ftand too thick, there to draw, and tranplant them in the Hedge-rows, which would alfo prove excellent foelter for the Cattle: This Hiusbandry would more efpecially become Northamptonfire, Lincolnfhire, Cornwall, and fich other of our Conntries as are the moft naked of Timber, Fuel, \&rc. and unprovided of covert: For it is rightly obferv'd, that the moft fruitful places leaft abound in wood, and do moft ftand in need of it:

19. Such as are ready to tell ye their Lands are fo wet that their Woods do not thrive in them, let them be converted to $P a-$ fture; or beftow the fame induftry on them which good busbands do in Meadows by draining : It is a floathfulne/s unpardonáble; as if the pains would not be as fully recompenc'd in the growth of their Timber, as in that of their gra $\beta$ : Where poor hungry Woods grow, rich Corn, and good Cattle would be more plentifully bred; and it were beneficial to convert fome Wood-land (where the proper vertue is exhaufted) to Pafture and Tillage; provided that frefh land were improved alfo to mood in recompence, and to balance the other.

20. Where we find uliginons and ftarv'd places (which fometimes obey no Art or Induftry to drain, and of which our pale and fading Corn is a fure indication) we are as it were courted to obey Nature; and improve them for the propagation of sallyes, Willows, Alders, scycamore, Apine, Birch, and the like hafty and profitable grawers, by ranging them, cafting of Ditches, Trenches, $\mathcal{O} c$. as before has been taught.

$2 \mathrm{I}$. In the mean while 'tis a thing to be deplor'd, that fome perfons beftow more in grubbing, and dreffing a few Acres which has been excellent roood, to convert it into wretched pafture, not worth a quarter of what the Trees would have-yielded, well order' $\mathrm{d}$, and left ftanding; fince it is certain, that barren land plantcd with rood will trebble the expence in a fhort time : This I am able to confirm by inftancing a noble perfon, who (a little before our unhappy Wars) having fown three or four Acres with Acorns, the fourth year tranjplanted them, which grew too thick all about his 


\section{A Difcourfe of Foreft-Trees.}

Lordfsip: Theife Trees are now of that ftature, and fo likely to prove excellent Timber, that they are already judg' $\mathrm{d}$ to be almort as much worth as the whole Demefnes; and yet they take off nothing from other profits, having been difcreetly difpos'd of at the firft defignment. The Prince Elector Fredric. IV, in the year 1606: fow'd a part of that moft barren Heath of Lambertheini with Acorns after plowing, as I have been inform'd; it is now likely to prove a moft goodly Foreft, though all this while miferably neglected by reafon of the Wars.

The Right Honorable my Lord Vifcount Mouñtague has planted many thoufands of odks, which I ain told he draws out of copfes, big enough to defend themfelves; and that with fuch fuccefs as has exceedingly improv'd his poffelfions; and it is a worthy example. To conclude, I can thew an Avenue planted to a houfe ftanding in a barren Park, the foil a cold clay; it confifts totally of $0 a k s$, one hundred in number: The perfon who firft fet them (dying very lately) lived to fee them fpread their branches 123 foot in compafs, which at diftance of 24 foot mingling their (hady treffes for above 1000 in length, form themfelves into one of the moft venerable and ftately Arbour-Walks that in my life I ever beheld: This is at Baynards in surrey, and belonging to my mort honour'd Brother (becaufe a moft induftrious Planter of wood) Richard Evelyn Efq. The Walk is broad 56 foot, and one Tree with another containing by eftimation three quarters of a load of Timber in each Trce, and in their lops three Cord of fire-wood: Their bodies are not of the talleft; having been topped when they were young to reduce them to an uniform beight; yet is the Timber moft excellent for its fcantling, and for their heads few in England excelling them : where fome of their contemporaries were planted fingle in the Tark without cumber; they fpread above fourccore foot in arms.

22. I have produced thefe Examples becaufe they are $\operatorname{con} \beta \beta_{\text {i- }}$ cuows, full of encouragement, worthy our imitation; and that from thefe, and fundry others which I might enumerate, we have made this obfervation, that almoft any foil is proper for fome profitable Timiber-trees or other which is good for vcry little elfe.

23. The bottoms of Dorons and like places well plow'd, and Sown will bear lufty Timber, being broken up, and let lye till Midfummer, and then ftirr'd again before fowing about November: fo likewife in moft craggy, uneven, cold and expofed places, not fit for Arable, as in Bifiay, Evc. And it is truly from thefe Indications, more then from any other whatfoever, that a broken, and decaying Farmer is to be diftinguifh'd from a fubftantial Freebolder, the very Trees fpeaking the conditions of the Mafler: let not then the Royal Patrimony bear a Bankrupts reproach: But to defcend vet lower;

24. Had every Acre but three, or four Trees, and as many of Fruit in it as would a little adorn the Hedge-rows, the Improvement would be of fair advantage in a few years; for it is a thame that Turnep-planters thould demolifh and undo bedge-rows neer 
London, where the Mdunds and Fences are fripp'd naked to give sun to a few milerable Roots, which would thrive altogether as well under them being skilfully prun'd and lopp'd : Our Gard'ners will not believe me, but I know it to be true, though Pling had not affirm'd it: As for Elms. (faith he) their Jade is fo gentle and benigne, that it nourifhes whatfocver grows under it: and (lib. 17. c. 22.) it is his opinion of all other Trees (very few excepted) provided thcir branches be par'd away, which being difcreetly done, improves the Timber as we have already fhew'd.

25. Now let us calculate a little at adventure; and much within what is both faifible, and very polfible; and we fhall find, that four Fruit-trees in each Acre throughout England, the product fold but at fix pence the Bugel, will be worth above a Million yearly: What then may we reafonably judge of Timber, admit but at the growth of four penice per Acre yearly, (which is the loweft that can be eftimated) it amounting to neer two Millions? if (as 'tis fuppos'd) there may be five or fix and twenty Millions of fquare Acres in the Kingdom (befides Fens, High-ibays, Rivers, \&uc. not counted) and without reckoning in the Maft, or loppings, which whofoever thall calculate from the annual Revenue the Maft only of Weftphalia, a frall and wretched Country in Germany does yield to that Prince, will conclude to be no defpicable Intprovement.

26. In this poor Territory, every Farmer does by ancient cuftom plant fo many oaks about his Farme as may fuffice to feed his swine: To effect this, they have been fo careful, that when of late years the Armies inferted the poor Country, both Intperialifts, and Proteftants, the only: Bihoprick of Munster was able to pay eight bundred thoufand Crowns per menfem (which a mounts of our money to $25000 \mathrm{li}$. Starling) befides the ordinary entertainment of their own Prince and private Fanilies. This being incredible to be practis'd in fo extream barren a Country I thought fit to mention either to encourage, or reproach us:- General Melander was wont to fay, The good Hufbandry of thcir Ancestors had left them this ftock pro facra Anchora ${ }^{\prime}$. confidering how the People were afterward reduc'd to live even on-their Trees when the Souldiers had devour'd their Hogs; redeeming themfelves from great extremities by the Timber which they were at laft compell'd to cut down, and which, had it continu'd, would have proved the utter defolation of that whole Countrey. I have this Instance from my molt worthy and honourable Fricnd Sir William Curfius (His Majesties Refident in Germany,). who receiv'd this particular from the mouth of Melander himfelf : In like manner the Princes, and Freedoms of Hefe, saxony, Thuringia, and divers other places there, make vaft incomes of their Forest-fruit (befides the Timber) for swine only. I fay then, whofoever fhall duly confider this will finde planting of $W o o d$ to be no contemptible. Addition; befides the Pafture much improv'd, the cooling of fat, and heary Cattle, keeping them from injurious motions, difturbance and running as they 
do in summer to finde fselter from the beat, and vexation of Flyes:

27. But I have done, and it is now time for us to get out of the Wood, and to recommend this, and all that we have propos'd to His molt sacred Majesty, the Honourable Parliament, and to the Principal officers, and CommifJioners of the Royal Navy; that where fuch Improvements may be made, it be fpeedily, and vigorounly profecuted; and where any defects appear, they may be duly reformed.

28. And what if for this purpore there were yet fome additional office contituted, which fhould have a more univerfal Inpection, and the charge of all the Woods and Forests in His Majesties Dominions? This might eafily be perform'd by $D e$ puties in every County, Perfons judicious, and skilful in Hufbandry; and who might be repair'd to for advice and direction: And if fuch there are at prefent (as indeed our Laws feem to provide) that their Power be fufficiently amplified where any thing appears deficient; and as their zeal excited by worthy encouragements; fo might neglects be encounter'd by a vigilant and induftrious checque. It fhould belong to their Province to fee that fuch proportions of Timber, ojc. Were plant$e d$, and fet out upon every hundred, or more of Acres, as the Honorable Comini]froners have fuggett'd; or, as might be thought convenient, the quality, and nature of the placcs prudently confider'd : It thould be their office alfo to take notice of the growth, and decay of Woods, and of their fine/ 3 for publick $u$ es and fale, and of all there to give Advertifements, that all defects in their ill governing may be fpecdily remedied; and the Superiour officer, or surveyor fhould be accomptable to the Lord Treafurer, and to the principal officers of His Majesties Navy for the time being: And why might not fuch a Regulation be worthy the eftablifhing by fome solemn, and publick ACt of state becoming our glorious rrince SOVEREIGN O F T HE SEAS, and his prudent Senate this prefent Parliament?

29. We find in Ariftotles Politics the Conftitution of Extraturban Magiftrates to be Sylvarum Cuftodes, and fuch were the Confulares Sylve which the great Cafar himfelf (even in a time when Italy did abound in Timber) inftituted; and was one of the very firft things which he did at the fetling of that vaft Empire after the Civil Wars had exceedingly wafted the Country : Suetonius relates it in the life of Julius; and Peter Crinitus in his fifth Book De bonefta difciplina, c. 3. gives this reafon for it, $v t$ materies (faith he) non deeffet, qua videlicet Navigia publica poffent ì prefecturis Fabrikm confici: True it is, that this office was fometimes call'd Provincia minor; but for the moft part annex'd and joyn'd to fome of the greateft Confuls themfelves; that facetious farcafme of the Comedian (where Plautus names it Provincia caudicaria) referring onely to fome under-officer fubfervient to the other : And fuch a charge is at this day extant amongft the noble Venetians, and other prudent states; not to importune you with the exprefs Lams which Ancus Martius the Nephew of Numa, 
and other Princes long before Cefar did ordain for this very purpofe; fince indeed the care of fo publick and holiourable an Enterprize as is this of Planting, and Improving of Woods, is a right, noble and royal undertaking; as that of the Foreft of Dean, orc. in particular (were it bravely manag'd) an Imperial defign; and I do pronounce it more worthy of a Prince who truly confults his glory in the higheft Intereft of his subjects, then that of gaining Battels, or fubduing a Province : And if in faying $\mathrm{fo}_{\mathrm{g}}$ or any thing elfe in this ruftic Difcour $\int e$, I have us'd the freedom of a plain Forefter; it is the perfon you command me to put on, and my plea is ready,

Theocrisi

Sco.vide A dagixm.

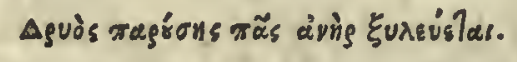

\section{Prafente Quercu ligna quivis colligit.}

for who could have fpoken le $\beta$ upon fo ample a subject? and therefore I hope my zeal for it in thefe Papers, will (befides your Injunctions) excufe the prolixity of this Digreffion, and all other the Imperfections of my Services.

si canimus Sylvas, Sylvæ Junt Confule digna.

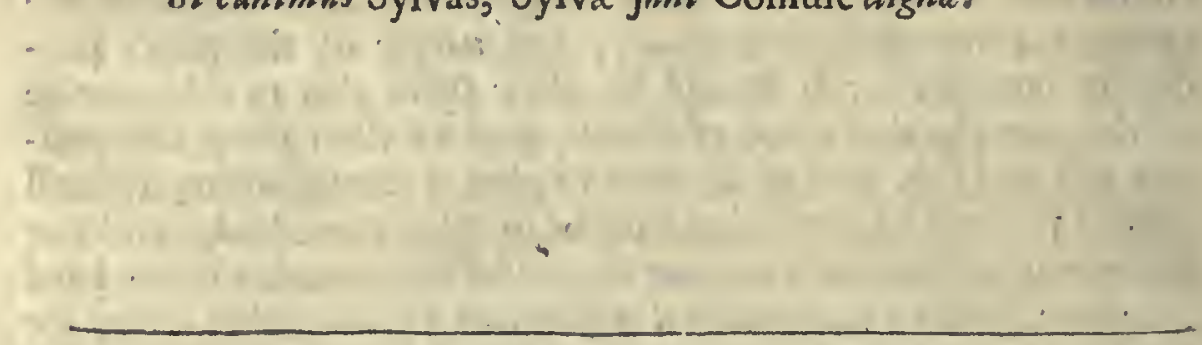

FIN I S. 


\section{POMONA,}

OR A N

\section{APPENDIX}

CONCERNING

\section{FRUIT-TREES, In relation to}
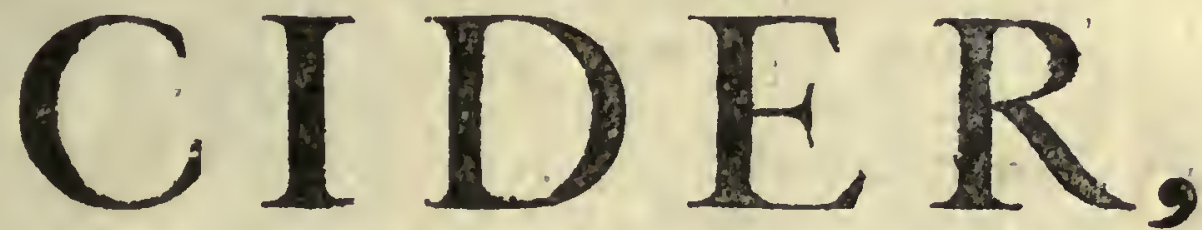

The Making and feveral ways of Ordering it.

V I R G. Eclog.ix.

Carpent tua Poma nepotes.

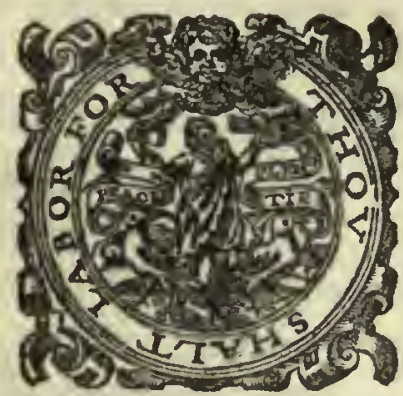

\section{LONDON,}

Printed by Fobn Martyn and Fames Alleftry, Printers to the Royal Society, and are to be fold at their Shop at the Bell in St Paul's Church-yard. MD C L XIV. 
in :

a. . 1941:597

$.237987+9195919$

2 mination

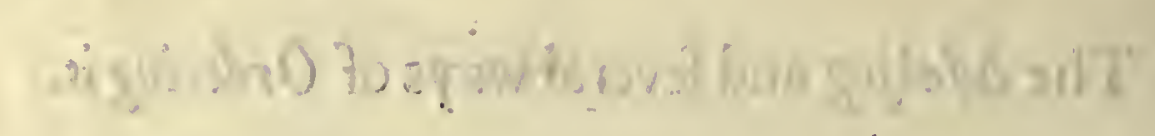

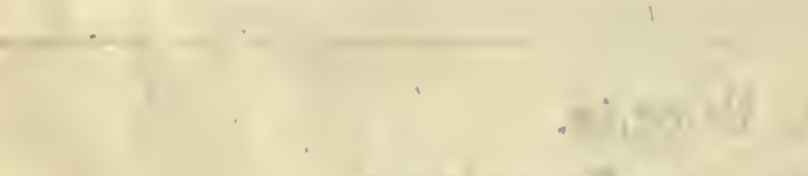

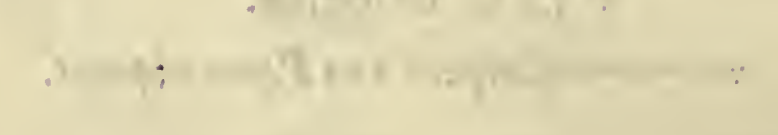

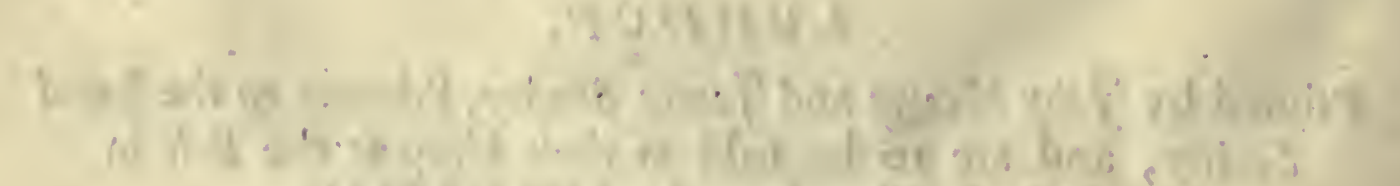

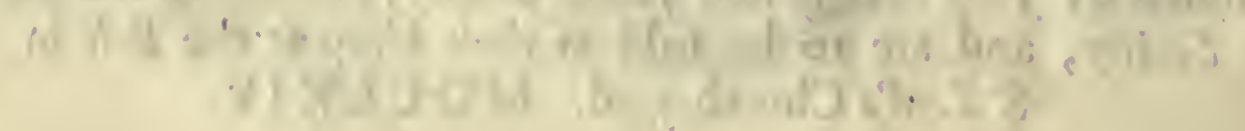


To the Right Honorable

\section{T H
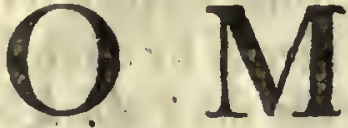 \\ A

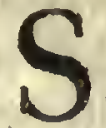 \\ Earl of SOUTHAMPTON,}

Lord HIGH TREASURER

$\mathrm{OF}$

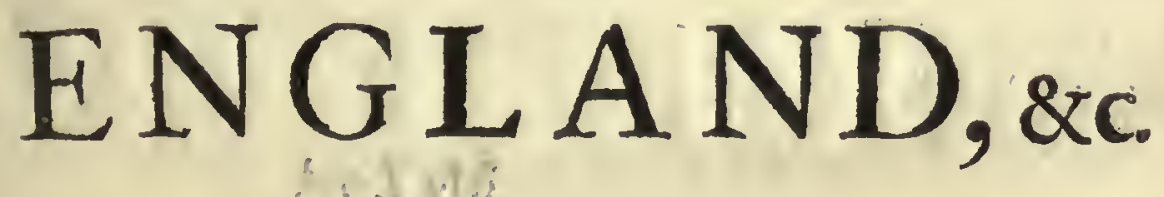

My Lord,

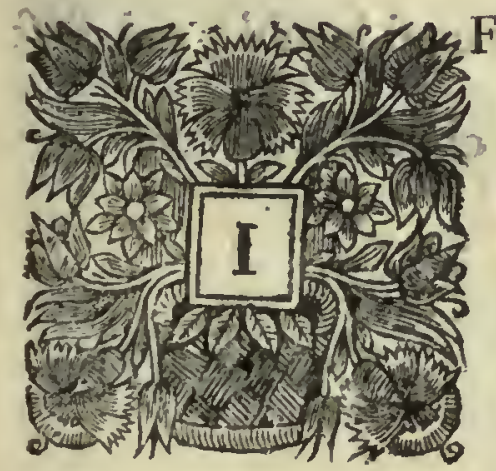

F great Examples did not fupport it, the dignity and greatnefs of your Perfon would foon have given cheque to this prefumption: But fince Emperours and $K$ ings have not only gratefully accepted Works of this nature, but honor'd them likewife with their own facred hands, that Name of yours (which ought indeed never to appear but in Inftruments of State and fronts of Marble, confecrating your Wiflom and Vertues to Eternity) will be no way leffen'd by giving Patronage to the fe appendant Rufticities. It is from the Protection and Cherifhment of fuch as your Lordfbip is, that thefe Endeavours of ours may hope one day to fucceed and be profperous. The nobleft and moft ufcful Structures have laid their Foundations in the Eartb : ' if that prove firme bere (and firme I pronounce it to be, if your Lordf ip favour it) We fhall go on and flourith. I fpeak now in selation to the Royal Society, not my felf, who am bus a Servent of it only, and a Pioner in the Works. But be its fote what it will, Your Lordfjip, who is a Builder, and a lover of ali Niagnificences, cannot be difpleas'd at thefe agreeable Accel- 


\section{The Epifle Dedicatory.}

forles of Planting, and of Gard'ning. But, my Lord, I pretend by it yet fome farther fervice to the State then that of meerly profit, if in contributing to your divertifement I provide for the $P$ ublick bealth, which is fo precious and neceffary, to it in your excellent Perfon. Vouchfafe POMONA your LordßBips hand to kifs, and the humble Prefenter of thefe Papers the honor of being efteem'd;

\section{My Lord,}

Your moit humble, and moft

$$
\text { obedient Servant. }
$$

F. EVELTN. 


\section{P O M O N A;}

Or An Appendix Concerning

F R U I T-T R E E S,

In relation to

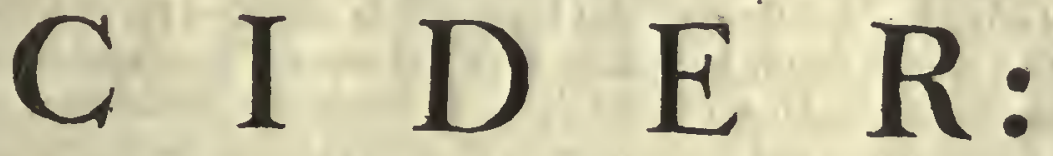

The Making, and feveral ways of Ordering it.

\section{THE PREFACE:}

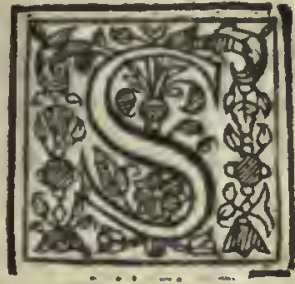

At Quercus was the Proverb; and it is now time to walk Ans dpu' out of the Woods into the Fields a little, and to confi- in eos, qui reder what Advancement may be there likewife made by lidio viliuforthe planting of FR U I T-T REES. For after the dido, ad elew Earth is duly cultivated, and pregnant with a Crop of gantiorem

Grain; it is onely by the Furniture of fich Trees as lautioremgs bear Fruit, that it becomes capable of any farther Im- tur.

provement. If then by difcovering bow this may best be effected I can but raife a worthy emulation in our Countrey-men; this addition of noble Ornament, as well as of Wealth and Pleafure, Food axd Wine, may ( $I$ prefume) obt ain fome grateful admittance amongft all promoters of Induftry.

But before I proceed, I must, and do ingenuouly acknowledge, that I prefent iny Reader bere with z'ery little of my own, fave the pains of collecting and digenting a few dipers'd Notes (but fuch as are to me $c x-$ ceedinglyprecious) which I bave receiv'd; fome, from wortby, and most experienc' $d *$ Friends of mine; and others, from the mell-fur- * Especially; nif ${ }^{3} d$ Regifters, and Cimelia of the ROY A L SOCIETY. from the Eppecially, those Aphorifms, and Treatifes relating to the Hiftory of Cider, whicb by exprefs commands they have been pleas'd to injoyn I fould publifh with my Sylva.

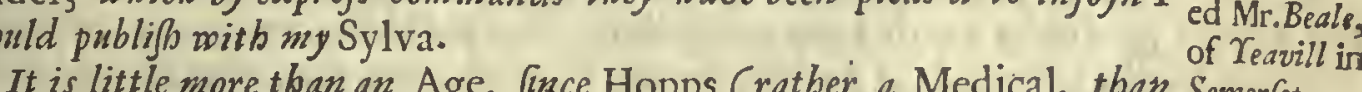
mort excellently learn-

It is little more than an Age, fince Hopps (ratber a Medical, than SomerfetAlimental Vegetable) tranfmuted our wholefome Ale into Beer; which frire, a Memdoubtless much alter'd our Conftitutions: That one Ingredient ( by ber of the fome not unwortbily fupected) pre ferving Drink indecd, and fo by cuftom Royal Socis made agreeable; yet repaying the pleafure with tormenting Difeafes, ety. and a forter life, may defervedly abate our fondnefs to it; efpecially, if with this be confider'd likemife, the cafualties in planting it, as feldom fucceeding more than once in three years; yet requiring conftant charge and culture; Befides that it is none of the least devourers of joung Timber.

And wothat if a like care, or indecd one quarter of it, were (for the future) converted to the propagation of Fruit-trees, in all parts of this Nation, as it is already in fome, for the benefit of Cider? (one Shire 
alone witbin twenty miles compafs, making no lefs, yearly, than Fifty thoilfand Hogheads) the commutation zrould (I perjacide my felf) robus of no great Advantage; but prefent uswith one of the most delicious and wholefome Beverages in the World.

It was by the plain Induftry of one Harris (a Fruiterer to King Henry the Eighth) that the Fields, and Environs of about thirty Towns, in Kent onely, mere planted with Fruit, to the univer $\int a l$ benefit, and general Improvement of that County to this day; as by the noble example of my Lord Scudamor, and of fome other publick.jpirited Gentlemen in thofe parts, all Hereford-1hire is become, in a manner, but one intire Orchard: And when bis Majefty frall once be pleas'd, to command the Planting but. of fome Acres, for the best Cider-fruit, at every of lis Royal Manfions, amongst ot ber of bis most laudable Magnificences; Noblemen, wealthy Purchafers, and Citizens will (doubtlefs) follow the Example, till the preference of Cider, robolefome, and more natiral Drinks, do quite vanquifh Hopps, and banifh all ot ber Drogues of that nature.

But this Improvement (Jay fome) roould be generally obstruifed by the Tenant and High-fhoon-men, who are all for the prefent profit; their expectations feldome holding out above a year or two at most.

To this 'tis anfwer'd; That therefore fould the Lord of the Mannour not onely encourage the Work by his own Example, and by the Applaufe of fuch Tenants as can be courted to delight in the fe kindes of Improvements; but fhould alfo ablige them by Covenants to plant certain Proportions of them, and to preferve them being planted.

To fortifie this profitable Defign, It mere farther to bo delir' $d$, that an Act of Parliament might be procur'd for the setting but of two or threc Trees in every Acre of inclos'd Land, under the Forfeiture of Six-pence per Tree, for fome publick and charitable Work, to be levy d on the Defaulters. 70 mbat an innumerable multitude would this, in fem years, infenflbly mount; affording infinite proportions, and variety of Fruit throiglout the Nation, which now takes a Potion for a refrefonent, and drinks its very Bread-corn!

I lave fecn a Calculation of tmenty Fruit-trees to every Five-pounds of yearly Rent; fourty to Ten; fixty to Fifteen; cigbty to Twenty; and fo according to the proportion. Had all our Commons, and Wafte-lands, one Fruit-tree but at every hundred foot distance, planted, and fenc'd at tbe publickcharge, for the benefit of the Poor, (whatever might dy and mifcarry) enough would efcape able to maintain a Stock, which would afford them a most incredible relief. And the Hedg-rows, and the Champion-grounds, Land-divifions, Mounds, and Head-lands (wobere the Plough not coming, 'tis ever abandon' $d$ to Weeds and Briars) rould add yet confiderably to the ese Advantages, without detriment to any man.

As touching the Species, if much bave been faid to the preference of the Red-ftrake before other Cider-Apples, this is to be added; That as the beft Vines, of richeft liquor, and greateft burden, do not jpend nuch in wood and unprofitable branches; fo nor does this Tree: For though otber Cider may feem more pleafant (fince we decline to give Judgment of what is unknown to ws) we yet attain our purpofe, if This foall appear beft to reward the Planter, of any in prefent practise; efpecially, for the generality; becaufe it woll fit the moft parts mhich are, addicted to thefe Liquors, but mifs of the right. kinds, and prowe the moft fecure from external injuries and Invaders. 
- Not to refine upon the rare effects of Cider, which is abode all the moft eminent, foberly to exhilerate the Spirits of zes Hypochondriacal Iflanders, and by a fpecific quality to chafe away that unfociable Spleén, mitbout excess; the very Bloflome of the Fruit perfumes, and pitrifies the Ambient Air, mbich (as $M$. Beale well obferves in bis Hereford-fhire. Orchards) is conceiv'd conduces fo much to the conftant Health and Longavity, for which that Country his been always celebrated, fencing their Habitations and froet Recefles from Winds, and Winter-inivafions, the beat of the Sun, and bis nifufferable darts: And if ( faith he) Hereford-sin: we may acknowledge grateful trifles, for that they harbour a conitant Orch. p. 8. Aviary of fweet Singer's, which are bere retain'd without the charge of Italian wires: To wbich I cannot but add bis following option, That if at any time we are in danger of being hindred from Trade in Forreign Countries, our Englifh Indignation may fcorn to feed at their Tables, to drink of their Liquors, or otherwife to borrow or buy of Then, or of any their Confederates, fo long as our Native foylé doés fupply us with fuch excellent Neceflarics.

Nor is all this produc'd to redeem the Liquor from the fuperftition, prejudice, and opinions of thofe Men who do fo much wagnific the juice of the Grape above it: If Experiments from undenyable fuccess (in Jpite of Vintners, and Bauds to mens Palats) were (ufficient to convince us; and reclaim the vitiated; or that it mere poljible to dijpute of the pleafantnefs, riches, and precedency of Drinks and Diets, and fo to provide for fit, competent, and impartial Judges; when by Nature, Nation, or Climate (as well as by Cuftom and Education) we differ in thofe Extreans.

Moft parts of Africa, and Afia prefer Coffec before our Nobleft Liquors; India, the Roots and Plants before our beft Cook'd Venifon; Almoft all the world crude water, before our Country Ale and Beer; and we Englifh being generally niore for infipid, lufcious, and grofs Diet, then for the Cpicy, poignant, oylie, and bighly relifh'd, (witnefs our univerfal batred of Oyls, French-wine, or R henilh without Stigar; our doating on Currans, Figgs, Plum-pottage, Pies, Pudding, and Cake) render yet the difficulty more arduous. But to make good tbe Experiment. About thirty years fince one $M$ T aylor (a perfon well known in Hereford-thire) challeng $\bar{d}$ a London-Vintner (finding bin in the Country) That be would produce a Cider wobich frould excel bis beft Spanifh or French-wine: The Wager being depofited, He brings in a good Redfrake to a private Houfe: On that Scenc, all the Vintner could call to be Judgespronounce againft bis Wine; Nor would any man there drivik French-wine (mitbout the belp of Sugar) nor endure Sack for a fill dranght; and to Thofe mho were not aciuftomed to either, the niore racy Canaries mere no more agreeable then Malaga, too lufcious for the repetition.But this Wager being lof?, our Vintner renews bis Chartel, upon thefe expresterms, of Competent and Indifferent Arbitrators: The Gentleman agrees to the Articles; and thus again after mutual engagements it muft be debated who were Competent Judges, and abjolutely Indifferent. $M$ Taylor propojes Three, nhereof the odd Number fiould by Vöte determine: They mult be of the fitteft Ages too, or rather the fitteft of all. Ages, and fuch as were inur'd neitber to Cider nor any Wine; and fo it was agreed. The Jurges convene; viz. A Youth of ten years old, a Man of thirty, and a Third of fixty; and by All thefe alfo our Vintner 
loft the Battcl. But this is not enough; 'Tis affay'd again by Nine Judges, the Ternary thrice over; and there 'tis loft aljo. And bere I will conclude; for I think never was fairer Duel; nar can more be reafonably pretended to vindicate this Blefling of God, and our Native Liquor from their contempt, and to engage our Propagators of it.

Tut veneficiis io fum up all: If Health be more precious then Opinion, I wifh our placere cogi-Admirers of Wines, to the prejudice of Cider, bebeld but the Cheat sur, of miram themfelves ; the Sophiftications, Transformations, Tranfmutations, mur noxium Adulterations, Baftardizings, Brewings, Trickings, and Compaffings efoe Vinsm? Plin. of this Sophifticated God they adore; and that they bad as true an In-
As 'tis moft fpection into thofe Arcana Lucifera, which the Priefts of bis Temples ingeniouly (our Vintners in their Taverns) do practife; and then let them Temples

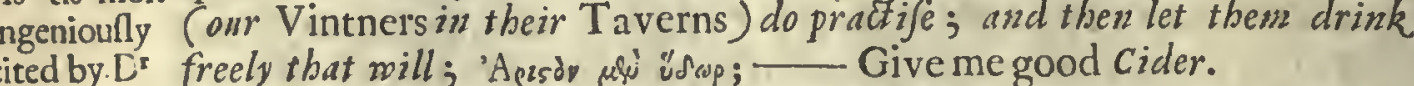
Charleton, in It is noted in our A phorifms bow wuch this Beverage was efteemed by his excellent His late Majefty, and Court, and there referr'd to all the Gentry of the Difcourfe of the Adulte rations of Wine, entered into the Regifter of the Royal Society; and $\mathrm{C}$ (with thore other moft ufeful Pieces fubjoyn'd) worthy to be publihhed. invironing Country, (nostrangers to the beft Wines) when for feveral Summers in the City of Hereford ( $\int 0$ encompa $\beta^{3} d$ mith store of it, and brought thither mithout clarge, or extraordinary lubductions) it was fold for fixpence the Wine-quart, not for the fcarcity, but the excellency of it: And for the Red-ftrake, that it has been feen there bundreds of times (with vebement and engaged competition) compar'd with the Cider of other the moft celebrated Fruit, when after $a$ while of vapour, no Man stood for any otber Liquor in comparifon.

But it is from the fe Inftances (may fome fay) mben the World foall bave multiplied Cider-Trees, that it will be time enongh to give Infructions for the right Preffing, and Preferving of the Liquor. The objeition is fair: But there are alseady more Perfons better furning'd with Fruit, then mith Directions hom to ufe it as they frould; when in plentiful years fo much Cider is impair'd by the ignorant handling, and becomes dead and foror, that many even furfeit with the Bleffing; it being rarely feen in moft Countries, that any remains good, to fupply the deferts of another year; and the Royal Society would prevent all tlis bazard by this free Anticipation.

It now remains, that $I$ flould make fome Apology for my felf, to extenuate the tumultwary Method of the enfwing Periods. Indeed it was not intended for a queint or elaborate piece of Art; nor is it the defign of the Royal Society to accumulate Repetitions when as they can be avoyded; and therefore in an Argument $\int 0$ mucb beaten as is that of drel ing the Seminary, Planting, and modes of Graffing, it bas been with Induftry avoided; juch rude, and imperfect draughts being far better in their eftcem (and according to my Lord Bacon's) then fucb as are adorn'd with more pomp, and oftentous circumftances, for a pretence to Perfection. The time may come when the richners, and fullners of thei Collections may mortbily invite fome more Induftrious Perfon to accomplifh that Hiftory of Agriculture, of which thefe Pieces (like the limbs of Hippolytus) are but fcattered parts: "And it is their greateft ambition for the Publique Good, to provide fuch Materials, as may ferve to Raife, and Beautifie that moft defirable Structure.

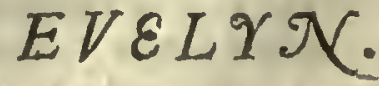




\section{$\mathbf{P}$ M
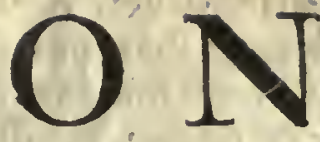 \\ A.}

\section{CHA P. I. \\ Of the Seminary.}

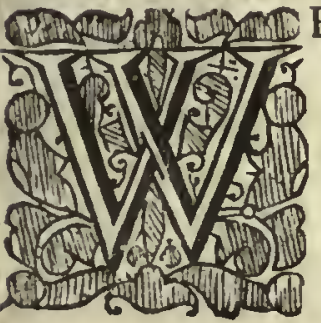

E had not the leaft intention to enlarge upon this Title, after we had well reflected on the many and accurate Directions which are already publifhed, as well in our French-Gardiner, as in fundry other Treatifes of that nature, had not a moft worthy Mrember of the Royal society Mr. Beale of (to whom we have infinite Obligations) fur- Yeavil in nifh'd us with fome things very particular and Somerfetremarkable, in order to the improvement of our seminaries, thire. stocks, \&c. which are indeed the very Bafis and Foundation of Cider-Orchards. It is from thofe precious papers of his, and of fome otbers (whofe Obfervations alfo have richly contributed to Mr. Buckthis Enterprize) that we fhall chiefly entertain our Planter in moft land. of the following Periods.

Whofoever expects from the kernel of a rich or peculiar Apple or Pear to raife Fruit of the fame kind, is likely to find many obftructions and difappointments: For the Wilding, (Crab or Pear) Fomus sylveftris, being at the beft the natural product of the foundeft kernel in the firment land, and therefore the guft of the Fruis more ftrongly auftere, fierce, and tharp, and alfo the Fruit lets and more woody; and the pleafanter or plumper and larger Apple being the effect of fome inteneration, which inclines to a kind of rebatement of the natural ftrength of the Tree; the beft choice of kernels for stocks indefinitely, (and on which we may graff what we pleafe) (hould be from the foundeft wilding. . For,

A kernel taken from any graffed-Apple, as Pepin, Pear-main, \&c. does moft naturally propend to the wildnefs of the stock on which 'twas inferted, as being the natural mother of the kernel, which is the very heart of the Apple; and alfo from a more deep and fecret Reafon, to be hereafter unfolded.

Apples and Pears requiring rather a vulgar and ordinary Fieldland, then a rich Garden-mould, (as has been often extracted by frequent Obfervations) it has been found that kernels fowed in a very high compoft, and rank earth, have produced (large indeed) but infipid Fruit, haftily rotting on the Trees, before all the parts of it were mature. Vid. Aphor. 33 .

And fometimes when they feemed in outward figure to bear the Thape of graffed Apples, from whence the kernels came, yet the guft did utterly deceive, wanting that vivacity and pungent agreeablenefs. 
If the kernels of natural Apples (or of ungraffed Trees) fhould produce the fame, or fome other variety of Apples, (as fometimes it fucceeds) yet.would this care be feldom opere pretium, and at beft but a work of Cbance, the difappointment falling out fo often through the ficklenefs of the Soil: Or admit that the moft proper and conttant, yet would the very dews and rain, by various and mutable Seafons, and even by the Air it felf, (which operates beyond vulgar perception, in the very changes as well of the mould, as of the feeds and fruit) create almoft infinite alterations: And the choice having been in all places (apparently for fome thoufands of years) by propagating the molt delicate of Fruits by the Graffs, 'tis almoft a defperate task to attempt the raifing of the like, or better Fruit froin the rudiments of the Kernel.

Yet fince our defign of relieving the want of Wine, by a succedaneuin of Cider, (as lately improv'd) is a kind of Modern Invention, We may encourage and commend their patience and diligence who endeavour to raife feveral kinds of Wildings for the tryal of that excellent Liquor; efpecially fince by late experience we have found, that Wildings are the more proper Cider-Fruits; fome of them growing more fpeedily, bearing fooner, more conftantly, and in greäter abundance in leaner Land, much fuller of juice, and that more mafculine, and of a more Winy vigour.

Thus the famous Red-ftrake of Hereford-foire is a pure Wilding, and within the memory of fome now living firnamed the scudamores $\mathrm{Crab}$, and then not much known fave in the Neigbbourbood, \& $\mathrm{xc}$. Yet now it would be difficult to thew that Red-ftrake which grew from a kernel in that whole Tract, all being fince become graffed Tree's. Thus tis alfo believed, That the Blomsbery Crab (which carries the fame in fome parts of Glocefter-fire) and many of the White $M u f t_{s}$, and Green $M u f t_{s}$, are originally savages; as now in somerfct-jhire they have a generous Cider made of promifcuous kernels, or ungraffed Trees, which fills their confidence that no other Cider does exceed it; and 'tis indeed frong, and fufficiently heady.

Nor dare we pofitively deny, but that even the beft of our $\tau_{a}$ ble-fruit came alfo originally from the kernel: For though it be truly noted by my L. Bacon, That the Fruit does generally obey the Graff, and yields very little to the Stock; yet fome little it does.

The famous Bezy de Hery, an excellent Musky Pear, was brought into the beft Orchards of France from a Foreft in Bretainy, where it grew wild, and was but of late taken notice of.

But now to the deep Reafon we lately threatned: We have by an Experiment found fome neer affinity between the Kernel of the Apple and the beart or interiour of the stock: For I faw (fays $\mathbf{M}^{\mathrm{r}}$ Beale) an old rotten Kernel-Tree bearing a delicate Summer-fruit, yielding store of fnooth Cider, ('tis call' $d$ the French-Kernel-Tree, and is alfo a Dwarf, as is the Red-ftrake; ) and examining diver's Kerncls, many years Juccelfively, of that bollow and decayed Tree, $I$ found them always very jmall of growth, and empty, meer skins of Kernels, not unlike to the emafculated Scrotum of in. Eunuch; ano. 
Or, An Appendix concer ning Fruit-Trees, ¿ov.

ther younger Tree, iffuing from the founder part of a Root of the fame old Tree, had fiull and entire Kernels.

And from fome fuch Obfervation might the production of Berberies, \&c. without stones, be happily attempted; in Inftrumènt fitted to takc out the marrom or pith of the Branches, (as the fame Mr Beale perform'd them; ) for from the mumerical Buth of that Frrit he found fome Branches produce Berberies that had no ftones, otber's which had; and in fearching for the canfe of the effect, perceived, that the pith or heart was taken from the radicat, or main Branches, as the other was full of pith, and confequently the fruit in perfection; of all which(he writes me word) he made feveral tryals on other fruit, but left the place before he could fee the event. But he adds;

Thefe many years (almoft twenty) I bave yearly tri'd Kernels in Bedds of clean Earth, Pots and Pans, and by the very leaves (as they appear'd in firft jpringing for one moneth) I could difcern bow far my Ellays bad civiliz'd 'cm: : The Wilder had fhorter, ftiffer, brown, or fox-colour'd leaves: The more ingenuous bad more tender, more preading leaves, and approaching the lighter verdure of the Berbery leaf when it firft appears. He adds,

some Apples are call'd Rofe-Apples, Rofemary-Apples, Gillyflower-Apples, Orange-Apples, with feveràl otber adjuncts, denominating them, from what Reafon $I$ know not. But if we intended to try fuch infufions upon the Kernels (as hould endeavour to alter their kinds) we thould not approve of the bedabbling them with fuch infufions, (for over-moifture would rather enervate then ftrengthen thein) but rather prepare the Earth the year before, with fuch infuccations, and then hinder it from producing any Weeds, till ready for the Kernels, and then in dewy times, and more frequently when our Climate were furcharg'd with rain, cover the Beds and Pots with the fmall leaves of Rofemary, Gillyflowers, or other oderiferous Blofjomes, and repeat it often, to the end the dews may meteorize, and draw forth their finer spirits, \&c. And thus alfo we are in this Age of ours provided of more vigorous Ingredients for trials then were known to the Ancients. Finally,

From what has been deduc'd from the Wilding of feveral parts, it may manifeftly appear, how much more congeneal fome foil is then other, to yield the beft Cider-fruit from the Kernel; and the bazzle ground, or quicker mould, much better then the more obfinateclay or ranker earth.

\section{CHA P. II.}

\section{of Stocks.}

THe former thus eftablifh'd, after all bumours and varieties have been fufficiently wearied, we thall find the Wilding to be the hardieft and moft proper Stock for the moft delicate Fruit: 
This confirm'd by Varro, lib. I. cap. 40. In quaincungue arborem in Seras, \&xc. and 'tis with reafon: However they do in Heiefordfoire, both in practice, and opinion, limit this Rule; and to preferve the guft of any delicate Apple (as of the Tear-main, 2uince-Apple, Stockin, \&c.) rather graff upon a Gennet Moyle or Cyder stock; (as there call'd) then a Crab-ftock; but then indeed they conclude the Tree lafts not fo long; and 'tis obferv'd, That Apples are better ta' fted from a clean, light land, \& c. then from ttiffer clay of the more pinguid and luxurious foil.

Thus in like manner our Mafter Varro, loco citato concerning pears; Si in Pyrum sylvaticam, \&c. The Wild-ftock does enliven the dull and phlegmatic Apple, and the Stock of a Geninet-Moyle fweeten and improve the Pepin, \& c. or may rather feem to abate at leaft fome Apple over-tart and fevere.

Your Crab-ftock would be planted about odfober, at thirty two Foot diftance, and not graffed till the third spring after; or at leaft, not before the fecond.

But if your defign be for Orchard only, and where they are to abide, an interval of fixteen Foot mall fuffice, provided the ground be yearly turn'd up with the space, and the diftance quadrupled where the Plough has priviledge; this being the moft expedite for fuch as have no Nurfery ground.

Crab-ftocks are better then Sets of Apple Kernels to graff on; becaufe they impart a more juicy and tart relifh; and fo are to be preferred for môt forts of Apples.

\section{CHAP. III.}

\section{of Grafts and Infitions.}

\section{Ake choice of your Graffs from a conftant and well-bearing Branch.}

And asthe stock hath a more verdant rind, and is capable to yield more plenty of juice, fo let the Graff have more Eyes or Buidds: Ordinarily three or four Eyes are fufficient to give iffue to the Sap; but as well in Apples, and Pears, as in'Vines, thofe Graffs or Cions are preferr'd in which the budds are not too far afunder, or diftant from the foot thereof: And fuch a number of buds ufually determining the length of the Graff, there may divers $\mathrm{Ci}$ ons be made of one Branch, where you cannot procure plenty of them for feverals.

As to the fuccefs of graffing, the main skill is, to joyn the inward part of the Cion to the fappy part of the stock, clofely, but not too forceably; that being the beft and moft infallible way, by which moft of the quick and juicy parts are mutually united, efpecially towards the bottome.

If the stock be fo big as to endanger the pinching of your Graff, when 


\section{Or, An Appendix concerining Fruit-Trees, \&c.}

when the zpedge is drawn out of the cleft, let the inner fide of the Graff; which is within the wood of the stock, be left the thicker, that fo the rooody part of the Cion may bear the ftrefs, and the Jappy part be preferved from bruifing.

Choofe the frreighteft and fmootheft part of the stock for the place where you intend to graff: If the stock be all knotty (which fome efteem no impediment) or crooked, rectifie it with the fitteft poiture of the Graff.

For a Graff covet not a Cions too Alender; for the sus and $i$ ind will fooner enforce it to wither: Yet are we to diftinguilh, that for Inoculation we take the Bud from a fprig of the laft years Thoot; and moft allow that the Cions thould alfo have fome of the former with it, that it may be the ftronger to graff; and abide to be put clofe into the stock, which is thought to advance it in bearing.

In Hereford-Jhire they do frequently choofe a Graff of feveral years growth; and for the graffing of fuch large stocks as are taken out of the Woods or Nurferies, and fitted into rows for Orchards. they choofe not the Graffs. fo finall as in other Countries they require them; which has, it feems, occafion'd fome complaint from them that underftand not the Reafon of the firft branch of this Note. - Once for all, The ftumpy Graff will be found much fuperiour to the flender one, and make a much nobler and larger Shoot. This upon experience.

Graff your Cions on that fide of the stock where it may receive the leaft hurt from the south-meft Wind, it being the moft common, and moft violent that blows in summer; fo as the wind may blow it to the stock, not from it: And when the Zephyres of the spring are firring, choofe that seafoin before all others for this work.

Some there are who talk of removing the stock about Chriftmas, and then alfo graff it; which there be that glory they can fucceffully do even by the fire fide, and fo not be forc'd to expect a two or three years rooting of the stock; But in this Adventure 'tis advifeable to plunge the Graff three or four inches deep in the stock: Laft]y,

Be careful that the Rdin get not into the clefts of your young graffed stocks: Yet it has been noted, That many old Trees (quite decay'd with an inward hollownefs) have born as full burdens; and conftantly, as the very foundert, and the Fruit found to be more delicate then ufually the fame kind from a perfect and more entire Stock.

Except fome former cafe requires it, leave not your Graffs above four, five, or (at moft) fix inches of length above the stock; for by the length it draws mote feebly, and is more expos do the thocks of the Wind, or hurt by the Birds; and you fhall frequentIy perceive the fummities and tops of fuch young Graffs to be mortified and die.

Now for encouragment in trañfporting Griffs àt great diftance, we find that with little care (their tops uncut and unbruis'd) they 
will hold good, and may fupport the tranfportation by sea or Land from october or November to the very end of March.: See Sir H. rlat's Offers, Paragr. 75. To which may be added, That if the Graff receives no hurt by lying in the Stock cxpos'd to all rain, dews, and réverities of Winter, frolts from December. to spring, (as has been experimentally noted); then (by a ftronger prefumption) in oyled, or rather waxen Leather, it may undoubtedly efcape. Some prefcribe, That the ends thall be fuck in a Turnip: And many excellent Graffers (Gentlemen fome of very good credit) have aflured us, That the Graffs which feemed withered, and fit to be caft away, have proved the beft when tri'd. Thus in honeft Barnaby Googes noble Heresbachizs you will finde it commended to gather your Cions in the mane of the Moon, at leaft ten days before you graff them; and conftantine gives this realon for, it, That the Graff a little withered, and thirfty, may be the better received of the stock: There are alfo other induccments for this practice, as simon Harwood, pag. 4. has thew'd us; but none beyond our own experience, who have known Graffs gathered in December thrive and do perfectly well.

\section{CHAP. IV.}

\section{of Variety and Improvements.}

T $F$ any man would have variety of unexpected and unknown Apples and .Pears, for the improvement of Cider, or Palatefruit, thore is more hope from Kernels rais'd in the Nurfery (as has already been directed) then from fuch tryals of graffings as we have yet feen in prefent ufe.

But if we would recover the patience, and the fedulity of the Antient (of which fome brief account will follow) or liften to fome unufual Propofals, then may we undertake for fome variety by Infitions.

To delude none with promifes, we do much rather recommend the diligence of inquiring from all Countries the beft Graffs of fuch Fruits as are already found excellent for the purpofe we defign: As from the Turgovians for that Pear of which Mr. Pell gives fo good and weighty informations.

But as fome forts are to be inquired after for the Palate and the Table, fo'tis now our main bufinels to fearch after fuch as are excellent for their Liquor, either as more pleafant, more winy, or more lafting; of which fort the Bosbury bare-land-Pear excels. The Red-jtrake, Bromebury-Crab, and that other much celebrated Wilding call'd the Oaken-pin, as the beft for Cider; though for fufficient reafons none of them comparable to the Red-ftrake.

But to purfue the diligence of the Antients, we direct the eye to a general expedient for all kinde of varieties imaginable, and 
which we hold far better then to prefent the World with a $L$ ift of the particulars either known, or experimented: For who indeed but a Fool will dare to tell Wonders in this fevere Age, and upon an Argument which is fo environ'd with Impofture in moft Writers; old or new! Much lefs pretend to Experiments which may fail to fucceed by default of a happy Agent, when the conclufion muft be, Penes Authorem fit fides!

And truly men receive no fmall difcouragement from the ugly affronts of clowns, and lefs cultivated perfons; who laugh and fcorn at every thing which is above their underftanding: For example; I knew a man (writes Mr. Beale to me) and be a moft diligent Planter and Graffer, who for thirty or fourty years made innumerable Effays to produce fome change of an Apple by graffing : It feems be . was ambitious to leave bis Name on fuch a Fruit, if he could bave. obtain'd it; but always fail'd; for be perpetually made bis Trials upon Crab-ftocks, or fuch (at leaft) as did not greatly differ from the kind; and he ever found that the Graff would predominate. And how infinitely fuch Men having loft their own aims, will defpire better Advice, we leave to obfervation.

However, let us add, That. where nothing is more facile then to raife new kinds of Apples (in infinitum) from Kernels: Yet in that Apple-Country (fo much addicted to orchards) we could never encounter more then two or three perfons that did believe it: But in other places we meet with many that, on the other fide, repute Wildings, or (as they call them) Kernel-fruit, at all adventure, and without choice, to be the very beft of Cider-fruit, and to make the moft noble Liquor. So much does the common judgment differ in feveral Countries, though at no confiderable diftance, even in matters of vifible Fact, and epidemical experience.

It was our excellent Friend Mr. Buckland who fent us word of one in somerfet-fhire, who by graffing any White Apple upon an Elma changes the Apple, and particularly to a red colour: He directs us where we may be eye-witneffes of the proof, and alfo to a Clergyman hard by, wholoft his labour in the fame Attempt, by the perifhing of the Graffs; fo as by his Advice we are not over-haftily to erect Hercules's Pillars; and renders his Reafons, encouraging our Experiments.

-To gratifie yet the Ingenious, infruct others, and emancipate us all from thefe-baftinado-Clowns, we are furnifh'd with many $A r-$ guments and proofs to affure a good fuccefs, at leaft for variety and cbange, if not for infinite choice: Two or three antient References being duly præmis'd; namely; Firft,

I. That 'tis in vain to expect change of Apples from graffing upon differing stocks of Crabs, or Apples.

2. In vain alfo are we to look for a kind $T$ ree from a very much differing Stock; as an altered Pear to grow kindly on a Crab or $\mathrm{Ap}$ ple-jtock, \& contra. There go about indeed fome jugglings, but we difdain to name them.

It is one thing to finde the kindeft stock for the Improvement of any Fruit; as the Crab-ftock for the delicate Apple, the Wild or 
Black-Cherry-Stock, tor the graffs of the faireft Cberries; the larget Vine, (whole root makes beft thift for relief) to accept the Graff of the more delicate Vine, \&c. And another thing it is to feek the stock which begets the wonder, variety, and that fame tranfeendent and particular excellency we inquire after : For this muft be at more remote diftance; and we offer from the Ancients to fhew, how it may be at any diftance whatfoever: But this is falved by Sir H. Plat's expedient, Paragr. 72. viz. If two Trees grom together, that be apt to be graffed one into anotber, then let one branch into another, morkmanly joyning sap to Sap. This our Gardiners call Graffing by Approach.

But in this Rule he is too narrow for our purpofe, and far thort of old experience: As alfo in Parag.63. Where he affirms, We may not graff a contrary Fruit thereon. Againft this we urge; That any contrary Fruit may be adventured, and any Fruit upon any fruitlefs stock growing neer in the fame Nurfery: If it be not only affirm'd, but ferioully undertaken, and experimentally proved by the fober Columella, in feveral of his Trearifes; Turn to the eleventh Chapter of his fifth Book, (stephens Edition:) Sed cum An tiqui negaverint pojje oinne gexius furculorum in omnem Arborem inSeri, \&illam quali finitionem, qua nos paulo ante ufi fumus, veluti quandam legem fanxerint, eos tantim jurculos poffe coalefcere, qui fint cortice, ac libro, \& frudu confimiles its arboribus quibus injeruntur, exiftimavimus crrorem bujus opinionis difcutiendum, tradendàmque pofteris rationem, qua polfit omne genus furculiomnigeneri Arboris inferi. And the example follows in a Graff of an olive into a Fig-ftock by Approach (as we callit,) which he alfo repeates in the twenty feventh Chapter of his Book De Arboribus, without altering a fyllable: But poffibly in this cbeck at the Ancient he might aim at old Varro, whom we finde threatning no lefs then Thunderbolts and Blafts to thofe who fhould attempt thefe Itrange Marriages, and did not fort the Graff with the Iree; confult lib. 1. cap. 40. Bu thus you fee this Art aftum'd by Columella for his own invention ( 1500 years fince) to be no news to Varro 200 years older; where he goes on, Eft altcra pecies ex arbore in arborem infercndi nuper animadverfa in arboribus propinquis, Sxc. Though here again we may queftion our Mafters nuper animadverfa too ; fince before he was born $C$ ato relates it as ufual to Graff Vines in the manner by them prefcribed, cap. 4I. Tertia infitio eft: Terebra vitem quam inferes, \&c. Which makes us admire how the witty Walchius in his Difcourfe De vitzbus fructuarits, pag. 265. could recount the graffing of Vines amongt the wonders of Modern Inventions.

But it feems Varro and his Contemporaries did extend the practice beyond Cato; and Columella proceeded further then Varro, even to all forts of Trees, however differing in nature, quality, barke, or feafon: And then Palladius affumes the refult, and gives us the particulars of the fuccels in his Poem, De Infitionibus. And to thefe four as in chief (no phantaftical or counterfeit perfons) we refer the Induftrious. 
But be pleas'd to take this note alfo : As foon as your Graff hath prepar'd a second, or at fartheft a third years growth, take it off the Stock; and then graff it upon a stock of a more natural kind: For in our own Trials we have found a graff profper the fecond year exceeding well; $;$ yet the third the whole grow th at once blafted quite to the very'stock, as if Varro's Augurs had faid the word.

To this add, the making ufe of fuch stocks as in this Experiment may contribute fome fpecial aid to feveral kinds of humane Infirmities: As fuppofe the Birch Tree for the Stone, the Elm for Fevers, \&c.

Moreover, To graff rather the Wilding, or Crab, then the Pepin, becaufe the Wilding is the more natural; and Nature does more delight in progrefs, then to be Retrograde and go backwards.

I thould alfo expect far more advance from a more pungent Sap, then from Infipid; as generally we fee the beft and vigorous juices to falute our Palats with a more agreeable piquancy and tartnefs; for fo we find the rellith of the Stocking-Apple, Golden Pepin, Pearmain, Eliot, Harvy, and all (but Rufjetings and Greenings) to be more poignant then of others.

But we muft note from Palladiws, That the Ancients had the fuccefs which we all; and particularly Sir $\boldsymbol{H}$. Plat does fo frequently deny, as in the particular of graffing the Apple on the Pear, of contra. Let us hear him de Pomo.

\section{Infit a proceris pergit concrefcere ramis, Et focianz mut at malus anica Pyrum: Séque feros fylvis hortatur linquere mores, Et partu gaudet nobiliore frui.}

Pallad. de Infitionib. lib.14.

And this will thew us, That Virgil, and Columella, in feveral of his wonderfull Relations of thefe kinds of mixture, (which but for the prolixity we might now recite) did not fo far effect Wonders as to defert the truth.

You may alfo obferve, That as well the French Gardiner, and our Modern Planters, have found more benefit from the stock of the Quince then old Palladius did, it feems, difcern.

Cum proftet cunctis fe fulva cydonia pomis, Alterius nullo creditur bojpitio.

Roboris externi librum appernata Juperbit, scit tantum inullo crejcere poffe decus.

sed proprizs pandens cognat a cubilia ranis; Stat, contenta Junm nobilitare bonum.

Pallad: de Malo Cydonio.

Laftly, We did by unexpected chance find the facility of graffing the very youngeft stocks, even of one years growth, by the Root: At a fecond removal of the stocks (being then of two years 
growth) we obferved fome Roots fo faft clofed together into one, as not to be divorced: Hereupon we concluded, If cafualty, or negligence, chance of fpade, or oppreffion of neighbourhood did this, by Art it might be done more effectually, and poffibly to fome defirable purpole; for that then the stock was more apt to receive a maftering Imprel/5ion; and any Garden Plant whatfoever might by this proceß interchange and mingle their Roots.

And thus we have prefented our diligent Ciderift with what $\mathrm{Ob}$ fervations and Arguments of Encouragement, grounded on frequent Experience, we have received from our moft ingenious Correpondents, efpecially the Learned and truly Candid Mr Beale, in whofe Perfon we have fo long entertain'd you: And to thefe we could add fundry others, were it not now time (whiles we difcourfe of polfibilities) to conclude with fomething certain, and to fpeak of what we have.

For the kinds then of Cider-Apples in being; Glocefter-fhire affects the Bromsbury Crab; It affords a fmart, winy Liquor, and is peculiarly hardy, but not fo proper for a cold and late-bearing climate, it being not ripe in hot Land till the end of Autumm, nor fit to be ground for Cider till chriftmas, lying fo long in heaps and preparation.

- It is in the fame shire that they likewife much efteem of the white and red Muft-Apple, the fweeteft as well as fowreft Pepin, and the Harvy-Apple, which (being boyl'd) fome prefer to the very beft of all ciders.

But about London, and the more Southern Tracts, the Pepin, and efpecially the Golden, is efteemed for the making of the moft delicious of that Liquor, moft wholefom, and moft reftorative; and indeed it may (in my poor judgment) challenge thofe perfections with very good reafon.

By others the Pearmain alone is thought to come in competition with the beft; but the Cider is for the moft part found of the weakeft, unlefs encourag'd with fome agreeable Pepin to infpirit it. Some commend the Fox-Whelp; and the Gennet-Moyle was once preferr'd to the very Red-ftrake, and before the Bromsbury-Crab; but upon more mature confideration, the very Criticks themfelves now Recant, as being too effeminate and foft for a judicious Palate.

The Redfrake then amongft thefe accurate Tafters hath obtained the abfolute praeminence of all other Cider-fruit, efpecially in Hereford-Sire, as being the richeft and moft vinous Liquor, and See Aph. 42. now with the more earneftnefs commended to our practice, for 45.37. its celerity in becoming an orchard, being ordinarily as full of Fruit at ten years growth as other Trees are at twenty; the Pepin or Tearmain at thirty: And laftly, from that no contemptible quality, That 'tis fo wicked a Fruit upon the T'ree as needs no Priapus for protector, fince (as beautiful as 'tis to the eye) it has fo curfed a tafte in the Mouth till it be converted into Cider.

In fum, The Red-ftrake will at three years graffing give you'fair hopes, and laft almolt an hundred years: And the Gennet-Moyles 
haften to an Orchard for Cider without trouble of Art or Graffing:

But note, That this Tree is very apt to contract a bur-knot neer See. C. Tay: its Trunk, where it begins to divide; and being cut off under that $b o \int s$, commonly grows (if fo fet) and becomes fpeedily a der.

Tree, except it encounter an extraordinary dry summer the firft year to give it check. And though the knack of graffing be fo obvious, yet this more appearing facility does fo pleafe the lazy. Clowns, that in fome places they neither have nor defire any other orchards; and how this humour prevails you may perceive by the hafty progrefs of our Kentifh Codlin in moft parts of England:

But to advance again our Red-ftrake, even above the Pepin, and the reft (befides the celerity of the improvernent and conftant burthen) confider we the moft incredible product, fince we may expect from each Apple more then double the quantity; fo as in the fame Orchard, under the fame culture, thirty Red-ftrake Trees thall at ten years graffing yield more Cider then a bundred of thofe $P e^{-}$ pins, and furmount them in proportion during their period at leaft fixty or feventy years: So that granting the Cider of the GoldenPepin thould excel, (which with fome is precarious) yet 'tis in no wile proper for a Cider-Orchard, according to our general defign, not by half fo foon bearing, nor fo conftantly, nor in that quantity, nor fulnefs or fecurity.

Concerning Perry, the Horfe-Pear and Bare-land-Pear are reputed of the beft, as bearing almoft their weight of fpriteful and vinous Liquor. The Experienced prefer the tawny or ruddy fort, Aph. 43. as the colour of all other moft proper for Perry: They will grow Aph. 34. in common-fields, gravelly, wild, and ftony ground, to that largenefs, as one only Tree has been ufually known to make three or four Hogfheads : That of Bosbury, and fome others, are fo tart and harlh that there is nothing more fafe from plunder, when even a swine will not take them in his mouth. But thus likewife would the abundance preferve thefe Fruits, as we fee it does in Normandy.

\section{CHAP. V.}

\section{Of the Place and Order.}

W JE do ferioully prefer a very wild orchard, as mainly intend$\checkmark$ ed for the publick utility, and to our purpofe of obliging the People, as with a fpeedy Plantation yielding ftore for Cider: Upon this it is that we do fo frequently inculcate, how well they thrive upon Arable, whiles the continuing it fo accelerates the growth in almoft half the time: And if the Arable can be fo levell'd, (as commonly we fee it for Barly-land) then without detriment it may affume the Ornament of cyrws, and flourifh in the 2uincunx.

If it be frallow Land, or muft be rais'd with high Ridges, then $\mathrm{C}_{2}$ 'tis 
'tis neceflary to have more regard of planting on the tops of thofe cminencies, and to excufe the unavoydable breach of the decryfis, as my Lord Verulam excufeth the defect of our humane phanfies in the Conftellations, which obey the Omnipotent order rather then ours: Add to this the rigour of the Royal society, which approves more of plaimmess and uefulness, then of nicene $\int_{s}$ and curiofity; whiles many putting themielves to the vaft chagre of levelling their grounds, oftentimes make them but the worfe; fince where the places are full of gaftly inequalities, there may be planted fome forts of Cider-Fruit, which is apt by the great burden to be prefs'd down to the ground, and there (whiles it hides Irregularities) to bear much better, and abundantly beyond belief; for fo have been feen many fuch recumbent Pear-trees bear each of them tmo, three, yea, even to fix or more Hogßheads yearly.

And for this Cider, whiles we prefer fome forts of Wildings which do not tempt the palate of a Thief, by the caution we fhall not provoke any man to repent his charge from the neceffity of richer and more referv'd Enclofures; Though we have frequently feen divers Orchards fuccesfully planted on very poor Arable, and even in tony Gleab, gravel, and clay, and that pretty high, on the fides and declivities of Hills, where it only bears very thort grafs, like to the moft ordinary Common, not worth the charge of Tillage: And yet even there the Tenants and Confiners fometimes enclofe it for the Fruit, and find their reward, though not equally to fuch orchards as are planted on better ground, and in the Vallies. Hence we fuggeft, That if there be no statute for it, 'twere to be withed there were a $L_{a}$ which thould allow endeavours of this nature out of the Common-field, to enclofe for thefe Encouragements, fince both the Publick and the Poor (whatever the clamour is) are advantaged by fuch Enclofures, as Tuffer in his old Rhimes; and all indifferent obfervers apprehend, with good reafon.

True indeed it is, That all Land is not fit for Orcharding, fo as. even where to form juft Inclofures, being either too $\$$ hallow and $d r y$, or too wet and fterving: But this (faith the judicious $\mathrm{M}^{\mathrm{r}}$ Buckland) we may aver, That there are few Parihes or Hamlets in England where there are not fome fat and deep Headlands capable of Rows of Trees; and that (as hath been faid) the raifed Banks of all Inclofures generally by the advantage of the depth, fatne $s$, and bealth of their Mould, yield ready opportunitie for planting; (yea; and in many Countries multitudes of Crab-ftocks fit to be graffed; ) in which latter" (faith he) I bave frequently obferved very goodly Fruit-bearing Trees, when in the fame foil Trees in Orchards bave been poor and worth nothing. To conclude,

If the foil be very bad and unkind, any other Frit (which it may more freely yield without requiring much depth, and lefs sun) may be planted in ftead of Apples.

CHAP. VI. 


\section{CHAP. VI.}

\section{of Tranfplanting, and Diftance.}

$T$ He mont proper feafon for Tranßplanting is before the hard frofts of Winter furprize you, and that is a competent while before Chriftmas: And the main point is, to fee that the Roots be larger then the Head; and the more ways that extends the better and firmer.

If the stock feems able to ftand on its own three or four legs (as we may call $\mathrm{em}$ ), and then after fettlement fome ftones be heaped or laid about it, as it were gently wedging it faft, and fafe from winds, (which ftones may after the fecond or third year be removed) it will falve from the main danger: For if the Roots be much thaken the firft spring, it will hardly recover it.

You may tranfplant a Fruit-Tree almoft at any tolerable feafon of the rear, efpecially if you apprehend it may be fpent before you have finifh'd your work, having many to remove: Thus let your Trees be taken up about Allballontide, (or as foon as the leaf begins to fall); then having trimm'd and quickned the Roots, fet them in a Pit, fourty, fifty, or a hundred together, yet fo as they may be cover"d with mould, and kept very freth: By the spring they will be found well cured of their movinds, and fo ready to frike root and put forth, that being Tranßlanted where they are to ftand, they will take fuddenly, and feldom fail s whereas being thus cut at spring, they recover with greater hazard.

The very Roots of Trees planted in the ground, and buried within a quarter of an Inch, or little more, of the level of the Bed, will fprout, and grow to be very good stocks. This and the other being Experiments of our own,we thought convenient to mention.

By the oft removal of a Wild-ftock, curting the ends of the Roots, and dif-branching fomewhat of the Head at every change of place, it will greatly abate of its natural wildne $\int$, and in time bring forth nore civil and ingenuous Fruit: Thus Gillyflowers do (by oft removals, and at full-Moon efpecially) increafe and multiply the leaves,

Plant not too deep; for the over-turf is always richer then the next Mould. How material it is to keep the coaft or fide of the stock, as well in Fruit-trees as in Foreft, we have fufficiently difculs'd; nor is the Negative to be prov'd.

For the diftance in Fields, they may be fet from thirty two to fixty See Aph. 35. Foot, fo as not to hinder the Plough, nor the benefit of manure and foil; but in hedg-rows as much nearer as you pleafe, Sun and Air confidered. 


\section{CHAP. VII.}

\section{of the Fencing.}

Eeing a Cider-Orchard is but a wild Plantation, beft in Arable $S$ well enclos'd from Beafts, and yet better on the Tops, Ridges, and natural Inequalities, (though with fome lofs of Order, as we (thew ${ }^{\prime} \mathrm{d}_{3}$ ) one of the greateft difcouragements is the preferving of our Trees being planted, the raifing of them fo familiar.

We have in our sylva treated in particular of this, as of one of the moft material obftacles; wherein yet we did purpofely omit one Expedient, which came then to our hands from the very Induftrious Mr. Buckland to the Learned Mr. Beal: You fhall have it in his own words.

This of Fencing fingle Trees ufeth to be done by Rails at great charges; or by Hedges and Bufhes, which every other year muft be renem' $d$, and the materials not to be had in all places neither. I therefore prefer. and commend to you the enfuing form of Planting and Fencing, which is more cheap and eafic, and which bath other Advantages in it, and not commonly known. I never faw it but once, and that imperfectly perform'd; but have practis'd it my felf with fuccefs: Take it thus.

Set your Tree on the Green-fwarth, or five or fix inches under it if the foil be very bealthy; if moift or weeping, balf a foot above it; then cut a Trench round that Tree, two foot or. more in the cleare from it: Lay a rank of the Turfs, with the grafs outward, upon the inner fide of the Trench towards your Plant, and then a fecond rank mpon the former, and fo a third, and fourth, all orderly plac'd, (as in a Fortification) and leaning towards the Tree, after the form of a Pyramide, or larger Hop-hill: Always as you place a rom of Turfs in compass, you muft fill up the inner part of the Circle woith the loofe Earth of the fecond fit wobich you dig out of your Trench, and which is to be two foot and half wide, or more, as you defire to mount the hillock, which by this means you will bave rais'd about your Plant near three foot in beighth. At the point it needs not be above two foot or eighteen inches diametre, where you may leave the Earth is form of a Dilh, to convey the Rain towards the body of the Tree; and upon the top of this hillock prick up five or fix fimall Briars or Thorns, binding them lightly to the body of the Plant, and you bave finifh'd the work.

The commodities of this kind of Planting are,

Firnt, Neither Swine, nor Sheep, nor any other fort of Cattel can annoy your Trees.

Secondly, rou may adventure to Set the fmaller Plants, being thws raifed, and fecur'd from the reach of Cattel.

Thirdly, Your Trees faften in the Hillock againft violence of Winds, without Stakes to fret and canker them.

Fourthly, 
Fourthly, If the foil be wet it is bereby made healthy.

Fifthly, If very dry, the hillock defends from the outward heat.

Sixthly, It prevents the Couch-grafs, wbich for the firft years in fenfibly robs moft plants in Sandy grounds apt to graze. And,

Laftly, The grazing bank will recomipence the nigardly Farmer for the wafte of bis Ditch, which otherwife be will forely betbink.

In the fecond or third. year (by what time your Roots pread) the Trench, if the Ground be moift, or Seafons wet, will be neer fill'd up again by the treading of Cattel; for it ineed not be cleanfed; but then you muft renew your Thorns: ret if the Planter be curious, I frould advije a cafting of fome frall quantity of rich Mould into the bottome of the Trench the fecond year, which may improve the growth, and invite the Roots to jpread.

In this manner of Planting, where the foil is not rich, the exact Planter fhould add a little quantity to each Root of Earth from a frequented High-way, or Yard where Cattel are kept; One Load will Juffice for fix or Seven Trees; this being much more proper then rotted foil or loore Earth; the fat Miould beft agreeing with the Apple Tree.

The broader and deeper your Ditch is, the higher will be your Bank, and the fecurer your Fence; but then you mult add fome good Eartb in the fecond year, as before.

I muft fubjoyne, That only Trees of an upright growth be thus planted in open grounds; because preading of low growing Trees soill be still woithin reach of Cattel as they encreafe : Nor bave I met with any inconvenience in this kind of Tranfiplanting, (wobich is applicable to all forts of Trees) but that the Mole and the Ant may find ready entertainment the firft year, and fometime impairs a weak rooted Plant; otherwife it rarely mifcarries. In fum,

This manner of Fencing is foon executed by an indifferent Workman, who xill eafly fet and guard fix Trees in a Winter day. Thus far Mr Buckland: To which we thall only add, That thofe which are planted in the Hedg-roms need none of thefe defences; for (I am told) in Hereford-shire in the Plantations of their Quick-fets, or any other, all men did fo Juperftitioufly place a Crab-ftock at every twenty foot diftance, as if they had been under fome rigorous statute requiring it.

\section{CHAP. VIII.}

of Pruning, and Ufe of the Fruit-Trees.

7 He Branches are to be lopp $p^{*} d$ in proportion to the bruifes of the Roots, whofe fibres elfe hould only be quickned, not altogether cut off nor intangled : For the Top, let a little of each arm be lopp'd in Cider-fruit only; but for the Pears, cut two or three buds deep at the fummities of their afpiring Branches, juft above 
above the eye flanting; this will keep them from over-hafty mounting, reduce them into frape, and accelerate their bearing.

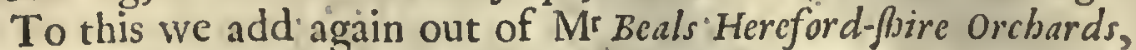
pag. 23. In a graffed plant every Boungh fhould be lopped at the ver'y tops, in Apples and Pears, not in Cherries and Plums.

In a natural Plant the Boughsifhould not at all be lopped, but fome taken off cloge to the Trunk, that the Root at firft Tranfplantation be not engag'd to maintain too many Suckers. And this wanft be clone withifuch difcretion; that the Top-branches be not too clofe together; for the natural Plant is apt to grow fpiry, and thereby fails of fruitfulnefs. "Therefore let the referved Branches be divided at a convenient roundnefs.

The Branches that are cut off may be fet, and will grow, though Somly:

If the Top prove fpiry, or the fruit unkind, then the due remedy must be in re-graffing. See chap. xxviij. in sylva.

Befides the Perrys, dri'd and preferv'd Fruit, ufeful is the PearTree (and beft the moft barren) for its excellent colour ${ }^{\circ}$ Timber, (Seldom or never worm-eaten) elpecially for Stools, Tables, Chairs, Cabinets, and very many works of the Joyner and Sculptor : And fo is likemife both the Black-cherry and the Plum-Tree. 


\section{ANIMADVER SION.}

TF fome of the following Difcourfes feem lefs cons ftant, or (upon occafion) repugnant to one another, they are to be confider'd as relating to the ferveral 1 gufts, and guizes of perfons and Countries; and not to be looked upon as recommended Secrets, much less impos'd, fartber then upon 'Tryal they may prove grateful to the Publick, and the different inclinations of thofe who affeet thefe Drinks : nor in reafon ought any to decry molbat is propos'd for the univerfal Benefit; ;ince it cofts them notbing but their civility to fo many obliging Perfons. If the Title of Aphorifms (robicb indeed was intended but for the firft Sheets of $M^{\mathrm{r}}$ Beale, though, by a mistake of the Printers, continn'd over the reft of the Difcourfes) feem to point at fomething more dogmatical, or arrogant; let the equal Reader pleafe to know, that there is notbing le $\beta$ intended by the $\mathrm{R}$. Society, then fo to pronounce concerning any their moft accurate Experiments; Thefe being but occafional Papers enter'd into their Regifter, and thrown into this form as $\mathrm{Re}^{2}$ pofitories more apt and at band; and becaufe (as I aid) they do not pretend to fine, andelaborate Methods, but to the Things as they may be of ufe, and are in their kind confiderable. 



\section{APHORISMS}

CONCERNING
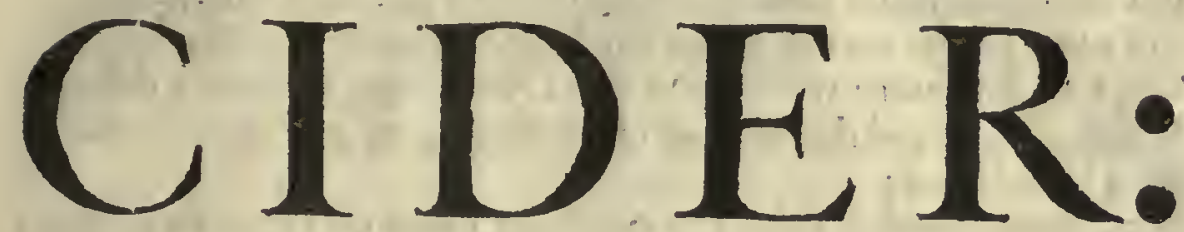

\section{By $\mathrm{M} B \mathcal{B} \& \mathcal{A} \varepsilon$.}

I.

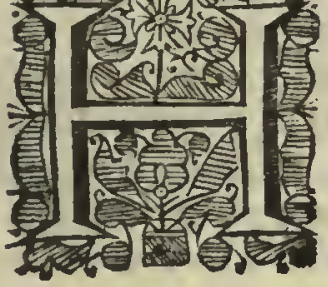
soundation fo deep as to begin with the soyl: For as no Culture or Graffs will exalt the Frunch Wines to compare with the Wines of Greece, Canaries, and Montefiafco ; fo neither will the Cider of Bromyard and Ledbury equal that of Allenfmore, Ham-lacy, and Kings-Capell, in the fame finall County of Hereford.

2. Yet the choice of the Graff or Fruit hath fo much of prevalency, that the Red-ftrake-Cider will every where excel common Cider, as the Grape of Frontignac, Canary, or Baccharach, excels the common Frençb Grape; at leaft, till by time and traduction it degenerateth.

3. I cannot divine what Soil or what Fruit would yield the beft Cider; or, how excellent Cider or Perry might be if all soils in common and all Fruit were tried; but for thirty years I have tried all forts of Cider in Hereford-ghire, and for three years I have tried the beft Cider in Somerfet-fire; and for fome years I have had the beft Cider of Kent and E/fex at my call; yet hitherto I have always'found the Cider of Hereford-ghire the beft, and fo adjudged by all good Palates.

4. I cannot undertake to particularize all kind of soil, no more than to compute how many fyllables may be drawn from the $\mathrm{Al}$ phabet; the number of Alphabetical Elements being better known then the Ingredients and Particles of Soil, 'as Chalk, Clay, Gravel, sand, Marle, (the tenacioufnefs, colour, and innumerable other qualities, thewing endlefs diverfities; )and the Fruit of Crabs, Apples, and rears, being as various as of Grapes, Figs, and Plums.

5. Yet in grofs, this I note; That as Baccbi amant colles, and a light ground, fo our beft Cider comes from the hot Rie-lands: In fat Wheat-land it is more lluggifh; and in white, ftiff Clayland (as in Woollhope in Hereford-fire) the common Cider retains a thick whey-colour, and not good: Only fuch as emergeth there 
(by the diligence of fome Art of the Inbabitants) is bright and clear, and fo lively', that they are apt to challenge the bet.

6. Some Cider mixeth kindly with Water in the Cider-mill, and will' hold out a good. fmall wine, and lefs inflaming, all the following summer. Some Cider (as of Longhope, a kind of four Woodland Country of Herefordfhire) willnot bear any mixture of Water, but foon decay, and turn more harh and four: And thus we noted in France, fome courfe Wines ftuck like paint on the Glafs, unwilling to incorporate with the Water: Vin d'Aye, and other delicate Wines, did fpread themfelves more freely, as gold is more ductile then bafer metals.

7. Some would, for a fit, extol the Cider of Pearmains, fome of Pepins; (and of Pepins I have found a congenial Liquor, lefs afflicting /plenetick perfons, as in mine own experience I conceived:) And $S^{r}$ Henry Lingen once extolled the Cider of Eleots (as richly bedewing the Glafs like beft Canaries;) and full Hogtheads of the stocking-Apple have been tried amongft us, but difappointing our expectation, though perhaps by evil ordering: Yet $\mathrm{M}^{\mathrm{r}}$ Grikten highly boafted a Mixture of Stocking-Apples and May-Pears, tried (as I take it) by himfelf: After many years trial of thofe and many other kinds, the Redftrake carried the common fame, and from moft of thofe reduced admirers. The Gennet-Moyl Cider was indeed more acceptable to unskilful and tender Palats; and it will require $\mathrm{Cuftom}$ and Fudgment to underftand the preferrency of the Red-ftrake, whofe mordicant fweetnefs moft agreeably gives the farewel, endearing the rellifh to all underftanding Palats; which both obliges, whets, and tharpens the ftomach with its mafculine and winy vigour; and many thoufands extol it for exceeding the ordinary French-Wine: But grant it fhould not be fo ftrong as Wine; let me ask how many fober perfons abroad addict themfelves to meer wine? Then compare this with diluted Wine, as ufually for temperate men。 and then let the trial be made, whether the Pepin-Cider or Red-frake will retain the moiny vigour in greater proportion of Water. Add to this, That they commonly mingle Water in the Prefs with Apples (a good quantity) whiles they grinde the Apple; and the Water thus mixed, at that time, does fo pleafingly incorporate in the grinding, fermentation, and maturity of Veflelling, that 'tis quite another and far more pleafant thing then if fo much or half fo much Water were mingled in the Cup at the drinking time; as $S$ alt on the Trencher will not give Beef, Porke, or Neats-tongue, half that fame rellifh which duly powder' $^{2} d$ and timely feafon'd.

8. I did once prefer the Gennet-moyl Cider, but had only the Ladies on my fide, as gentler for their fugary palats, and for one or two fober draughts; but I faw caufe to recant, and to confefs the Red-frake to warm and whet the stomach, either for meat or more drink.

9. The right Cider-fruit is far more fucculent, and the Liquor more eafily divides from the pulpe of the Apple, then in beft Tablefruit, in which juice and the pulp feem friendly to diffolve together on the tongues end. 10. The 
I0. The Liquor of beft Cider-fruit in the Apple, in beft feafon of ripenefs, is more brisk and finart than that which proves duller Cider: And generally the fierceft Pears, and a kind of tamer

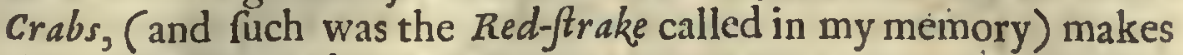
the more winy Cider.

I I. Palladius denieth Perry to bear the heat of summer; but there is a Pear in Bosbury, or thereabouts, which yields the Liquor richer the fecond year then the firft and fo by my experience very much amended the third year : They talk much higher ; but that's beyond my account.

12. As Cider is for fome time a fluggard, fo by like carc it may be retained to keep the Memorials of many Confuls; and thefe fmoaky bottles are the nappy Wine. My Lord scudamore feldome fails of three or four years; and he is nobly liberal to offer the Trial.

13. As red Apples, fo red Pears (and amongft them the red Horfpear next to the Bosbury) have held out beft for the ftomach and durance: But Pears do lefs gratifie the ftomach then Apples.

14. The feafon of grinding thefe harh Pears is after a full maturity, not till they have dropt from the Tree, and there lain under the Tree, or in heaps, a week, or thereabouts.

15. And fo of Cider-Apples, as of Grapes, they require full maturity, which is beft known by their natural fragrancy; and then alfo, as ripe Grapes require a few mellowing days; fo do all Apples, as about a week or little more, fo they be not bruifed, which foon turns to rottennefs; and better found from the Tree then rotten from the heap.

16. That due maturity, and fome reft on the heap, does make the liquor tafte rather of Apples then winy, hath no more truth, (if the Cider be kept to fit age) then that very old cheefe doth tafte of a Poffet.

17. The harher the wild-fruit is, the longer it muft lye on heaps; for of the fame fruit, fuddainly ground, I have tafted good Ver-juice; being on heaps till neer Chritmas, all good fellows called it Rhenißh-mine.

18. The Grinding is fomewhat confiderable, rather too much then too little; here I faw a Mill in Somerfet fire which grinds half a Hogghead at a grift, and fo much the better ground for the frequent rolling.

19. Soon after grinding it thould be preft, and immediately be put into the $V e f \int e l$, that it may ferment before the $\beta_{\text {pirits }}$ be diffipated; and then alfo in fermenting time the Vent-biole fhould not be fo wide as to allow a prodigal wafte of the $/$ pirits; and as foon as the ferment begins to allay, the Veffels thould be filled of the fame, and well ftopped.

20. Of late 'tis much commended, that before it be preft the Liquor and Muft thould for four and twenty hours ferment together in a Vat for that purpofe, covered, as Ale or Beer in the reft-vat, and then tunned up. This is faid to enrich the liquor, and to give.it fomewhat of the tindture of fome red Apples, as I have feen, and very well approved.

$\mathrm{D}_{2}$ 2I. Ag 
21. As Sulphur hath fome ufe in Wines, fo fome do lay Brintftone on a ragge, and by a wire let it down into the Cider-veffel and there fire it; and when the Veflel is full of the fmoak the liquor fpeedily poured in ferments the better. I cannot condemn this, for sulpbur is more kind to the Lungs than Cider, and the impurity will be difcharged in the ferment.

22. Apples over-long hoarded before grinding will for a long time hold the liquor thick; and this liquor will be both pleafant, and as I think, wholefome; and we fee fome rich Wines of the later Vintage, and from Greece, retain a like craflitude, and they are both meat and drink.

23. I have feen thick harfh Cider the fecond summer become clear and very richly pleafant; but I never faw clear acid cider recover.

24. Wheat or Leven is good and kind in Cider, as in Beer; $\mathrm{J}_{22}$ niper-berries agree well and friendly for Coughs, weak Lungs, and the aged, but not at firft for every Palate: The moft infallible and undifcerned improver, is Muftard a Pint to each Hogjhead, bruifed, as for fauce, with a mixture of the fame Cider, and applied as foon as the Veffel is to beclofed after fermenting.

25. Bottleing is the next improver, and proper for Cider; fome put two or three Raifins into every Bottle, which is to feek aid from the Vine. Here in somerfet/hire I have feen as much as a Wal-nut of Sugar, not without caufe, ufed for this Country Cider.

26. Crabs do not haften the decay of Perry, but preferve it, as salt preferves flefh. But Pears and crabs being of a thoufand kinds require more Aphorifmes.

27. Neither Wheat, Leven, sulphur, nor Muftard, are ufed but by very $\mathrm{few}_{\varepsilon} ;$ and therefore are not neceflary to make Cider laft well, for two, three or four years.

28. The time of drawing Cider into Bottles is beft in March, it being then clarified by the Winter, and free from the heat of the sun.

29. In drawing, the beft is neereft the beart or middle of the Vef$\mathrm{rel}$, as the relkin the Egge.

30. Red-fraks are of diverskinds, but the name is in Herefordfoire appropriated to one kind, which is fair and large, of a high purple colour, the fmell Aromatical, the Tree a very Jorub, fome bearing a full burthen, and feldom or never failing till it decays, which is much fooner then other Apple-trees. 'T is lately fpread all over Herefordßsire; and he that computes fpeedy return, and true Wine, will think of no other Cider-apple, till a better be found.

3I. I faid the Red-ftrake is a fmall forub, 'tis of fmall growth where the Cider proves richeft, for ought we have yet feen in Herefordfoire, viz. in light quick land; and if the land be very dry, jejune and thallow, that and other Cider-fruit (efpecially the Gennet-mogle) will fufpend the ftore of fruit alternatively every other year; except fome Blafts or furprifing Frofts in the Spring alter that Method; for two bad years feldom come together, very hardly three. 
32. In good foil, I mean of common field (for fat land is not beft for Cider fruit, but common arable) I have feen the Trees of good growth, almoft equalling other Cider-trees, the Apple larger and feldom failing of a good burthen: thus in the Vales of Wheatlands, in ftrong Glebe or Clay, where the Cider is not fo much extolled: but ftill sack is Sack, and Canary differs from Claret; fo does the Red-ftrake-Cider of the Vale excell any other Cider of the forcible foil.

33. Yet this diftinction of soil requires much experience, and great heed, if we infift upon accurate directions; for as Laurenburg faith, in pingui folo non feruntur, omnia recte, neque in macro nibil. And for Gardens, Flowers and orchards, I would chufe many times fuch lands as do not pleafe the Husbandman, either for Wheat or fweet Pafture, which are his chief aims; and thus Laurenburg, In Arida os tenui terra felicius proveniunt Ruta, Allium, Petrofelinum, Crocus, Hyfopus, Capparis, Lupini, Satureia, Thymus; Arbores quoque tenue \&o macilentum folum amant; itemque frutices plerique Humidi arbores, fcil.Pomi, Pyri, Cerafus, Prunus, Perfica, Cotonea, Mori, Juglans, Coryli, Staphylodendrum, Mepilus, Ornus, Caftanea, doc. Frutices, fcil.Vitis, Berberis, Genifta, funiperus, Oxyacantba, Periclymenum, Rofa, Ribefium, vva, spina, Vaccinia, \&rc.

34. But here alfo we muft diftinguifh, that $P e$ ars will bear in a very ftony, bungry, gravelly-land, fuch as Apples will not bear in; and I have feen Pears bear in a tough binding hungry Clay, when Apples could not fo well bear it (as the fmooth rinds of the Peartrees, and the Molfie and cankered rinds of the Apple-trees did prove) the root of a Pear-tree being it feems more able to pierce a ftony and ftiff ground.And Cherries, Mulberries and Plums, can rejoyce in a richer foil, though by the fmallnefs of the Roots, the fhallow. er foil will fuffice them. And require a deeper ground, and will bear with fome degrees of hungry land, if they be fupplied with a due meafure of fucculency, and neighbouring moifture; and the other farubs, according to the fimalnefs of their roots, do generally bear a thinner land. I have feen a foil fo much too rank for Apples and Plums, that all their fruit from year to year were always worm-eaten, till their lives were forfeited to the fire.

35. To take up from thefe Curiofities, the moft ufeful refult to our purpore; we have always found thefe orchards to grow beft, laft longeft, and bear moft, which are frequently tilled for Barley, Wheat or other Corn, and kept (by Culture and feafonable reft) in due ftrength to bear a full crop. And therefore, whereas the Redftrake might otherwife without much injury be planted at fifteen or twenty foot diftance, and the beft diftance for other Cider-fruit hath heretofore been reputed thirty or two and thirty foot; very good husbands do now allow in their largeft Inclofures (as of 2040 or 100 Acres) fifty or fixty foot diftance, that the Trees may not much hinder the Plow, and yet receive the benefit of compoft ; and a Horfe-teem well governed will (without any damage of danger) plow clofe to the Trees. 
36. In fuch foil as is here required, namely of good Tillage, an orchard of graffed Red-frakes will be of good growth, and good burthen, within ten or twelve years, and branch out with good ftore to begin an encouragement at three years graffing; and (except the land be very unkind) will not yield to any decay within fixty or eighty years, which is a mans age.

37. In fome Jheets I rendered many Reafons againft Mr.Auftirs of Oxford, why we hould prefer a peculiar Cider-fruit, which in Herefordfoire are generally called Mufts; (both the Apple and the Liquor, and the Pulpe together in the contufion) as from the Latine Muftum. White-mufts of divers kindes, Red-check'd and Redfrrak"d Mufts of feveral kinds, Green-mujts called alfo Green-fillet, and Blew-potted: Why, I fay, we thould prefer them for Cider, before Table-fruit, as Pepins, Pearmains, drc. and I do ftill infift on them: I. The Liquor of thefe cider-fruits and of many kinds of auftere fruit, which are no better than a fort of full fucculent Crabs, is more fprightful brifk and woiny. For Effay, I fent up many bottles to London, that did me no difcredit. Secondly, One buthel of the Cider-fruit yields twice or thrice as much liquor. Thirdly, The Tree grows more in three or four years then the other in ten years, as I oft times remarked. . Fourthly, The Tree bears far greater ftore, and doth more generally efcape Blafts and Frofts of the spring : I might add, that fome of thefe, and efpecially fuch Pears as yield the beft Perry, will beft efcape the hand of the Thief, and may be trufted in the open field.

38. By the firft, second and fourth of thefe Reafons, I muft exclude the Gennet-Moyle from a right Cider-fruit, it being dry and very apt to takefrofty blafts; yet it is no Table-fruit"but properly a baking fruit, as the ruddy colour from the oven thews.

39. I faid that the right Cider-fruit, generally called $M u r f s$, and deferving the Latine name Mustum, is of divers kinds; and I have need to note more exprefly that there is a Red-ftrak'd Must (as I have often feen) but not generally known, that is quite differing from the famous Red-ftrake, being much lefs, fomewhat oblong and like fome of the white Musts in Thape, and full of a very good winy liquor. I could willingly name the perfons and place where the diftinct kinds are beft known: it was firft thewed me by Jobn Nafh of Afpperton in Herefordfhire; and for fome years they did in fome places dittinguin a Red-Jtrake, as yielding a richer Redftrak'd-cider of a more fulvous or ruddy colour; but this difference, as far as I could find, is but a choice of a better infolated or ruddy fruit of the beft kind, as taken from the Soutb-part of the Tree or from a foil that renders them richer. But my Lord scudamore. is fafely of the beft fort; and M. Whingate of the Grange in Dimoc, and fome of King's-capel, do beft know thefe and other differences, straked, Muft, right Red-ftrake, Red-red-ftrake, \&rc.

40. The greenilh $M u f t$, (formerly called in the Languiage of the Corntry, the Green-fillet) when the Liquor is of a kindly ripenefs, retains a greene $\beta$ equal to the Rhenijh-gla $\beta$; which I note for them that conceive no cider to be fit for ufe till it be of the colour of old sack.

4I. To 
41. To direct a little more caution, for inquiry of the right Red-ftrake, I hould give notice that fome Moneths ago, M. Philips of Mountague in. Somerfetflire; thewed me a very fair large Redfrake Apple, that by fmell and fight feemed to me and to another of Herefordfhire, then with me to be the beftRed-frake; but when we did cut it and talte it, we both denied it to be right (the other with much more confidence then my felf) but M. Pbilips making cider of it, this week invited me to it, afuring that already it excels all High-country-mines. It had not fuch plenty of juice as our Red-ftrakes with us, and it had more of the pleafantnefs of Tablefruit, which might be occafioned, for ought I know, by the richer foil.

42. I may now ask why we thould talk of other cider-fruit or Perry, if the beft Red-ftrake have all the aforefaid pre-eminences of richer and more winy liquor, by half fooner an orchard, more conftantly bearing, oc. An Orchard of Red-ftrakes is commonly as full of fruit at ten years, as other Cider-fruit at twenty years, or as the Pepin and Pearmain at thirty or thereabout.

43. But all foils bear not Apples; therefore for Perry; which is the goodlier Tree for a Grove, to Thelter a houfe and walks from summers beat and Winters cold winds, and far more lafting; the pleafanteft Cider-pear of a known name amongft them, is the Hor.e-pear. And it is much argued, whether the White-borfe-pear, or the ked-borfe-pear be the better; where both are beft, within two Miles they differ in judgement. The Pear bears almoft its weight of fprightful woiny liquor; and I always preferred the taxny or ruddy Hor e-pear, and generally that colour in all Pears that are proper for Periy.

44. I rejected Palladius againft the durablenefs of Perry; his words are, Hyeme durat, fed prima acefcit aftate, Tit.25.Febr. pofhbly fo of common Pears, and in hotter Countries; but from good Cellars I have tafted a very brifk lively and miny liquor of thefe Horfe-pears during the end of summer; And a Bosbury-pear I have mamed and often tried, which without bottleing, in common Hog $\mathrm{f}^{-}$ heads of vulgar and indifferent Cellars, proves as.well pleafanter as richer the fecond year, and yet allo better the third year. A very honeft worthy and witty Gentleman of that neighbourhood would engage to me that in good cellars, and in careful cuftody, it paffeth any account of decay, and may be beightened to a kind of Aqua-vite. I take the information worthy the ftile of our modern improvements.

1 he Pear-tree grows in common fields and wild ftony ground, to the largeness of bearing one, two, three or four Hog foeads each year.

45. This Bosbury-tree, and fuch generally that bear the moft lafting Liquor and winy, is of fuch unfufferable tafte, thit hungry swine will not $\int$ mell to it; or if bunger tempt them to tafte, at firft crufh they Thake it out of their mouths; (I fay not this of the Horfe-pear ) and the Clowns call other Rears, of beft Liquor, Choakpears, and will offer money to fuch as dare adventure to tafte 
them, for their Jport; and their mouths will be more ftupified then at the root of Wake-robin.

46. A row of crab-trees will give an improvement to any kind of Perry; and fince Pears and Crabs may be of as many kinds as there are kernels, or different kinds or mixtures of foils; in a general $c$ baracter I would prefer the largeft and fulleft of all auftere juices.

47. M. Lill of Marole (aged about go years) ever obferved this Rule, to graff no mild Pear-tree till he faw the fruit; if it proved large, juicy and brisk, it failed not of good Liquor. But I fee caufe to fay, that to graff a young tree with a riper graff, and known excellency, is a fure gain and haftens the return.

48. M. Speke (laft bigh sheriff of somerfetfhire) thewed me in his Park fome ftore of Crab-trees, of fuch huge Bulk, that in this fertile year he offered a mager, that they would yield one or two Hogfeads of Liquor. each of them; yet were they fmall dry Crabs.

49. I have feen feveral forts of crabs (which are the natural Apple, or at worft but the Wild-apple) which are as large as many forts of Apples, and the Liquor miny.

50. I have difclaimed the Gust of Funiper-berries in Cider; I tried it only once for my felf, and drank it before Christ mas: poffibly inmore time the rellith had been fubdued or improved, as of Hops in ftale Beer, and of Rennet in good Parmafan. Neither was the $G u j t$ to me otherwife unpleafant then as Annife-feeds in Bread, ratherftrange then odious.; and by cuftom made grateful, and it did haften the clarification, and increafe the brifknefs to an endlefs Jparkling : thus it indulgeth the Lungs, and nothing more cbeap; where Juniper grows a Girl may fpeedily fill her lap with the Berries.

If Burbados Ginger be good, cheaper, and a more pleafant preferver of Beer, it muft probably be moft kind for Cider: For firt, of all the improvers that I could name, bruifed Must ard was the beft; and this Ginger hath the fame quick, mordicant vigor, in a more noble and more Aromatique fragrancy. Secondly, Cider (as I oft complain) is of a Dugginh and fomewhat windy nature; and for fome Moneths the beft of it is chain'd up with a cold ligature, as we phancie the fire to be lock'd up in a cold Flint. This will relieve the prifoner. And thirdly, will affift the soiny vigor for them that would ufe it in ftead of a fparkling Wine. . Fourthly, 'Tis a good fign of much kindnels, and great friendihip : it will both enliven the ferment for fpeedier maturity, and alfo hold it out for more duration, bath which offices it performs in Beer.

51. Cider being windy before maturity, fome that muft not wait the leifure of beft seafon do put fprigs of Rofe-mary and Bays in the Vefel; the firft good for the bead, and rot unpleafant; the fecond, an Antidote againn InfeCtions; but lefs pleafant till time hath incorporated the Taftes. .

52. And why may we not make mention of all thefe Mixtures, as well as the Ancients of their Vinum Marrubii, Vinum Abrotonites, 
AbJyntbites, Hyffopites, Maratbites, Thymites, Cydonites, Myrtites, scillites, Violaceum, sorbi, duc.

53. And, for mixtures, I think we may challenge the Ancients, in naming the Red-rajpy; of which there is in this County a Lady that makes a Bonella, the beft of Summer drinks: And more yet if we name the Clove-july-flower, or other Fuly-flowers, a moft gratefull Cordial, as it is infufed by a Lady in Staffordhire, of the Family of the Deverenx's, and by fome Ladies of this Country.

54. I could alfo give fome account of Cherry-zxine, and Wine of Plums; their vaft ftore in fome places, under a peny the pound, and their expedite growth makes it cheap enough, and as in the other, fo in thefe, the large Engligh or Dutch harp Cherry, and the full black, tawny Plum, as-big as a Walnut (not the kind of Heartcherries, nor the Plum which divides from the ftone) make the Wine. Their cheapnefs thould recommend them to more general ufe at Tables, when dryed (an eafie art) and then wholefomer.

55. To return for Red-ftrake; 'tis a good drink as foon as well fermented, or within a moneth, better after fome Frofts, and when clarified; rich Wine, when it takes the colour of old Sack. In a good Cellar it improves in Hogheads the fecond year; in Bottles and fandy Cellars keeps the Records of late revolutions and old $M a-$ joralties. 2uere the manner of laying them up in fand-boufes.

56. I tried fone Bottles all a summer in the bottom of a Fountain; and I prefer that way where it may be had. And 'tis fornewhat ftrange if the Land be neither $d r y$ for a fand-boufe, nor fountainous for this better expedient. When Cider is fetl'd, and altogether, or almoft clarifi'd, then to make it $\beta$ priteful and winy, it fhould be drawn into well cork'd and well bound bottles, and kept fome time in fand or water; the longer the better, if the kind be good. And Cider being preferv'd to due age, bottl'd and kept in cool places, confervatories, and refrigerating lprings) it does almoft by time turin to Aqua-vite; the Bottles fmoak at the opening, and it catchesflame fpeedily, and will burn like pirit of Wine, with a fiery tafte; and it is a laudable way of trying the vigour of Cider by its promptnefs to $b_{u r} n$, and take fire, and from the quantity of Aqua-vila which it yields.

57. I mult not prefcribe to other Palates, by afferting how good Cider may be made, or to compare it with Wines: But when the late king (of blefled inemory) came to Hereford in his diftrefy, and fuch of the Geutry of Worcefterfhire as were brought thither as Prifoners.; both King, Nobility and Gentry, did prefer it before the beft Wines thofe parts afforded; and to my knowledge that Cider had no kind of Mixture. Generally all the Gentry of HerefordBire do abhor all mixtures.

Yet if any man have a defire to try conclufions; and by an harmlefs Art to conve1t Cider into richi Canary-wine; let the Cider be of the former year, $M$ sefculine and in full body, yet pleafant, and well tafted of the Apple: into fuch Cider put a fpeonful, or $\int 0$, of the Jpirit of Clary, it will make the Liquor fo perfectly to refemble the very beft Canary, that few. good and exercis'd ralates will be able to diftinguifh it.

E.

SIR 


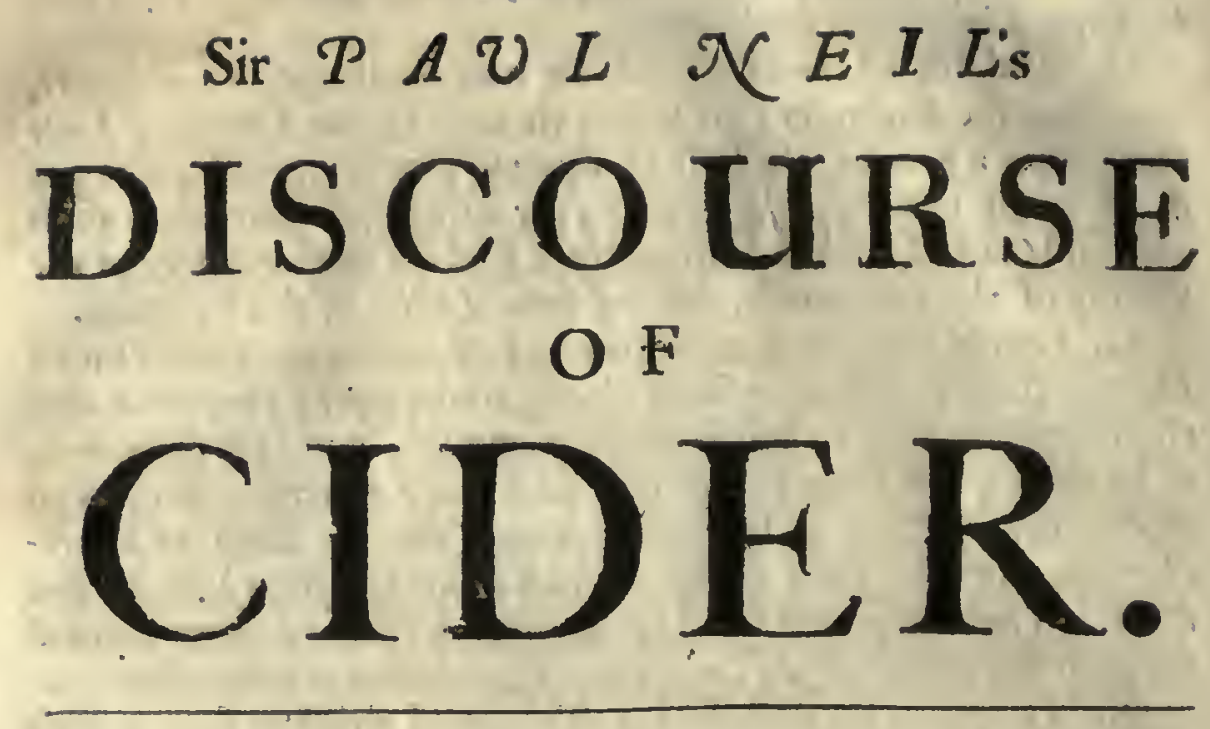

My Lord,

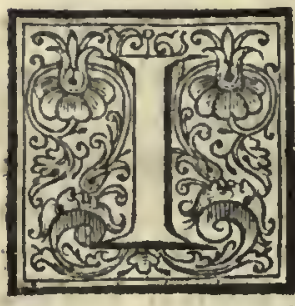

$\mathrm{N}$ obedience to the Commands of this Honourable Society, I have at length endeavoured to give this brief Account of that little which I know concerning the ordering of Cider; and in tbat I thall propound to my felf $f(x)$ things.

Firft, To thew that cider made of the beft is to fay) the pleafantelt cider.

Eating-apples muft needs be once the beft; (that

secondly, That hitherto the general opinion hath been otherwife, and that the reafon of that miftake was the not apprehending the true caufe why the Pepin-cider, $c^{2} c$. did not retain its fweetnefs, when the Hard-apple-cider did.

Thirdly, What is the true caufe that Pepin-cider, ufed in the ordinary method, will not retain its fweetnefs.

Fourthly, How to cure that evil in Pepin-cider.

Fiftly, A probable conjecture, how in fome degree by the fame Method to amend the Hard-apple-cider, and French-wine.

sixtbly, That what is here propounded cannot chufe but be wholfome, and may be done to what degree every mans Palate thall wifh.

Having now told your Lordflip, what I will endeavour to do before I enter upon it, I muft declare what I will not in the leaft pretend to do.

I. I do not pretend to any thing concerning the planting and graffing of Trees, duc.

Nor what Trees will fooneft bear or laft longeft.

Nor what forts of Trees are the beft bearers, and may with leaft danger grow in Common fields.

Nor what fort of fruit will yield the greateft ftore of Cider.

Nor what Cider will keep the longeft, and be the ftrongeft, and wholefomeft to drink conftantly with wzeat. 
The only thing I thall endeavour, being to prefcribe a way to make a fort of Cider pleafant and quick of tafte, and yet wholefome to drink, fometimes, and in a moderate proportion : For, if this be an Herefie, I muft confels my felf guilty; that I prefer Canary-wine, Verdea, the pleafantert Wines of Greece, and the Highconntry-mines before the barfh Sherries, Vin de Hermitage, and the Italian and Portugal rough Wines, or the beft Graves-wines; not at all regarding that I ain told, and do believe, that thefe barfh Wines are more comfortable to the ftomack; and a surfeit of them lefs noxious, when taken; nor to be taken but with drinking greater quantities then can with fafety be taken of thofe other pleafant Wines : I fatisfying my felf with this; that I like the pleafant Wines beft; which yet are fo wholefome that a man may drink a moderate quantity of them without prejudice.

Nor fhall I at all concern my felf, whether this fort of cider I pretend to is fo vinous a liquor; and confequently will yield fo much ßirit upon Diftillation, or fo foon make the Country-man think himfelf a Lord, as the Hard-apple-cider will do: nor whether it will laft fo long; for it is no part of my defign to perfwade the World to lay by the making of Hard-apple-cider; but rather in a degree to thew how to improve that in point of pleafantnefs, and that by the making and rightly ordering of Cider of the beft Eating-apples; as Golden-pepins, Kentifh-pepins, Pear-mains, bu. there may be inade a more pleafant liquor for the time it will laft, then can be produced from thofe Apples which I call Hard-apples, that is to-fay, Red-ftrakes, Gennet-moyles, the Broomsbury-crab, \& c. . which are fo barfh that a Hog will hardly eat them.

Nor thall I at all meddle with the making of Perry, or of any mixed drink of the juyce of Apples and Pears; though poffibly what I thall fay for Cider may be aptly applied to Perry alfo.

For the firft particular, I afjerted that the beft Apples would make the pleafanteft, which in my fence is the beft Cider; (and I account thofe the beft Apples, whofe juyce is the pleafanteft at the time when firft preffed, before fermentation) I thall need (befides the experience of the laft ten years) only to fay, that it is an undeniable thing in all Wines, that the pleafanteft Grapes make the richeft and pleafanteft Wines; and that Cider is really but the Wine of Apples, and not only made by the fame way of Comprees 2 on; but left to it felf hath the fame way of Fermentation; and therefore muft be liable to the fame meafures in the choice of the materials.

To my fecond Affertion, that this truth was not formerly owned by reafon that in Herefordpire, and thofe Countries where they abound both with Pepins and bard-apples of all forts, they made Cider of both forts, and ufed them alike; that is; that as foon as they ground and prefjed the Apples and ftrained the Liquor, they put it into their $V e f f j l s$ and there let it lye till it had wrought, and afterwards was fetled again and fined; as not thinking it wholefome to drink till it had thus. (as they call it) purg'd it felf; $\mathrm{E} 2$ and 
and this was the frequent ufe of molt men in the more soutberse and WeSEern parts of England alfo. Now when Cider is thus ufed; it is no wonder that when they came to broach it, they for the moft part found their Pepin-cider not fo pleafant as their Moyle or Red-frake-cider; but to them it feenied a wonder, becaufe they did not know the reafon of it (which hall be my next work to make out) for till they knew the reafon of this effect, they had no caufe but to think it was the nature of the feveral Apples that produced it ; and confequently to prefer the Hard-apple-cider, and to ufe the other Apples (which were good to eat raw) for the Table. : which was an ufe not lefs neceflary, and for which the hard-apples were totally improper.

To my third Affertion; which is, that in Herefordflire they knew not what was the true caufe why their Pepin-Cider (for by that name I thall generally call all forts of cider that is made of Apples good to eat raw) was not, as they ufed it, fo good as the Cider made of bard-apples (for by that name, for brevities fake, I thall call the Cider of Mogle; Red-ftrake, and all other forts of barfh Apples, not fit to eat raw.) Firft, I fay, for all liquors that are Vinous, the caufe that makes them fometimes harder or lefs pleafant to the tafte, then they were at the firt preffing, is the too much fermenting : If Wine or Cider by any accidental caufe do ferment twice it will be harder then if it had fermented but once; and if it ferment thrice, it is harder and worfe then if it had fermented but twice : and fo onward, the oftner it ferments and the longer it ferments, it ftill grows the harder. This being laid as a foundation, before we proceed further we muft firft confider what is the caufe of fermentation in Wine, Cider, and all other. Vinous Liquors. Which (in my poor opinion) is the grofs part of the Liquor, which feapes in the ftraining of the Cider (for in making of Wine, I do not find that they ufe the curiofity of ftraining ) and which is generally known by the name of the Lee of that (Wine or) Cider. And this Lee I thall, according to its thicknefs of parts, diftinguifh into the gro $/$ Lee, and the flying $L e e$.

- Now, according to the old method of making and putting up of Cider, they took little care of putting up only the clear part of the Cider into their Veffels or Cask; but put them up thick and thin together, not at all regarding this Separation; for experimentally they found that how thick foever they put it up, yet after it had throughly wrought or fermented and was fetled again, it would ftill be clear; and perchance that which was put up the fooneft after it was prefled and the thickeft, would, when the fermentation was over, be the cleareft, the brifkeft, and keep the longert. This made them confidently believe that it was not only not inconvenient to put it up quickly after the preffing, but in fome degree neceffary alfo to put it up foon after the pref $\int i n g$, fo that it might have fo inuch of the Lee mixed with it, that it might certainly, foon, and ftrongly put it into a fermentation, as the only means to make it wholfome, clean and brisk; and when it ci.... ther 


\section{Aphorifms concerning Cider.}

ther did not (or that they had reafon to doubt) that it would not work or ferment ftrongly enough, they have ufed to put in Mis ftard or lome other thing of like nature to increafe the fermen: tation.

Now that which in Cider of Pepins hath been a caufe of gteater fermentation then in Cider of bard-apples, being both ufed after the former method, is this, that the Pepins being a fofter fruit are in the Mill bruifed into fmaller particles then the harder forts of Apples; and confequently more of thofe fimall parts pafs the ftrainer in the Pepin-cider then in the Cider of bard-apples, which caufeth a ftronger fermentation, and (according to my former principle) a greater lofs of the native fweetnefs then in that of Hard-apple-cider; and not only fo, but the Lee of the Hard-applecider being compounded of greater particles then the Lee of the Pepin-cider, every individual particle is in it felf of a greater weight then the particles of the Lee of the Pepin-cider; and confequently lefs apt to rife upon finall motions, which produceth this effect; that when the fermentation of the Hard-apple-cider is once over, unlefs the Veffel be ftirred, it feldom falls to a fecond fermentatit. on; but in Pepin-cider it is otherwife : For if the grof Lee be ftill remaining with the Cider, it needs not the motion of the Veffel to caufe a new fermentation, but every motion of the Air by a change of weather from dry to moift will caufe a new fermentation, and confequently make it work till it hath deftroyed it felf by lofing it's native fweetnefs. And this alone hath been the caufe, why commonly when they broach their Pepin-cider they find it fo unpleafant, that generally the Hard-apple-cider is preferred before it, although at firft it was not fo pleafant as the Pepin-cider. Yet after this mifchief hath prevailed over the Pepin-cider, it is no wonder to find the Hard-apple-cider remaining not onely the ftronger, but even the more pleafant tafted. This to me feems fatisfactory for the difcovery of the cause, why in Herefordfsire the Hard-apple-cider is preferred before the Pepin-cider. But perhaps it may by fome be objected, that they have before the ters years, in which you pretend you found this to be the caufe of fpoiling the Pepin-cider, been in Herefordfhire, and tafted the beft Cider that Country did afford; and yet it was not like the Pepin-cider they had before then tafted in other parts. :To this I do anfwer, at prefent, briefly, that by fome iniftake, or chance, the maker of this Pepin-cider, which proved good, had done that, or fomewhat like that, which under the next Affertion I thall fet down, as a Method to cure the inconveniences which happen to Pepin-cider, by the fuffering it to ferment too often, or too ftrongly; but till that be explained it would be improper to thew more fully what thefe particular accidents might poffibly be, which (without the intention of thofe perfons which made the cider) caufed it to prove much better then their expectation, or indeed better then any could afterwards make : they poffibly affigning the goodnefs of that Cider to fomewht that was not really the cause of that. effect. 
To juftifie my fourth Affertion, and thew a Method how to cure the incoveniency which happens to Pepin-cider by the over working, I muft firft take notice of fome things which I have been often told concerning Wine, and which indeed gave me the light to know what was the canfe which had made Pepin-cider that had wrought long, bard when it came to be clear again. The thing I mean, is, that in diversparts, and even in France they make tbree forts of Wine out of one and the fame Grapes; that is, they firft take the juice of the Grapes without any more preffing then what comes from their own weight in the Vat, and the bruifing they have in putting into Veffel, which caufeth the ripeft of thofe Grapes to break, and the juice without any preffing at all makes the pleafanteft and moft delicate Wine: And if the Grapes were red, then is this firft Wine very pale. The fecond fort they prefs a little, which makes a redder Wine, but neither fo pleafant as the firft, nor fo harfh as the laft, which is made by the utmoft preffing of the very skins of the Grapes, and is by much more harn, and of deeper colour. then either of the other two. Now I prefurne the caufe of this (ar leaft in part) to be, that in the firft fort of Wine, which hath little of the fubftance, befide the very juice of the Grape, there is little Lee, and confequently little fermentation; and becaufe it doth not work long, it lofeth but little of the original fweetnefs it had : The fecond fort being a little more preffed hath fomewhat more of the fubftance of the Grape added to the jwice; and therefore having more of that part which caufeth fermentation put with.it, ferments more frongly, and is therefore, when it hath done working lefs pleafant then the firft fort, which wrought lefs. And for the lame reafon the third fort being molt of all preffed, hath moft of the fubftance of the Grape mingled with the Liquor, and worketh the longeft: but at the end of the working when it fettles and is clear, it is much more harfh then either of the two firft forts. The thought of this made me firft apprehend that the fubftance of the Apple mingled with the juice, was the caufe of fermentation, which is really nothing elfe but an endeavour of the Liquor to free it felf from thofe Heterogeneous parts which are mingled with it: And where there is the greateft proportion of thofe diffimilar parts mingled with the Liquor, the endeavour of Nature muft be the ftronger, and take up more time to perfect the feparation: which when finifhed leaves all the Liquor clear, and the grofs parts fetled to the bottom of the $\mathrm{Veffel}$; which we call the Lee. Nor did this apprehenfion deceive me; for when I began (according to the Method which I thall hereafter fet down) to feparate a confiderable part of the Lee from the Cider before it had fermented, I found it to retain a very great part of its original fweetnefs, more then it would have done if the Lee had not been taken away before the fermentation; and this not once, but conftantly for feven years.

Now the Metbod which I ufed, was this: When the Cider was firft ftrained, I pur it into a great' $V a t$, and there let it ftand $t w e n-$ ty four hours at leaft (fometimes more, if the Apples were more ripe 
then ordinary) and then at a tap before prepared in the Veffel three or four inches from the bottom I drew it into pails, and from thence filled the Hogfhead (or leffer $V e(J e l)$ and left the greateft part of the Lee behind; and during this time that the Cider ftood in the Vat, I kept it as clofe covered with hair-clothes or facks as I could; that fo too much of the $\beta$ pirits might not Evaporate.

Now poffibly I might be afked why I did not, fince I kept it fo clofe in the Vat, put it at firft into the Veffel ? To which I anfwer, that had I put it at firft into the Veffel, it would poffibly (efpecially if the weather had chanced to prove wet and warm) have begun to ferment before that time had been expired; and then there would have been no poffibility to have feparated any part of the großs Lee, before the fermentation had been wholly finifhed; which keeping it only covered with thefe clothes was not in danger : For, though I kept it warm in fome degree, yet fome of the $\int p i$ rits had fill liberty to evaporate; which had it been in the Hogfbead with the Bung only open, they would not fo freely have done; but in the firft 24 bours it would have begun to ferment, and fo my defign had been fully loft : For thofe $\beta$ irits if they had been too ftrongly reverberated into the Liquor, would have caufed a fermentation before I could have taken away any part of the groß Lee. For the great myftery of the whole thing lyes in this, to let fo many of the firits evaporate, that the liquor fhall not ferment before the groß Lee be taken away; and yet to keep/pirits enough tocaufe a fermentation when you would have it. For if you put it up as foon as it is ftrained, and do not let fome of the Pirits evaporate, and the groß Lee by its weight only to be fepara * ted without fermentation, it will ferment too much and lofe its fweetnefs; and if none be left, it will not ferment at all; and then the Cider will be dead, flat and fowre.

Then after it is put into the $V e f f e l$, and the Veffel fill'd all but a little (that is, about a Gallon or thereabout) I let it ftand (the Bung * bole being left only covered with a paper, to keep out any duft or filth that might fall in) for 24 bours more; in which time the grofSeft part of the Lee being formerly left in the Vat, it will not ferment, but you may draw it off by a Tap fome two or three inches from the bottom of the Veffel, and in that' fecond Veffel you may ftop it up, and let it Atand fafely till it be fit to Bottle; and poffis bly that will be within a day or more: 'but of this time there is no certain meafure to be given; there being fo many things that will make it longer, or lefs while before it be fit to bottle. As for $E_{x}$ ample, If the Appleswere over-ripe when you ftamped them, or ground them in the Mill, it will be the longer before it will be clear enough to Bottle; or if the weatber prove to be warmer or moifter then ordinary : or that your Apples were of fuch kinds, as with the fame force in the ftamping or grinding they are broken ir:to fmaller particles then other Apples that were of harder kinds.

Now, for knowing when it is fit to. Bottle, I know no certain Rule that can be given, but to broachithe Vefjel with a fmall piercer, and in that bole fit a peg, and now and then (two or times in a 
day) draw a little, and fee what finenefs it is of; for when it is bottled it muft not be perfectly fine; for if it be fo, it will not fret in the bottle, which gives it a fine quicknefs, and will make it mantle and fparkle in the glafs when you pour it out: And if it be too thick when it is bottled, then, when it hath ftood fome time in the bottles it will ferment fo much that it may poffibly either drive out the corks, or break the bottles, or at leaft be of that fort (which fome call Potgun-drink) that when you open the bottles it will fly about the houfe, and be fo windy and cutting that it will be inconvenient to drink : For the right temper of Bottle-Cider is, that it mantle a little and $\beta$ arkle when it is put out into the gla $\beta$; but if it froth and fly it was bottled too foon : Now the temper of the $C_{i-}$ der is fo nice, that it is very hard when you bottle it to foretell which of thefe two conditions it will have: but it is very eafie within a few days after (that is to fay, about a week, or fo) to find its temper as to this point. For firt, if it be bottled too foon; by this time it will begin to ferment in the Bottles, and in that cale you muft open the Eottles, and let them ftand open two or three minutes, that that abundance of pirits may have Vent, which otherwife kept in would in a fhort time make it of that fort I called before Pot-gur-drink; but being let out, that danger will be avoided, and the cider (without danger of breaking the bottles). will keep and ferment, but not too much. Now this is fo calie a remedy, that I would advife all men rather to erre on thehand of bottling it toofoon, then lot it by too fine when they bottle it; for if $\mathrm{fo}_{\mathrm{O}}$ it will not fret in the bottle at atl; and, confequently, want . that bxisknes 3 which is defireable.

Yet even in this cafe there is a Remedy, but fuch a one as I am always very careful to avoid, that fo I may have nothing (how little foever) in the Cider but the juice of the Apple: But the reme$d y$ is, in cafe you be put to a neceffity to ufe it, that you open every bottle after it hath been bottled about a week or fo, and put into each bottle a little piece of $w$ bite sugar, about the bignefs of a Nutmeg, and this will fet it into a little fermentation, and give it that briskness which otherwife it would have wanted. But the other way being full as eafie, and then nothing to be added but the juice of the Apple to be frimply the fubftance of your Cider, I chufe to prefer the errour of being in danger to bottle the Cider toofoon, rather than too late: Nay fometimes in the bottling of one and the fame Hog head (or other Veffel) of Cider, there may the firft part of it be toofine; the fecond part well; and the laft not fine enougli: : and this happens when it is broacbed firft above the middle, and then below; and then when it begins to run low, tilted or raifed at the further end, and fo all drawn out. But to avoid this inconvenience, I commonly fet the bottles in the order they were filled, and fo we need not open all to fee the condition of the Cider; lut trying one at each cnd, and one in the middle; will ferve the turn: And to prevent the inconveniency, broach not at all above the middle, nor too lom; and when you have drawn all that will run at the Tap, you may be 


\section{Apborifms concerning Cider.}

fecure it is fo far of the fame temper with the firft boitle. And then tilt the Veffel; but draw no more in three or four hours at the leaft after, and fet them by themfelves, that fo, if you pleafe, you may three or four days after pour them off into other bottles, and leave the gro/s behind: And by this means though you have a lefs number of bottles of cider then you had, yet this will continue good, and neither be apt to fly, nor bave a fediment in the bottle, which after the firft glaß is filled will render all the reft of the bottle thick and miuddy.

By all this which I have faid, I think it may be made out that thofe perfons which I mentioned in the end of the laft Parragriph, that fometimes had Pepin-cider better then ordinary, and indeed then they could make again, were beholding to chance for it; either that their Apples were not fo full ripe at that as at other times, and fo not bruifed into fo fmall parts; but the fermentation was ended in the Veffel, and the Lee being then groß fetled before the Cider had fermented fo long as to be hard.

Or elfe, by fome Accident they had not put it fo foon into the $V e f e l$, but that in part it was fetled before they put it up, and the grofleft part of the Lee left out of the Veffel.

Or elfe, the Bung being left open fome part of the pirits evaporated; and that made the fermentation the weaker, and to laft the less time.

Or elfe, they put it up in fuch a feafor that the weather continued cold and frefty till the ferinentation was quite over; and then it having wrought the lefs time, and with the lefs violence; it remained more pleafant and rich then otherwife it would have done.

Now for the time of making Pepin-cider, I chufe to do it in the beginning of November, after the Apples had been gathered and laid about three weeks or more in the loft, that fo the Apples might have had a little time to fweat in the houre before the cider was made, but not too much; for if they be not full ripe before they be gatbered, and not fuffered to lye a while in the beap, the Cider will not be fo pleafant; and if they be too ripe.when they are gatbered, or lye too long in the beap, it will be very difficult to feparate the Cider from the grols Lee before the fermentation be: gins: and in that cafe it will work fo long that when it fincs the Cider will be bard; for. when the Apples are too mellow, they break into fo fmall particles, that it will be long before the Lee fettles by its weight only : and then the fermentation may begin before it be feparated, and fo deftroy your intention of taking away the groß Lee. And if the Apples be not mellow enough; the Cider will not be fo pleafant as it ought to be.

This being faid for the time of making the Pepin-cider, may (mutatis mulandis) ferve for all other forts of Summer-fruit; as the Kentifh-codling, Marigolds, Gilly-flowers, summer-pearmains; Summer-pepins, Holland-pepins, Golden-pepins, and even Winterpearmains. For though they muft not be madeat the fame time of the year, yet they muft be made at the time when each re- 
fpective fruit is in the fame condition that I before directed that the Winter-pepin thould be. Nay, even in the making of that Cider, you are not tied to that time of the year to make your Cider; but as the condition of that particular year hath been, you may make your Cider one, two, three or four weeks later; but it will be very feldom that you hall need to begin to make Kentifbpepin-cider before the beginning of November, even in the moft Soutbern parts of England.

The next thing I hall mention, is, the ordering of your bottles after they are filled; for in that confits no fmall part of caufing your Cider to be in a juft condition to drink: For, if it does ferment too much in the bottle, it will not be fo convenient to drink, neither for the tafte, nor wholfomnefs; and if it ferment not at all, it will want that little fret which makes it grateful to moft $\mathrm{Pa}$ lates. In order to this, you muft obferve, firft, whether the Cider were bottled too early, or too late, or in the juft time : If too ear$1 y$, and that it hath too much of the flying Lee in it, then you muft keep it as cool as you can, that it may not work too much, and if fo little that you doubt it will not work at all, or too little; you muft by keeping it from the inconvenience of the external air, endeavour to haften and increafe the fermentation. And this I do, by fetting it in fand to cool, and by covering the bottles very well with ftraw, when I would haften or increafe the fermentation.

And if I find the Cider to have been bottled in its juft time, then I ufe neither, in ordinary weather; but content my felf that it ftands in a clofe and coole Cellar, either upon the ground, or upon Shelves; faving in the time that I apprehend froft, I cover it with ftraw, which I take off as foon as the weather changeth; and confequently about the time that the cold East winds ceafe; which ufually, with us, is in the beginning of April; I fet my bottles into fand up to the necks. And by this means I have kept Pepin-cider without change till septenber, and might have kept it longer, if my ftore had been greater : For by that time the beats were totally over, and confequently, the canfe of the turn of Cider.

Having now declared what is (according to my opinion) to be done to preferve Cider, if not in it's original fweetnefs, yet to let it lofe as little as is potiible; I thall now fall upon my fifth Affertion, which is, that it is probable that fomewhat like the former Method may in fome degree mend Hard-apple-cider, Perry, or a drink made of the mixtures of Apples and:Pears; and not imporfible that fomewhat of the fame nature may do good to Frenchwines alfo.

Firft, for French-wines, I think what I have in the beginning of this difcourfe declared, as the hint which firt put me upon the conceit, that the over-fermenting of Cider was the caufe that it loft of its original fweernefs (viz. the making of three forts of Wine, of one lort of Grapes) is a teftimony that the firft fort of Wine hath but little of the groß Lee, and confequently, ferments but little, nor lofeth but little of the original fweetnefs; which inl. II makes 
makes it evident that the fame thing will hold in Wine which doth in Cider; but the great difficulty is (if I be rightly informed) that they ufe to let the Wine begin to ferment in the Vat before they put it-into the Hog heads or other Veffels; and thus they do, that the Husks and other Filth (which in the way they ufe, muft neceffarily, be mingled with the Wine) may rife in a skum at the top, and fo be taken off : Now if they pleafe, as foon as it is preffed, to pafs the Wine through a ftrainer, without expecting any fuch purgation, and then ule the fame Metbod formerly preferibed for Cider, Ido not doubt but the grofs part of the - Lee of Wines, being thus taken away, there will yet be enough left to give it afermentation in the bottles, or fecond vefsel, where it thall be left to ftand, in cafe you have not bottles enough to put ux all the Wine from which you have thus taken away the groß Lee.

This Wine I know not whether it will laft fo long as the other ufed in the ordinary way, or not; but this I confidently believe, it will not be fo harfh as the fame would have been if it had been ufed in the ordinary way; and the pleafantnefs of Tafte, which is not unwholfome, is the chief thing which I prefer both in Wine and Cider.

Now for the Hard-apple-cider, that it will receive an improvement by this way of ordering, hath been long my opinion; but this year an accident happened, which made it evident that I was not miftaken in this conjecture. For there was a Gentleman of Herefordhire, this laft Autumn, that by accident had not provided Caskenough for the Cider he had made; and having fix or feven Hoggeads of Cider for which he had no Cask, he fent to Worcefter, Glocefter; and even to Briftol, to buy fome, but all in vain; and when his fervants returned the Cider that wanted Cask had been fome five days in the Vat uncovered; and the Gentleman being then difpatching a Barque for London with Cider, and having neer hand a conveniency of getting Glaß-bottles, refolved to put forne of it into bottles; did $\mathrm{fo}_{\text {, }}$ and filled feven or eight Hampers with the cleareft of this Cider in the Vat, which had then never wrought, not been put into any other $V e f f e l$ but the $V$ at ; the Barque in which his Cider came had a tedious paffage; that is, it was at leaft feven weeks before it came to London, and in that time moft of his Cider in Cask had wrought fo much that it was much harder then it would have been if it had according to the ordinary way lain ftill in the Country, in the place where it was firft made and put up, and confequently, wrought but once.

But the other, which was in Bottles, and efcaped the breaking, that is, by accident, had lefs of the Lee in it then other bottles had, or was not fo hard Itopped, but either before there was force enough from the ferinentation to break the bottle, or that the Cork gave way a little, and fo the air got out; or that the bottles were not originally well corked, was excellent good, beyond any Cider that I had tafted out of Herefordflire; fo that from this Experience I dare confidently fay, that the ufing Hard-apple-cider after the former Method, prefcribed for Pepin-cider, will make it re-

$$
\mathrm{F}_{2} \text { tain }
$$


tain a confiderable part of fweetnefs more then it can do after the Method ufed hitherto in Herefordfhire. Nor do I doubt but my Method will in a degree have the fame effect in Perry, and the drink (as yet without a name that I do know of) which is made of the juice of Wardens, Pears and Apples, by feveral perfons, in feveral proportions; for the Reafon being the fame, I have no caufe to doubt, but the effect will follow, as well in thole Drinks, as in Cider and Wines:

I am now come to my laft Affertion; that Cider thus ufed cannot be unwholfome, but may be done to what degree any mans Palate defires.

rinft, it cannot be unmolfome, upon the fame meafure that ftummed Wine is fo; for that unwholfomenefs is by leaving the caufe of fermentation in the Wine, and not fuffering it to produce its effect before the Wine be drank, and it ferments in mans body : and not only $\mathrm{fo}_{\mathrm{o}}$, but fets other bumours in the body intofermentation; and this prejudiceth their bealth that drink fuch Wines.

Now though Cider ufed in my method thould not ferment at all, till it come into the hottle, and then but a little; yet the caufe of fermentation being in a great degree taken away, the reft can do no confiderable harm to thofe which drink it, being in it felf but little, and having wrought in the bottle before men drink it; nor indeed do I think, nor ever find, that it did any inconvenience to my felf, or any perfon that drank it when it was thus ufed.

secondly, becaufe the difference of menspalates and confitutions is very great; and that accordingly men like or dillike drink that hath more or lefs of the fret in it; and that the confequences in point of health are very different, in the method by me formerly prefcribed : it is in your poner to give the cider juft as much fret as you pleafe, and no more; and that by feverall ways : for either you may bottle it fooner or later, as you pleafe : or you may bottle it from two Taps in your $V e f f e l$, and that from the higher Tap will have lefs fret, and the lower more : or you may bottle your Cider all from one Tap, and open fome of the bottles about a week after for a few minutes, and then ftop them up again; and that which was thus ftop'd will have the lels fret: or, if your $\mathrm{Ci}^{\circ}$ der be bottled all from one Tap, if you will (even without opening the bottles) you may make fome difference, though not fo confiderable as either of the former ways, by keeping part of the bottles warmer, for the firft two moneths, then the reft; for that : which is kept warmeft will have the mont fret. 


\section{Sir PAUL $\mathcal{X}$ EILE'S fecond Paper.}

My Lord,

Napo He Paper which by the Command of the Rojal society . 50 I delivered in the latt year, concerning the order(1. 3 ing of Cider, I have by this years experience found 12. 3 defective in one particular, of which I think fit by clecwores this to give you notice, which is thus: Whereas in the former Paper I mention, that after the Pepin-cider hath ftood 24 hours in the Vat, it might be drawn off into pailes, and fo. put into the Veflel; and that having ftood a fecond 24 hours in that Veffel, it might be drawn into another Veffel, in which it might ftand till it were fit to Bottle; for the particulars of all which proceeding I refer to the former Paper; and thall now only mention, That this laft year we were fain to draw it off into. feveral Veffels, not only as is there directed, twoice, but moft of our Cider five, and fome fix times; and not only fo, but we were after all this fain to precipitate the Lee by fome of thofe ways mentioned by $D$ r Willis in the 7 th Chap. of his Treatife De fermentatione. Now though this be more of trouble then the Method by me formerly mentioned; yet it doth not in the leaft deAroy that Hypotbejis which in the former Difcourfe I laid down, (viz.) That it was the leaving too much of the Lee with the Cider, which upon the change of air, fet it into a new fermentation, and confequently made it lofe the fweetnefs; for this change by the indifpofition of the Lee to fettle this year more then others, hath not hindred the goodnefs of the Cider; but that when it was at laft maftered, and the cider bottled in a fit temper, it was never more pleafant and quick then this year : but I find that this year our Cider of Summer-Apples is already turned fowre, athough it be now but the firft of Fanuary; and the laft year it kept very well till the beginning of March; which makes me fear that our Pepin-cider will not keep till this time twelve moneth, as our Pepin-cider of the laft year doth till this day, and ftill retains its original pleafantnefs without the leaft turn towards fowrenefs.

And I am very confident, the difference of time and trouble; which this year we found in getting the Cider to fine and be in a condition to Bottle, was only the effect of a very bad and wet Summer, which made the Fruit not ripen kindly; and to make it yet worfe, we had juft at the time when we made our Cider, this year, extream wet and windy weather, which (added to the unkindlinefs of the Fruit) was the whole caufe of this alteration : And however my Hypotbefis as yet remains firm, for if by taking any part of the Lee from the Cider you can preferve it in its original fweetners, it is not at all material whether it be always to bedone by twice drawing off from the Lee, or that it muft fometimes 
times be done with more trouble, and by oftener repcating the fame Work; fo that finally it be done, and by the fame means, that is, by taking away part of the Lee, which otherwife would have caufed too much fermentation; and confequently have made the cider lefe part of its original fweetnefs.

My Lord, Ifhould not have prefumed to have given you and the Society the trouble of pirufing this Paper, but that, if poffible, I would have you fee, that what I think an errour in any opinion that I have held; I am willing to own; and yet I defire not that you fhould think my miftake greater then in Reality it.is. 


\section{OBSERVATIONS}

Concerning the

\section{Making and Preferving}

\section{$\mathrm{OF}$}
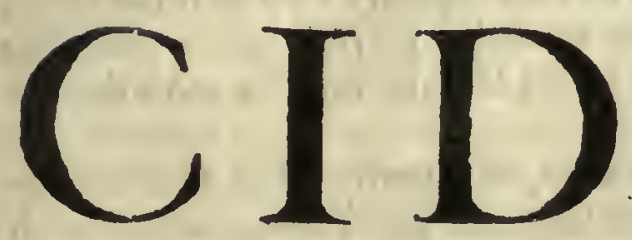

B Y

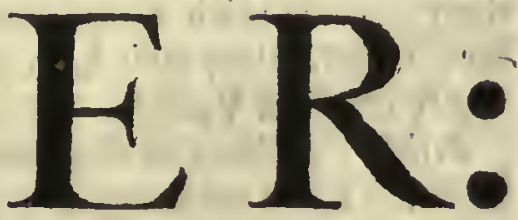

.

\section{ҒOHX NEWBURGH Elq;}

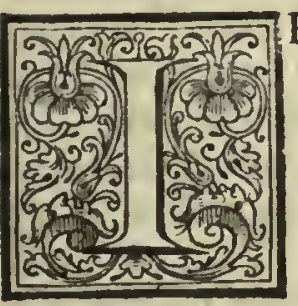

F the Apples are made up immediately from the Tree, they are obferved to yield more, but not fo good Cider, as if hoarded the fpace of a month or fix weeks; and if they contract any unpleafing tafte (as fometimes 'tis confers'd they do) it may be imputed to the Room they lye in, which, if it hath any thing in it either of too fweet or unfavoury fmell, the Apples (as things moft fufceptible of impreffion) will be eafily tainted thereby.

Firft, therefore, ' $T$ is obferved by prudent Fruiterers to lay their Apples upon clean mere made Reeds, till they grind them for Cider, or otherwife make ufe of them : And if, notwithftanding this caution, they contract any rottennefs before they come to the Ciderprefs, the dammage will not be great, if care be had ere the Apples be grownd to pick out the finowed and the black-rotten; the reft, though fomewhat of putrefacticn hath put them into a perifhing condition, will not render the Cider ill conditioned, either in refpect of tafte or duration.

Secondly; If the Apples be abortive, having been (as it ufually happens) thaken down before the time by a violent wind, it is obferved to be fo indifpenfably neceflary that they lye together in hoard, at leaft till the ufual time of their maturity, that the $\mathrm{Ci}$ der otherwife is feldome or never found worth the drinking.

Thirdly, It matters not much whether the Cider be forc'd to purge it felf by working downward in the Barrel, or upwards at the ufual vent, fo there be matter fufficient left, on the top for a 


\section{Aphorifms concerning Cider.}

thick skin or film, which will fometimes be drawn over it, as well when it works after the vulgar manner, as when 'tis prefently ftop'd up, with face left for fermentation, to bciperformed altogether within the Veffel.

Fourthly, No Liquor is obferved to be more eafily affected with the favour of the Veffel then Cider; therefore fingular care is taken by difcreet Cider-Mafters, that the Veffel be not only taftelefs, but alfo well prepared for the Liquor they intend to fill it with. If it be a new Cask, they prepare it by fcalding it with Water, wherein a good quantity of Apple-pomice hath been boyled: If a tainted Cask, they have divers ways of cleanfing it: Some boyl an ounce of Pepper in fo much Water as will fill an Hogfhead, which they let ftand in a Veffel of that capacity two or three days; then wafh it with a convenient quantity of frefo water, fcalding hot, which (they fay) is an undoubted cure for the moft dangerounly infected Veffel.

Fifthly, Others have a more eafie, and perhaps lefs effectual remedy. They take two or three ftones of quick lime, which with fix or feven Gallons of Water they fet on work in the Hogfheads, being clofe ftop'd, and tumbling it up and down till the commotion ceafe, it doth the feat. Of Veffels that have been formerly ufed, next to that which hath been already acquainted with $C i$ der, a White-wine or Vinegar Cask, is efteemed the beft; Claret or sack not fo good. A Barrel to which fmall Beer hath been tennant fuits better with Cider then a ftrong Beer Veffel.

Half a peck of un-ground wheat put to Cider that is harfh and eager will renew its fermentation, and render it more mild and gentle: Sometimes it happens, without the ufe of any fuch means, to change with the seafon, and becomes of fharp and four, unexpectedly benign and plearant.

Sixtbly, Two or three eggs put into an Hog hiead of Cider that is become iharp, and near of kin to Vinegar, lometimes rarely lenefies and gentilizes it.

One pound of broad figgs qit is fufficient to dulcifie an Hog/head of fuch Cider. A little quantity of Muftard will clear an Hoghead of muddy Cider. The fame virtue is afcribed to two or three rotten Apples put into it.

The latter running of the Cider, bottled immediately from the wring, is by fome efteemed for a pure, clear, fmall, well-relifh'd Liquor; but fo much undervalued by them who defire ftrong drinks more then wholefom, that they will not fuffer it to incorporate with the firft running.

seventbly, Cider is found to ferment much better in mild and moift then in cold and dry weather; every ones experience hath taught him fo much in the late frofty feafon; if it had not wrought before, it was in vain to expect its working or clearing then, unlefs by fome of the artificial means prx-mentioned, which alfo could not be made ufe of in a more unfeafonable time.

The beft Cider-fruit with us in this part of Dorfet-fire (lying necr to Bridport) next to Pepin and Pearmain, is a bitter-fweet; or, 
as we vulgarly call them bitter ${ }^{9}$ cale, of which for the firft years Cider very good is made unboyld, for two years keeping; being boyled about an Hoggead to half, it's exceedingly ftrong, but not fo pleafant.

Eightbly, We have few Apples, befides this, that yield good $C i$ der alone; the next to it is a. Deans Apple; and the Pleafantine I think may be mentioned in the third place; neither of which need the addition of other Apples to fet off the rellin, as do the reft of our choiceft fruits; Pepins, Pearmains and Gilly-flowers commixt are faid to make the beft Cider in the world. In Ferfey 'tis a general obfervation, that the more of red any Apple hath in his rind, the more appropriate to this ufe; pale-fac'd Apples they exclude as much may be from their CiderVat. With us'tis an obfervation, that no fweet Apple that hath a tough rind is bad for Ciders.

Muftard made with fack preferves boiled Cider, and fpirits it egregioufly : If you boil cider efpecial care muft be had to put it into the furnace immediately from the wring; otherwife, if it be let ftand in Vats, or veffels, two or three days after the preffure, the beft and moft fpirituous part will afcend and fly away in the vapours when fire is put under it; and the longer your boiling continues, the lefs of goodnefs, or vertue, will beleft remaining in the Cider.

1. One of mine Acquaintance, when a Cbild, hoarding Apples in a box where Rofe-cakes, and other fweet wares were, their Companions found them of fo unfavory tafte, and of fo rank a rellinh derived from that perfumed gear which lay too neer, that even a childifh paiate (that feldom dillikes any thing that looks like an Apple) could not difpenfe with it.

2. A Friend of mine having made provifion'of Apples fôr $\mathrm{Ci}$ der, whereof fo great a part of them were found rotten when the time of grinding them came, that they did as ${ }^{3}$ twere wafh the room with their juice, through which they were carried to the wring, had Cider from them not only paffable, but exceeding good; but not without previous ufe of the prementioned caution; I am alfo affured by a Neighbour of mine, that a Brotber of his, who is a great Cider Merchant in Devonßire, is by frequent experience fo well fatisfied with the harmlefsnefs of rotten Apples, that he makes no fcruple of exchanging with any one that cornes to his Cider-pre $\beta$, a Bufhel of found-apples for the fame meafure of the otber. Herein I fuppofe (if in other refpects they are not prejudicial) he may be a gainer by the neer compreffion of the tainted Fruit; which, as we Ppeak in our Country Phrafe, will go neerer together then the other: His advantage may be the greater, if the conceit which goes currant with them, be not a bottomlefs fancy $;$ that a convenient quantity of rotten Apples mixt with the found is greatly affiftant to the work of fermentation, and notan bly helps to clarifie the Cider.

3. A Neighbour told me, that making a quantity of cider with woird-falls, which he let ripen in the board, neer a moneth interceding the time of their decuffion, and that which nature inten- 
ded for their maturity; his Cider proved very good, when all his Neigbbours (who made up their untimely fruit) as foon as it fell, had a crude, auftere undigefted liquor, not worth the name of Cider.

4. The thick skin, or leathern-coat, the Cider oftentimes contracts as well after it hath purged it felf after the ufual manner, as otherwife, is the fureft prefervative of its fpirits, and the beft fecurity againft other inconveniences incident to this and other like vinous liquors, of which the Devonfhire Cider Merchants are fo fenfible, that befides the care they take, that matters be not wanting for the Contexture of this upper garment by ftopping up the veffel as foon as they have filled it (with the allowance of a Gallon or two upon the fcore of fermentation) they caft in Wheatenbran, or duft, to thicken the coat, and render it more certainly air proof. And I think you will believe their care herein not impertinent, If you can believe a ftory which I have to tell you of its won' drous efficacy: A neer Neigbbour of mine affures me, that his Wife having this year filled a barrel with Mead, which being fomwhat ftrong wrought fomwhat boifteroufly in the veffel, that the good-woman cafting her eye that way accidentally, found it leaking at every chink, which afcribing to the ftrength of the liquor, the thought immediately by giving it vent to fave both the liquor and the veffel; but in vain, both the ftopples being pulled out the leakage ftill continued, and the veffel not at all relieved : till cafually, at length putting in her finger at the top, fhe brake the prementioned film; which done, a good part of the Mead imnediately flying out, left the refidue in peace, and the leakage ceafed. It may feem incredible that fo thin a skin thould be inore coercive to a mutinous liquor then a Barrel with Oaken ribs, and ftubborn hoops. But I ain fo well aftured of the veritablnefs of my Neighbours relation, that I dare not queftion it. The reafon of it let wife men determine.

5. A Friend, and Neighbour of mine, herewith cured a veffel of fo extream ill favour as it was thought it would little lefs then poyfon any liquor that was put inte it.

6. A Neighbour of my acquaintance affured me, upon his credit, that coming into a Parfonage houfe in Devonfire, where he found eleven Hogfseads of Cider, being unwilling to fell what he ne're bought, he was three years in rpending that ftore which the former Incumbent had laid in for him : and it greatly amazed him (as well it night, if he remembred the old Proverb, He mends as fosore Ale in summer) to find the fame Cider which in Winter was almoft as tharpe as Vinegar, in the Summer become potable, and gooul natured liquor.

7. In Devonfhire, where their wrings are fo hugely great that an Hog head or two runs out commonly before the Apples fuffer any confiderable preflure, they value this much what before the other, after the rate which we let upon life-loney (that which after the fame manner drops fweetly out of the comb:) above that which renders not it felf without compreffion. In Jerfey they 
value it at a cromn upon an Hogfhead dearer then the other. (This I take from the relation of one of my Neighbours which fometimes lived in that $I$ fland, which (for Apples, and Cider) is one of the moft famous of all belonging to his Majefties Dominions) yet even upon this, and their choiceft Ciders, they commonly beftow a pail of water to every Hog/head, being fo far (it feems) of Pindars mind, that they fear not any prejudice to their moft excellent $l i$ quors by adafh of that moft excellent Element. Infomuch that it goes for a common faying among them, that if any Cider can be found in their I/land which can be prov'd to have no mixture of water, 'tis clearly forfeited. It feems they are ftrongly conceited that this addition of the moft ufeful Element doth greatly meliorate their Cider, both in refpect of colour, tafte, and clarity.

8. About feven years fince I gave my felf the experience of bitter fcale-cider, both crude, and boiled; I call'd them both to an account at troelve moneths end : I then found the crude Cider feemingly as good, if not better then the boiled: But having ftop'd up the boiled, I took it to task again about ten moneths after; at which time I found it fo exceffively frong, that five perfons would fearcely venture upon an ordinary glafsfull of it. $\mathrm{My}$ Friends would hardly believe but I had beightened it with fome of my pirits: the truth is, I do not remember that I ever drunk any liquor, on this fide $\int$ irits, fo highly ftrong and fpirituous:- But wanting pleafantnefs anfwerable to its ftrength, I was not very fond of my experimext.

9. A Neighbour having a good provent of Purclings (an Apple of choice account with us) making up a good part of them to Cider, expected rare liquor; but it proved very mean and pitiful Cider, as generally we find that to be which is made without mixture.

10. My Diftillations fufficiently inftruct $\mathrm{me}$, that the fame $l i$ quor which (after fermentation hath paft upon it) yields a plentiful quantity of pirit, drawn off unfermented yields nothing at all of pirit. And upon the fame, it is undoubtedly certain, that cider boiled immediately from the'wring hath his fpirits compreft, and drawn into a narrow compafs, which are for the moft part watted and evaporated by late unfeafonable boiling. 

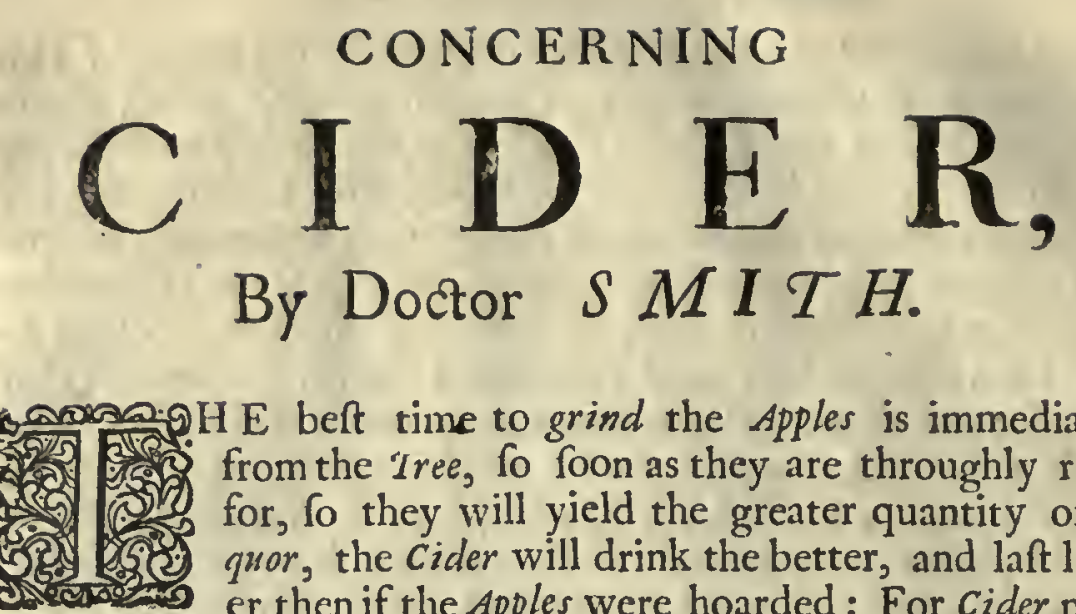

$\mathrm{E}$ beft time to grind the Apples is immediately from the Iree, fo foon as they are throughly ripe: for, fo they will yield the greater quantity of $L i$ quor, the Cider will drink the better, and laft longer then if the Apples were hoarded: For Cider made of hoarded Apples will always retain an unpleafing tafte of the Apples, efpecially if they contract any rottennefs.

The cider that is ground in a stone-cafe is generally accufed to tafte unpleafantly of the Rinds, Stems and Kernels of the Apples; which it will not if ground in a Cafe of Wood, which doth not bruife them fo much.

So foon as the Cidler is made, put it into the Veffel (leaving it about the (pace of one Gallon empty) and prefently ftop it up very clofe: This way is obferved to keep it longer, and to preferve its pirits better then the ufual way of filling the Veffel quite full, and keeping it open till it hath done fermenting.

Cider put into a new Veffel will often tafte of the Wood, if it be pierced early; but the fame ftopped up again, and referved till the latter end of the year, will free it felf of that tafte.

If the Cider be tharp and thick it will recover it felf again : But if harp and clear, it will not.

About Marcb (or when the Cider begins to fparkle in the glafs) before it be too fine, is the beft time to bottle it.

Cider will be much longer in clearing in a mild and moift, then in a cold and dry Winter.

To every Hogflead of Cider, defigned for two years keeping, it is requifite to add (about March, the firft year) a quart of $w$ beat unground.

The beft Fruit (with us in Glocefterfire) for the firft years $C_{i}$ der, are the Red-ftrake; the White and Red Mruft-apple, the fweet and foure Pepin, and the Harvey-apple.

Pearmains alone make but a fmall liquor, and hardly clearing of it felf; but, mixed either with fweet or foure Pepins, it becomes very brisk and clear.

Muft-apple-cider (though the firft made) is always the laft ripe; by reafon that molt of the pulp of the Apple paffeth the ftrainer in preffing, and makes it exceeding thick.

The Cider of the Bronsbury-Crab, and Fox-wbelp, is not fit for drinking, till the fecond year, but then very good.

The Cider of the Eromesbury-crab yields a far greater proportion of pirits, in the difillation, then any of the others.

Crabs and Pears mixed make a very pleafing Liquor, and much fooner ripe then Pears alone.

OF 


\section{O F}

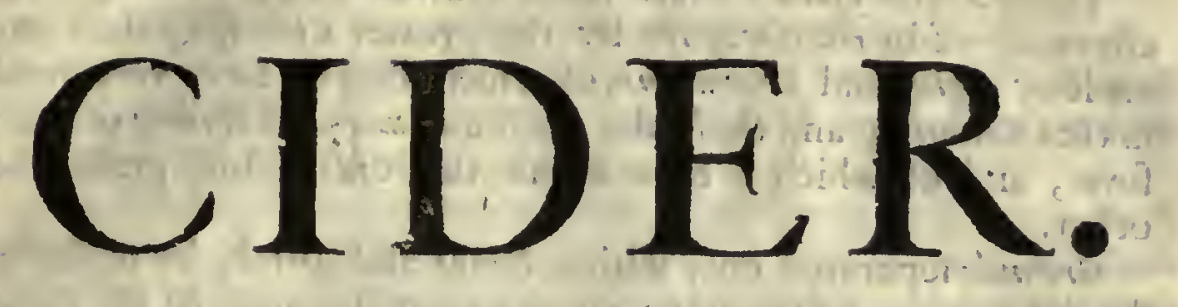

\section{By Capt. $T A Y L O R$}

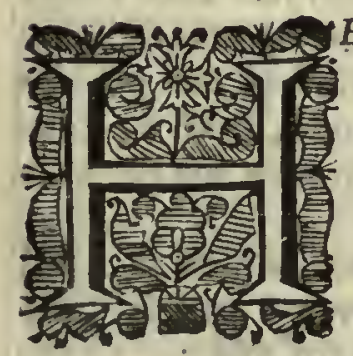

Erefordfire affords feveral forts of cider-apples, as the two forts. of Red-ftrakes, the Gennetmoyle, the summer-violet or Fillet, and the Winter-fillet; with many other forts which are ufed only to make Cider. Of which fome ufe each fort fimply; and others mix many forts together. 'This County is very well ftored with other forts of Apples; as Pepins, Pear. mains, orc. of which there is much Cider made, but not to be compared to the Cider drawn from the Cider-apples; among which the Red-frakes bear the Bell ; a Fruit in it felf fcarce edible; yet the juice being preffed out is immediately pleafant in tafte, without any thing of that reftringency which it had when incorporated with the meat, or fleflo of the Apple. It is many times three moneths before it comes to its clearne $\beta$, and $f(x$ moneths before it comes to a ripenefs fit for drinking; yet $I$ have tafted of it three years old, very pleafant, though dangeroully ftrong. The colour of it, when fine, is of a fparkling yellom, like Canary, of a good full body, and oyly: The tafte, like the Flavour or perfume of excellent Peacbes, very grateful to the Palate and stomach.

- Gennet-moyles make a Cider of a fmaller body then the former, yet very pleafant, and will laft a year. It is a good eating pleafant fharp fruit, when ripe, and the beft Tart-apple (as the Redftrake alfo) beforc its ripenefs. The Tree grows with certain knotty extuberancies upon the branches and boughs; below which knot we cut off boughs the thicknefs of a mans wrift, and place the knot in the ground, which makes the root 3 and this is done to raife this fruit; but very rarely by graffing.

Of Fillets of both fort: (viz. Summer andWinter) I have made Cider of that proportionate tafte and ftrength, that I have deceived feveral experienced Palates, with whom (iimply) it hath paffed for White-wine; and dafloing it with Ked-wine, it hath paffed for Claret; and mingled with the syrupe of Rafp'yes it makes an excellent mamans wine: The fruit is not fo good as the Gennetmoyle to eat: The Winter-fillet makes a lafting Cider, and the 
suminer-fillet an early Cider, but both very ftrong; and the Apples mixt together make a good cider.

Thefe Apples yield a liquor more grateful to my Palate (and fo efteemed of in Herefordflite by the greater Ciderifts) then any made of Pepins and Pearmains, of which forts we have very good in that Country; and thofe allo both summer and Winter of both forts, and of. which Thave drank the Cider; but prefer the other.

Grounds feparated only with a Hedge and Ditch, by reafon of the difference of Soils have given a great alteration to the Cider, notwithftanding the Trees have been graffed with equal care, the fame Graffs, and lantly, the fame care taken in the making of the Cider. This as to the Red-ftrake; I have not obferved the fame nicene $\beta$ in any other fruit; for Gennet-moyles and Fillets thrive very well over all Herefordfoire. The Red-frake delights moft in a fat foil : Hamlacy is a rich intermixt foil of Red-fat-clay and sand '; and Kings-capela low hot fandy ground, both well defended from noxious Winds, and both very famous for the Redfrake-cider.

There is a Pear in Hercford and Worcefterfhires, which is called Barcland-pear, which makes a very good Cider. I call it Cider (and not Perry) becaufe it hath all the properties of cider. I have drank of it from half a year'old to two years old. . It keeps it felf without Roping (to which rerry is generally inclined) and from its tafte: M. Beal, in his little Ireatife called the Herefordflireorcbard, calls it defervingly a Mafculine Drink; becaufe in tafte not like the fweet lufcious feminine juice of Pears. This Tree thrives very well in barren ground, and is a fruit (with the Redfrake) of which Swine will not eat; therefore fitteft to be planted in Hedge-rows.

Red-frakes and other Cider-apples when ripe (which you may know partly by the blacknefs of the Kerriels, and partly by the colour and fmell of the fruit) ought to be gathered in Baskets or Bags, preferved from bruifing, and laid up in heaps in the orchard to Jwe at; covered every night "from the dew: Or elfe, in a Barnfloor (or the like) with fome wheat or Rye-ftraw under them, being kept fo long till you find, by their mellowing, rhey are fit for the Mill.

They that grind, or bruife their Apples prefently upon their gathering, receive fo much liquor from them, that between twenty or twenty two Bufhels will make a Hog Jiead of Cider: but this Cider will neither keep fo well, nor drink with fuch a fragrancy as is defired and endeavoured.

They that keep them a moneth or fix meeks hoarded, allow about thirty bufbels to the making of a Hogfuead; but this hath alfo an inconvenience; in that the Cider becomes not fine, or fit for drinking, fo conveniently as a mean betwixt thefe two will afford.

Keep them then about a fort-night in a board, and order them to be of fuch a caft by this Mellowing; that about twen- 
ty five Bufhels may make a Hogfhead; after which mellowing pro* ceed thus.

I. Pick and clear your Apples from their stalks, leaves, moazi$n e \int s$, or any thing that tends toward rottenness or decay.

2. Lay them before the Stone in the Cider-mill,or elfe beat them fmall with Beaters (fuch as Paviers ufe to fix their pitching) in deep troughs of Wood or Stone, till they are fit for the Prefs.

3. Having laid clean wheat-ftraw in the bottome of your Prefs, lay a heap of bruifed Apples upon it, and fo with fmall handfuls or wijps of ftrain, which by twifting takes along with it the ends of the Straw laid firft in the bottome, proceed with the bruifed Apples, and follow the heaps with your twifted ftram, till it comes to the height of two foot, or two foot and a half; and fo with fome Straw drawn in by troifting, and turned over the top of it (fo that the bruifed Apples are fet as it were into a deep Cheef-vat of ftram, from which the Country people call it their Cider-cheefe) let the board fall upon it even and flat, and fo engage the force of your skrew or l'refs fo long as any Liquor will run from it. Inftead of this Checfe others ufe baggs of Hair-cloth.

4. Take this Liquor thus forced by the Prefs, and ftrain it thorow a ftrainer of hair into a $V a t$, from whence ftraight (or that day) in pails carry it to the Cellar, tunning it up prefently in fuch $V$ efjels as you intend to preferve it in; for I cannot approve of a long evaporation of $\int$ pirits, and then a difturbance after it fettles.

5.Let your $V e \int f e l s$ be very tight and clean wherein you put your cider to fettle: The beft form is the stund or Stand, which is fet

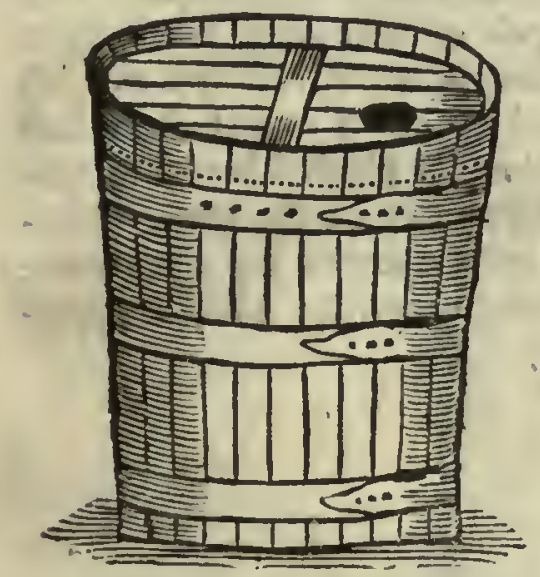
upon the leffer end, friom the top tapering downwards ; as fúppofe the bead to be thirty inches diametre, let then the bottome be but eighreen or twoenty inches in diametre; let the Tun-bole or Bung-hole be on the one fide outwards, toward the top. The reafon of the goodnefs of this form of $V e f f e l$ is, becaufe Cider (as all ftrong Liquors) after fermentation and working, contracts a cream or skin on the top of then, which in this form of Veffel is as it finks contracted, and fortified by that contraction, and will draw frefh to the laft drop; whereas in our ordinary Veffels, when drawn out about the half or middle, this skin dilates and breaks, and without a quick draught decays and dies.

6. Referve a Pottle or Gallon of the Liquor to fill up the Veffel to the brim of the Bung-bole, as oft as the fermentation and working leflens the Liquor, till it hath done its work.

7. When it hath compleated its work, and that the Vefel is filled up to the bung-tole, ftop it up clofe with well mix'd clay, and well tempered, with a handful of Bay-falt laid upon the top of the 
clay, to keep" it moint, and renewed as of as need thall require; for if the clay grows dry it gives vent to the Jpirits of the Liqusor, by which it fuffers decay.

I am againt either the boyling of cider, or the hanging of a bag of spices. in it, or the ufe of Ginger. in drinking it; by which things people labour to correct that mindiness which they fancy to be in it: I think Cider not mindy; thofe that ufe to drink it are moft free from windine 3 ; ; perhaps the virtue of it is fuch, as that once ripened and mellowed, the drinking of it in fuch ftrength combates with that woind which lies infenfibly latent in the body. The Cider made and fold here in London in Bottles may have that mindiness with it as Bottle-beer hath, becaufe they were never fuffered to ferment : But thofe that have remarked the ftrength and vigour of its fermentation, what weighty things it will caft up from the bottome to the top; and with how many bubbles and bladders of wind it doth 200 ork, will belicve that it clears it felf by that operation of all finch injurious qualities.

To preferve Cider in Bottles I recommend unto you my own Experience, which is, Not to bettle it up before fermentation; for that incorporates the mindy quality, which otherwife would be ejected by that operation: This violent fuppreffion of fermentation makes it windy in drinking, (though I confefs brisk to the tafte, and prightly cutting to the Palate:) But after fermentation, the Cider refting two, three, or four Months, draw it, and bottle it up, and fo lay it in a Repofitory of cool Jpringing mater, two or three foot, or more, deep; this keeps the pirits, and the beft of the.pirits of it together: This makes it drink quick and lively; it comes into the glafs not pale or troubled, but bright yellow, with a fpeedy vanilhing nittinefs, (as the Vintners call it) which evaporates with a Sparkling and whizzing noife; And than this I never tafted either Wine or Cider that pleafed better: Info- much that a Noble-man tafting of a Bottle out of the water (himfelf a great Ciderift) protefted the excellency of it, and made with much greater charges, at his own dwelling a mater Repofifitory for his Cider, with good fuccefs. 


\section{Kalendarium Hortenfe:}

OR, THE

\section{Gard'ners Almanac;}

Directing what $\mathrm{He}$ is to do

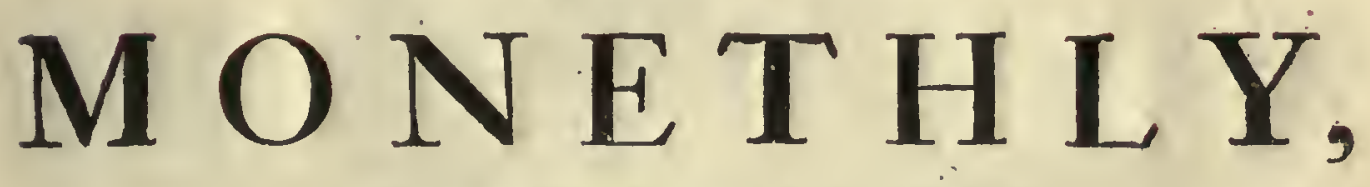

THROUGHOUTT THE
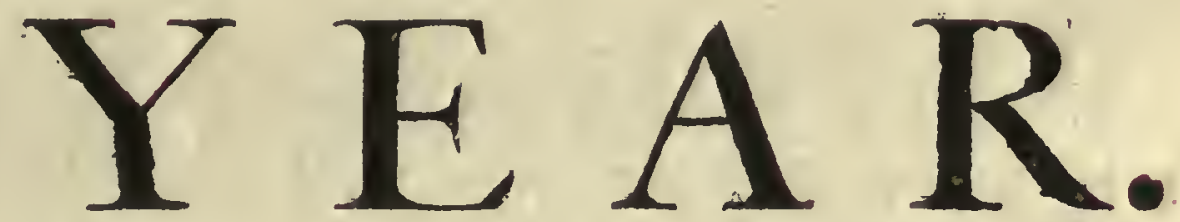

Columella de cult. Hort lib. ro.

Invigilate viri, tacito namitempora greefu

Diffugiunt, nullóque fono convertitur annus.

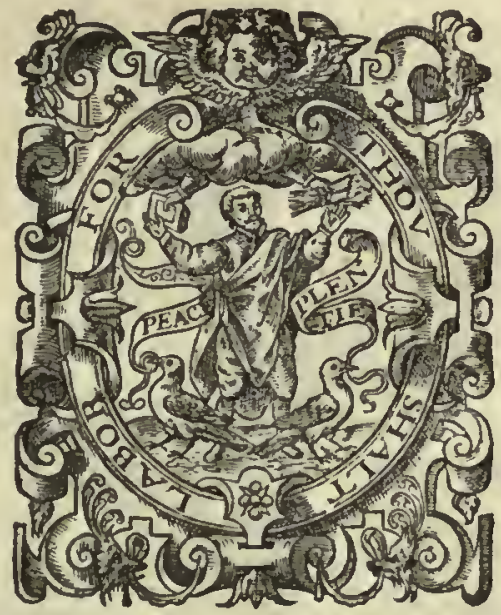

LONDON,

Printed by F. Macock, for Fobn Martin, and Fames Alleftry, and are to be fold at the ir Shop, at the fign of the Bell in S $S^{C} P$ anl's Church-yard. MD CLXIV. 


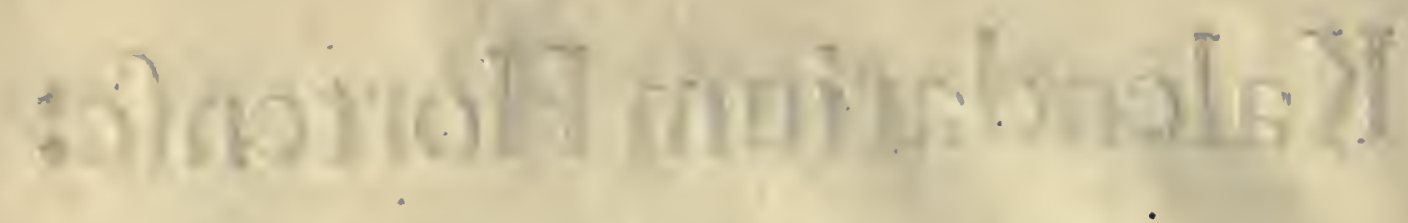
W'ing

postgenild sologhinge?

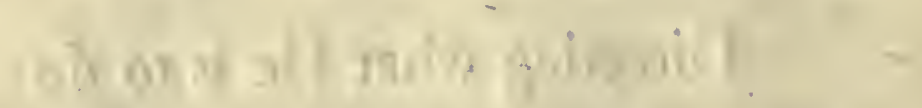

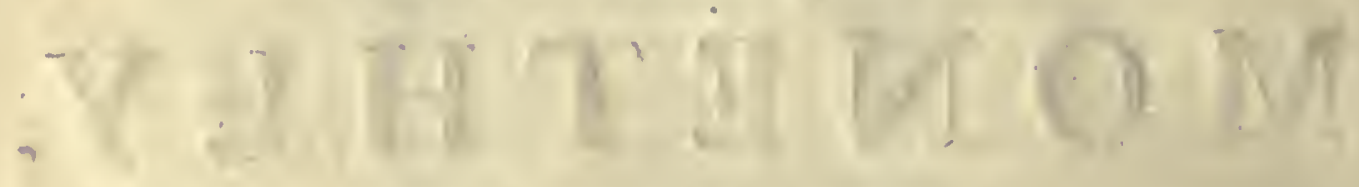

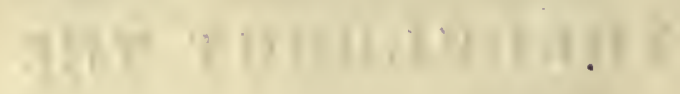
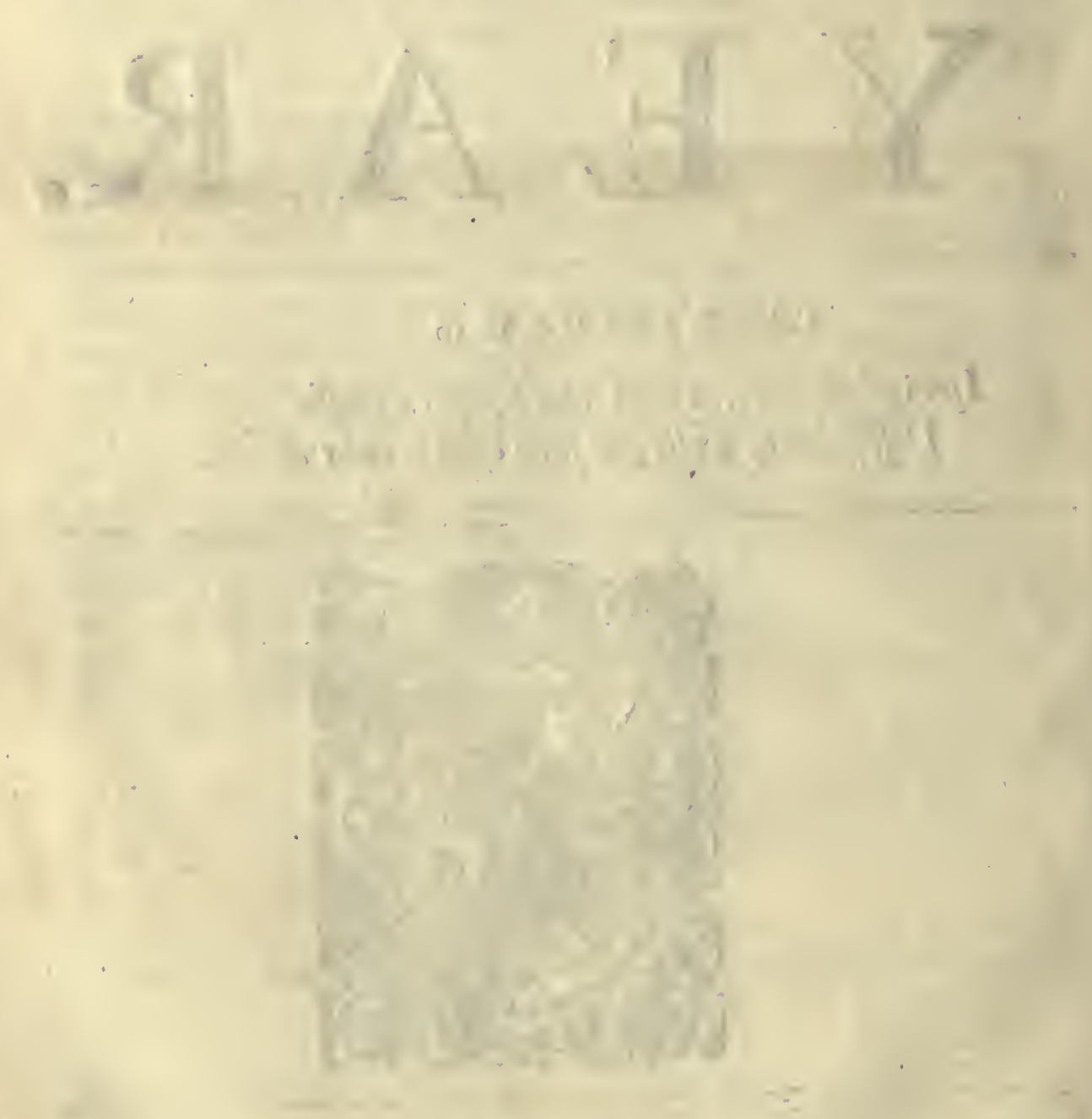

$$
\therefore \sin \cdot i
$$

1. rithe

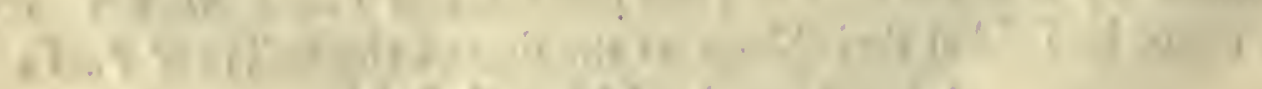

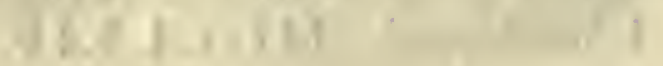




\section{INTRODUCTION}

\section{TO THE}

\section{KALENDAR.}

80. $S$ Paxadife (though of Gods oron Planting) bad not. been Paradife longer then the Man was put into it, to Gen. 2.15. Drefs it and to keep it; fo, nor will our Gardens (as neer as ane can contrive them to the refemblance of that blefsed Abode) remain long in their perfection, unles they are alfo continually cultivated. For wpen we bave fo much celebrated the life and felicity of an excellent Gard'ner; it is not becaufe of the leifure mbich be enjoys above other neen; eafe and opportunity wobich minifters to volupty; and infignificant delights; fuch as Fools derive from Senfual objects : We dare bardily pronounce it: there is not amongst Men a more laborious life then is that of a good Gard'ners; but a labour full of tranquillity, and fatisfaction; Natural and Inftructive, and fuch as (if any) contributes to Piety and Contemplation, Experience, Health and Longxvity. In fum, a condition it is, furnifh'd with the moft innocent, laudable and purest of eartbly felicities, and fuch as does certainly make the neereft approaches to that Bleffed ftate, wobere only they enjoy all things moitbout pains; as thofe who were lead only by the light of Nature, becaufe they could phanfie none more glorious, thought it worthy of entertaining the Souls of their departed Heroes, and moft deferving of Mortals.

But to return to the Labour; becanfe there is notbing excellent which is to be attain'd without it: $A$ Gard'ners work is never at an end: It begins with the Year, and continnes to the next: He prepares the Ground, and then be Sows it; after that he Plants, and then be gatbers the Fruits; but in all the intermedial fpaces be is careful to dreß it 3 so as Columella, $\beta$ peaking of this continual afjidiity, tells us, a Gard'ner is not only to confider pratermiffas duodecim De R. R. horas, fed annum periiffe, nifi fua quaque quod inftat effecerit : li.ix. Quare, neceffaria eft ( $\int a y s$ be) Mentrui cujufque officii monitio ea, qux pendet ex ratione fyderum coll : for fo with the Poet,

- $\ldots$ tan funt Arcuturi Sydera nobis,

Hoedorûmque dies fervandi, \& lucidus anguis;

Quam quibus in patriam ventofa per æquora.vectis

Pontus, \& Oftriferi fauces tentantur Abydi.

Geor. I.

All which duly zeeigh'd, how precious the time is, how precipitous the occafion, how many things to be done in their. juft Seafon, 
and bow intolerable a confufion will fucceed a gmall neglect, after once a Ground is in order, we thought we foould not attempt an unacceptable Work, if here we endenvour to prefent our Gard'ners with a compleat Cycle of what is requifite to be done throughout cvery Moneth of the Year: We fay, each Moneth; becaufe by dividing it into Parts so diffind, the Order in wobich they foall find each particular dispos ${ }^{3}$, may not only render the work more facile and delightfome; but redeem it from that extream confufion, which for want of a conftant, and uniform Method, we find does jo vniverfally diftract. our ordinary fort of Gard'ners. They know not (for the moft part) the Seafons woben things are to be done; and when at any time they come to know, there often falls out fo many things to be done on the fudden, that fome of them muft of necefity be neglected for that whole Year, whicls is the greatcft detriment to this Myftery, and frequently irrecoverable. Well therefore did the experienc'd Columella put bis Gard'ner in mind of the fugacioufnes of the Seafons, and the nece) Sity of being Induftrious, where be thus be peaks the men of our. Profellion.

Invigilate viri, tacito nam tempora greffu Diffugiunt, nulloque fono convertitur annus.

Colum. de cult. Hort. lib. 10.

Colide R. $R$. the Moon: In hac autem Ruris difciplina non defideratur ejufmo-

Be watchful Sirs, the Seafons hafte them out,
And without noife the Year is whirl'd about.

We are yet far from impoling (by any thing we bave alledg'd concerning the fe Menftrual Periods) thofe nice and hypercritical Puntillos which fome Aftrologers, and fuch as purfue their Rules, feem. to oblige our Gard'ners to; as if, forfooth, all were loft, and our pains. to no purpoje, unless the Sowing and the Planting, the Cutting and the Pruning, were performid in fuch and fuch an cxact minute of: di fcrupulofitas. There are indeed fome certain Seafons, and fufpecta tempora, which the prudent Gard'ner ought carefully (as much as in bim lies) to prevent: But as to the reft, it forll be Jufficient that be diligently follow the Obfervations which (by great Induftry) we bave collected together, and here prefent bimz, as fo many Synoptical Tables calculated for his Monethly $u f e$, to the end he may pretermit nothing which is under bis Infpection, and is neceffary ; or diftradt bis Thoughts and Employment before the Seafons require it. And now, bowever This may feem but a Trille to fome mbo efteem Books by the bulk, and not the benefit; let them not yet defpife the e few enfuing Pages: For never was any thing of this pretence fo fully and ingenuoufly imparted, I foall not fay to the regret of all our Mercenary Gar'dners, because I bave much obligation to fome above that

-1 Epithete; MrRofe, Gard'ner at Effex-Houfe to Her Grace the Duchefs of somerfet, and $M$ r Turner, formerly of Wimbleton in Surrey; who being certainly amongt the moft expert of their Profeffion in England, are no lefs to be celebrated for their frec com- 
munications to the Publick, by divers Notes of theirs, which have furnifid to this Defign. And it is from the Refult of very much Experience, and an extraondinary inclination to cherifh fo innocent and landable a diverfion, and to incite an Affection in the Nobles of this Nation tomards it, that I begin to open to them fo many of the Secrets, and mogt precious Rules of this Myfterious Art, woithout Impofture, or invidious Referve. The very Catalogue of Fruits, and Flowers, for the Orchard and the Parterre, will gratifie the mogt innocent of the Senfes, and whoever elfe foall be to feek a rare and univerfal choice for his Plantation: But this is enough.

Touching the Method, it is fo obvious that there needs no farther direction; and the Confequent will prove fo certain, that a Work of the bufieft pains is by this little Inftrument rendred the moft facile and agreeable, as by which you Shall continually preferve your Garden in that perfection of beauty and luftre, mithout confufion or prejudice: Nor indeed could we think of a more comprebenfive Ex-pedient, whereby to alsyt the frail and torpent Memory through fo multifarious and numerous an Enployment (the daily fubject of $a$ ? Gard'ners care) then by the Oeconomy and Difcipline into which. soe bave bere refolv'd it, and which our. Induftrious. Gard'ner may bimfelf be continually. Improving from bis own Obfervations and Experience.

This Kalendar might be confiderably angmented, andrecommend it. felf to a more Univerfal ufe, by taking in the Monethly Employments of all the parts of Agriculture, as they bave been begun to. zs. in Columella, Palladius; de Serres, Auguftino Gallo, our Mark-Col. de R. $R$. ham, and others; especially if well and judicioully applied to our lib.1 r.ca.11. Climate and feveral Countries: but it rere here befides our Infti- Pall. lib. $x$. tution, nor would the Pages contain them; what is yet found Tit.1. vacant bas beez purpofely left, that our Gard'ner may fupply as be finds canfe; for which reafon likewife we bave rang'd both the Fruits. and Flowers in Prime after fomwhat a promifcuous Order, and not after the letters of the Alphabet, that the Method might be purfi'd with the leaft diforder. Laftly,

The Fruits and Flowers in Prime are to be as well confidered in relation to their lafting and continuance, as to their maturity and beauty. 


\section{Kalendarium Hortenfe.}

Note that for the Rifing and Sering of the Sun, and Length of the Day:s I compute from the firft of every Moneth, London Elevation.

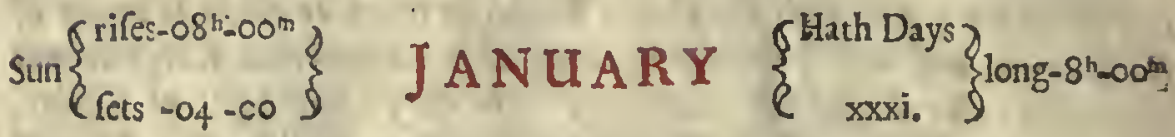

$$
\begin{aligned}
& \text { To be done }
\end{aligned}
$$

Reneb the Ground, and make it ready for the spring : pre1 parealfo soil, and ufe it where you have occafion: Dig Borders; \& c. uncover as yet Roots of Trees, where Ablaquieation is requilite.

Plant 2uick-fets, and Tranfplant Fruit-trecs, if not finifh'd: Set Vines; and begin to prune the old: Prune the branches of orchard-fruit-trees; Nail, and trim your Wall-fruit, and Epaliers.

Cleanfe Trees of Moß, \& c . the Weather moift.

Gather Cyons for Graffs before the buds fprout; and about the Hater end, Graff them in the Stock: Set Beans, Peafe, \&uc.

Sow alfo (if you pleafe) for early Colly-flowers.

So Chervil, Lettuce, Radifh, and other (more delicate) Sallitings; if you will raife in the Hot-bed.

In over wet, or hard weather, cleanfe, mend, fharpen and prepare Garden-tools.

- Turn up your Bee-bives, and fprinkle them with a little warm and fweet Wort; do it dextrouly.

Fruits in Prime, and yét lasting.

$$
\text { … Apples. }
$$

K Entifh-pepin, Rufet-pepin, Golden-pepin, French-pepin, KirtonI pepin, Holland-pepin, Fohn-apple, Winter-2ueening, Marigold, Harvey-apple, Pome-mater, Pome-roy, Golden-Doucet, Reineting, Lones-pearmain, Winter-Pearmain, dic.

Pears.

Winter-Musk (bakes well) Winter-Norwich (excellently baked) Winter-Bergamot, Winter-Bon-creftien, both Mural: the great surrein, $\mathrm{d}$ c. 
Sun $\left\{\begin{array}{l}\text { riles }-08^{\mathrm{b}}-00^{\mathrm{m}} \\ \text { rets }-04-00\end{array}\right\}$

JANUARY

$\left\{\begin{array}{c}\text { Hath Days } \\ \text { xxxi. }\end{array}\right\}^{\text {loug-8h-00t }}$

To be done

In the Parterre, and Flower-Garden.

CEt up your Traps for Vermin; efpecially in your Nurferies of Kernels $S$ and stones, and amongt your Bulbows-roots : About the middle of this Moneth, plant your Anemony-roots, which you will be fecure of, without covering, or farther trouble: Preferve from too great, and continuing Rains (if they happen) snow, and Froft, your choiceft Anemonies, and Ranunculus's fow'd in September or Oafbber for earlier Flowers: Alfo your Carnations, and fuch seeds as are in peril of being wafh'd out, or over chill'd and frozen; covering them with fhuts and fselter, and ftriking off the snow where it lies too weighty; for'it certainly rots, and burfts your early-fet Anemonies and Ranunculus"s, Guc. unlers planted now in the Hot-bed; for now is the Seafon, and they will flower even in London. Towards the end, earth-up, with frefh and light mould, the Roots of thofe Auriculas which the frofts may have uncover ${ }^{3}$; filling up the chinks about the fides of the Pots where your choicef are fet : but they need not be hows' $d$; it is a hardy Plant.

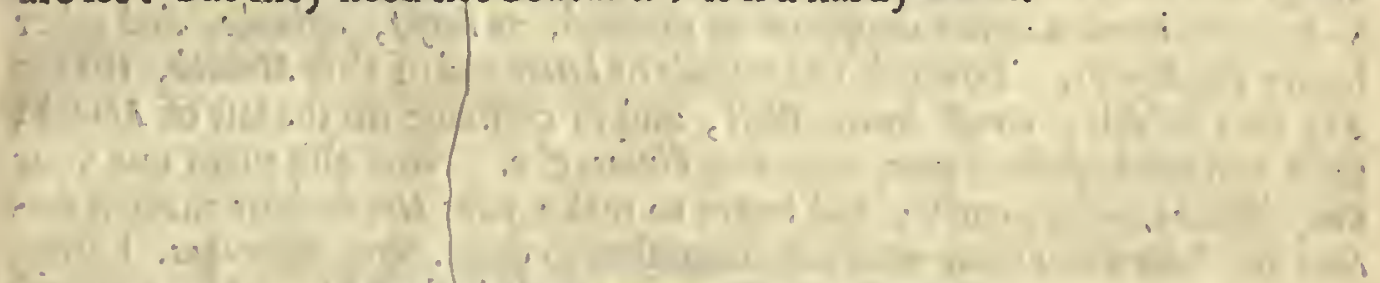

Flowers in Prime, or yet lafting.

TT Inter-Aconite, fome Anemonies, Winter-Cyclamen, Black-Hellebor, Brumal-Hyacinth, Oriental-Facynth, Levantine-NarcifJus, Hepatica, Prim-rofes, Laurus-tinus, Mezereon, PrecoceTulips, duc. 'efpecially, if rais'd in the (Hot-bed.)

Note,

That both thefe Fruits, and Flowers, are more early, or tardy, both as to their prime seafons of eating, and perfection of blowing, according as the soil, and Situation are qualified by Nature, or Accident. Note alfo,

That in this Recenfion of Monetbly Flowers, it is to be underftood for the whole period that any flower: continues, from its firft appearing; to its final withering. 
Sun $\left\{\begin{array}{l}\text { rifer- }-0 j^{\mathrm{h}}-1 ;^{\mathrm{m}} \\ \text { Crets }-04--45\end{array}\right\}$

F

\author{
FEBRUARY
}

$\left\{\begin{array}{l}\text { Hath Days } \\ \text { xxviii. }\end{array}\right\}$ long-og"-2

To be done

In the Orcluard and Olitory-Garden.

Dune Fruit-trecs, and Vines, as yet. Remove Graffs of former years Graffing. Cut and lay 2uick-ets. Yet you may Prune fomeWall-fruit (not finifh'd before) the moft tender and delicate: But be exceeding careful of the now turgid buds and bearers; and trim up your Palifade Hedges, and EßPaliers. Plant Vines as yet, other Shrubs, Hops, Ouc.

Set all forts of Kernels and ftony Seeds. Alfo fow Beans, Peafe, Radifh, Parfneps, Carrots, Onions, Garlick, \&cc. and plant Potatoes in your worft ground.

Now is your Seafon for Circumpolition by Tubs or Baskets of Earth, and for laying of Eranches to take root. You may plant forth your Cabbage-plants.

Rub Moss off your Trees after a foaking Rain, and fcrape and cleanfe them of Cankers, \& c. draining away the wet (if need require) from the too much moiftned Roots, and earth up thofe Roots of your Fruit-trees, if any were uncover'd. Cut off the Webbs of Caterpillats, \& cr. (from the Tops of Tmigs and Trces) to burn. Gather Worms in the Evinings after Rain.

Kitchen-Garden herbs may now be planted, as Parfy, Spinage, and other hardy Pot-bearbs. Towards the middle or latter end of this Moneth, till the Sap rifes briskly, Graff in the Cloft, and fo continue till the laft of March; they will hold Apples, Pears, Cherries, Tlums, \&uc: Now alfo plant out your Colly-flowers to have early; and begin to make your Hot-bed for the firft Melons and Cucumbers; but truft not altogether to them. Sow Apparagus. Laftly,

Half open your paffages for the Bees, or a little before (if weather invite;) but continue to feed weak stocks, occ.

Fruits in Prime, or yet lafting.

Apples.

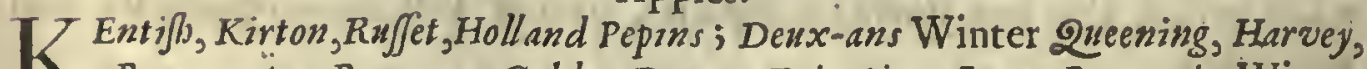
K Pome-water, Pome-roy, Golden Doucet, Reineting, Lones Pearmain, Winter Pearmain, \&c.

$$
\text { - Pears. }
$$

Bon-Chreftien of Winter, Winter Poppering, Little Dagobert, \&c. 


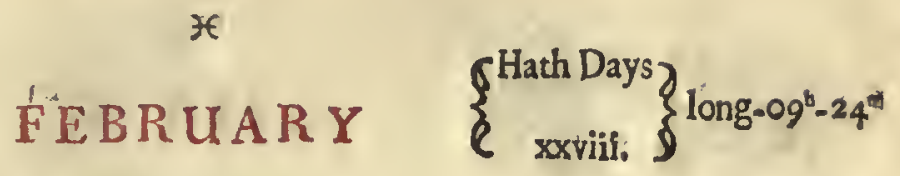

Sun $\left\{\begin{array}{l}\text { rifes-0 } 7^{\mathrm{h}}-13^{\mathrm{m}} \\ \text { frets-04- }-045_{-4}\end{array}\right\}$

To be done

In the Parterre and Flower-Garden:

Ontinue Vermine Trapps, \&c.

(Sow Alaternus feeds in Cajes, or open beds; cover them with thorns; that the Poultry fcratch them not out.

Now and then air your Carnations, in warm days efpecially, and mild ßowors.

Furnilh (now towards the end) your Aviarys with Birds before they couple, ouc.

\section{Flowers in Prime, or yet lafting.}

TT Inter Aconite, fingle Anemonies, and fome double, Tulips precoce, Vers - nal Crocus, Black Hellebore, fingle Hepatica, Perfian Iris, Leucoium,Dens Caninus three leav'd, Vernal Cyclamen white and red, Yellow Violets with large leaves, early Daffodils, \&x. 


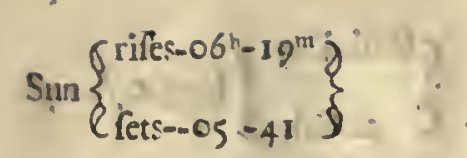

\author{
$r$ \\ MARCH

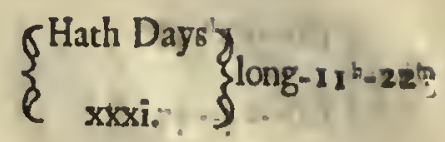

\section{To be done}

\section{In the Orchard, and Olitory-Garden.} Et stercoration is feafonable, and you thay plant what Trees are left,
choigh it be fomething of the latelt, unlets in very backward or moijt
places.

.2 Now is your chiefelt and beft time.for raifing on the Hot-bed Melons, $\mathrm{Cu}$ cumbers, Gourds, b'c. which about the fixth, eighth or tenth day will be ready for the Seeds; and eight days after prick them forth at diftances, accord. ing to the Method, \& $c$.

If you will have them later, begin again in ten or twelve days after the firft; and fo a third time, to make Experiments.

Graff all this Moneth, unlefs the spring prove extraordinary forwards.

You may as yet cut 2uick-Jets, and cover fuch Tree-roots as you laid bare in Autumn.

Slip and fet Sage, Rofemary, Lavender, Thyme, drc.

Sow in the beginning Endive, Succory, Leeks, Radif, Beets, Chard-Beet, Scorzonera, Parfnips, skirrets, Parfley, Sorrel, Bugloss, Borrage, Chervil, sellery, smalladge, Alifanders, \& c c. Several of which continue many years without renewing, and are moft of them to be blanch'd by laying them under litter and earthing up.

Sow alfo Lettuce, onions, Garlick, Orach, Purfan, Turneps (to have early), monethly Peafe, $\mathcal{C} c$. there annually.

Tranfplant the Beet-chard which you fow'd in Auguft, to have moft ample chards.

Sow alfo Carrots, Cabbages, Creffes, Fennel, Majoran, Bafil, Tobacco, Juc. And tranplant any fort of Medicinal Hearbs.

Mid-Marcb drefs up and tring your stramberry-beds, and uncover your Aparagus, f preading and loofning the Mould about them, for their more eafie penetrating: Alfo may you now tranfplant A]paragus roots to make new Beds.

By this time your Bees fit; keep them clofe Night and Morning, if the weather prove ill.

Turn your Fruit in the Room where it lies, but open not yet the windows.

Fruits in Prime, or yet lafting.

Apples.

Clden Ducket, [Doucet] Pepins, Rcineting, Lones Pearmain, Winter PearI main, John Apple, doc.

Peārs.

Later Bon-Chrestein : Double Blofjom Pear, \&c. 


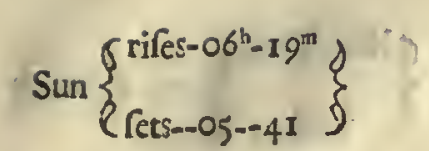

MAR C.H $\left\{\begin{array}{c}\text { Hath Days } \\ \text { xxxi: }\end{array}\right\}$ long $-11^{\mathrm{b}}-22^{\mathrm{m}}$

\section{To be done}

\section{. In the Parterre and Flower-Garden.}

$S^{T}$ Take, and binde up your weakeft Plants and Flowers againft the Windes, before they come too fiercely; and in a moment proftrate a whole sears labour.

Plant Box, $\mathbb{W}_{c}$. in Parterres. Sow Pinls, Sweet-Williams, and Carnations, from the middle to the end of this Moneth. 'Sow Pine-kernels, Firr-Geeds, Bays, Alaternis, philyrea, and moft perennial Greens, \&c. Or you may ftay till fomwhat later in the Moncth. Sow Auriculafeeds in pots or cafes, in fine willow earth, a little loamy; and place what you fow'd in Otzober now in the Shade, and waler. it.

Plant fome Anemony'roots to bear late; and fucceffively; efpecially in, and about Lmadon, where the Smoak is any thing tolerable; and if the Seafon be very diy, nuter them wcll onse in troo or tbrec days. Fibrous roots may be tranfplanted about the middle of this Moncth; fuch as Hepatica's, Primerofes, Auricula's, C'nmmomile, Hyacintb Tuberofe, Matricaria, Hollebor and other Summer Flowers; and towards the end Convolvulu's, Spanifh or ordiniary Jalmine.

Towards the milddle, or latter end of Marcls fow on the Hot-bed fuch Planis as are late bearing Flowers or Fruit in our Climate; as Balfamine, and Balsamum mas, Pomum Amoris, Datura, Atblopic Apples, fome choice Amaramıus, DaEiyls, Geranisum's, Hedyjarum Clipeatum, Humble, and Senfitive Plants, Lentifcus, Myrtle-berries (fteep'd a while), Capficum Indicum, Canna Indica; Flos Africanus, Mirabile Peruian: Nufturtium Ind: Indian Phafenli, Volubilis, Mrrb, Carrobs, Maracoc, five Flos Paffonis, and the like rare and exotic Plants. which are trought us from bot Countries. Note, That the Nuffurtium Ind. African Mary golds, Volubilis snd fonte others, will come (though not altogether fo forwards) in the Cold-bed without Art: But the reft require much, and conftant beat, and therefore feveral Hot-beds, "till the common earth be very warm by the advance of the $S u n$, to bring them to a due ftarure, and perfect their Sceds.

About the expiration of this Mincth carry into the fbade fuch Auriculas, Seedlinge, or plants as are for their choicences referv'd in Pots.

Tranflant al io Carnation feedlings, giving your Layers frefh earth, and fetting them in the Bade for a week, then likewife cut off all the fick and infeeted leaves.

Now do the farewell-frofts, and Eafterly-zrinds prejudice your choiceft Tulips, and fiot them; therefore cóver fuch with $M I$ its or Camias to prevent freckles, and fomeines deftruction. The fame care have of your moft precious Ancmonies, Auricula's, Chama-iris, Brizinal $\mathrm{F}_{\mathrm{a}} \mathrm{a}$ cyntbs, early Cyclamen, \&oc. Wrap your hom Cypress tops with Straw wifss, if the Ealtern blafts prove very tediuns. About the end uncover fume Planis, but with Cauticn; for the tail of the Frolts yet continuing, and fharp roindes, with the.fidden darting heat of the Sun, fcorch and deftroy them in a moment; and in firh weatber neither fow, 1ror tran $\beta$ lamt.

Sow $S$ tock-gilly-fower-feeds in the Full to produce double flowers.

Now may youl fet your Oranges, Lemmans, Mjrtils, Olcanders, Lentifcs, Dates, Alnes, Amna mums, and like tender Trees and Plants in the Portico, or with the windows, and dors of the $G r e c n$-boufes and Confervatories open for eight or ten days before $A$ pril or earlicr, if the $S_{e a f o n}$ invite, to acquaint them gradually with the Air; but truft not the Nighis, unlefs the weather be thorowly fetled. - Laftly,

Bring in materials for the Birds in the Aviary to build their Neffs withail.

$$
\text { Flowers in Prime, or yet lafting. }
$$

A Nemonies, Spring Cyclamen, Winter Aconite, Crocus, Bclis, white and black Heliebnr, finA gle, and double Hepatica, Lerenion, Chamze-iris of all colours, Dens Caninus, Violcts, Fritillaria, Chclidonium fmall with double Flower, Hermodaciyls, Tuberous Iris, Hacinib Zeboin, Brumal, Oriental, \&c. Funquils, great Chalic.'. Dutch Mezercor, Perfian Iris, Auricula's, Narcifus with large tufts, common, double and fingle. Princrnfes, Pracoce Tulips, Spanijh Trumpets or Funquilies; Violets, yellow DuichViolets, Crown Imperial, Grape Flowers, Almonds and Peacb-blodimis, Rubus odoratis, Arbor Fude, brc. 
$\operatorname{Sinn}\left\{\begin{array}{l}\text { rifes-0.05 }-18^{\text {in }} \\ \text { rets-.05 }-4.2\end{array}\right\}$

$\gamma$

\section{A PR IL.}

$\left.\left\{\begin{array}{c}\text { Hath Days } \\ \text { xxxi. }\end{array}\right\}\right\}^{\text {long-1 } 3^{\mathrm{h}}-2 \mathbf{3}^{\mathrm{m}} \mathrm{i}}$

To be done

In the Orchard, and Olitary Garden.

SOw fweet Majoran, Hyfop, Baflle, Thyme, Winter-Savory, Sciurvey-graß, $S$ and all fine and tender Seeds that require the Hot-ked.

Sow alfo Lettuce, Purflan, Caully-flower, Radifh, \&c.

Plant Artichock-flips, \&c.

Set French-beans, \&c.

You may yet flip Lavander, Thyme, Rofe-mary, \&c.

Towards the middle of this moneth begin to plant forth your Melons, and Cucumbers, and fo to the liter end; your Ridges well prepar'd.

Gather up Worms, and snails, after evening fowers, continue this alfo after all Summer-rains.

Open now your Bee-bives, for now they batch; look carefully to them; and prepare your Hives, boc.

Fruits in Prime, and yet lasting.

Apples. DEpins, Deuxans, Weft-berry-apple, Ruffeting, Gilly-flowers, ; Hat Rei-
net, \&cc.

Pears.

Later Bon-creftien, Oak-pear, Euc, double Bloffom, Euc. 


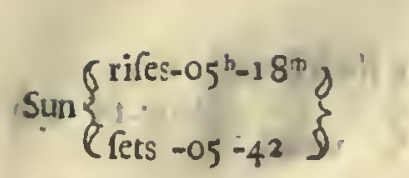

\author{
$\gamma$ \\ A P R I L

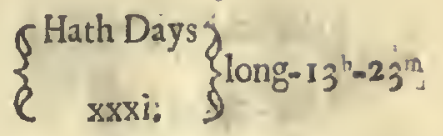

\section{To be done}

\section{In the Parterre, and Flower.Garden.}

$\mathrm{O}^{\mathrm{Q}}$ Qw divers Annuals to have Flowers all Summer; as double Mariagolds, Cyanus of all forts, Candy-tufis, Garden Panly, Mufcipula, Scabious, \&c.

Continue new, and frefh Hot-beds to entertain fuch exotic plants as arrive not to their perfection without them, till the Air and common-iartb be qualified with fufficient warmib to preferye them abroad: A Catalonue of thefe you have in the former Moneth.

Tranfplant fucl Fibrous rriots as you had not finilh'd in March; as Violets, Hepatica, Primrofes, Hellebör, Mitricaria, \&c.

Sow Pinks, Carnations, Sweet-IVilliams, \&c. to flower next year: this after rain.

Set Lupines, \&c.

Sow alfo yet Pine-kernels, Firr-feeds, Pbilyrea, Alaternus, and moft perennial Greens.

Now take out your Indian Tuberofes, parting the Off-fets (but with care, Ieft you break their fangs) then pot them in nitural (norforc'd) Earth; a layer of ricb mould beneath, and about this natural eartb to nourith the fibers, but not fo as to touch the Rulbs: Then plunge your pots in a $H \cdot$-lied temperately warm, and give them no water till they $\beta$ ring, and then fet them under a South-wali: In dry weather water them freely, and expect an incomparable flower in Auguft: Thus likewife treat the Nurcifus of Fapan, or Garnfey-Lilly for a later flower, and make much of this precious Direction.

Water Anemonies, Ranunculus's, and Plants in Pots and Cafes once in two or three days, if drouth require it. But carefully protect from violent ftorms of Rain, Hail, and the too parching darts of the Sun, your Pennacb'd Tulips, Ranunculu's, Anemonies, Auricula's; covering them with Mattrefles fupported on cradles of boops, which have now in readiners. Now is the Seafon for you to bring the choice and tender Jbrubs, orc. out of the Confervatory; fuch as you durft not adventure forth in March : let it be in a fair day; only your Orange-trees may remain in the boufe till May, to prevent all danger.

Now, towards the end of April, you may Tranjiant, and Remove your tender Grubs, orc. as Spanifh Fafmines, Myrtils, Oleanders, young Oranges, Cyclamen, Pomenranats \&c. but firft let them begin to $\beta$ rout ; placing them a fort-night in the fhade: but about London it may be better to defer this worktill mid-Auguft, Vide alfo May: Prune now your Spanifh 7 afmine within an incb or two of the flock; but firft fee it begin tofhoot. Mow Carpet-malks, and ply $W_{\text {eeding, }}$ \&c.

Towards the end (if the cold woinds are paft) and efpecially afterfhowers, Clip Pbilyrea, Ala. ternus, Cypreß, Bux, Myrtils, Burba Fovis, and other tonfile Thrubs, $\mathrm{Cr}_{\mathrm{i}}$.

\section{Flowers in Prime, or yet lafting.}

A Nemonies, Ranunculus's, Auricula Urfi, Cbame-Iri, Cronon Imperial, Caprifolium, Cycla* A men, Dens Caninus, Fritillaria, double Hepatic's, Facyntb ftarry, double Daifies, Florencen Iris, tufted Narcifus, white, double and common, Englif double : Prime-rnfe, Con-flips, Pul fatilla, Ladies-Jmock, Tulips medias, Ranunculus's of 'Tripoly, white Violets, Musk-Grape-flower, Parietaria Luea, Lencoium, Lillies, Pronies, double 7 onquils, Mufcaria revers'd, Cocblearia, Periclymenum, Acanthus, Lilar, Role-mary, Cherries, Wall-pears, Almonds, Albricots, Peacbes, Wbitc-tborn, Arbor Fude blofloming, \&c. 


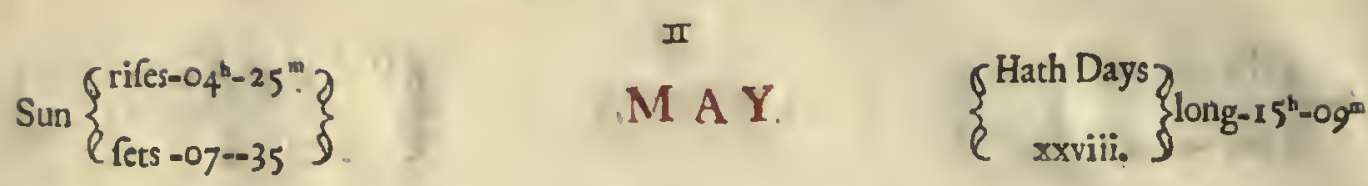

To be done

In the Orchard, and Olitory-Garden.

COw sweet-Majoran, Bafl, Thyme, hot and Aromatic Herbs and Plants $\checkmark$ which are the moft tender.

Sow Purflan, to have young : Lettice, large-fided Cabbage, painted Beans, \&c.

Look carefully to your Mellons; and towards the end of this Moneth, forbear to cover them any longer on the Ridges either with Straw, or Mat-

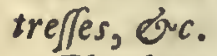

Ply the Laboratory, and diftill Plants for Waters, spirits, Guc.

Continue $W$ eeding before they run to Seeds.

Now fet your Bees at full liberty, look out often, and expect swarms, duc.

\section{Fruits in Prime, or yet lafting.}

Apples.

DEpins, Deuxans or Jobn-apples, Weft-berry-apples, Ruffeting, Gilly-flowerapples, the Adaligar, \&c. Codling.

\section{Pears.}

Great Kairville, Winter-Bon-Cretienne, Double-Bloffom-pear, \&c.

Cherries, \&uc.

The May-Cherry. Stram-berries, \&c. 


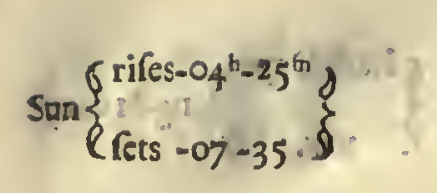

\author{
II \\ M A Y \\ $\left\{\begin{array}{l}\text { Hath Days } \\ \text { xxxi. }\end{array}\right\}^{\text {long-I } 15^{h}-09^{\text {th }}}$
}

\title{
To be done
}

\section{In the Parterre, and Flower-Garden.}

T.w bring your Oranges, tr. boldly but of the Conjervatory; 'tis your only Seafoin to Iranßlant, and Remove, them: let the Cafes be fill'd with natural-earth (fuch as is taken the firfthalf $\beta$ it, fron juft under the $T$ urf of the beft Pafture ground) mixing it with one part of rotten Cowo-dung, or yery mellow Soil-fereen'd and prepar'd fome time before; If this be too ftiff fift a litcle Lime dircreetly with it: Then cutting the Rosts a little, efpecially at bottom; ret your Plint; but not too deep; rather let fome of the Roots appear: Laftly; fettle it with temperate walci (not too much) having fut fome rubbigh of Brick=bats, Isime: ftenes, fbells, or the like at the botton of the Cajes, to make the moiffure paffage, and keep the earth loofe: Then fet them in the jhade for a fort-night, and afterwards expofe them to the Sun.

Give now alfo all your bous'd-plants frefle eartb at the farface, in place of fome of the old earth (a hand-depth or 60 ) and loufning the reft with a fork without wounding the Roots : let this be of excellentrich fcil, fuch as is throughly confum'd arid will fift, that it may wash in the verrue, and comfort the Plant: Brugh, and cleanfe them likewife from the draft contracted during their Enclofure: Tbefe two lift direaions bave till now been kept as confiderable Secrets umiongf our Gard'ners: vide Augujt and Siptember.

Shade your Carnations and Gilly-flwwers after mid-day about this Sedfon : Plant alfo your Stock-gilly-flowers in beds, full Moon.

Gather what Anemonj--eed you find ripe, and that is worth faving, preferving it very dry.

Cut likewife the Stalks of fuch Bulbous-flowers as you find dry.

Towards the end take up thofe Tulips which are dri'd in the ftalk; covering what you find tolie bare from the Sun and fhowsers.

\section{Flowers in Prime, or yet lafing.}

T Ate fet Anemonies and Ranunculus omn.gen. Anapodophylon, Chame-iris Anguitifol.Cyanis, 1 Columbines, Caltha palwfris, double Cotyledon, Digitatis, Fraxinella, Gladiolus, Geraniam, Horminum Creticum, yellow Hemerocallis, frip'd Facynth, early Bulbous Iris, Aßphodel, yellow Lilies, Lycbnis, Facea, Bellis double, white and red, Millefolium luteum, Lilium Convallium, Span.pinkes, Depiford-tin'e, Rofa common, Cinnamon, Guelder and Contifol. \&c. Syriaga's, Sedum's, Tulips Serotin, \&xc. Valerian, Veronica double and fingle, Musk.Violets, tadies Slipper, Stuck-gilly-flwwers, Spanifh Nut, Star-flower, Chalcedons, ordinary Crowo-foot, red Marragon, Bee-finaters, Campinula's white and blew, Perfian Lilly, Hony-fuckles, Buglodfe, Hod mers Moly, and the white of Dinfcorides, P.nfys, Prunella, purple Thaliefrum, Sifymbrium double and fimple, Leucoium bulbofum ferotinum, Rofi-mary, Stacbas, Barba Jovis, Lauras, Satyrion Oxyacantbus, Tamarifcus, Appli-bloffoms, \&cc. 
$\operatorname{Sun}\left\{\begin{array}{l}\text { rifes-0 }-03^{2}-5^{\mathrm{m}} \\ \text { fets }-08-09\end{array}\right\}$

9

\section{JUNE}

$$
\left\{\begin{array}{l}
\text { Hath Days } \\
x_{x \times}, y_{0}
\end{array}\right\}
$$

\section{To be done}

\section{In the Orchard, and Olitory-Garden.}

SOw Lettuce, Chervil, Radifl, \&uc. to have young, and tender Salleting. D About the midlft of June you may Inoculate Peaches, Abricots, Cherries, Plums, Apples, Pears, \&c:

You may now alfo (or before) cleanfe Vines of exuberant branches and tendrels, cropping (not cutting) and ftopping the joynt immediately before the Bloffome, and fome of the under branches which bear no fruit; efpecial$1 y$ in young Vineyards when they firt begin to bear, and thence forwards.

Gather Herbs in the Full, to keep dry; they keep and retain their virtue, and fweet $\int m e l l$, better $d r y^{2} d$ in the Sun, then Bade, whatever fome pretend.

Now is your Seafon to diftill Aromatic Plants, ${ }^{\circ}$ cr.

Water lately planted Trees, and put moint, and half rotten Fearn, orc. about the foot of their Stems.

Look to your Bees for $S$ warms, and Cafts; and begin to deftroy Infects with Hoofes, Canes, and tempting baits, \&uc, Gather Snails after Rain, out.

\section{Fruits in Prime, or yet lafting.}

Apples.

Uniting (firt ripe) Pepins, Fobn-apples, Robillard, Red-Fennouil, Euc. French

The Maudlin (firft ripe) Madera, Green-Royal, St. Laurence-pear, Evc.

Duke, Flanders, Heart $\left\{\begin{array}{l}\text { Black. } \\ \text { Red. } \\ \text { White. }\end{array}\right.$

Cherries, ouc.

Luke-ward; carly Flanders, the Common-cherry, Spanifh-black, Naples Cherrics, \& c.

Rasberries, Corinths, Straw-berries, Melons, \&c. 
KALENDARIUM HORTENSE.

Sun $\left\{\begin{array}{l}\text { rifes- }-03^{\mathrm{h}}-57^{\mathrm{m}} \\ \text { fets }-08-09\end{array}\right\}$
5

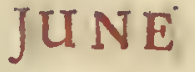

$\left\{\begin{array}{l}\text { Hath Days } \\ x x x .\end{array}\right\}$ long-16t-1 $7^{\text {th }}$

To be done

In the Parterire, and Flower-Garden.

$T$ Ranfplant Autumnal cyclamens now if you would change their placè; otherwife let them ftand.

Gather the ripe feeds of Flowers worth the faving, as of choiceft Oriental Jacynth, Narcifjics (the twoleffer, pale fpurious Daffodels of a whitith green, often produce varieties) Auriculas, Ranunculus's, Ouc. and preferve them dry : Shade your Carnations from the afternoons Sun.

Take up your rareft Anemonies, and Ranunculus's after rain (if it come feafonable) the ftalk wither'd, and dry the roots well : 'This about the cnd of the monetb: In mid Fune Inoculate Fafmine, Rofes, and fome other rare forubs. Sow now alfo fome Anemony feeds. Take up your Tulip-bulbs, burying fuch immediately as you find naked upon your beds; or elfe plant then in fome cooler place; and refrefh over parched beds with water: Plant your Narcifjus of Japan (that rare flower) in Pots, \&c. Allo may you now take up all fuch Plants and Flower-roots as endure not well out of the ground, and replant them again immediately: fuch as the early Cyclamen, Facynth oriental, and other bulbous Facynths, Iris, Fritillaria, Crown-Imperial, Martagon, Mufcaris, Dens Caninus, \&c. The flips of Myrtil fet in fome cool and moift place do now frequently take root: Alfo Cytifus lunatus will be multiplied by llips; fuch as are an bandfullong of that Spring. Look now to your Aviary; for now the Birds grow fock of their Featbers; therefore affift them with Emulfions of the cooler feeds bruis'd in their water, as Melons, Cucumbers, \& c. Alfo give them succory, Beets, Groundfell, Cbick-weed, \&c.

\section{Flowers in Prime, or yet lafting.}

A Maranthus, Antirrbinum, Campanulla, Clematis.Pannonica, Cyanss, Di gitalis, Geranium, Horminum Creticum, Hieracium, bulbous Iris, and divers others, Lyclsnis var. generum, Martagon white and red, Millefolium white and yellow, Nafturtium Indicum, Carnations, Pinks, Ornitbogalum, Panfy, Phalangium Virginianum, Larks-beel carly, Pilofella, Rofes, Thlapi Creticum, \&c. Veronica, Viola pentapbyl. Campions or Sultans, Mountuin Lilies white, red: double Poppies, stock-gilly-flowers, Jafmines, Corn-flag, Hollyboc, Mufcaria, Serpyllum Citratum, Pbilangium Allobrogicum, Oranges, Rofe-mary, Lentifcus, Pome-Granade, the Linie-tree, \&c: 
Sun $\left\{\begin{array}{l}\text { rifes }-04^{h}-00^{\text {m }} \\ \text { fets }-08--00\end{array}\right\}$

$\Omega$

J U L Y

$\left\{\begin{array}{c}\text { Hath Days } \\ \text { xxxi. }\end{array}\right\}$ long-1 $5^{h}-59^{m}$

To be done

In the Orchard, and Olitory-Garden.

SW Lettuce, Radifh, \&oc. to have tender falleting.

$\checkmark$ Sow later Peafe to be ripe fix weeks after Michaelmas.

Water young planted Tries, and Layers, \&cc. and prune now Abricots, and Peaches, faving as many of the young likelieft fhoots as are well placed; for the now Bearers commonly perifh, the new ones fucceeding: Cut cloje and even.

Let fuch olitory-herbs run to feed as you would fave.

Towards the latter end, vifit your Vineyards again, $\mathcal{C r}_{c}$. and ftop the exuberant /hoots at the fecond joynt above the fruit; but not $\int_{0}$ as to expofe it to the sun.

Now begin to ftreighten the entrance of your Bees a little; and help them to kill their Drones if you obferve too many; fetting Glafes of Beer mingled with Hony to entice the $W a p s$, Flyes, \&uc. which wafte yourftore: Alfo hang Bottles of the fame Mixture neer your Red-Roman-Nectarines, and other tempting fruits, for their deftruction; elfe they many times invade your beft Fruit.

Look now alfo diligently under the leaves of Mural-Trees for the Snails; they ftick commonly fomewhat above the fruit : pull not off what is bitten; for then they will certainly begin a frelh.

\section{Fruits in Prime, or yet lafting.}

Apples.

Eux-ans, Pepins, Winter Ruffeting, Andrew-apples, Cinnamon-apple, red and white Funiting, the Margaret-apple, \&ce.

Pears.

The Primat, Ruffet-pears, Summer-pears, green Chefll-pears, Pearl-pear, \&c.

Cherrics.

Carnations, Morella, Great-bearer, Moorocco-cherry, the Egriot, Bigarreaux, \&c. Peaches.

Nutmeg, Ifabella, Perfian, Newington, Violet-mufcat, Rambouillet.

Plums, \&cc.

Primordial, Myrobalan, the red, blew, and amber Violet, Damafc. Denny Damafc. Pear-plum, Damafc. Violet, or Chefon-plum, Abricot-plum, Cinnamon-plum, the Kings-plum, Spanijh, Morocco-plum, Lady Eliz. Plum, Tawny, Damafcene, \&xc. Rasberries, Goofe-berries, Corinths, Straw-berries, Melons, \&c. 
$\Omega$

$\operatorname{Sun}\left\{\begin{array}{l}\text { rifes }-04^{h}-00^{m} \\ \text { rets }-08-00^{\circ}\end{array}\right\}$

\section{JULY}

$\left\{\begin{array}{l}\text { Hath Days } \\ \text { xxxi. - }\end{array}\right\}$ long-15 $15^{\mathrm{b}}-59^{\mathrm{m}}$

\section{To be done}

\section{In the Parterre, and Flower-Garden.}

SLip Stncks, and other lignous Plants and Flowers : From henceforth to Micbaelmas you may $S$ alro lay Gilly-flowers and (ariations for Increafe, leaving not above two, or three pindles for flowers, with fupports, cradles and boofes, to eftablifh them againit winds, and deftroy Earwigs.

The Layers will (in a moneth or $f(x$ weeks) ftrike root, being planted in a light loamy earth mix'd with excellent rottein foil and fiefted: plant fix or eight in a pot to fave room in Winter: keep them well from too much Rains : But sade thofe which blow from the afternoons Sun, as in the former Moneths.

Yet alfo you may lay Myrits, and other curious Greens.

Water young planted S Shrubs and Layers; $\sigma_{c} c$. as Orange-trees, Myrtils, Granads, Amomum, orc. clip Box, \&c. in Parterrcs, Knots, and Compartiments, if need be, and that it grow out of order; do it after Rain.

Graff by Approach, Inarcib or Inoculate 7 afmines, Oranges; and other your choicett Armbs.

Take up your early autumnal Cyclamen, Tulips and Bulbs (if you will Kemove them, ¿vc.) before mention'd; Tranßlanting them immediatcly; or a Monetb after if you pleafe, and then cutting off, and trimming the fibres, fpread them to Air-in fone dry place.

Gather now alfo your early Cyclamicn-feeds, and fow it prefently in Pots.

Likewife you may take up fone Anemonies, Ranunculus's, Crocus, Cronn Imperial, Perfian Iris, Fritillaria, and Colcbicums, but plant the three laft as foon as you have taken them up, as you did the Cyclamens.

Remove now Dens Caninus, oc.

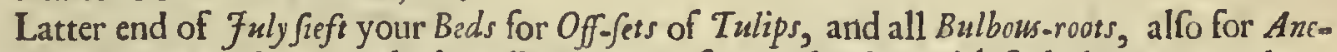
monies, Ranunculu's, 6 c. which will prepare it for re-planting with fuch things as you have ready in pots to plunge, or fet in naked earth till the next feafon; as Amurantbs, Canna Ind. Mirabile Peruv. Capficum Ind. Nafturt.Ind.\&c. that they may not lie empty, and dil-furnilh'd.

Continue to cut of the wither'd falks of your lower fowers, \&c. and all others, covering with earth the bared roots, oc.

Now (in the drieft feafon) with Brine, Pst-afbes and or a decocition of Trbacco refue, water your Gravel-malks, $\sigma_{c}$. to deftroy both $W$ orms and $W_{\text {ecds, }}$ of which it will cure them for fome years.

\section{Flowers in Prime, or yet lafting.}

A Maranibus, Campanula, Clematis, Sultana, Veronica purple and odoriferous; Digitali, A Eryngium Planum, Ind.Pbajenlus, Geranium trifte, and Creticum, Lycbnis Cbalcadon. Facea white and double, Nafturt. Ind. Millefolium, Musk-role, Flos Africanus, Thlap $\sqrt{2}$ Creticum, Veronica mag. \& parva, Volubilis, Baljan-apple, Holj-bock, Snapdragon, Corn-fle. Alkekengi, Lupines, Scorpion-graß, Carynpbyllata om. gen. Stock-gilly-flo. Indian Tuberous Facynth, Limonium, Linaria Cretica, Panfi , Prunclla, Delpbinium, Pbalanyium, PeriplocaVirgin. Flos Pafionis, Flos Cardinalis, Oranges, Amomrm Plinii, Oleanders red and white, Agnus Caftus, Arbutus, rucca, Olive, Liguftrum, Tilia, \&c. 
$\operatorname{Sun}\left\{\begin{array}{l}\text { rifes- }-04^{h}-43^{m} \\ \text { fets }-07-17\end{array}\right\}$

\author{
me \\ AUGUST
}

\section{To be done}

\section{In the Orchard, and Olitory-Garden.}

Noculate now early, if before you began not.

1 Prune off yet alfo fuperfluous Brancbes, and ßhoots of this Second ßpring; but be careful not to expofe the fruit, without leaves fufficient to skreen it from the Sun; furnifhing, and nailing up what you will rpare to cover the defects of your Walls. Pull up the $S$ usckers.

Sow Raddifh, tender Cabages, Cauly-flowers for Winter Plants, Corn-fallet, Marygolds, Letuce, Carrots, Parfneps, Turneps, Spinage, Onions; allo curl'd Endive, Angelica, Scurvy-grafs, oc. Likewife now pull up ripe Onions and Garlic, $\&$ c.

Towards the end fow Purlan, Chard-Beet, Chervile, foc.

Tranplant fuch $L$ etuce as you will have abide all $W$ inter.

Gather your Olitory Seeds, and clip and cut all fuch Herbs and Plants within one bandful of the ground before the full. Laftly,

$V_{n b i n d}$ and releafe the Buds you inoculated if taken, orc.

Now vindemiate and take your Bees towards the expiration of this Monetb; unlefs you fee caufe (by reafon of the Weatber and Seafon) to defer it till mid-September: But if your Stocks be very light and weak, begin the earlier.

Make your Summer Perry and Cider.

\section{Fruits in Prime, or yct lafting.}

Apples.

$T$ He Ladies Lonying, the Kirkham Apple, Fobn Apple; the Seaming Apple, Cughion Apple, 1 Spicing, May-finwer, Sheeps fnout.

Pears.

- Iindfor, Soveraign, Orange, Bergamot, Slipper Pear, Red Catberine, King Catberine, Denny Pear, Prufia Pear, Summer Poppering, Sugar Pear, Lording Pear,

Peaches.

Roman Peach, Man Peach, 2uince Peach, Rambnuillet, Musk Peach, Grand Carnation, poraugal Peach, Crozon Peach, Bourdeaux Peach, Lavar Peach, the Peach De-Spot, Savoy Malacoton, which lafts till Micbaelmus, $6 c$.

Nectarines.

The Muroy Nectarine, Tawny, Red-Koman, little Green Nectarine, Clufter Nectarine, $X_{\varepsilon l-}$ low NeEtarine.

Plums.

Imperial, Blew, White Dates, Yellow Pear-plum, Black Pear-plum, White Nutmeg, late Pear-plum, Great Antbony, Turkey Plım, the Fane Plum.

Other Fruit.

Cluffcr-grape, Mufcadine, Corinths, Corneli..ns, Mulberies, Figs, Filberts, Melons, †c. 
$\operatorname{Sun}\left\{\begin{array}{l}\text { rifes- }-04^{\mathrm{a}}-43^{\mathrm{m}} \\ \text { fets-0 }-07-17\end{array}\right\}$ nt

\section{AUGUS T}

\section{To be done}

\section{In the Parterre, and Flower-Garden.}

TOw (and not till non if you expect fuccefs) is the juft Seafon for the bndding of the Orange Tree: Inoculate therefore at the commencement of this Monetb.

Now likewife take up your bulbous Iris's ; or you may fow their $\int e e d s$, as alfo thofe of Larksbeel, Candi-tufis; Columbines, Iron-colour'd Fox-gloves, Holly-bocks, and fuch Plants as endure Winter, and the approaching Seafons.

Plant fome Anemony roots to have flowers all $W$ inter, if the roots efcape.

You may now fow Narcifas, and Oriental Facynths, and re-plant fuch as will not do well out of the Eartb, as Fritillaria, Iris, Hy,acinths, Martagon, Dens Caninus.

Gilly-flowers may yet be flipp'd.

Continue your taking up of $B u l b s$, Lilies, \&c. of which before.

Gatber from day to day your Alaternus feed as it grows black and ripe, and fpread it to froeat and dry before you put it up; therefore move it lometimes with a broom that the feed's clog not together.

Moft other Seeds may now likewife be gathered from Srubs, which you find ripe.

About mid-Aug. tranfplant Atricula's, dividing old and lufty roots; alfo prick out your Seedlings: They beft like a loamy fand, or light moift Earth.

Now you may fow Anemony feeds, Ranunculus's, \&c. lightly cover'd with fit mould in $C_{a}$ Jes, thaded, and frequently refrefh'd: Allo Cyclamen, Facynths, Iris, Hepatica, Primrofes, Fritillaria, Martagon, Fraxinella, Tulips, orc. but with patience; for fome of them, becaufe they flower not till three, four, five, fix, and feven years after, efpecially the Iulips, therefore difturb not their beds, and let them be under fome warm place, fhaded yet, till the beats are paft, left the Seeds dry; only the Hepaticas, and Primerofes may be fow'd in fome lefs expos'd Beds.

Now, about $B$ irtholomew-tide, is the only fecure feafon for removing and lazing your perennial Greens, Oranges, Lemmons, Myrtils, Philyreas, Oleanders, 7 afmines, Arbutus, and other rare Shrubs, as Pome-granads, Rofes, and whatever is moft obnoxious to frofts, taking the Aronts and branebes of the paft Spring and pegging them down in very ricb earth and foil perfeitly confum'd, water them upon all occafions during the Ssummer; and by this time trelvemonetb they will be ready to remove, Iranfplanesd in fit earth, fet in the Shade, and kept moderately moift, not over wer, left the young fibers rot; after three weeks fet them in fome more airy place, but not in the $S$ un till fifteen days more; Vide our Obfervations in April, and May", for the reft of thefe choice Directions.

\section{Flowers in Prime, or yet lafting.}

A Marantbus, Anagallis Lufitanica, After Atticus, Blattaria, Spanifh Belis, Beliedere, CamA panula, Clematis, Cyclamen Vernum, Datura Turcica, Eliocbryfon, Eryngium planum \&o Ametbyftinum, Geranium Creticum, and Trifte, Yellow Stocks, Hicracion minus Alpeftre, Tuberofe Hyacinch, Limonium, Linaria Cretica, Lychnis, Mirabile Peruvian. Yellow Mill fol. Nafturt. Ind. Yellow mountain Hearts-eafe, Maracoc, Africanus fos, Convolvulus's, Scabieus, Aphodils, Lupines, Colchicum, Leucoion, Autumnal Hyacinth, Holly-boc, Star-wort, Heliotrop, French Mary-gold, Daifies, Geranium nocie olens, Common Panfies, Larks-beels uf all colours, Nigella, Lobells Catch-fi, I blapi Creticum, Rofemary, Mask-Rofe, Monetbly Roje, Olcanders, Spanißh Fafmine, Yellow Indian $\mathrm{F}$ afmine, Myrtils, Oranges, Pome-granads double, and fingle flowers, Agnus Caftus, \%c。 


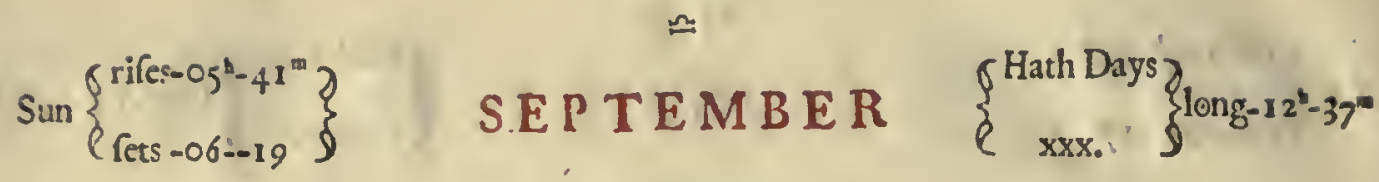

To be done

In the Orchard, and Olitory-Garden.

Ather now (if ripe) your Winter Fruits, as Apples, Pears, Plums, Ouc. to

I prevent their falling by the great Winds: Alfo gather your Wind-falls from day to day : do this work in dry weather.

Sow Lettuce, Radijh, Spinage, Parfneps, skirrets, \&c. Cauly-fowers, Cabbages, Onions, \&c. Scurvy-graß, Anif-feeds, \&x.

Now may you Tranjplant moft forts of Efculent, or Pbyfical plants, duc.

Alfo Artichocks, and Aparagus-roots.

Sow alfo Winter Herbs and Roots, and plant Straw-berries out of the Woods.

Towards the end, earth up your Winter Plants and Sallad berbs; and plant forth your Cauly-flowers and Cabbages which were fown in Auguft.

No longer now defer the taking of your Bees, ftreightning the entrances of fuch Hives as you leave to a fmall paffage, and continue fill your boftility againft $W$ aps, and other robbing Infects.

cider-making continues:

\section{Fruits in Prime, or yet lafting.}

Apples.

THe Belle-bonne, the William, Summer Pearmain, Lording-apple, Fearapple, 2uince-apple, Red-greening ribb ${ }^{\circ} d$, Bloody-Pepin, Harvey, Violetapple, \&c.

\section{Pears.}

Hamdens Bergamot, (firft ripe) Summer Bon Chreftien, Norwich, Black. Worce. Jter, (baking) Green-field, Orange, Berganot, the Queen hedge-pear, Lemes-pear (to dry excellent) Frith-pear, Arundel-pear (afo to bake) Brunfmick-pear, winter Poppering, Bings-pear, Bifhops-pear, (baking) Diego, Emperours-pear, Clufter-pear, Melfire Fean, Romling-pear, Balfam-pear, Bezy d'Hery, \&c.

Peaches, \&uc.

Malacoton, and fome others, if the year prove backwards, Almonds, \&c.

Quinces.

Little Blew-grape, Mufcadine-grape, Frontiniac, Parfey, great Blew-grape, the Verjuyce-grape excellent for fauce, \&uc.

Berberries, \&c. 


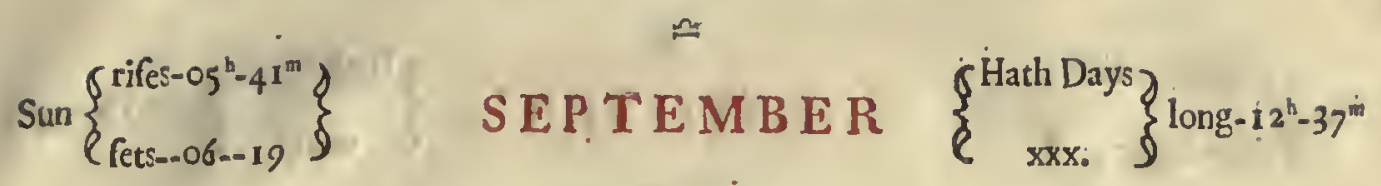

\section{To be done}

\section{In the Parterre and Flower-Garden.}

P Lant fome of all the forts of Anemonies after the firft Rains, if you will have flowers very forwards; but it is furer to attend till OEtober, or the Monetb after, left the over moifture of the Autumal feafons give you caufe to repent.

Begin now alfo to plant fome Tulips, unlers you will ftay till the later end of Odober, to prevent all hazard of rotting the Bulbs.

All Fibrous Plants, fuch as Hepatica, Hellebor, Cammomile, of. Alfo the Cupillaries; Matricaria, Violets, Prim-rofes, \&c, may now be tranßplanted.

Now you may alfo continue to fow Alaternus, Pbilyrea (or you may forbear till the Spring) Iris, Crown Imper: Martagon, Tulips, Delphinium, Nigella, Cands-tufts, Poppy; and generally all the Annuals which are not impair'd by the Frofts.

Your Tuberojes will not endure the wet of this Seafon; therefore fet the Pots into your Conferve, and keep them very $d r y$.

Bind now up your Autumnal Flowers, and Plants to ftakes, to prevent fudden Gufts which will elfe proftrate all you have fo induftriouly rais'd.

About Michaelmas (forner, or later, as the Seafon direets) the weather fair, and by no means foggy, retire your choice Grcens, and rareft Plants (being dry) as Oranges, Lemmons, Indian, and Span. Fafmine, Oleanders, Barba-Fovis, Amomum Plin. Cityys Lunatus, Chamelea tricoccos, Ciftur Ledon Clufij, Dates, Aloes, Sedum's, \& c.into your Confervatory; ordering them with frefh mould, as you were taught in May, viz. taking away fome of the upmoft exbarrfed earth, and firring up the reft, fill the Cafes with rich, and well confum'd foil, to waih in, and nourifh the Roots during $W$ inter; but as yet leaving the deors and windews open, and giving them much Air, fo the Winds be not tharp, nor weather foggy; do thus till the cold being more intenfe advertife you to enclofe them all together: Myrtils will endure abroad neer a Monetb longer.

The cold now advancing, fet fuch plaxts as will not endure the Houfe into the earrb; the pots two or three incbes lower then the furface of fome bed under a Soutbern expofure: Then cover them with gla Jes, having cloath'd them firft with fweet and dry Moß; but upon all toarm, and benigne emiffons of the Sun, and fweet fhowers, giving them air, by taking off all that covers them : Thus you thall preferve your coftly and precions Marum Syriacum, Cifru's, Geranium nodie olens, Flos Cardinalis, Maracocs, feedling Arbutus's (a very hardy plant when greater) choicelt Ranunculus's and Anemonies, Acacia \#kgyt. \&c. Thus governing them till April. Secrets not till now divulg'd.

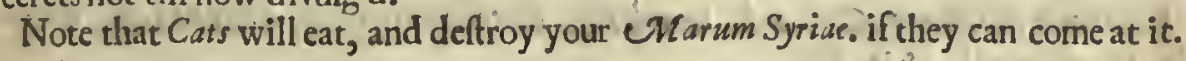

\section{Flowers in Prime, or yet lafting.}

A Muranthustricolor, and others; Anagallis of Portugal; Antirrbinum, African flo. Amomum A Plinii, After Atticus, Belvedere, Bellis, Campanilla's, Colchicum, Antumnal Cyclaman, Chryfanthemum anyuftifol. Eupatorium of Canada, Sun-flumer, Stock.gill. flo. Geranium Creticum, and nocte olens, Gentianella annual, Hieracion minus Alpeftre, Tuberous Indian Facynth, Linaria Cretica, Lychnis Conftant. fingle and double; Limonium, Indian Lilly Narciff. Pomum Aureum, and Amoris, \& Spinofum Ind. Marvel of Peru, Mille-folium yellow, Nurfturtium Indicum, Perfian autumnal Narcifus, Virginian Pbalanyium, Indian Pbafiölus, Scarlet Beans, Convolvulus diverf.gen. Candy Tufts, Veronica, purple Volubilis, Aphodill. Crocus, Garnfey Lily, or Narcifus of Japan, Popty of all colours, fingle, and double, Malva arborcfcens, Indian Pinks, Etbiopic Apples, Capficum Ind. Gilly-flowers, Paffion-flower, Doture double and fing. Portugal Ranunculus's, Spanifh $\mathrm{F}$ afmine, yellow Virginisn $\mathrm{F}$ afmine, Rbododendron white and red, Oranges, Myritls, Muske Rofe, and Monethly Rife, \&c. 
$\operatorname{Sin}\left\{\begin{array}{l}\text { rifes-06t-26m } \\ \text { ects--05-24 }\end{array}\right\}$

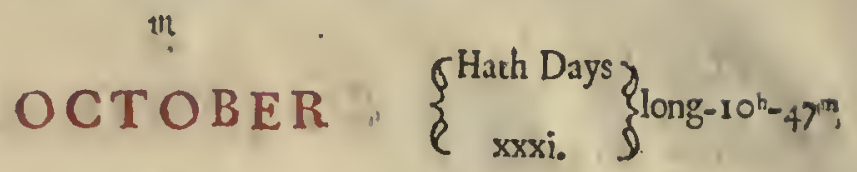

To be done

\section{In the Orchard, and Olitory-Garden.}

7 Rench Grounds for Orcharding, and the Kitchin-garden, to lye for a Win1 ter mellowing.

Plant dry Trees (i.) Fruit of all forts, standard, Mural, or Shrubs which lofe their leafe; and that fo foon as it falls: But be fure you chufe no Trees for the $W$ all of above two years Graffing at the moft.

Now is the time for Ablaqueation, and laying bare the Roots of old unthriving, or over bafty blooming trees.

Moon now decreafing, gather Winter-fruit that remains, weather dry;take heed of bruifing, lay them up clean left they taint, Cut and prune Rofes yearly.

Plant and Plalh Quick-fets.

Sow all ftony, and hard kernels and feeds, fuch as Cherry, Pear-plum, Peach, Almond-ftones, Euc. Alfo Nuts, Haw.s, Ahen, sycomor and Maple keys; Acorns, Beech-mast, Apple, Pear and Crabkernels, for Stocks; or you may defer it till the next Monet b towards the later end.

You may yet fow Letuce.

Make Winter Cider, and Perry.

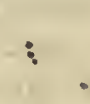

\section{Fruits in Prime, or yet lafting.}

Apples.

$\mathrm{B}^{\text {Elle-et-Bonne,William, Coftard, Lording, Parfley-apples, Pearmain, Pear- }}$ apple, Hony-meal, Apis, \&c.

\section{Pears.}

The Caw-pear (baking) Green-butter-pear, Thorn-pear, Clove-pear, Rouffelpear, Lombart-pear, Ruffet-pear, Suffron-pear, and fome of the former Moneth. Bullis, and divers of the September Plums and Grapes, Pines, \&c. 
in

$\operatorname{Sun}\left\{\begin{array}{l}\text { rifes-06 } 6^{\mathrm{h}}-26^{\mathrm{m}} \\ \text { [ets }-05^{-2} 4\end{array}\right\}$

OCTOBER

$\left\{\begin{array}{l}\text { Hath Days } \\ \text { sxxi. }\end{array}\right\}^{\text {long-10 }}$ h $-47^{\text {tक }}$

\section{To be done}

\section{In the Parterre, and Flower-Garden.}

TOw your Hyacinthus Tuberofe not enduring the soet, muft be fet into the boufe, and pre1 ferved very dry till April.

Continue fowing what you did in Sept. if you pleare: Alfo,

Youmay plant fome Anemonies, and Ranuncnlus's, in freth fandifisearth, taken from under the turf; but lay richer mould at the bottom of the bed, which the fibres may reach, but not rouch the main roots, which are to be cover'd with the natural earth two inches deep: and fo foon as they appear, fecure them with Mats, or $S t$ raw, from the winds and frofts, giving them air in all benigne intervals; if poflible once a day.

Plant alro Ranunculus's of Tripoly, \&sc.

Plant now your choice Tulips, $\delta r_{c}$. which you feared to interre at the beginning of Septem. ber; they will be more fecure, and forward enough : but plant them in natural earth fomewhat impoierifh'd with very fine faxd; elfe they will foon lofe their variegations; fome more rich earth may lye at the bottom, within reach of the fibres: Now have a care your Carnations catch nut too much ivet; therefore retire them to covert, where they may be kept from the rain, not the air, rrimming them with frefb morld.

All forts of Bulbous roots may now alfo be fafely buried ; likewife Iris's, occ..

You may yet fow Alaternis, and Pbilyrea feeds: It will now be good to Beat, Roll, and Mow Carpet-walks, and Camomile; for now the ground is $\int u p p l e$, and it will $\epsilon$ ven all ine qualities : Finih your lait $W$ eeding,

Sweep and cleanfe your $W$ alks, and all other places, of Autumnal leaves fallen, left the Worms draw them into their boles, and foul your Gardens, of $c$ :

\section{Flowers in Prime, or yet lafting.}

A Marantbus tricolor, \&c. After Atticus, Amomum, Antirrbinum, Colcbicum, Heliotrops; A Stock-Gilly.flo. Geranium trifte, Ind. Tuberofe Facynbh; Limonium, Lychnis white and double, Pomum Amoris and Etbiop. Marvel of Peru, Millefol. Luteum, Autumnal Narciff. Panfies, Aleppo Narciff.Spherical Narciff. Nafturt. Perficum, Gilly-flo. Virgin. Phalangium, Pilofells, Violets, Veronica, Arbutus; Span. Fafmine, Oranges; \&c. 
$\operatorname{Sun}\left\{\begin{array}{l}\text { riles-07th }-34^{m} \\ \text { rets-0.04-26 }\end{array}\right\}$

NOVEMBER

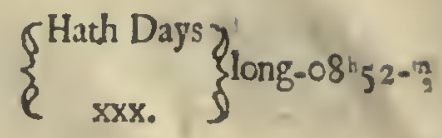

To be done

In the Orchard, and Olitory-Garden.

CArry Compost out of your Melon-gronind, or turn and mingle it with the earth, and lay it in Ridges ready for the spring : Alfo trench and fit ground for Artichocks, \&oc.

Continue your Setting and Tranplanting of Trees; lofe no time, hard Frofts come on apace : Yet you may lay bare old Roots.

Plant young Trees Standards or Mural.

Furnifh your Nurfery with stocks to graff on the following year.

Som and fet early Beans and Peafe till shrove-tide; and now lay up in your Cellars for Seed, to be tranßlanted at Spring, Carrots, Parnneps, Turneps, Cabbages, Cauly-flowers, \&c.

Cut off the tops of -Aparagus, and cover it with long-dung, or make Beds to plant in spring, ofc.

Now, in a dry day, gather your laft orchard-fruits.

Take up your Potatos for Winter fpending, there will enough remain for ftock, though never fo exactly gather'd.

\section{Fruits in Prime, or yet lafting. \\ Apples.}

THe Belle-bonne, the William, Summer Pearmain, Lording-apple, Pear-apple, Cardinal, Winter Cheß-nut, short-ftart, \&uc. and fome others of the former two laft Monetbs, \&oc.

\section{Pears.}

Meljire Fean, Lord-pear, long Bergamot,Warden, (to bake) Burnt Cat, sugarpear, Lady-pear, Icc-pear, Dove-pear, Deadmans-pear, Winter Bergamot, Bellpear, \&c.

Bullis, Medlars, Services. 
7

$\operatorname{Sun}\left\{\begin{array}{l}\text { rifes-0 } 07^{\mathrm{h}}-34^{\mathrm{m}} \\ \text { rets- }-04--26\end{array}\right\}$

NOVEMBER

$\sum_{\text {xixx. }}^{\text {Hath Days }}\left\{\begin{array}{l}\text { long. } 08^{h}-52^{m} \\ \underbrace{m}\end{array}\right.$

To be done

In the Parterre, and Flower-Gardeit.

SOw Auricula feeds thus; prepare very rich earth, more then half dung, $S$ upon that fleft fome very light fandy mould; and then fors: fet your Cafes or Pans in the Sun till March.

Cover your peeping Rainunculus's, \&rc.

Now is your beft feafon (the weather open) to plant your faireft Tulips in places of fhelter, and under Efpaliers; but let not your earth be too rich, vide octob. Tranplant ordinary Fafmine, oc.

About the middle of this Moneth (or fooner, if weather require) quite enclofe your tender Plants, and perennial Greens, shrubs, orc. in your confervdtory, fecluding all entrance of cold, and efpecially fharp winds; and if the plants become exceeding dry, and that it do not actually freeze, refrefh them Baringly with qualified water (i.) mingled with a little sheeps, or Cow-dung : If the feafon prove exceeding piercing (which you may know by the freezing of a digh of woater fet for that purpofe in your Green-bonfe) kindle fome charcoals, and then put them in a bole funk a little into the floor about the middle of it: This is the fafeft stove : At all other times, when the air is warm'd by the beants of a fine day, and that the sundarts full upon the boufe fhew them the light; but enclofe them again before the sun be gone off : Note that you muft never give your Aloes, or Sedums one drop of mater during the whole Winter.

Prepare alfo Mattreffes, Boxes, Cafes, Pots, Euc. forfhelter to your tender Plants and seedlings newly fown, if the weather prove very bitter.

Plant Rofes, Althea Frutex, Lilac, Syringas, Cytifur, Peonies, \& c.

Plant alfo Fibrows roots, fpecified in the precedent Moneth.

Sow alfoftony-Seeds mention'd in octob.

Plant all Foreft-trees for Walks, Avenues, and Groves. leaves.

sweep and cleanfe your Garden-walks, and all other places, of Autumnal

Flowers in Prime, or yet lafting. .

Aemonies, Meadow saffron, Antirrbinum, stock-gilly-flo. Bellis, Panfies,
Rofere Carnations, double Violets, Vetonica, spanifh Jafnine, Musk- 
$\operatorname{Sun}\left\{\begin{array}{l}\left.\text { rifes-0 } 08^{\mathrm{h}}-10^{\mathrm{m}}\right\} \\ \text { rets-.03-50. }\end{array}\right\}$

\author{
$v^{\circ}$ \\ DECEMBER \\ $\left\{\begin{array}{l}\text { Hath Days } \\ \text { xxxi. }\end{array}\right\}$
}

To be done

In the Orchard, and Olitory-Garden.

Drune, and Nail Wall-frnit, and standard-trees.

You may now plant Vines, ofc.

Alfo stocks for Graffing, owc.

Sow, as yet, Pomace of Cider-pre]/ings to raife Nurferies; and fet all forts of Kernels, stones, \&uc.

Sow for early Beans and Peafe; but take heed of the Frosts; therefore furcst to defer it till after Christ mas, unlefs the Winter promife very moderate.

All this Msoneth you may continue to Trench Ground, and dung it, to be ready for Bordures, or the planting of Fruit-trees, \&rc.

Now feed your weak stocks.

Turn and refrefs your Autumnal Fruit, left it taint, and open the Windows where it lyes, in a clear and serene day.

Fruits in Prime, and yet lasting.

Apples.

Donfeting, Leatber-coat, Winter Reed, Che $\beta-n u t$ Apple, Great-belly, the Gono-further, or Cats-bead, with fome of the precedent Moneth.

\title{
Pears.
}

The squib-pear, spindle-pear, Virgin, Gafcogne-Bergomot, scarlet-pear, stopple-pear; white, red and trench Wardens (to bake or roft) erc. 
$\operatorname{Sun}\left\{\begin{array}{l}\text { rifes-0 } 8^{\mathrm{b}}-10^{\mathrm{n}} \\ \text { fets }-03-50\end{array}\right\}$

\author{
v \\ DECEMBER \\ $\left\{\begin{array}{l}\text { Hath Days } \\ \text { xxxi. }\end{array}\right\}$
}

To be done

In the Parterre, and Flower-Garden.

A $\mathrm{S}$ in Fanuary, continue your hoftility againft Vermine. zunculus's, Carnations, \&oc.

Be careful now to keep the Doors and Windows of your Confervatories well matted, and guarded from the piercing Air : for your Oranges, $00 \mathrm{c}$. are now put to' the teft : Temper the cold with a few Char-ioal govern'd as directed in November, orc.

Set Bay-berries, Goc. dropping ripe.

Look to your Fountain-pipes, and cover them with frefh and warm Litter out of the stable, a good thickne $\beta$, left the frofts crack them; remember it in time, and the Advice will fave you both trouble and charge.

Flowers in Prime, or yet liffing.

A Nemonies fome, Perfian, and Common winter Cyclamen, Antirrbinum, Black Hellebor, Laurus tinus, fingle Prim-rofes, Stock-gilly-flo. Iris Clufii, snow flowers or drops, Tucca, \&c. 
COr by fnch a Kalendar it is that a Royal Garden, or Plantation may be F contriv'd, according to my Lord Verulam's defign, profingulis Anni Men-: fibus, for every Monetb of the rear.

But becaufe it is in this cold Seafon, that our Gard'ner is chiefly diligent about preferving his more tender, rare, exotic, and coftly slorubs, Plants and Flomers; We have thought fit to add the Catalogue, as it is (much after this fort) collecfed to our hands by the Learned, and Induftrious Doctor Sharrock (though with fome reformation and improvement) of all fuch, as according to their different Natures do require more or les indulgence: And thefe we have difrributed likewife into the three following Clafjes.

\section{CLASSE.}

Being leaft patient of cold, and therefore to be firft fet into the Confervatory, or other ways defended.

A Cacia Agyptiaca, Aloe Anerican. Amaranthus tricolor, Appalatbus Cret. Balfanum, Helichryfon, Cbamelea tricoccos, Nafturtium Indicum, Indiane Narciffus, Ornithogalon Arat. Ind. Phafeol. Capficum Ind. Pomun .Ethiop. Aurewm, spinofum, Summer Sweet Majoran, the two Marum Syriacum, DaClyls, Piftacio's, the great Indian Fig, Lilac flo. alb. Lavendula Multif. Cluf. Cafius Ragufaus flo. alb. Colutea Odorata Cretica, Narciffus Tuberofus, styrax Arbor, \&c.

\section{I. C L A S SE.}

Enduring the fecond degree of cold, and accordingly to be fecur'd in the Confervatory.

A Momum Plinii, Carob, Chamelea Alpeftris, Ciftus Ledon Cluf. Citron, VerA nal Cyclamen, Summer purple Cyclamen, Digitalis Hifpan.Geranium trifte, Hedyfarnm Clypeatum, Apalatbus Creticus, span. Jafmine, Virgin. Fafmine, suza Iris, Facobaa Marina, Alexandrian Laurel, oleanders, Limoniunz elegans, Myr$t y l s$, Oranges, Lentijcus, Levantine tufted Narcifus, Gill. flo. and choiceft Carnations, Pbalangium Creticum, Afratic double and fingle Ranunculus's, Narcifjus of Japan, Cytifus rubra, Canna Indica, Thymus capitatus, Verbena nodi flo. Cretica, \& $\mathrm{xc}$.

\section{I. C L A S S E.}

Which not perifling but in exceffive Colds, are therefore to be last fet in; or rather protected under Mattreffes, and fleighter Coverings, abroad in the Earth, Cafes, Boxes or Pots, \&c.

Arotonum mas. fem. Winter Aconite, Adiantum Verum, Bellis Hißpan.Calceolus Maria, Capparis, Cineraria, Cneorum Mattbioli, Cytifus Maranthe, rub. Lunaius, Eryngium planum totum Caruleum, Fritillaria mont. Genista Hijpan.flo. alb. Pom-Granads, Oriental Facynth, Bulbous Iris, Laurels, Cherry Laurel, Lychnis double white; Matricaria double flo. olives, Pancration, Papaver Jpinociff. Maracoc, Rofe-mary, sifynrichium, Turpenitine-tree, Teucri- 
un mas Titbymal. Myrtifol. Vetonica doub. flo. fingle Violets, Lavender, serpentaria trifol. Gc. Ornithogalon Arab. white and doub. Narciffis of Conftantinople, late Pine-apples, Moly, Perfian Fafmine, opuntia, or the fmaller Indian Fig, Fucca, sefeli AEthiop. Agnus Castus, Malva Arborefcens, Cistus maf. Althea Frutex, sarfaparilla, Cuprefjus, Critbmum marinum, \&uc.

And to the fe might fome others be added; but we conceive them fufficient, and more then (we fear) fome envious and mercinary Gard'ners will thank us for; but they deferve not the name of that Communicative and noble Profeffon: However, this, as a specimen of our Affestion to the publick utility, and in Commiferation of divers bonourable, and Induftrious perfons, whofe Inclination to this innocent Toil has made them fpare no Treafure or Pains for the furniture of their Parterres with variety, the mifcarriage whereof being fometimes univerfal-to the Curious, has made us the more freely to impart both what we have experimentally learn'd by our own obfervations; and from others of undoubted Candor and Ingenuity: But of this we promife a more ample Illuftration as it concerns the intire Art, together with all its Ornaments of $v \sqrt{e}$ and Magnificence, as thefe Endeavours of ours thall find entertainment, and opportunity contribute to the Defign.

F I N I S. 


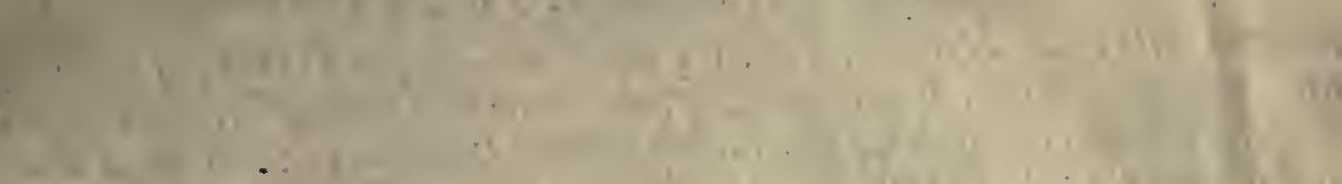
?

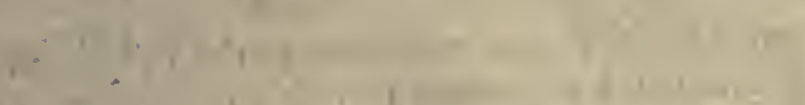

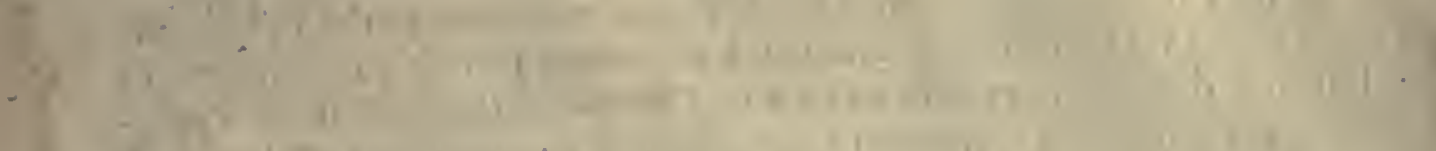
r

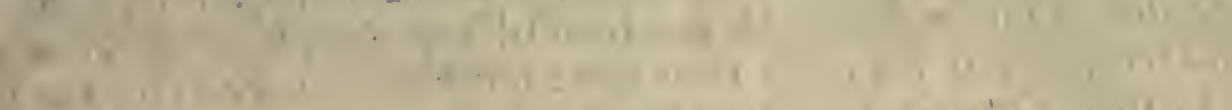

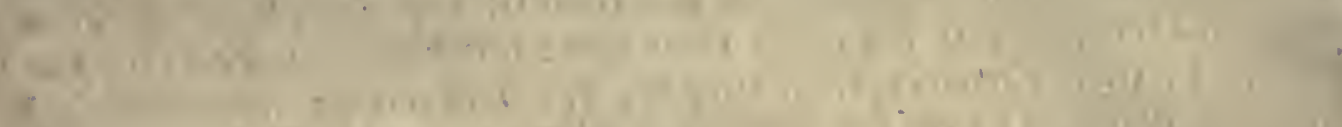

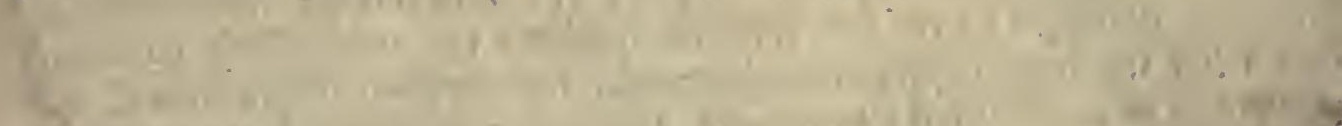

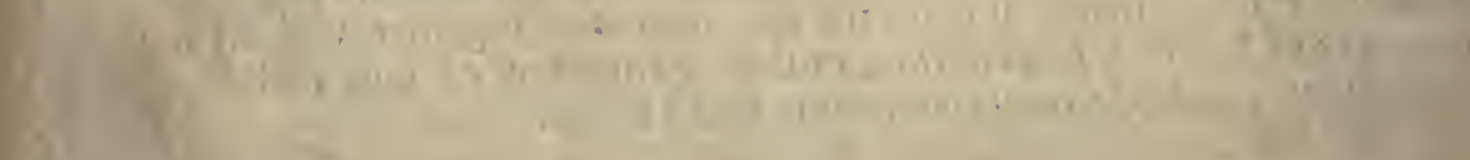

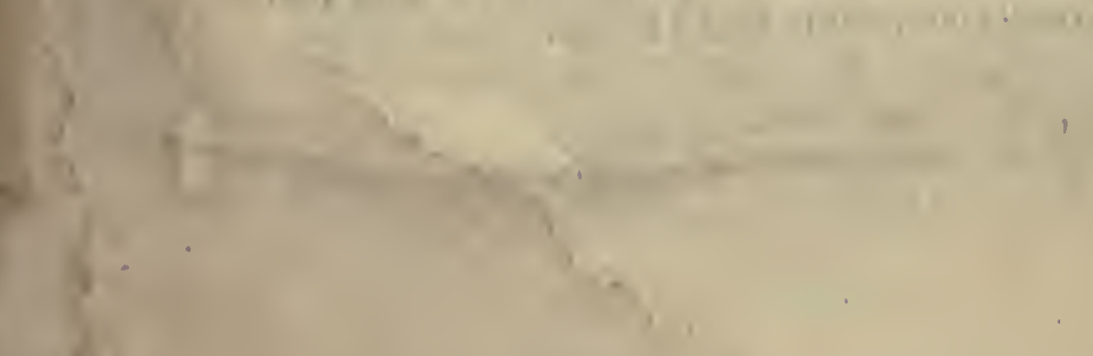

8 


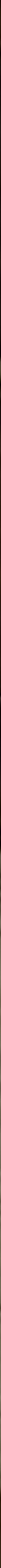




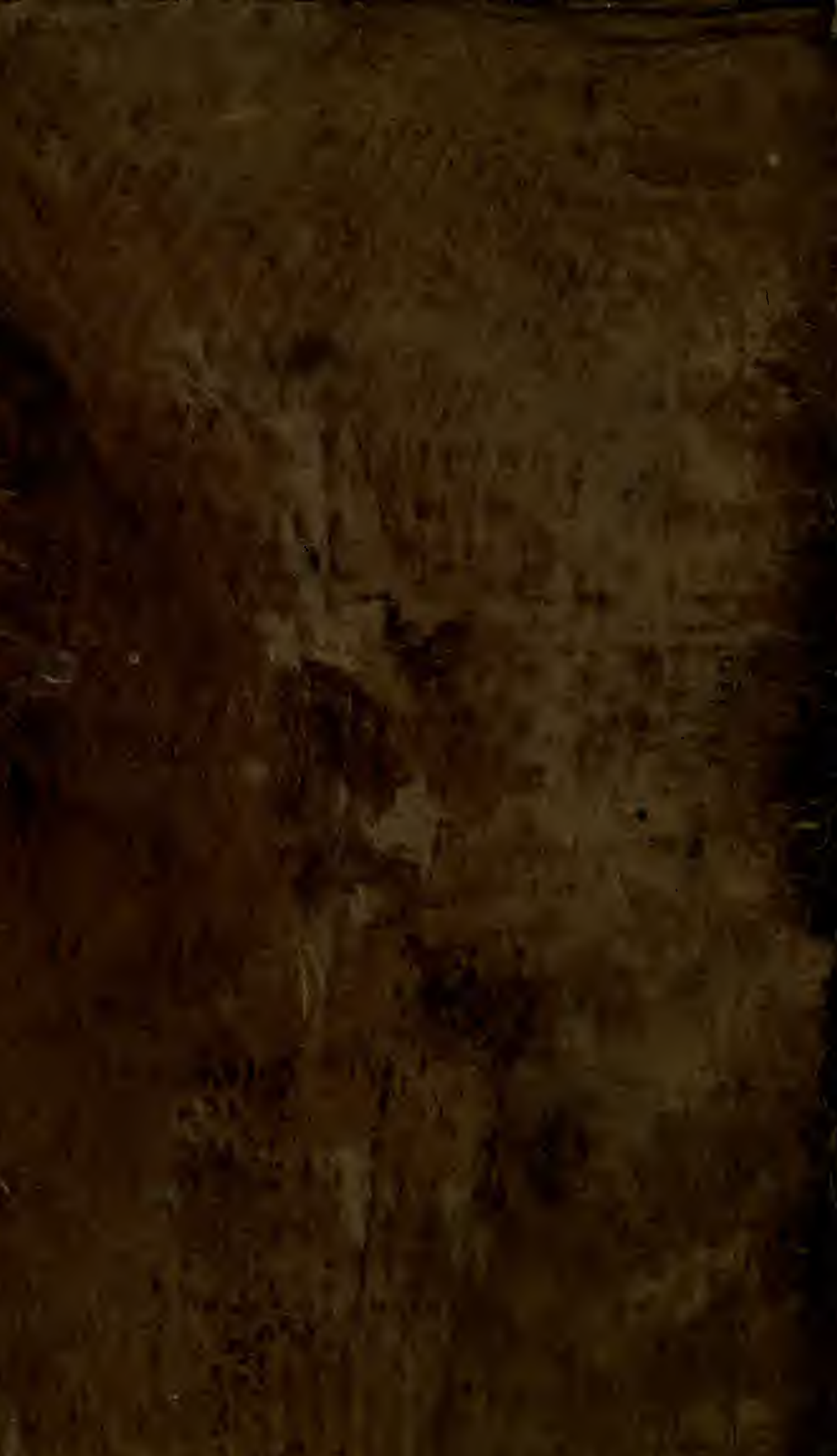

